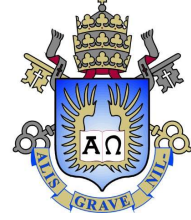

Juan Manuel Girao Sotomayor

\title{
Avaliação do comportamento mecânico drenado e não drenado de rejeitos de minérios de ferro e de ouro reforçados com fibras de polipropileno
}

Tese apresentada como requisito parcial para obtenção do grau de Doutor pelo Programa de Pós-graduação em Engenharia Civil da PUC-Rio.

Orientadora : Profa. Raquel Quadros Velloso Co-Orientadora: Profa ${ }^{a}$ Michéle Dal Toé Casagrande 

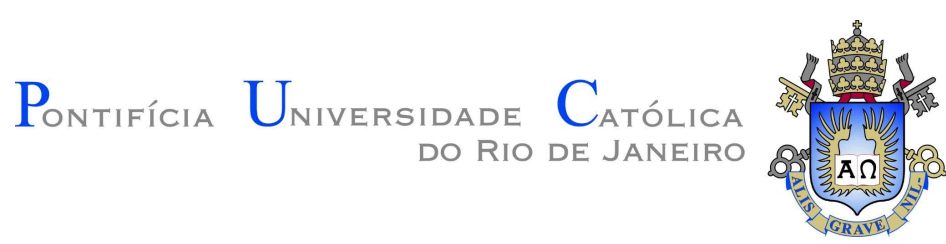

Juan Manuel Girao Sotomayor

Avaliação do comportamento mecânico drenado e não
drenado de rejeitos de minérios de ferro e de ouro
reforçados com fibras de polipropileno

Tese apresentada como requisito parcial para obtenção do grau de Doutor pelo Programa de PósGraduação em Engenharia Civil da PUC-Rio. Aprovada pela Comissão Examinadora abaixo assinada.

Profa. Raquel Quadros Velloso

Orientadora

Departamento de Engenharia Civil e Ambiental - PUC-Rio

Profa ${ }^{a}$ Michéle Dal Toé Casagrande

Co-Orientadora

Universidade de Brasília

Prof. Eurípedes do Amaral Vargas Júnior Departamento de Engenharia Civil e Ambiental - PUC-Rio

Prof. Ben-Hur de Albuquerque e Silva

Departamento de Engenharia Civil e Ambiental - PUC-Rio

Prof. Luis Fernando Martins Ribeiro

Universidade de Brasília

Profa. Sandra Oda

Universidade Federal do Rio de Janeiro

Prof. Márcio da Silveira Carvalho

Coordenador Setorial do

Centro Técnico Científico - PUC-Rio

Rio de Janeiro, 10 de agosto de 2018. 
Todos os direitos reservados. É proibida a reprodução total ou parcial do trabalho sem autorização da universidade, do autor e do orientador.

\section{Juan Manuel Girao Sotomayor}

Graduou-se em Engenharia Civil na Universidade Nacional San Agustín de Arequipa - UNSA, em 2005. Obteve o título de mestre em Engenharia Civil - Geotecnia pela Pontifícia Universidade Católica do Rio de Janeiro - PUC-Rio, em 2014. Principais áreas de interesse e linhas de pesquisas: Mecânica dos Solos, Geotecnia Experimental, Barragens de rejeitos de Minério, Geossintéticos e Novos Materiais Geotécnicos.

Ficha Catalográfica

Girao Sotomayor, Juan Manuel

Avaliação do comportamento mecânico drenado e não drenado de rejeitos de minérios de ferro e de ouro reforçados com fibras de polipropileno / Juan Manuel Girao Sotomayor ; orientadora: Raquel Quadros Velloso ; co-orientadora: Michéle Dal Toé Casagrande. 2018.

184 f: il. color. ; $30 \mathrm{~cm}$

Tese (doutorado)-Pontifícia Universidade Católica do Rio de Janeiro, Departamento de Engenharia Civil e Ambiental, 2018.

Inclui bibliografia

1. Engenharia civil e ambiental - Teses. 2. Rejeitos de minério. 3. Fibras de polipropileno. 4. Comportamento drenado e não drenado. 5. Ensaios triaxiais. I. Velloso, Raquel Quadros. II. Casagrande, Michéle Dal Toé. III. Pontifícia Universidade Católica do Rio de Janeiro. Departamento de Engenharia Civil e Ambiental. IV. Título. 
Para meus pais, Juan e Blanca

Pelo amor, apoio e confiança. 


\section{Agradecimentos}

Primeiro agradeço a Deus, pela vida, pelas lutas e pela oportunidade de conhecer tantas pessoas incríveis durante a realização desta tese.

À minha família, aos meus pais Juan e Blanca, por seu amor, conselhos e principalmente pelas correções, todas as minhas conquistas antes de serem minhas, sempre serão de vocês.

À Laura Yarick por ser minha companheira durante todos estes anos de trabalho, pela paciência, compressão e carinho.

À minha orientadora, Prof ${ }^{\mathrm{a}}$. Michéle Casagrande, pelo constante incentivo, confiança e ensinamentos, compreendíamos o difícil que ia ser o caminho, nunca desistimos e vencemos, obrigado pela oportunidade de trabalhar com você, seu compromisso é um exemplo a seguir. Muito Obrigado!

Aos professores do departamento de Engenharia Civil da PUC-Rio, por todo conhecimento transmitido e aos funcionários em especial: Rita, Marcel, Lenilson e Rafael.

Aos membros da banca examinadora, pela disposição em avaliar e contribuir para a melhoria desta tese.

Aos funcionários dos Laboratórios de Geotecnia e Estruturas: Edson, Amauri, Carlos, Josué, Euclides, Rogério, José Nilson, Sandra e Guaraciara. Obrigado pelo apoio recebido.

À Prof ${ }^{\text {a }}$. Maria Isabel da Silva e o Yuri Nascimento do Departamento de Engenharia Química pelo apoio na realização das análises mineralógicas e de microscopia eletrônica de varredura.

Aos amigos que conheci nesta etapa de doutorado: Mariana Silveira, Fernanda Bernardina, Adriano Malko, Raúl Córdova, John Forero, Mónica Velandia, Leydi Pérez, Abel Arrieta, Rodrigo Tamayo, Sergio Álvarez, Estiven Orozco, Mauricio Céspedes, Carolina Flórez e em especial a os amigos que com música, comida e amizade traziam meu país pro Brasil: Carlos Moreno, Coco Moreno e Jordey Oliveira de Lima.

Ao Javier Gutti e Leo Vera Delgado, pelo apoio logístico dentro e fora da Mineradora, durante os trâmites, recolecção, armazenamento e transporte dos rejeitos de minério desde Peru para a realização desta tese.

À CNPq e à PUC-Rio, pelos auxílios concedidos, sem os quais este trabalho não poderia ter sido realizado. 


\section{Resumo}

Girao Sotomayor, Juan Manuel; Velloso, Raquel Quadros; Casagrande, Michéle Dal Toé. Avaliação do comportamento mecânico drenado e não drenado de rejeitos de minérios de ferro e de ouro reforçados com fibras de polipropileno. Rio de Janeiro, 2018. 184p. Tese de Doutorado Departamento de Engenharia Civil e Ambiental, Pontifícia Universidade Católica do Rio de Janeiro.

O presente trabalho estudou o comportamento de rejeitos de minério de ferro e de ouro, reforçados com fibras de polipropileno, com o objetivo da aplicabilidade destes compósitos em aterros (pilhas) de rejeitos de mineração. As fibras foram distribuídas de forma aleatória nos rejeitos (matriz) em um teor de $0.5 \%$ em relação ao peso seco da matriz. Os rejeitos de minério de ferro e de ouro são classificados como uma areia siltosa e uma argila siltosa, respectivamente. O programa experimental consistiu em ensaios triaxiais convencionais drenados e não drenados (tensões efetivas de confinamento de 50,100, 200 e $400 \mathrm{kPa}$ ) em amostras não reforçados e reforçados com fibras. Ensaios de cisalhamento direto com superfície polida (tensões normais de 25, 50,100, 200 e $400 \mathrm{kPa}$ ) foram realizados para determinar a influência do reforço na fase residual dos compósitos. Ensaios de Microscopia Eletrônica de Varredura (MEV) foram realizados para visualizar a interação fibra-matriz. A análise global dos resultados permitiu mostrar que fibras de polipropileno não modificam o comportamento elastoplástico do rejeito de minério de ferro, porém no rejeito de minério de ouro o comportamento muda para elastoplástico de enrijecimento. A resistência ao cisalhamento incrementou em ambos os rejeitos reforçados, com um ganho mínimo equivalente ao dobro da tensão cisalhante dos rejeitos sem reforço. Com relação à variação volumétrica, o rejeito de minério de ferro apresenta um comportamento dilatante e a adição de fibras incrementa esse comportamento. No rejeito de minério de ouro observa-se que a tendência volumétrica inicial é de contração e depois apresenta uma leve dilatância, porém, com a adição de fibras, o comportamento dilatante é eliminado. Em conclusão, a aplicabilidade das fibras de polipropileno se mostra como alternativa de reforço e melhoria do comportamento geotécnico dos rejeitos de mineração estudados.

\section{Palavras-chave}

Rejeitos de minério de ferro; Rejeitos de minério de ouro; fibras de polipropileno; resistência ao cisalhamento; barragens de rejeito. 


\section{Abstract}

Girao Sotomayor, Juan Manuel; Velloso, Raquel Quadros (Advisor); Casagrande, Michéle Dal Toé (Co-Advisor). Evaluation of drained and non-drained mechanical behavior of iron and gold mine tailings reinforced with polypropylene fibers. Rio de Janeiro, 2018. 184p. Tese de Doutorado - Departamento de Engenharia Civil e Ambiental, Pontifícia Universidade Católica do Rio de Janeiro.

The objective of this work is to study the behavior of iron and gold mine tailings reinforced with polypropylene fibers with the objective of the applicability of these composites in landfills (piles) of mine tailings. The fibers were randomly distributed in the mine tailings (matrix), where was used a content of $0.5 \%$ in relation to the dry weight of the matrix. The iron and gold mine tailings are classified as a silty sand and a silty clay, respectively. The experimental program consisted of conventional drained and undrained triaxial tests (effective confinement stresses of 50,100, 200 and $400 \mathrm{kPa}$ ) in non-reinforced and reinforced samples. Direct shear tests with a polished surface (normal stresses of 25, 50, 100, 200 and $400 \mathrm{kPa}$ ) were performed to determine the influence of reinforcement on the residual phase of the composites. Scanning Electron Microscopy (SEM) tests were performed to visualize the fiber-matrix interaction. The global analysis of the results allowed to show that polypropylene fibers do not modify the elastoplastic behavior of the iron mine tailings, but in the gold mine tailings the behavior changes to the strain-hardening elastoplastic. Shear strength increased in both reinforced tailings, with a minimum gain equivalent to twice the shear stress of non-reinforced tailings. The strength parameters in the drained, undrained and residual condition of both mine tailings were increased with the addition of fiber. Regarding the volumetric variation, the iron mine tailings exhibits a dilative behavior and the fiber addition increases this behavior. In the gold mine tailings, it is observed that the initial volumetric tendency is contractive and then presents a slight dilatancy, however, with the fiber addition, the dilative behavior is eliminated. In conclusion, the applicability of the polypropylene fibers is showed as an alternative of reinforcement and improvement of the geotechnical behavior of the studied tailings.

\section{Keywords}

Iron mine tailings; gold mine tailings; polypropylene fiber; shear strength; tailing dams. 


\section{Sumário}

1. Introdução 20

1.1. Relevância e Justificativa da Pesquisa 20

1.2. Objetivos 22

1.3. Organização da Tese 22

2. Revisão Bibliográfica $\quad 24$

2.1. Considerações Iniciais 24

2.2. Barragens para rejeito de mineração 24

2.2.1. Métodos de Alteamento de barragens 25

2.2.2. Rupturas e incidentes $\quad 27$

2.3. Solos reforçados com fibras $\quad 30$

2.3.1. Desenvolvimento científico dos solos fibroreforçados 30

2.3.2. Material Compósito Fibroso 31

$\begin{array}{ll}\text { 2.3.3. Fibras de reforço } & 31\end{array}$

2.3.4. Fatores de influência em Solos fibroreforçados 34

2.3.5. Pesquisas anteriores sobre interação solo-fibra 37

2.3.6. Influência da adição de fibras nas propriedades dos solos 45

2.4. Rejeitos de minério de ferro e ouro fibroreforçados 49

3. Programa Experimental 52

3.1. Considerações gerais 52

3.2. Fases do trabalho 52

3.3. Equipamentos utilizados e metodologia empregada 53

3.3.1. Ensaios Triaxiais 54

3.3.1.1. Equipamento, instrumentação, aquisição de dados, acessórios 55

3.3.1.2. Metodologia empregada $\quad 59$

3.3.2. Ensaios de cisalhamento direto com plano cisalhado 65

3.3.2.1. Equipamento, instrumentação, aquisição de dados, acessórios 66

3.3.2.2. Metodologia empregada 66 
$\begin{array}{ll}\text { 3.3.2.3. Fase de adensamento } & 68\end{array}$

3.3.2.4. Fase de cisalhamento convencional 69

3.3.2.5. Fase cisalhamento direto com superfície polida 70

$\begin{array}{ll}3.4 \text { Considerações Finais } & 70\end{array}$

4. Caracterização dos rejeitos de minério e fibra de reforço 72

4.1. Procedência das matrizes e reforço 72

4.2. Caracterização dos Rejeitos de Mineração 73

4.2.1. Análise Granulométrica 74

4.2.2. Limites de Atterberg 78

$\begin{array}{ll}\text { 4.2.3. Massa específica dos rejeitos }(\rho s) & 79\end{array}$

4.2.4. Potencial hidrogeniônico $(\mathrm{pH}) \quad 80$

4.2.5. Análise de Fluorescência 81

4.2.6. Microscopia Eletrônica de Varredura (MEV) 82

4.2.7. Máxima densidade seca aparente $\quad 84$

4.2.8. Densidade Relativa 86

4.2.9. Permeabilidade 86

$\begin{array}{ll}\text { 4.3. Caracterização das Fibras de reforço } & 87\end{array}$

4.4. Discussão dos Resultados 90

4.5. Considerações Finais 93

5. Apresentação e discussão dos Resultados 95

5.1. Ensaios triaxiais 95

5.1.1. Rejeito de Minério de Ferro (RMFe) 96

5.1.1.1. Ensaio triaxial drenado (CD) 96

5.1.1.2. Ensaio triaxial não drenado (CU) 99

5.1.2. Rejeito de Minério de Ouro (RMAu) 104

5.1.2.1. Ensaio triaxial drenado (CD) 104

5.1.2.2. Ensaio triaxial não drenado (CU) 108

5.1.3. Linha de estado Crítico (LEC) 112

5.1.4. Envoltórias e Parâmetros de Resistência 117

5.1.4.1. Rejeito de Minério de Ferro 117

5.1.4.2. Rejeito de Minério de Ouro 120

5.1.5. Módulo de deformabilidade e relação de deformações 123 
5.1.5.1. Rejeito de Minério de Ferro 124

5.1.5.2. Rejeito de Minério de Ouro 127

5.1.6. Comportamento Normalizado q/p' x taxa de dilatância 130

5.1.7. Análise da Rigidez 132

5.1.8. Energia de Deformação Absorvida 135

5.1.9. Variação do excesso de poropressão 137

5.1.9.1. Linha de Transformação de fase 140

5.1.9.2. Ângulo de atrito Mobilizado 143

5.2. Ensaios de cisalhamento direto 145

5.2.1. Rejeito de Minério de Ferro 145

5.2.2. Rejeito de Minério de Ouro 150

5.3. Discussão dos Resultados 156

5.3.1. Variação dos Parâmetros de Resistência 156

5.3.2. Variação do Comportamento Volumétrico 157

5.3.3. Variação da Energia de deformação 158

5.3.4. Variação nos Parâmetros de deformabilidade 158

5.3.5. Variação da rigidez 160

5.3.6. Variação da taxa de dilatância 160

5.3.7. Variação do excesso de poropressão 161

5.4. Exemplo de aplicação 163

6. Conclusões e sugestões para trabalhos futuros 165

6.1. Conclusões 165

6.1.1. Caracterização dos rejeitos de mineração 165

6.1.2. Influência na resistência mecânica 166

6.1.2. Influência no comportamento volumétrico 168

6.2. Sugestões para trabalhos futuros 170

7. Referências bibliográficas 171 


\section{Lista de Figuras}

Figura 2.1. Métodos de Alteamento de barragens ..............................................25

Figura 2.2. Ocorrência de incidentes em barragens de mineração por países ....... 27

Figura 2.3. Incidentes em barragens de mineração por método de alteamento.....28

Figura 2.4. Ruptura da barragem Fundão ………..............................................2 29

Figura 2.5. Ruptura da barragem Huancapeti.......................................................2 29

Figura 3.1. Distribuição de válvulas no equipamento triaxial ...............................54

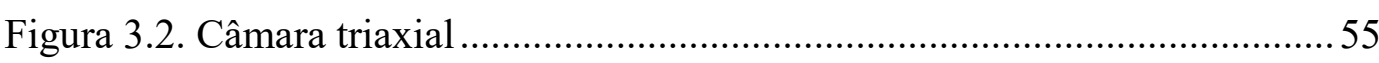

Figura 3.3. Distribuição de válvulas no equipamento triaxial..............................56

Figura 3.4. Medidor de variação de volume tipo Imperial College........................55

Figura 3.5. Sistema de Aquisição de dados .......................................................... 58

Figura 3.6. Verificação da continuidade da membrana de látex ............................60

Figura 3.7. Sequência da montagem do corpo de prova....................................... 61

Figura 3.8. Processo de mistura rejeito de minério - fibra ...................................62 62

Figura 3.9. Sequência da montagem do corpo de prova....................................... 63

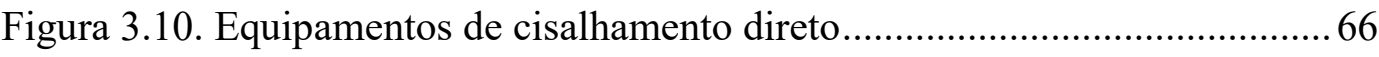

Figura 3.11. Ferramentas e moldagem do rejeito de minério de ferro ...................67 67

Figura 3.12. Ferramentas e moldagem do rejeito de minério de ouro...................6 67

Figura 3.13. Sequência da montagem do corpo de prova..................................... 69

Figura 3.14. Esquema de corte e polimento da superfície cisalhada .................... 70

Figura 4.1. Curvas granulométricas no Rejeito de minério de ferro ..................... 75

Figura 4.2. Ensaios de sedimentação no Rejeito de minério de ferro .................... 75

Figura 4.3. Curvas granulométricas no Rejeito de minério de ouro ....................... 76

Figura 4.4. Ensaios de sedimentação no Rejeito de minério de ouro..................... 77

Figura 4.5. Densidade relativa dos grãos de rejeito (Gs) ..................................... 79

Figura 4.6. Microscopia eletrônica de varredura ................................................ 82

Figura 4.7. Imagem MEV e pontos EDS no rejeito de minério de Ferro ............... 83

Figura 4.8. Imagem MEV e pontos EDS no rejeito de minério de Ouro .............. 84

Figura 4.9. Ensaio de Proctor Normal - Rejeito de Minério de Ferro .................. 85

Figura 4.10. Ensaio de Proctor Normal - Rejeito de Minério de Ouro .................. 85

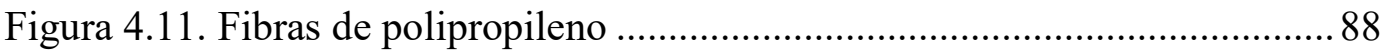

Figura 4.12. Ensaio de tração em fibras de polipropileno ..................................... 89

Figura 4.13. Rejeito de Minério de Ferro e de Ouro ............................................ 91 
Figura 4.14. Coeficiente de uniformidade .......................................................... 91

Figura 4.15. Interação Fibra-Rejeito de Minério de Ferro .................................... 92

Figura 4.16. Interação Fibra-Rejeito de Minério de Ouro ...................................... 93

Figura 5.1. Resultados dos ensaios triaxiais não reforçado CD (RMFe) .............. 97

Figura 5.2. Resultados dos ensaios triaxiais reforçado CD (RMFe) .................... 98

Figura 5.3. Resultados dos ensaios triaxiais não reforçado CU (RMFe) ............ 101

Figura 5.4. Resultados dos ensaios triaxiais reforçado CU (RMFe) ................... 102

Figura 5.5. Razão de tensões principais efetivas vs. deformação axial (RMFe). 103

Figura 5.6. Resultados dos ensaios triaxiais não reforçado CD (RMAu)............ 106

Figura 5.7. Resultados dos ensaios triaxiais reforçado CD (RMAu) .................. 107

Figura 5.8. Resultados dos ensaios triaxiais não reforçado CU (RMAu)............ 109

Figura 5.9. Resultados dos ensaios triaxiais reforçado CU (RMAu) .................. 110

Figura 5.10. Razão de tensões principais efetivas (RMAu) ……........................ 112

Figura 5.11. Linha do estado crítico (RMFe) .................................................... 114

Figura 5.12. Trajetórias não drenadas e linha de estado crítico (RMFe)............. 115

Figura 5.13. Linha do estado crítico (RMAu) ................................................... 116

Figura 5.14. Trajetórias não drenadas e linha de estado crítico (RMAu)............ 117

Figura 5.15. Envoltória de resistência (a) drenada e (b) não drenada (RMFe) ... 119

Figura 5.16. Envoltória de resistência não reforçada e reforçada final (RMFe) . 119

Figura 5.17. Trajetórias de tensão (RMFe) ....................................................... 120

Figura 5.18. Envoltória de resistência (a) drenada e (b) não drenada (RMAu) .. 122

Figura 5.19. Envoltória de resistência não reforçada e reforçada final (RMAu) 122

Figura 5.20. Trajetórias de tensão (RMAu) ...................................................... 123

Figura 5.21. Esquema do módulo de deformabilidade em rejeito de minério .... 124

Figura 5.22. Módulo de deformabilidade (RMFe) ........................................... 126

Figura 5.23. Relação de deformações (RMFe)................................................. 126

Figura 5.24. Interação fibra-grão durante a deformação axial (RMFe)............... 127

Figura 5.25. Módulo de deformabilidade (RMAu) .......................................... 128

Figura 5.26. Relação de deformações (RMAu) ................................................. 129

Figura 5.27. Relação entre q/p' e a taxa de dilatação.......................................... 130

Figura 5.28. Comportamento normalizado q/p' vs. taxa de dilatação (RMFe)... 131

Figura 5.29. Comportamento normalizado q/p' vs. taxa de dilatação (RMAu) .. 131

Figura 5.30. Rigidez dos solos comparados com testes de laboratório ................ 133

Figura 5.31. Módulo cisalhante drenado (RMFe) ............................................. 134 
Figura 5.32. Módulo cisalhante não drenado (RMFe)....................................... 134

Figura 5.33. Módulo cisalhante drenado (RMAu) ............................................. 134

Figura 5.34. Módulo cisalhante não drenado (RMAu)........................................ 135

Figura 5.35. Energia de deformação absorvida CD ao 20\% de $\varepsilon_{\mathrm{a}}(\mathrm{RMFe})$......... 135

Figura 5.36. Energia de deformação absorvida CU ao 20\% de $\varepsilon_{\mathrm{a}}(\mathrm{RMFe})$......... 136

Figura 5.37. Energia de deformação absorvida CD ao 20\% de $\varepsilon_{\mathrm{a}}$ (RMAu) ........ 136

Figura 5.38. Energia de deformação absorvida CU ao 20\% de $\varepsilon_{\mathrm{a}}$ (RMAu) ........ 136

Figura 5.39. Taxa de variação do excesso de poropressão vs. $\varepsilon_{\mathrm{s}}(\mathrm{RMFe})$............ 139

Figura 5.40. Taxa de variação do excesso de poropressão vs. $\varepsilon_{\mathrm{s}}(\mathrm{RMAu})$.......... 139

Figura 5.41. Esquema da posição da Linha de transformação de fase ................ 140

Figura 5.42. Linha de transformação de fase (RMFe)........................................ 141

Figura 5.43. Linha de transformação de fase (RMAu) ....................................... 142

Figura 5.44. Ângulo de atrito mobilizado (RMFe)........................................... 143

Figura 5.45. Ângulo de atrito mobilizado (RMAu) ........................................... 144

Figura 5.46. Cisalhamento direto não reforçado (RMFe) ................................. 147

Figura 5.47. Cisalhamento direto reforçado (RMFe) ....................................... 148

Figura 5.48. Resultados do cisalhamento direto (RMFe).................................. 149

Figura 5.49. Cisalhamento direto não reforçado (RMAu)................................. 152

Figura 5.50. Cisalhamento direto reforçado (RMAu) ........................................ 153

Figura 5.51. Resultados do cisalhamento direto (RMAu) ................................ 154

Figura 5.52. Envoltória polinomial não reforçada (RMAu) ............................... 155

Figura 5.53. Variação do excesso de poropressão normalizada (RMFe) ............ 161

Figura 5.54. Variação do excesso de poropressão normalizada (RMAu) ........... 161

Figura 5.55. Análise de Estabilidade 1,5H:1V - não reforçado .......................... 163

Figura 5.56. Análise de Estabilidade 1,5H:1V - reforçado ................................. 163

Figura 5.57. Análise de Estabilidade 1H:1V - reforçado .................................... 164 


\section{Lista de Tabelas}

Tabela 2.1. Comparação entre as Técnicas de Alteamento ..................................26

Tabela 2.2. Propriedades físicas e mecânicas das fibras vegetais ........................ 32

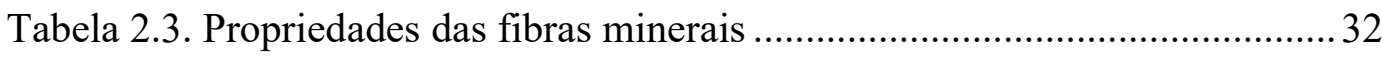

Tabela 2.4. Propriedades das fibras de aço........................................................... 33

Tabela 2.5. Características das fibras poliméricas................................................ 33

Tabela 2.6. Propriedades das fibras poliméricas .................................................. 33

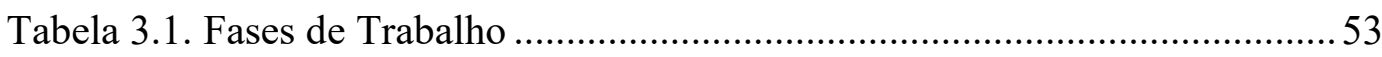

Tabela 4.1. Análises Granulométrica do Rejeito de Minério de Ferro.................. 74

Tabela 4.2. Índices físicos do Rejeito de minério de ferro .................................. 75

Tabela 4.3. Análises Granulométrico do Rejeito de Minério de Ouro ...................76

Tabela 4.4. Índices físicos do rejeito de minério de ouro..................................... 77

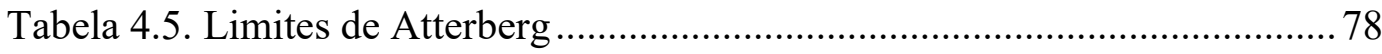

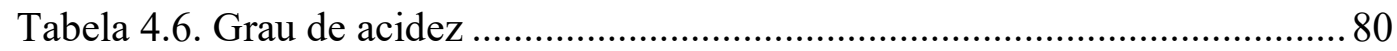

Tabela 4.7. Análise de fluorescência de raios X.................................................. 81

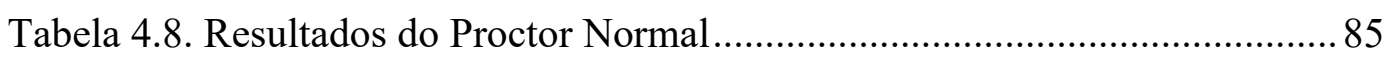

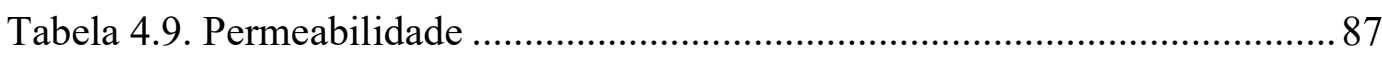

Tabela 4.10. Características técnicas das fibras de polipropileno ......................... 88

Tabela 4.11. Valores resistência à tração em fibras de polipropileno .................... 89

Tabela 4.12. Resumo dos resultados de caracterização.......................................... 90

Tabela 5.1. Variação dos índices físicos CD (RMFe) ........................................... 96

Tabela 5.2. Variação dos índices físicos CU (RMFe) ........................................ 100

Tabela 5.3. Variação dos índices físicos CD (RMAu) ....................................... 104

Tabela 5.4. Variação dos índices físicos CU (RMAu) ........................................ 108

Tabela 5.5. Linha de Estado Crítico não reforçado (RMFe) ............................... 113

Tabela 5.6. Suposta Linha de Estado Crítico reforçado (RMFe) ........................ 113

Tabela 5.7. Linha de Estado Crítico não reforçado (RMAu) ............................... 115

Tabela 5.8. Suposta Linha de Estado Crítico reforçado (RMAu) ....................... 116

Tabela 5.9. Envoltória de Resistência não reforçado (RMFe) ............................ 118

Tabela 5.10. Envoltória de Resistência reforçado (RMFe) ................................ 118

Tabela 5.11. Envoltória de Resistência não reforçada (RMAu) ......................... 121

Tabela 5.12. Envoltória de Resistência reforçada (RMAu)................................ 121

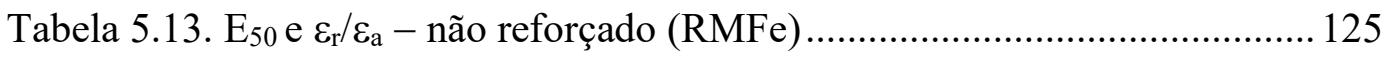




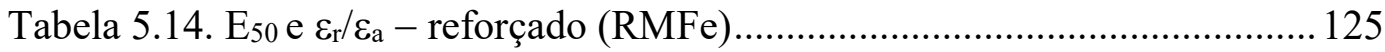

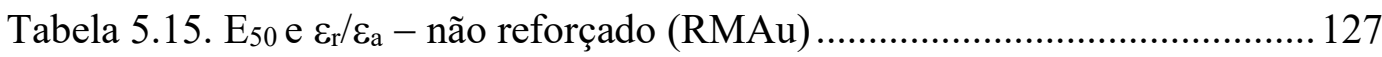

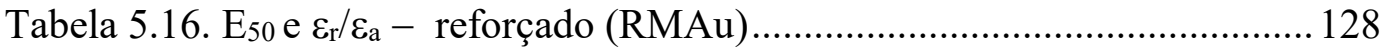

Tabela 5.17. Linha de transformação de fase (RMFe) ........................................ 141

Tabela 5.18. Linha de transformação de fase (RMAu) ...................................... 142

Tabela 5.19. Variação dos índices físicos - cisalhamento direto (RMFe) .......... 145

Tabela 5.20. Resultados Rejeito de Minério de Ferro não reforçado ................... 146

Tabela 5.21. Resultados Rejeito de Minério de Ferro reforçado.......................... 146

Tabela 5.22. Variação dos índices físicos - cisalhamento direto (RMAu) ......... 150

Tabela 5.23. Resultados Rejeito de Minério de Ouro não reforçado ................... 151

Tabela 5.24. Resultados Rejeito de Minério de Ouro reforçado .......................... 151

Tabela 5.25. Variação no Ângulo de atrito......................................................... 156

Tabela 5.26. Variação no Intercepto coesivo .................................................... 156 


\section{Lista de Símbolos e abreviações}

$\begin{array}{ll}\# & \text { número } \\ \% & \text { porcentagem } \\ \text { o } & \text { grau } \\ \% & \text { polegada }\end{array}$

ABNT Associação Brasileira de Normas Técnicas

ANA Autoridad Nacional del Agua

B parâmetro de Skempton

c' intercepto coesivo

$\mathrm{cm} \quad$ centímetro

CBR California Bearing Ratio

C celsius

$\mathrm{Cc} \quad$ coeficiente de curvatura

CD ensaio triaxial drenado

CID adensado isotropicamente drenado

CIU adensado isotropicamente não drenado

CL-ML argila siltosa de baixa plasticidade

$\mathrm{CU}$

ensaio triaxial não drenado

$\mathrm{Cu}$

coeficiente de uniformidade

$\mathrm{Cv}$

coeficiente de adensamento

dh

deslocamento horizontal

$\mathrm{dv}$

deslocamento vertical

DEQM Departamento de Química e Materiais

DGAAM Dirección General de Asuntos Ambientales Mineros

DNER Departamento Nacional de Estradas de Rodagem

Dr

$\mathrm{D}_{10}$

$\mathrm{D}_{50}$

densidade relativa

diâmetro efetivo

diâmetro médio

$\mathrm{e}$

índice de vazios

$\mathrm{e}_{0} \quad$ índice de vazios inicial

e adens índice de vazios após o adensamento

$\mathrm{e}_{\mathrm{f}} \quad$ índice de vazios final

$\mathrm{E}_{\mathrm{i}} \quad$ Módulo tangente inicial

E $50 \quad$ Módulo de deformabilidade ao $50 \%$ da tensão de ruptura

EDS Energy Dispersive Spectrometry

E Energia de deformação

EMBRAPA Empresa Brasileira de Pesquisas Agrárias

FEAM Fundação Estadual do Meio Ambiente

g grama

gf grama-força

G módulo cisalhante 


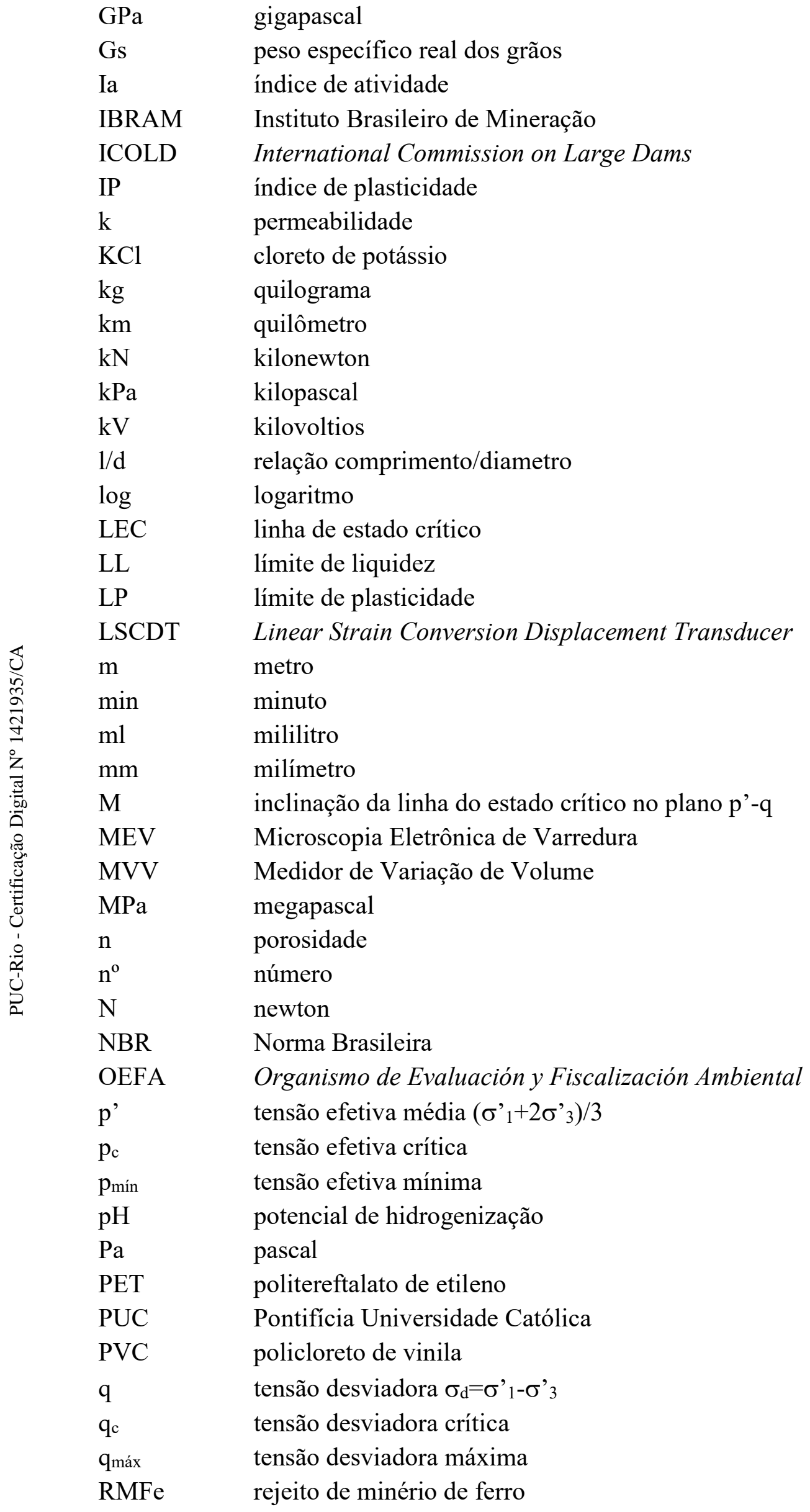




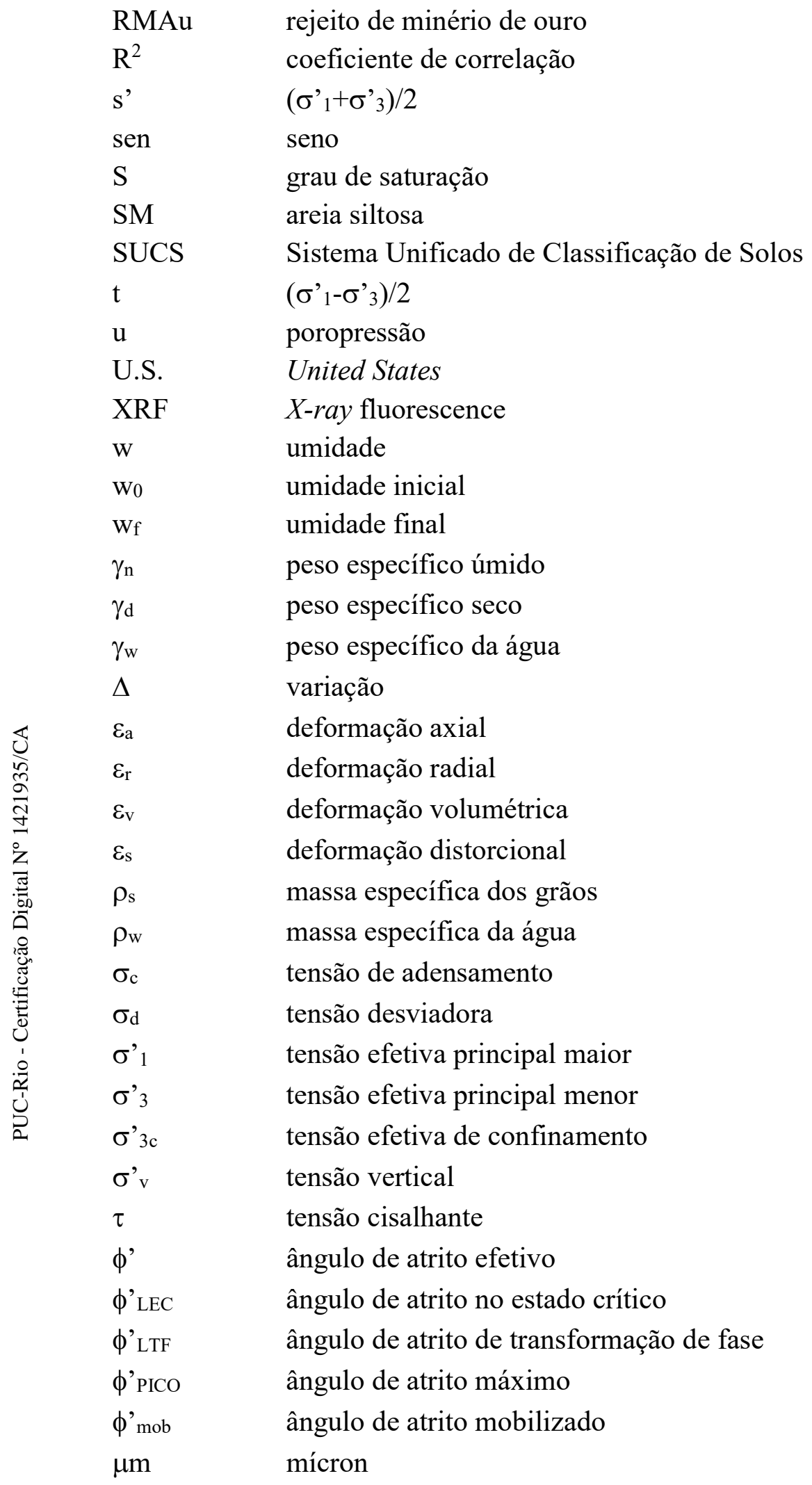


Si puedes soñar y no dejar que los sueños te dominen; Si puedes pensar y no hacer de los pensamientos tu objetivo;

Si puedes encontrarte con el Triunfo y la Derrota $Y$ tratar a estos dos impostores de la misma manera;

Si puedes llenar el preciso minuto Con sesenta segundos de un esfuerzo supremo,

Tuya es la Tierra y todo lo que hay en ella, $Y$, lo que es más, serás un Hombre, ¡hijo mío!

Rudyard Kipling, Carta de un Padre a su Hijo. 


\section{1. Introdução}

\section{1.}

\section{Relevância e Justificativa da Pesquisa}

Os minerais metálicos se encontram misturados com diferentes elementos dentro das rochas, e podem ser retirados por processos mecânicos e químicos realizados em plantas concentradoras para posterior venda às empresas siderúrgicas. Os elementos sem valor comercial normalmente constituem a maior porcentagem constituinte das rochas, portanto ao retirar os minerais de interesse são geradas grandes quantidades de material residual, considerado como rejeito de mineração (tailings).

Os rejeitos de mineração devem ser colocados em locais que garantam condições de segurança e prevenção de danos ao meio ambiente. A forma de armazenamento desses rejeitos é determinada pelo tipo de material, a topografia do local e as condições ambientais existentes. As metodologias empregadas para o armazenamento são diversas, mas critérios tecnológicos e econômicos reduzem as escolhas para conseguir eficiência e eficácia para colocar os rejeitos num local que possa contê-los sem comprometer o meio ambiente nem afetar a velocidade de produção da mina. A construção de barragens é a metodologia mais utilizada pelas empresas de beneficiamento para conter o material lançado na forma de lama, realizando sucessivos alteamentos no corpo da barragem.

O método economicamente mais atrativo para o construtor é o alteamento feito pelo método de montante. Uma prática comum para incrementar o nível máximo de armazenamento em países que não apresentam sismos é utilizar o próprio rejeito de minério como material de conformação dos diques de alteamento, com o uso do rejeito se suprimem os custos derivados de utilizar materiais de empréstimo, em contrapartida, é o método que estatisticamente ocasiona maiores instabilidades em barragem de rejeitos.

U.S.Geological Survey (2018) reportou que o Brasil e o Peru ocupam a sexta posição a nível mundial na produção de ferro e ouro respectivamente, sendo os 
maiores produtores na América Latina, portanto, é relevante melhorar os processos construtivos para estruturas de contenção de rejeitos de mineração.

Outo fato relevante é que as falhas ou acidentes não são alheias nas barragens de mineração nem são um problema do passado podendo mencionar, sem ir muito longe, a ruptura das barragens do Fundão da Mineradora Samarco (Samarco, 2015) e a barragem de Huacapetí da Mineradora Licuna (OEFA, 2018), localizadas no Brasil e no Peru, respectivamente.

Com a finalidade de melhorar as características geotécnicas dos rejeitos utilizados na conformação de diques de mineração, o presente trabalho visa colocar um reforço discreto baseado na inserção de fibras de polipropileno aleatoriamente distribuídas, procurando a homogeneidade na matriz, para comparar o comportamento do rejeito não reforçado e reforçado e determinar as vantagens ou desvantagens de colocar esse tipo de reforço.

A literatura mostra que este tipo de reforço em solos é aplicável, rentável e não prejudica ao meio ambiente, além disso, pesquisas mostram que fibras podem ser utilizadas em diversos trabalhos de engenharia geotécnica como aterros e estradas (Santoni et al., 2001; Tingle et al., 2002; Mahipal, 2008), muros de contenção (Arenicz \& Chowdhury, 1988; Park \& Tan, 2005), engenharia sísmica (Leflaive, 2001; Behzad \& Sherif, 2015) e proteção de encostas (Zornberg, 2002; Bhardwaj \& Mandal, 2008) e fundações (Sharma \& Kumar, 2017; Wasti \& Butun, 1996). A maioria das pesquisas mostram que o reforço de fibras melhora os parâmetros de resistência para solos e que uma porcentagem de $0,5 \%$ do peso seco da matriz é adequada para realizar a mistura (Consoli et al., 2003; Consoli et al., 2007; Consoli et al., 2009; Anagnostopoulos et al., 2013).

$\mathrm{Na}$ última década, o interesse em pesquisar a interação fibra-rejeito de mineração vem aumentando, tomando em consideração os estudos anteriores para reforço de solos, mas a maioria das pesquisas avaliam a resposta drenada (Consoli et al, 2003; Diambra et al., 2010; Costas et al 2013; Anagnostopoulos et al., 2013; etc.), enquanto os depósitos de rejeitos muitas vezes rompem pelo excesso da poropressão. Este trabalho pretende entender o comportamento volumétrico do rejeito reforçado e como a fibra influi na variação da poropressão na condição não drenada.

A hipótese para esta pesquisa consiste em que o reforço de fibras de polipropileno melhora os parâmetros de resistência da matriz porque a interação 
fibra-grão de rejeito tem influência na tendência à mudança volumétrica tanto na condição drenada como não drenada influindo também na variação da poropressão na condição não drenada.

\section{2.}

\section{Objetivos}

O objetivo principal desta pesquisa consiste em estudar o comportamento mecânico e volumétrico do rejeito de minério de ferro e ouro reforçados com fibras de polipropileno aleatoriamente distribuídas sob a condição drenada e não drenada.

Para cumprir com esse objetivo principal é preciso cumprir com os seguintes objetivos específicos:

$>$ Visualizar a interação fibra - rejeito de minério para verificar a influência do reforço no comportamento de rejeitos distintos;

Avaliar o comportamento mecânico e volumétrico dos rejeitos de minério de ferro e ouro, não reforçados e reforçados, utilizando tensões efetivas de 50, 100, 200 e $400 \mathrm{kPa}$ em ensaios triaxiais consolidados isotropicamente drenado (CD) e não drenado $(\mathrm{CU})$ com análises das trajetórias das tensões e da evolução da poropressão gerada nas amostras durante o cisalhamento;

Estudar o comportamento mecânico e volumétrico dos rejeitos de minério de ferro e ouro, não reforçados e reforçados na condição residual mediante ensaios de cisalhamento direto com plano cisalhado e superfície polida, utilizando tensões efetivas de 25, 50, 100, 200 e $400 \mathrm{kPa}$.

\section{3 .}

\section{Organização da Tese}

Para o melhor entendimento deste trabalho, o mesmo é apresentado em seis capítulos, incluindo esta introdução, sendo descritos a seguir, resumidamente, o conteúdo de cada um deles.

O Capítulo 2 abrange uma revisão bibliográfica sobre os temas relacionados ao objetivo da pesquisa, dando uma noção básica sobre disposição de rejeitos de mineração, solos e rejeitos de minério reforçados com fibras, bem como o comportamento mecânico e volumétrico dos compósitos fibroreforçados.

No Capítulo 3 é apresentado o programa experimental junto com os equipamentos utilizados dos ensaios de laboratório, usados para identificar as 
características de resistência dos rejeitos de minério estudados. Além disso, descrevem-se as metodologias dos ensaios triaxiais e de cisalhamento direto com plano cisalhado e superfície polida.

No Capítulo 4 apresenta-se a procedência, caracterização física e química dos rejeitos de minério de ferro e de ouro, e as características física e mecânica da fibra de reforço.

No Capítulo 5 são apresentados os resultados da caracterização mecânica dos rejeitos não reforçados e reforçados de ferro e de ouro, finalizando com a discussão da influência do reforço nas matrizes de rejeito.

No Capítulo 6 são apresentadas as principais conclusões e sugestões para futuros trabalhos.

No final da tese encontram-se as Referências Bibliográficas e um Apêndice onde são apresentadas imagens dos corpos de prova não reforçado e reforçado após os ensaios triaxiais drenados e não drenados. 


\section{2. \\ Revisão Bibliográfica}

\section{1.}

\section{Considerações Iniciais}

Neste capítulo, apresenta-se uma revisão da literatura sobre barragens de mineração, os principais métodos de alteamento e os incidentes e acidentes reportados para entender a importância de procurar técnicas de reforço para estes materiais, posteriormente se realiza uma revisão sobre estudos referentes ao emprego de fibras como reforço de solo, com especial ênfase nas mudanças das propriedades mecânicas, a interação fibra-solo e os principais fatores de influência na resistência dos materiais reforçados com fibras.

\section{2. \\ Barragens para rejeito de mineração}

No Brasil e no Peru, a produção mineral se destaca particularmente na região do Quadrilátero Ferrífero e na cordilheira central dos Andes, respectivamente. No Brasil, somente no quadrilátero ferrífero até o ano 2018 foram registradas 435 barragens de rejeitos de minério de ferro (FEAM, 2018), enquanto no Peru, a totalidade das barragens de rejeito registradas para todos os minerais explorados alcançam o número de 113 (ANA, 2016).

O número das barragens no Peru deve-se principalmente a fatores geográficos, sociais e políticos, o Peru possui uma geografia muito acidentada e encontrar locais de disposição de rejeitos é difícil, as disputas entre as empresas mineradoras e as comunidades também evitam a factibilidade de muitos projetos porque as voçorocas, vales e lagoas são comumente afetadas pela atividade de mineração. Finalmente a informalidade na exploração, que não é regularizada por questões políticas, gera a rejeição a qualquer atividade mineradora formal nas zonas acostumadas à degradação do meio ambiente. No Brasil existe uma ampla tradição na construção de barragens. 
Uma barragem de rejeito é normalmente planejada para ser construída em etapas condicionadas ao espaço geográfico para disposição. A primeira etapa é um aterro inicial, ou um dique de partida, construído com solo compactado. A construção dessa barragem é complementada por alteamentos sucessivos, que podem ser implantados utilizando o próprio rejeito ou os materiais externos procedentes da área de empréstimo ou do estéril de mina.

Durante o alteamento das barragens de rejeito, o método mais utilizado no Brasil, assim como no mundo, é o alteamento para montante (IBRAM, 2016), porque é o método mais económico (Soares et al. 2000), enquanto esse método é evitado no Peru uma vez que as condições sísmicas do país definitivamente exigem uma maior segurança na construção (DGAAM, 2009). Nesse método, a praia de rejeito constitui fundação para o novo dique de alteamento, o que exige mais atenção em termos de segurança da barragem (Vick, 1983). A seguir se faz uma breve apresentação dos métodos construtivos e os principais incidentes segundo o tipo de alteamento de barragens construído.

\subsection{1.}

\section{Métodos de Alteamento de barragens}

Após o enchimento do depósito inicial, o aproveitamento do espaço gera a necessidade de continuar colocando rejeitos de mineração, se as condições de estabilidade física permitem, portanto o alteamento tem como objetivo aumentar a vida útil do local de disposição. Pequenos diques de partida são construídos e os rejeitos são lançados sobre o rejeito de fundação existente. Os métodos de alteamento são três: montante, jusante e linha central (ver Figura 2.1).

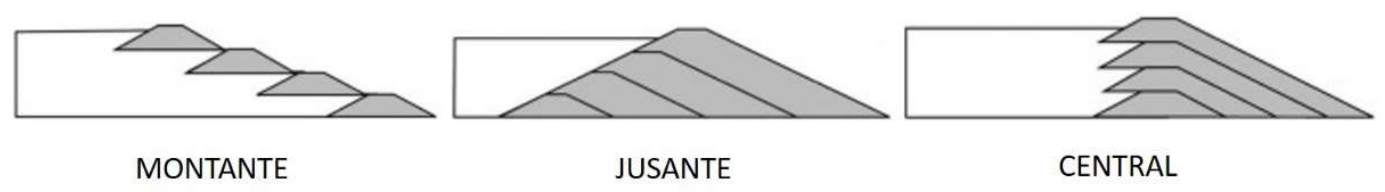

Figura 2.1. Métodos de Alteamento de barragens

No método de montante, o processo desloca o eixo da barragem para o interior da praia de rejeitos. Este método dificulta o controle da infiltração porque a forma de descarga dos rejeitos impede construir um sistema de drenagem continuo na face de montante, além de que, a segurança é crítica porque os alteamentos são depositados sobre o rejeito não consolidado (Araújo, 2006) podendo apresentar 
baixa resistência ao cisalhamento e susceptibilidade à liquefação se o rejeito é arenoso, de outro lado, é atrativo por ser o mais económico (Verdugo, 2009).

$\mathrm{O}$ método de jusante desloca o eixo da barragem para o exterior do dique de partida. A maior vantagem deste método é que o alteamento não é suportado pela praia de rejeitos, portanto, a barragem é mais estável em relação aos outros métodos, além disso, pode ser construida uma estrutura para controle de drenagem interna. A grande desvantagem é que é necessário mais espaço na área da jusante para o corpo da barragem. No método de linha central, o eixo do dique de partida serve como eixo para o alteamento, este método permite também a construção de estruturas para o controle da drenagem interna, e a área adicional ocupada na jusante é menor do que no método de jusante. A desvantagem é que parte do alteamento situa-se sobre a praia de rejeitos podendo apresentar fissuras internas.

A Tabela 2.1. compara os diferentes tipos de alteamento, levando em conta aspectos econômicos, construtivos, e questões relacionadas à estabilidade e porcentagem de incidentes reportados.

Tabela 2.1. Comparação entre as Técnicas de Alteamento

\begin{tabular}{|c|c|c|c|}
\hline Método & Montante & Jusante & Linha Central \\
\hline Custo & Menor custo & Mais elevado & Econômico \\
\hline Material & $\begin{array}{l}\text { fração grossa } \\
\text { do rejeito } \\
\text { (underflow) }\end{array}$ & $\begin{array}{c}\text { fração grossa } \\
\text { do rejeito (underflow) } \\
\text { mistura } \\
\text { underflow /material de } \\
\text { empréstimo } \\
\text { material de empréstimo }\end{array}$ & $\begin{array}{c}\text { fração grossa } \\
\text { do rejeito (underflow) } \\
\text { mistura } \\
\text { underflow /material de } \\
\text { empréstimo } \\
\text { material de empréstimo }\end{array}$ \\
\hline $\begin{array}{c}\text { Volume de } \\
\text { transporte e } \\
\text { compactação }\end{array}$ & Menor & Maior & Eficiente \\
\hline Drenagem & $\begin{array}{l}\text { Dificuldade na } \\
\text { construção }\end{array}$ & Drenagem eficiente & Drenagem eficiente \\
\hline $\begin{array}{c}\text { Uso de área } \\
\text { adicional } \\
\end{array}$ & Não precisa & Precisa espaço maior & Precisa espaço menor \\
\hline Estabilidade & $\begin{array}{l}\text { Possível ruptura } \\
\text { por pipping, } \\
\text { liquefação }\end{array}$ & $\begin{array}{c}\text { Depende da estabilidade física } \\
\text { global }\end{array}$ & $\begin{array}{l}\text { Existe possibilidade de } \\
\text { fissuramento na fase montante } \\
\text { do alteamento }\end{array}$ \\
\hline $\begin{array}{c}\text { Porcentagem de } \\
\text { incidentes no } \\
\text { mundo } \\
\text { (Rico et al., 2008) }\end{array}$ & $76 \%$ & $15 \%$ & $5 \%$ \\
\hline
\end{tabular}

Elaboração própria. 


\subsection{2. \\ Rupturas e incidentes}

Conhecer os acidentes e incidentes proporciona base para melhorar as técnicas construtivas. A palavra acidente se refere a um desastre e a palavra incidente se refere a um desentendimento ou a um acontecimento imprevisto. Uma ruptura de barragem de mineração interrompe a produção, desativa as operações e, no pior dos casos, pode gerar mortes tornando-se um custo extremamente elevado, portanto deve-se garantir a segurança geotécnica com um severo controle e gestão de risco das barragens.

ICOLD (2001) publicou o boletim 121 intitulado: Tailings Dams Risk of Dangerous Occurences, Lessons Learnt From Practical Experiences (Risco de Ocorrências de Perigo em Barragens de rejeito, Lições Aprendidas a Partir de Experiências Práticas), onde é apresentada uma relação com 221 registros dos casos de falhas em barragens de rejeitos espalhados pelo mundo. As principais causas dessas falhas e de incidentes, conforme a perícia, foram a falta de controle da construção, a falta de controle do equilíbrio hídrico e a geral falta de entendimento sobre características que controlam a segurança das operações.

Rico et al. (2008) publicaram um registro dos incidentes em barragens de mineração a nível mundial mostrando que na América Latina Chile, Brasil e Peru possuem uma porcentagem considerável de incidentes reportados como se apresenta na Figura 2.2.

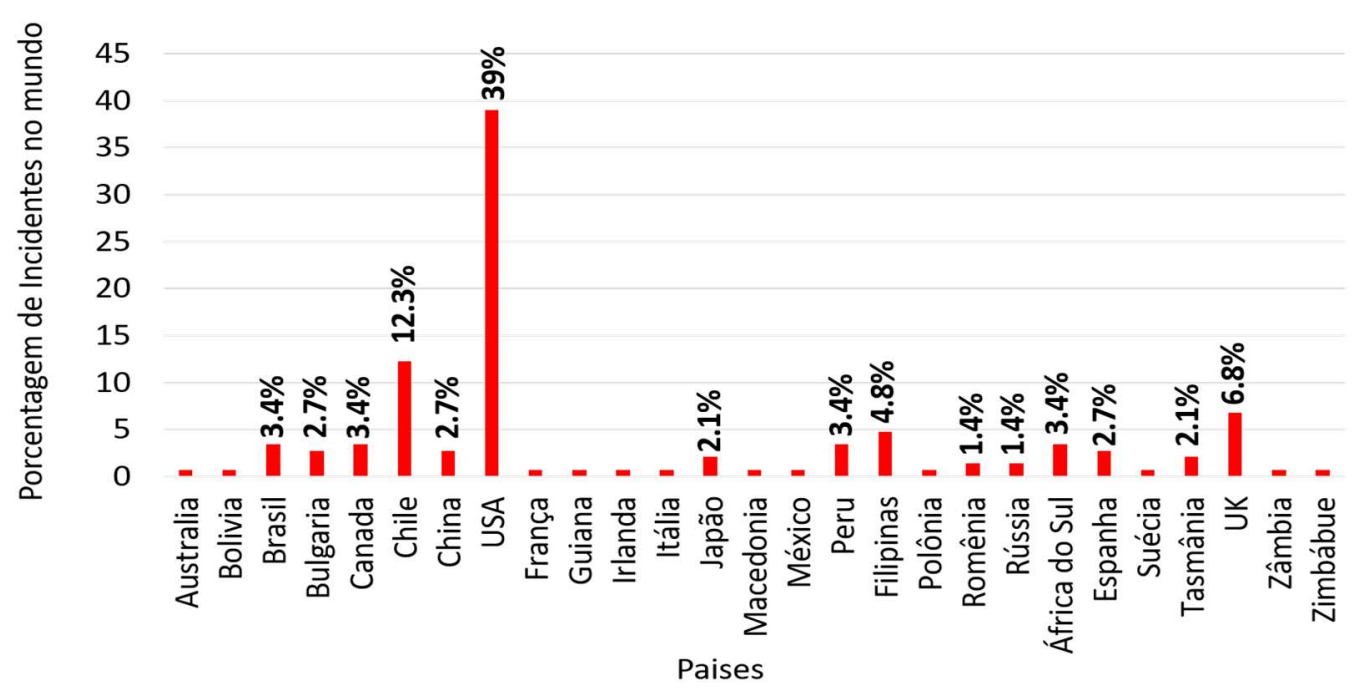

Figura 2.2. Ocorrência de incidentes em barragens de mineração por países (Modificado - Rico et al., 2008) 


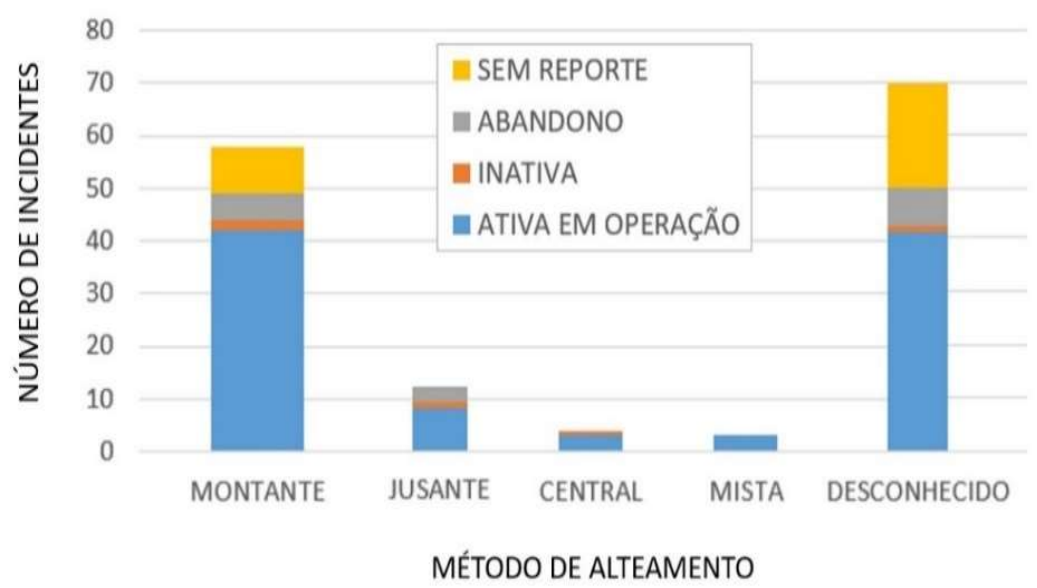

Figura 2.3. Incidentes em barragens de mineração por método de alteamento (Modificado - Rico et al., 2008)

Na Figura 2.3 apresenta-se a distribuição do número de incidentes de acordo com o tipo de construção da barragem (montante, jusante, linha central e construção mista) e o estado de atividade no momento em que a falha ocorreu (barragem ativa em operação, barragem inativa mas mantida, barragem abandonada, falha da barragem não registrada no momento em que aconteceu).

No Brasil, também foram detectados muitos acidentes causados por falhas em barragens de mineração com rupturas desde localizadas até globais como o caso da mineradora Rio Verde, em 2001, que colocava rejeito em Cava usando o método de alteamentos sucessivos para a montante (Gomes et al., 2001).

Cavalcante (2004) relatou a possibilidade de que a sobrecarga pelo alteamento da barragem produziu à ruptura, o aumento da tensão cisalhante sem ganho de resistência ao cisalhamento levou à falha com escoamento da massa de rejeito percorrendo uma distância aproximada de $8 \mathrm{~km}$, com perda de vidas.

O caso mais recente ocorreu na mineradora Samarco o dia 5 de novembro de 2015, em Mariana, na Região Central de Minas Gerais, o rompimento da barragem do Fundão gerou um mar de lama que cobriu o subdistrito de Bento Rodrigues, atingindo municípios vizinhos e poluindo o Rio Doce causando 11 mortes, 12 desaparecimentos e deixando mais de 600 moradores desabrigados. De acordo com a Samarco, 55 bilhões de litros de rejeitos eram armazenados no Fundão. Com o rompimento, uma massa de 40 bilhões se deslocou e levou parte da barragem para água de Santarém. 


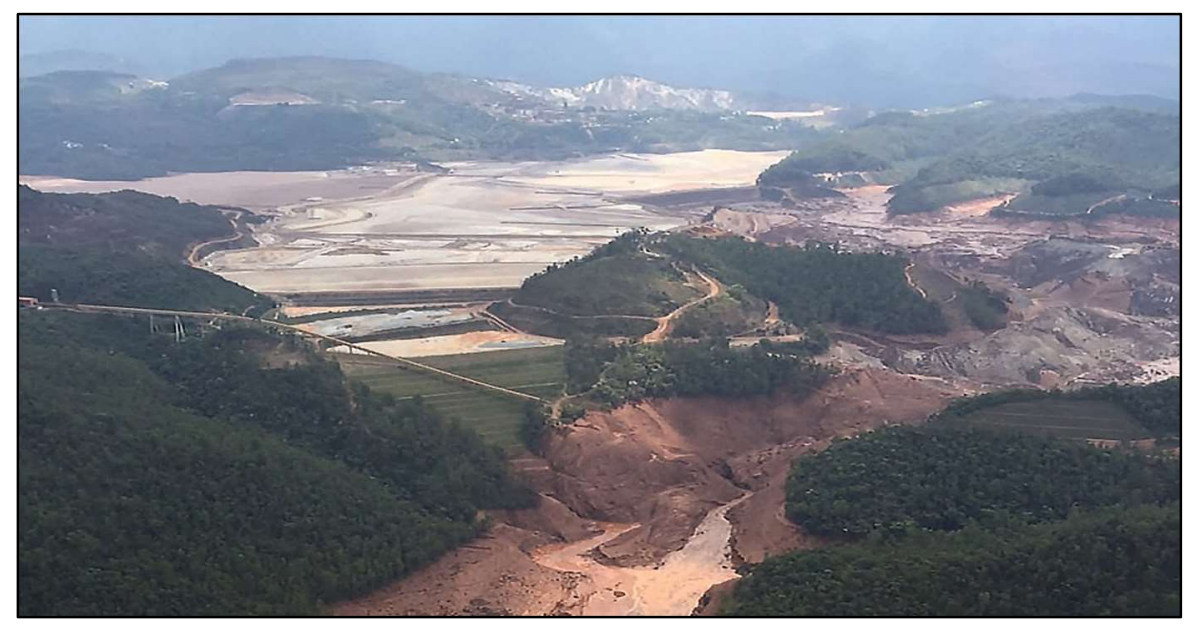

Figura 2.4. Ruptura da barragem Fundão Fonte: Corpo de Bombeiros / Divulgação

No Peru, o último acidente registrado ocorreu no dia 3 de março de 2018, em Recuay, no departamento de Ancash. A ruptura da barragem Huancapetí propriedade da mineradora Licuna produziu um derrame de $50,000 \mathrm{~m}^{3}$ de rejeitos, a falha se localizou na extremidade e na base do dique central na zona de jusante, a lama prejudicou a voçoroca Shipchoc e atualmente se realizam os trabalhos de resgate ambiental.

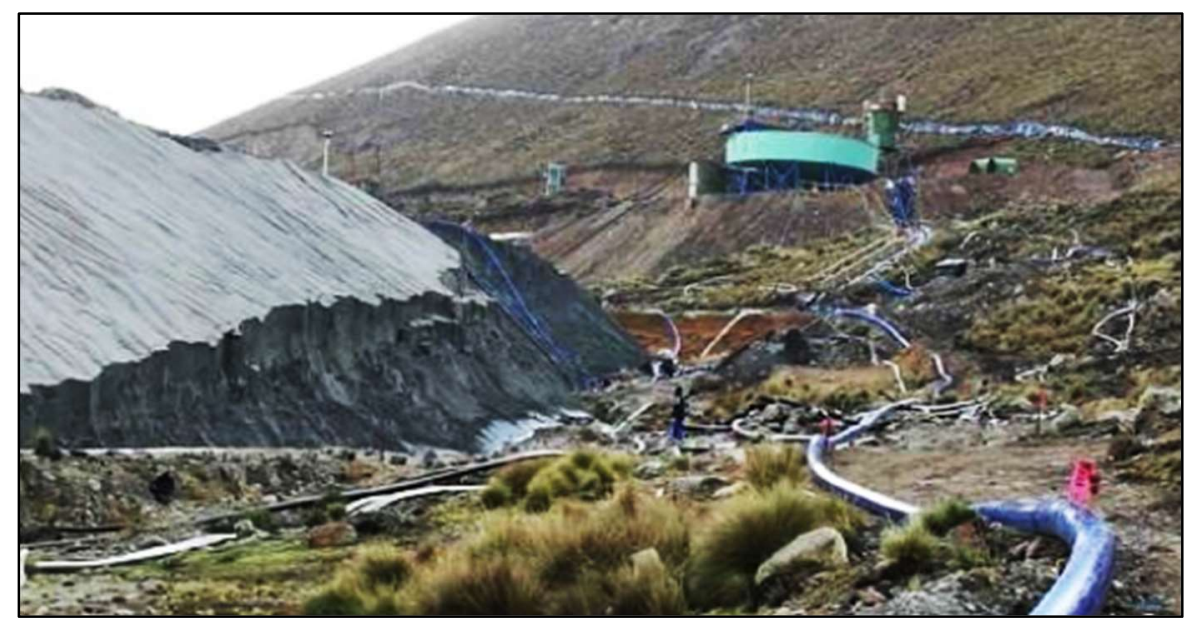

Figura 2.5. Ruptura da barragem Huancapeti Fonte: Agencia Peruana de Noticias / Divulgação

Do exposto observa-se que a estabilidade deste tipo de barragem precisa de maior investigação e controle para melhorar as estruturas, especificamente aquelas construídas com materiais não homogêneos como são os rejeitos de mineração. Antigamente os rejeitos de mineração não recebiam muito interesse por serem materiais descartados, na atualidade, esta postura mudou porque, se o tema não é abordado com a importância do caso, os rejeitos podem causar grandes catástrofes. 


\section{3. \\ Solos reforçados com fibras}

\subsection{1. \\ Desenvolvimento científico dos solos fibroreforçados}

O uso da fibra como reforço de solos é antigo e foi o empirismo que determinou seu uso, enquanto o desenvolvimento científico de pesquisas para entender os mecanismos de interação fibra-solo não é de longa data, porque começou a acontecer há, aproximadamente, três décadas.

Primeiro é importante entender que o termo melhoria de solos é associado a um tratamento através de processos químicos que visam o incremento das propriedades mecânicas, a diminuição da compressibilidade e da permeabilidade do solo tratado, portanto o termo que define a ação das fibras é reforço, que está associado à utilização de inclusões em aterros ou taludes (Casagrande, 2005).

Uma das primeiras pesquisas sobre a influência das raízes sobre a resistência do solo foi feita por Endo \& Tsuruta (1969) que mostraram que a resistência ao cisalhamento do solo com um sistema de raízes podia ser expressada em termos da lei de Coulomb. Nessa década, o interesse levou os pesquisadores a colocar fibras em forma aleatória dentro de uma massa de solo com a finalidade de avaliar as mudanças no comportamento da matriz (Gray \& Ohashi, 1983).

A partir desses trabalhos a comunidade científica realizou um constante desenvolvimento de pesquisas de forma que, na seguinte década, nos livros de Engenharia dos Materiais, os materiais compósitos fibrosos eram abordados em capítulos específicos (Taylor, 1994; Hannant, 1994; Hollaway, 1994; Illston, 1994; Budinski, 1996).

No início do século, a pesquisa de materiais sintéticos para reforço dos solos abriu caminho para dar solução à degradação das fibras orgânicas e conseguir maiores vantagens como uma alta resistência à tração, resistência às altas temperaturas ou resistência ao ataque álcali.

Diversas aplicações começaram a aparecer como, por exemplo, o fibrosolo que consiste na mistura de solo e fibras sintéticas para utilização em pavimentos (Homem, 2002) e aplicações em estradas e aterros sobre solos moles (Santoni et al., 2001; Tingle et al., 2002; Mahipal et al., 2008), muros de contenção (Park \& Tan, 2005), estruturas sísmicas (Leflaive, 2001; Behzad \& Sherif, 2015), estabilidade de 
taludes (Zornberg, 2002, Bhardwaj \& Mandal, 2008) ou em engenharia de fundações (Casagrande et al, 2001, Sharma \& Kumar, 2017).

\subsection{2. \\ Material Compósito Fibroso}

Muitas vezes, quando um projeto torna-se limitado porque um material não possui todas as características desejadas, o trabalho pode ser concretizado usando uma combinação de dois ou mais materiais, gerando o que é chamado de um material compósito. O objetivo destes materiais, segundo Budinski (1996), é conseguir um conjunto de comportamentos ideais produto da união de diferentes materiais que independentemente não conseguiriam esses benefícios.

O compósito é constituído por uma matriz e por um elemento de reforço, sendo ambos desenvolvidos para aperfeiçoar as características inerentes a cada um destes dois componentes. Um material compósito fibroso, segundo Matthews \& Rawlings (1994), é o compósito em que os reforços são as fibras disseminadas na matriz, sendo que a resistência inicial do compósito é fornecida pela matriz.

No caso de solos, a compactação não assegura a completa continuidade da matriz, por isso considera-se que a transferência de tensão matriz-fibra é feita em uma matriz fissurada. Na prática, o efeito principal das fibras produz-se depois do aparecimento da primeira fissura pelo carregamento, onde a ponte de fibras através das trincas propagadas na matriz impede uma ruptura catastrófica (Silva, 2014).

\subsection{3.}

\section{Fibras de reforço}

Fibras de reforço vegetais, minerais, metálicas e poliméricas são descritas a seguir com a finalidade de oferecer uma visão geral das possíveis vantagens de desvantagens do emprego em matrizes de rejeitos de mineração.

\subsubsection{1.}

\section{Fibras vegetais}

As fibras vegetais são classificadas de acordo com sua origem nas plantas e podem ser agrupadas em fibras de caule, fibras de folha, fibras de semente e fibras de fruto. A principal desvantagem das fibras vegetais é sua durabilidade, pois podem ser degradadas por fungos e micro-organismos ou pela exposição em 
ambientes alcalinos que é o caso dos rejeitos de mineração. Além disso, as propriedades de resistência são inferiores comparadas com os outros tipos de fibras. A Tabela 2.2 mostra as propriedades das fibras vegetais mais pesquisadas.

Tabela 2.2. Propriedades físicas e mecânicas das fibras vegetais (Giacomini, 2003; Spinacé et al., 2009; Silveira, 2018)

\begin{tabular}{c|c|c|c|c|c}
\hline Fibra & $\begin{array}{c}\text { Diâmetro } \\
(\boldsymbol{\mu m})\end{array}$ & $\begin{array}{c}\text { Densidade } \\
\text { Específica }\end{array}$ & $\begin{array}{c}\text { Resistência à } \\
\text { tração } \\
(\mathbf{G P a})\end{array}$ & $\begin{array}{c}\text { Módulo de } \\
\text { Young } \\
(\mathbf{G P a})\end{array}$ & $\begin{array}{c}\text { Alongamento } \\
\text { na ruptura } \\
\mathbf{( \% )}\end{array}$ \\
\hline Curauá & 70 & 1.2 & 0.47 & 10.0 & 4.53 \\
\hline Sisal & 228 & 1.1 & 0.27 & 5.51 & 5.21 \\
\hline Rami & - & 1.5 & 0.50 & 27.2 & 1.80 \\
\hline
\end{tabular}

\subsubsection{2.}

\section{Fibras minerais}

Dentre as fibras minerais mais utilizadas na construção civil poderíamos citar as de carbono, vidro e amianto conhecido como asbesto de uso restrito por ser perigosa para a saúde humana. A Tabela 2.3 apresenta as propriedades das fibras minerais mais utilizadas.

Tabela 2.3. Propriedades das fibras minerais

\begin{tabular}{c|c|c|c|c|c}
\hline Fibra & $\begin{array}{c}\text { Diâmetro } \\
(\mu \mathbf{m})\end{array}$ & $\begin{array}{c}\text { Densidade } \\
\text { Específica }\end{array}$ & $\begin{array}{c}\text { Resistência à } \\
\text { tração } \\
(\mathbf{G P a})\end{array}$ & $\begin{array}{c}\text { Módulo de } \\
\text { Young } \\
(\mathbf{G P a})\end{array}$ & $\begin{array}{c}\text { Alongamento } \\
\text { na ruptura } \\
\mathbf{( \% )}\end{array}$ \\
\hline Carbono & 10 & 1.90 & 5.50 & 400 & 1.80 \\
\hline Vidro & 15 & 2.50 & 4.50 & 87 & 5.00 \\
\hline Asbesto & - & 2.50 & 1.00 & 160 & 0.62 \\
\hline
\end{tabular}

\subsubsection{3.}

\section{Fibras metálicas}

As fibras metálicas são utilizadas, geralmente, para incrementar as propriedades mecânicas dos materiais de construção. As mais empregadas são as fibras de aço. A ruptura do compósito é, normalmente, associada ao arrancamento da fibra e não à sua ruptura. Uma desvantagem destas fibras é que podem apresentar problemas de corrosão quando não possuem um recobrimento de níquel. Além disso, sua alta rigidez é uma desvantagem para ser utilizada com os rejeitos de minério que são menos rígidos e muito deformáveis. A Tabela 2.4 apresenta as propriedades das fibras de aço. 
Tabela 2.4. Propriedades das fibras de aço (Bentur \& Mindess, 2007)

\begin{tabular}{c|c|c|c|c|c}
\hline Fibra & $\begin{array}{c}\text { Diâmetro } \\
(\boldsymbol{\mu m})\end{array}$ & $\begin{array}{c}\text { Densidade } \\
\text { Específica }\end{array}$ & $\begin{array}{c}\text { Resistência à } \\
\text { tração } \\
(\mathbf{G P a})\end{array}$ & $\begin{array}{c}\text { Módulo de } \\
\text { elasticidade } \\
(\mathbf{G P a})\end{array}$ & $\begin{array}{c}\text { Alongamento } \\
\text { na ruptura } \\
(\mathbf{\%})\end{array}$ \\
\hline Aço & $100-1000$ & 7,84 & $0,5-2,6$ & 210 & $0,5-3,5$ \\
\hline
\end{tabular}

\subsubsection{4.}

\section{Fibras poliméricas}

A estrutura química das fibras poliméricas é manipulável, portanto se conseguem comportamentos desejáveis em relação à interação matriz-fibra, além disso, as fibras poliméricas são quimicamente neutras, não degradáveis, com ótimas propriedades físicas e mecânicas, e não são prejudiciais à saúde.

Existem diferentes formatos; o reforço do solo pode ser feito com fibras individuais ou tecidos em forma de malha, com aberturas cuja finalidade é de proporcionar o intertravamento das partículas do solo.

Outro tipo de técnica, desenvolvida na França, é a chamada de Texsol, que consiste em filamentos contínuos que são distribuídos aleatoriamente dentro da massa de solo. Nas Tabelas 2.5 e 2.6 apresentam-se as características e propriedades das principais fibras poliméricas.

Tabela 2.5. Características das fibras poliméricas

\begin{tabular}{c|c|c|c}
\hline Polipropileno & Polietileno & Nylon & Acrílicas \\
\hline $\begin{array}{c}\text { Possuem consistência } \\
\text { plástica com aumento } \\
\text { da temperatura }\end{array}$ & $\begin{array}{c}\text { Pouca aderência com } \\
\text { matrizes cimentícias }\end{array}$ & $\begin{array}{c}\text { Pouca aderência com } \\
\text { matrizes cimentícias }\end{array}$ & $\begin{array}{c}\text { Grande aderência com } \\
\text { matrizes cimentícias }\end{array}$ \\
\hline Hidrofóbicas & Hidrofóbicas & $\begin{array}{c}\text { Hidrófilas } \\
\text { Podem absorver até } \\
4,5 \% \text { de água }\end{array}$ & $\begin{array}{c}\text { Hidrófilas } \\
\text { Podem absorver até } \\
2,5 \% \text { de água }\end{array}$ \\
\cline { 1 - 2 } $\begin{array}{c}\text { Estabilidade química } \\
\text { Resistência ao } \\
\text { ataque álcali }\end{array}$ & $\begin{array}{c}\text { Estabilidade química } \\
\text { ataque álcali }\end{array}$ & $\begin{array}{c}\text { Estabilidade química } \\
\text { Resistência ao ataque } \\
\text { álcali }\end{array}$ & $\begin{array}{c}\text { Perdem força em } \\
\text { médios alcalinos }\end{array}$ \\
\hline
\end{tabular}

Elaboração própria.

Tabela 2.6. Propriedades das fibras poliméricas (Bentur \& Mindess, 2007)

\begin{tabular}{c|c|c|c|c|c}
\hline Fibra & $\begin{array}{c}\text { Diâmetro } \\
(\boldsymbol{\mu m})\end{array}$ & $\begin{array}{c}\text { Densidade } \\
\text { Específica }\end{array}$ & $\begin{array}{c}\text { Resistência à } \\
\text { tração } \\
(\mathbf{G P a})\end{array}$ & $\begin{array}{c}\text { Módulo de } \\
\text { elasticidade } \\
(\mathbf{G P a})\end{array}$ & $\begin{array}{c}\text { Alongamento } \\
\text { na ruptura } \\
(\mathbf{\%})\end{array}$ \\
\hline Polipropileno & $20-400$ & $0,90-0,95$ & $0,45-0,76$ & $3,5-10$ & $15-25$ \\
\hline Polietileno & $25-1000$ & $0,92-0,96$ & $0,08-0,60$ & 5,0 & $3-100$ \\
\hline Nylon & $23-400$ & 1,14 & $0,75-1,00$ & $4,1-5,2$ & $16-20$ \\
\hline Acrílica & $20-350$ & $1,16-1,18$ & $0,20-1,00$ & $14-19$ & $10-50$ \\
\hline
\end{tabular}




\subsection{4. \\ Fatores de influência em Solos fibroreforçados}

Nos compósitos fibrosos é importante conhecer certos fatores que ajudam no entendimento do comportamento, esses fatores têm sido amplamente estudados em solos fibroreforçados e se dividem em fatores da influência da fibra, da matriz e da interação fibra-matriz.

\subsubsection{1.}

\section{Fatores de Influência da Fibra}

\section{$\underline{\text { Resistência à tração }}$}

O solo não possui uma significativa resistência à tração, enquanto as fibras trabalham sempre à tração quando são inseridas no solo, portanto, as fibras não impedem a formação de fissuras mas incrementam a resistência a tração do compósito pelo controle da propagação das fissuras (Taylor, 1994).

As fibras que se encontram atravessando a superfície de ruptura durante o cisalhamento, de um lado serão puxadas em sentido do movimento e do outro tentarão se manter no segmento resistente se desenvolvendo a tração nelas. As fibras sintéticas possuem uma alta resistência à tração, portanto, dificilmente serão fragmentadas durante o cisalhamento do solo, antes disso, serão arrancadas de um dos segmentos da matriz. A resistência à tração é importante pois as fibras são esticadas sofrendo deformações plásticas de tração em grandes deformações (Casagrande, 2005) e podem mudar o comportamento volumétrico da matriz. Em modelagens que tentam quantificar a contribuição da fibra no compósito, a tensão distribuída induzida pela fibra é dependente da resistência à tração da fibra quando a falha é governada pela ruptura da fibra (Zornberg, 2002; Li \& Zornberg, 2013).

\section{$\underline{\text { Relação de aspecto }}$}

A relação de aspecto é a razão entre o comprimento e o diâmetro das fibras. Quanto maior for o comprimento, maior é o ganho de resistência mecânica, até um limite (Gray \& Ohashi, 1983; Ulbrich, 1997; Heineck \& Consoli, 2002) e menor será a possibilidade delas serem arrancadas (Casagrande, 2005). Para uma dada tensão de cisalhamento superficial aplicada à fibra, esta será mais bem utilizada se 
seu comprimento for suficientemente capaz de permitir que a tensão cisalhante desenvolva uma tensão de tração igual à sua resistência à tração.

$\mathrm{O}$ aumento do comprimento da fibra provoca aumento da ductilidade e aumento da capacidade de absorção de energia (Ulbrich, 1997). O aumento da relação de aspecto melhora a contribuição da fibra no aumento da resistência ao cisalhamento (Gray \& Maher, 1989).

\section{$\underline{\text { Teor de fibras }}$}

O teor de fibras é um fator importante, um alto teor confere maior resistência pós-fissuração e menor dimensão das fissuras, desde que as fibras possam absorver as cargas adicionais causadas pelas fissuras (Taylor, 1994).

Quanto maior o teor de fibra, maior é o acréscimo de resistência mecânica, até certo limite, a partir do qual este efeito não é mais observado (Gray \& Ohashi, 1983; Gray \& Al-Refeai, 1986; Ulbrich, 1997; Casagrande, 2001; Casagrande, 2005; Consoli et al., 2007b). O aumento do teor de fibra provoca um aumento da capacidade de absorção da energia de deformação (Casagrande, 2005). A inclusão de fibras aumenta a ductilidade (Gray \& Ohashi, 1983; Ulbrich, 1997).

\section{Módulo de elasticidade}

O módulo de elasticidade da fibra é a razão entre a tensão e a deformação na direção da carga aplicada. Um alto valor do módulo de elasticidade resulta na maior probabilidade que as fibras falhem por arrancamento e não por ruptura (Shewbridge \& Sitar, 1990). Fibras relativamente rígidas (fibras de vidro e PET) exercem efeito mais pronunciado na resistência de ruptura, ao passo que fibras relativamente flexíveis (fibras de polipropileno) exercem efeito mais pronunciado no modo de ruptura e no comportamento último (Montardo, 1999; Montardo et al, 2002; Consoli et al., 2002).

\section{Orientação}

A orientação é a posição das fibras no que diz respeito à direção das deformações de tração do solo. A orientação de uma fibra relativa ao plano de ruptura ou fissura influencia fortemente sua capacidade de transmitir cargas. Portanto, uma fibra que se posiciona perpendicular ao plano de ruptura tem efeito 
máximo, enquanto uma paralela, não tem esse efeito (Morel \& Gourc, 1997; Diambra, 2010). Fibras distribuídas aleatoriamente mantém a resistência isotrópica, não sendo observados planos potenciais de ruptura (Gray \& Al-Refeai, 1986; Gray \& Maher, 1989; Zornberg, 2002).

\subsubsection{2.}

Fatores de Influência da Matriz

\section{Densidade}

A densidade do solo tem influência na resistência e até na contribuição da fibra, somente até certo limite de teor de fibra, porque se a matriz for densa e o teor de fibras é alto, a fibra terá uma influência desprezível (Li \& Zornberg, 2013), mas se o teor de fibra é ótimo a contribuição da fibra num solo denso será importante (Casagrande, 2005). Em ensaios de carga em placa se demostrou que o efeito da fibra é maior em solos como densidades relativas mais altas (Consoli \& Casagrande, 2009).

\section{Resistência ao cisalhamento}

A resistência ao cisalhamento da matriz é um fator primordial, pois em um compósito as primeiras tensões são resistidas pela matriz. A maioria dos solos apresentam um comportamento elastoplástico mostrando uma tensão de cisalhamento de pico. No enfoque discreto para o cálculo da resistência ao cisalhamento equivalente do compósito a contribuição da fibra (seja a ruptura governada pelo arrancamento ou pela quebra da fibra) é adicionada à resistência ao cisalhamento da matriz (Zornberg, 2002). Se a matriz apresenta alta coesão, é reduzida a contribuição das fibras para o aumento de resistência de pico do solo (Maher \& Ho, 1993).

\subsubsection{3.}

\section{Fator de Influência da Interface Fibra-Matriz}

\section{Aderência}

A aderência é a resistência ao cisalhamento que acontece na superfície de contato de dois corpos (fibra/matriz) ao tentarem deslizarem-se uns sobre os outros. 
As características de resistência, deformação e padrões de ruptura de uma grande variedade de compósitos reforçados com fibras dependem, fundamentalmente, da aderência fibra/matriz. Uma alta aderência entre a fibra e a matriz reduz o tamanho das fissuras e amplia sua distribuição pelo compósito (Casagrande, 2005). As fibras devem estar bem aderidas à matriz do compósito para que sua resistência à tração seja mobilizada (Taylor, 1994). A aderência depende da granulometria da matriz (tamanho, forma, distribuição dos grãos) e do tipo de superfície da fibra (lisa, fibrilada, etc).

\subsection{5.}

\section{Pesquisas anteriores sobre interação solo-fibra}

Além de conseguir atender as condições dos projetos é imprescindível identificar as causas da melhora de propriedades de uma matriz, dadas pelos mecanismos que regem o comportamento do compósito. A seguir se faz uma revisão dos principais avanços no entendimento do reforço de solos com fibras através do tempo.

Gray \& Ohashi (1983) mostraram que no compósito solo/fibra existe uma tensão de confinamento crítica na qual as tensões abaixo dela geram o arrancamento das fibras enquanto acima as fibras sofrem alongamento. Mediante ensaios de cisalhamento direto mostraram que a fibra aumentou a resistência ao cisalhamento de pico e reduz a queda pós-pico.

Freitag (1986) utilizou um solo residual de calcário misturado com fibras de nylon (descartada no início dos trabalhos pela dificuldade de uma mistura homogênea), de polipropileno (com 0,20 mm de diâmetro) e Fibermesh (polipropileno de 0,10 $\mathrm{mm}$ de diâmetro). O comprimento das fibras foi de $20 \mathrm{~mm}$ e um teor de $1 \%$ em volume. Os resultados indicaram um aumento da resistência à compressão não confinada, para teores de umidade próximos à ótima e no ramo úmido da curva de compactação. As curvas tensão-deformação mostraram que o solo reforçado rompe em uma deformação bem superior à do solo não reforçado, sendo capaz de absorver maior energia de deformação.

Gray \& Maher (1989) encontraram que com a inclusão de fibras é mantida uma resistência isotrópica derivando em ausência de planos de fraqueza que podem ser desenvolvidos em sistemas de reforço orientado. Os autores verificaram que o 
aumento da relação cumprimento/diâmetro (1/d) reduz o valor da tensão crítica e aumenta a resistência ao cisalhamento.

Shewbridge \& Sitar (1989) estudaram a evolução da zona de cisalhamento de um solo granular com reforço de diferentes tipos de fibras. Foram realizados ensaios em equipamento de cisalhamento direto cujas dimensões eram maiores que as convencionais. Para o solo reforçado, a zona de cisalhamento era mais extensa e aumentava com a concentração, rigidez e aderência entre o solo e o reforço. Os autores concluíram que o aumento da resistência é função das propriedades da areia (graduação, tamanho e forma das partículas) e da fibra (teor, relação 1/d e módulo de elasticidade).

O modelo proposto pelos autores para prever o comportamento do solo reforçado com fibras é baseado num modelo aplicado a concreto reforçado com fibras, sendo que, o principal problema é a dificuldade em relação à estimativa da espessura da zona de cisalhamento.

Maher \& Ho (1993) estudaram o comportamento de uma argila com diferentes teores de cimento, com o objetivo de simular um material com diferentes valores de coesão. Os autores concluíram que o aumento da coesão reduz a contribuição das fibras para o aumento de resistência de pico do solo.

Maher \& Ho (1994) estudaram as propriedades mecânicas e hidráulicas de um compósito caulinita/fibra através de ensaios de compressão não confinada, compressão diametral, flexão e condutividade hidráulica. Foram utilizadas fibras de polipropileno, vidro e celulose. Observou-se que a inclusão aleatória das fibras aumentou a resistência e a ductilidade do compósito, sendo maior para baixos teores de umidade. Para o mesmo teor, fibras mais curtas são mais numerosas dentro da matriz e existe uma maior possibilidade delas estarem presentes na superfície de ruptura contribuindo para o aumento da resistência. Porém, após a ruptura, as fibras mais curtas são arrancadas mais facilmente, o que denota a importância de fibras mais longas quando se deseja melhorar a ductilidade e a capacidade de absorção de energia. A adição de reforços fibrosos aumentou a permeabilidade da argila estudada, sendo mais pronunciada para maiores teores de fibra.

Nataraj et al., (1996) estudaram um solo arenoso e outro argiloso reforçados com fibras de polipropileno distribuídas aleatoriamente. Com a adição de fibras não houve alterações significativas nos parâmetros de compactação do solo, porém, houve um aumento da resistência ao cisalhamento das areias, sendo o aumento mais 
pronunciado para maiores teores de fibras. Independentemente do solo estudado, foi observado que a inclusão das fibras aumentou a resistência à compressão não confinada. Tanto o solo arenoso quanto o argiloso apresentaram valores de CBR maiores com a inclusão das fibras.

Teodoro \& Bueno (1998) e Teodoro (1999) estudaram um solo argiloso e outro arenoso, reforçados com fibras de polipropileno. Com teores de $0,1 \%$ a $1 \% \mathrm{e}$ comprimentos de fibras de 10 a 30mm através de ensaios triaxiais, compressão nãoconfinada e cisalhamento direto. Foram executados painéis com solo de matriz argilosa, para estudar o padrão de fissuramento do material quando submetido a variações térmicas.

A inclusão de fibras melhorou a resistência ao cisalhamento e diminuiu a queda de resistência pós-pico do solo. No caso do solo arenoso, observou-se que as envoltórias tendem à bilinearilidade a medida que o teor e o comprimento das fibras aumentam. O efeito da inclusão de fibras nos painéis executados com o solo argiloso foi o de reduzir a dimensão das trincas, sem, no entanto, evitar o fissuramento.

Montardo (1999), Montardo et al., (2002) e Consoli et al., (2002) investigaram um solo arenoso, artificialmente cimentado e não cimentado com fibras sintéticas aleatoriamente distribuídas, e concluíram: (1) a inclusão de fibras PET ou de vidro aumentou tanto a resistência à compressão, quanto a resistência à tração da matriz cimentada, enquanto as fibras de polipropileno não proporcionaram um aumento destas duas variáveis; (2) a inclusão de fibras de polipropileno no compósito cimentado alterou o comportamento do material na ruptura, que era frágil para dúctil, sendo que a inclusão das fibras PET e de vidro não modificou o modo de ruptura; (3) a inclusão de qualquer tipo de fibra aumentou a capacidade de absorção de energia de deformação, de forma mais acentuada para comprimentos de fibra maiores; (4) a rigidez inicial não foi afetada pela inclusão das fibras PET e de vidro, porém ela é drasticamente reduzida com a inclusão de fibras de polipropileno.

Feuerharmel (2000) estudou o comportamento de três tipos de solo (uma argila, uma areia-siltosa e uma areia), artificialmente cimentados (teor de 7\% em relação ao peso de material seco) e não-cimentados, reforçados com fibras de polipropileno (teor de $0.5 \%$ ) de dois comprimentos (12 e 36mm); a distribuição das fibras na massa de solo foi aleatória. O autor concluiu que: (1) a adição de fibras de 
polipropileno provocou reduções no módulo de deformação inicial do solo, sendo que a intensidade das alterações depende do tipo e das características de cada solo. Para misturas não-cimentadas, os solos menos rígidos foram os mais afetados enquanto as alterações na areia foram pequenas; (2) quanto à resistência ao cisalhamento, o comportamento resistente dos solos não-cimentados reforçados pode ser dividido em três etapas, uma inicial, onde o comportamento é controlado basicamente pela matriz de solo, uma etapa intermediária, na qual o comportamento do material compósito é comandado juntamente pela matriz e pelos elementos de reforço, e uma etapa final, onde o comportamento do material é comandado exclusivamente pelas fibras; (3) para os solos não-cimentados, cujas deformações se distribuem por toda a amostra, as fibras constituem uma estrutura entrelaçada que impõe uma resistência às deformações radiais na amostra, aumentando assim as deformações de compressão do solo. Este efeito depende da adesão entre o solo e as fibras, sendo que para a areia, onde a adesão é inferior aos demais solos, não se observa alterações significativas na variação volumétrica; (4) para os solos cimentados, onde as deformações se concentram apenas na superfície de ruptura, as fibras atuam, em hipótese, de duas maneiras, (a) o efeito de ancoragem, proporcionado pelas fibras ancoradas nos dois lados da superfície de cisalhamento e que tende a reduzir a dilatância; (b) a redistribuição de esforços, que causa a expansão da superfície de cisalhamento, tendendo a aumentar as deformações volumétricas de expansão.

Estudos experimentais realizados por Casagrande (2001) e Casagrande \& Consoli (2002) em areia siltosa reforçada com fibras de polipropileno mostraram um crescimento constante da resistência com o aumento da deformação axial, caracterizando um comportamento elasto-plástico de enrijecimento. Segundo os autores, as fibras passaram a contribuir de forma mais significativa para o acréscimo da resistência a partir de $2,5 \%$ de deformação axial.

Heineck (2002) analisou o comportamento hidráulico e mecânico de novos materiais geotécnicos compósitos, tentando adequar suas características à utilização em barreiras hidráulicas. Foram adicionadas fibras de polipropileno de $24 \mathrm{~mm}$ e bentonita em amostras compactadas de solo, cinza, areia e caulim. Dentre as várias conclusões, cabe salientar que a adição de fibras aumentou os parâmetros de resistência ao cisalhamento (c, Ø) e a resistência ao cisalhamento pós-pico dos compósitos, principalmente a baixas tensões efetivas médias iniciais e após grandes 
deformações. Heineck \& Consoli (2002) salientam que a influência da fibra a grandes deformações, no ensaio de ring shear, deve-se provavelmente à formação de uma zona de cisalhamento que talvez ocupe toda a espessura da amostra.

Consoli et al., (2004) avaliou o comportamento de areias cimentadas e não cimentadas reforçadas com diferentes fibras. As fibras de polipropileno mudaram o modo de ruptura de frágil para dúctil, para o maior comprimento de fibra estudado (36 mm), com o aumento da capacidade de energia absorvida, fato não observado para as fibras de vidro e de poliéster, ou seja, não é possível estabelecer regras de comportamento sem o conhecimento prévio das propriedades dos materiais envolvidos.

Santos (2004) desenvolveu um equipamento de compressão confinada com medição de tensão lateral e avaliou o comportamento, sobre a trajetória de tensões Ko, de uma areia e de misturas de areia-fibra, considerando a influência da adição de fibras de diferentes comprimentos. Os resultados mostraram que: (1) a inclusão de fibras torna-se cada vez mais significativa com o aumento das tensões e que a variação do comprimento das fibras também incrementa a trajetória de tensões, sendo maior a influência quanto maior for o comprimento destas; (2) a tensão lateral diminui com a inclusão de fibras. Esta redução é mais significativa com o aumento das tensões verticais, assim como, com o aumento do comprimento das fibras; (3) a presença de fibras modifica o comportamento tensão-deformação no carregamento principalmente nas tensões iniciais e praticamente mantém a mesma forma da curva da areia sem fibras nas tensões maiores e no descarregamento e (4) os valores de Ko diminuem com a inclusão de fibras e com o aumento do comprimento das mesmas para todos os níveis de tensão tanto no carregamento quanto no descarregamento, mantendo-se praticamente constantes no carregamento e crescendo no descarregamento.

Casagrande (2005) estudou o comportamento de solos reforçados com fibras de polipropileno, submetidos a grandes deformações, que possuam características adequadas para o emprego em liners de cobertura de aterros sanitários e aterros sobre solos moles. $\mathrm{O}$ autor realizou ensaios triaxiais consolidados drenados com distintas trajetórias de tensões (compressão axial, descarregamento lateral e p' constante) e isotrópicos com aplicação de altas tensões, em amostras de areia e areia-fibra. Também foram executados ensaios do tipo ring shear (nas matrizes de areia e bentonita, com e sem reforço) e provas de carga em placa de $0.30 \mathrm{~m}$ de 
diâmetro sobre espessas camadas de areia compactada, reforçada e não reforçada com fibras. A adição de fibras ao solo aumenta tanto os parâmetros de resistência ao cisalhamento de pico, como também a resistência pós-pico das matrizes estudadas após grandes deslocamentos horizontais, sem quedas significativas de resistência pós-pico no caso da matriz arenosa. Para a matriz de alta plasticidade e altos índices de vazios, o acréscimo de resistência tende a reduzir com o aumento das deformações cisalhantes. Por outro lado, o efeito da inclusão de fibras foi mais evidente para baixas tensões efetivas médias iniciais, menores diâmetros, maiores comprimentos e maiores teores de fibras, sendo seu efeito mais pronunciado para misturas mais densas. O comportamento carga-recalque do solo arenoso foi significativamente influenciado pela adição de fibras, aumentando a capacidade de suporte deste e alterando mecanismos de ruptura.

Donato (2007) avaliou a distribuição de tensões em um solo arenoso reforçado com fibras de polipropileno através de ensaios de prova de carga em placa circular de $0.30 \mathrm{~m}$ de diâmetro, com medidas diretas de tensão pelo uso de células de tensão total. Além disso, utilizou-se o método dos elementos finitos (MEF) para simular numericamente a distribuição de tensões dentro de câmaras de calibração. $\mathrm{O}$ autor concluiu que o comportamento carga-recalque da areia e das areias reforçadas é similar no início do carregamento, até o momento em que a mobilização das fibras inseridas na matriz se mostra mais efetiva, a partir de certo nível de recalque e carga aplicada.

Consoli \& Casagrande (2009) estudaram o efeito da densidade relativa da areia reforçada com fibras de polipropileno submetidas a ensaios de placa, concluindo que o efeito de inclusão das fibras pode ser mais pronunciado para densidades mais altas. O reforço da areia tem a capacidade de aumentar sua resistência. Este material compósito poderia ser utilizado em terraplenes como parte de revestimentos de aterros de resíduos, os quais podem sofrer maiores assentamentos diferenciais.

Girardello (2010) avaliou o comportamento mecânico de uma areia não saturada, com e sem reforço de fibras de polipropileno, através de ensaios de placa em densidade relativa de $50 \%$ e $90 \%$; ensaios triaxiais e ensaios de sucção. O melhor resultado foi obtido para o ensaio de placa realizado na maior densidade relativa. 
Quanto aos ensaios de sucção, notou-se que a inclusão das fibras não ofereceu nenhuma influência na magnitude da resistência apresentada pela sucção.

Quanto aos ensaios de placa, a inclusão aleatória das fibras confere ao material uma melhoria no comportamento carga-recalque, com influência na mudança dos mecanismos de ruptura. No início do ensaio, o comportamento cargarecalque não difere para o solo reforçado e sem reforço. A diferença é perceptível a partir do momento em que a mobilização das fibras começa a se mostrar mais efetiva, que ocorre somente após um nível de recalque e carga aplicada.

Lirer (2012) estudou o comportamento de uma areia com pedregulho misturada com fibras de polipropileno chegando a concluir que a adição das fibras ao material oferece uma maior influência ao material para baixas tensões confinantes.

Para grandes deformações, o comportamento resistente do material com reforço e sem reforço é similar, isto quer dizer que a adição das fibras à areia com pedregulhos não contribui positivamente à resistência do material quando ele sofre grandes deformações.

Parodi et al., (2012) estudou o comportamento mecânico de solos não reforçados e reforçados com fibras de polipropileno, submetidos a solicitações de extensão. Utilizou um equipamento para ensaios triaxiais de extensão maior que os convencionais do tipo Bishop e Wesley. Seus resultados mostraram que nos ensaios de extensão a adição das fibras ao solo não aumentou a resistência à tração do material e ainda geram uma queda nessa resistência. Portanto, na aplicação dos solos reforçados com fibras de polipropileno, em diferentes projetos geotécnicos, somente é garantido o bom desempenho do material compósito quando submetido à força de compressão.

Costas et al., (2013) estudaram os parâmetros de resistência ao cisalhamento de areias (com diferentes tamanhos médios de grãos) com reforço de fibra orientada aleatoriamente. $\mathrm{O}$ teor de fibra variou de $0,1 \%$ a $0,5 \%$ em volume. Fizeram-se ensaios de cisalhamento direto para determinar os parâmetros na resistência pico e residual das areias com e sem reforço.

Os resultados mostraram que o reforço melhorou significativamente a resistência residual da areia fina em estado medianamente denso, enquanto nas areias em estado muito denso o incremento da resistência residual foi insignificante. Concluiu que o acréscimo da resistência pico e residual depende fortemente da 
finura da areia, o teor de fibra e um estado denso. As dimensões relativas dos grãos da areia e as fibras tem um efeito importante no comportamento induzido pela adição da fibra.

Diambra \& Ibraim (2015) modificaram o modelo constitutivo continuo proposto por Diambra et al., (2013) com base a ensaios de compressão triaxial feitos em duas areias reforçadas com fibras de polipropileno de diferentes relações de aspecto. Concluíram que o comprimento real da fibra precisa ser pelo menos 10 vezes o tamanho médio do grão para garantir o acionamento do mecanismo de interação fibra-grão. Solos granulares mais finos geram interações muito mais eficazes, enquanto, dependendo do tamanho do grão, o início do mecanismo de interação requer proporções de fibra entre 10 e 100.

Eldesouky et al., (2016) fizeram ensaios de cisalhamento direto em 108 amostras para investigar o efeito do teor de fibras, densidade relativa, tensão normal e teor de umidade na resistência ao cisalhamento e comportamento volumétrico de areia reforçada com fibra. O estudo concluiu que, a adição de fibra incrementa a resistência ao cisalhamento e aumenta o comportamento volumétrico dilatante, enquanto o incremento do teor de umidade reduz a contribuição da fibra na resistência de pico e pós pico.

Chegenizadeh et al., (2018) estudaram o efeito da fibra sobre a liquefação de sedimentos de baixa plasticidade realizando uma série de testes triaxiais cíclicos. Os resultados mostraram que o aumento do teor de fibra reduziu o risco de liquefação. Além disso, notou-se que o aumento do comprimento da fibra de $5 \mathrm{~mm}$ para $10 \mathrm{~mm}$ e $15 \mathrm{~mm}$, respectivamente, aumentou a resistência ao cisalhamento dos espécimes. Com o aumento da densidade relativa, a resistência de uma amostra reforçada é mais pronunciada. Finalmente, investigações sobre o efeito da pressão de confinamento efetiva na resistência das amostras reforçadas mostraram que o aumento da pressão de confinamento efetiva $\left(\sigma_{3}^{\prime}\right)$ incrementou a possibilidade de liquefação das amostras pela supressão da dilatância.

Li et al., (2018) estudaram a influência de 3 tipos de fibras naturais e uma sintética (polipropileno) nos solos calcários mediante ensaios de compressão não confinada e compressa triaxial, os resultados mostraram que o reforço incremento significativamente a coesão e ligeiramente o ângulo de atrito para todos os tipos de fibra, sendo a fibra de polipropileno a melhor. 
Nesta revisão observou-se a evolução do conhecimento sobre os solos fibroreforçados, as vezes as conclusões são discordantes sobre a influência da adição das fibras sobre as propriedades dos solos e também não existe muita informação sobre o efeito da fibra na variação da poropressão em solos submetidos a condições não drenadas, antecedentes que são importantes quando se pretende trabalhar com rejeitos de mineração.

Pode-se concluir nesta parte que existem alguns comportamentos que são gerais, além dos diferentes tipos de solo e fibra, a maioria dos pesquisadores concordam em que a adição de fibras aumenta a resistência ao cisalhamento, muda o comportamento volumétrico de frágil a dúctil e que aumenta a capacidade de absorção de energia de deformação. A seguir se faz uma revisão sobre as propriedades dos solos que são afetadas pela adição de fibras destacando os pontos de vista contrários segundo os resultados obtidos pelos pesquisadores.

\subsection{6.}

\section{Influência da adição de fibras nas propriedades dos solos}

Neste item são citadas as pesquisas que descrevem as mudanças ocorridas no comportamento mecânico do solo com reforço de fibras. Estas mudanças são relacionadas à compactação, resistência, deformabilidade, modo de ruptura, variação volumétrica, rigidez inicial e condutividade hidráulica, destacando se as pesquisas que coincidem nos comportamentos ou apresentam resultados diferentes.

\subsubsection{1. Compactação}

Al Wahab \& Al-Qurna (1995) avaliaram os efeitos da inclusão de vários teores de fibra $(0 ; 0,5 ; 1$ e $2 \%$ em peso do solo seco) na curva de compactação de uma argila. Encontrou-se um decréscimo da densidade e um acréscimo na umidade ótima para a adição de $2 \%$ de fibra, considerados não muito significativos.

Bueno et al., (1996) observaram o mesmo comportamento para um solo arenoso e argiloso, em ambos os casos, a densidade máxima não sofreu alterações com a inclusão de fibras.

Vários outros autores relataram também não ter encontrado nenhuma alteração significativa com a inclusão de fibras (Maher \& Ho, 1994; Ulbrich, 1997; Casagrande, 2001; Heineck, 2002). 


\subsubsection{2. \\ Resistência ao cisalhamento de pico}

Bueno et al., (1996) realizaram um estudo comparativo entre um material granular e um coesivo, observando que os solos coesivos são menos sensíveis ao aumento do comprimento das fibras. Análises baseadas em ensaios triaxiais revelaram um acréscimo no ângulo de atrito com a adição do reforço, sendo este maior quanto maior for a quantidade de fibras.

Vários autores constataram um aumento da resistência de forma linear com o aumento da quantidade de reforço (Gray \& Ohashi, 1983; Gray \& Al-Refeai, 1986), por outro lado, outros constataram um aumento não linear (Jewell \& Wroth, 1987, Shewbridge \& Sitar, 1989; Teodoro, 1999).

O aumento do ângulo de atrito e do intercepto coesivo com a inclusão de fibras e com o aumento do teor de fibras também foi relatado por diversos pesquisadores (Gray \& Ohashi, 1983; Bueno et al., 1996; Nataraj et al., 1996; Stauffer \& Holtz, 1996; Heineck (2002). Porém, Teodoro (1999) e Casagrande (2001) observaram somente o aumento da parcela coesiva de uma areia siltosa reforçada, sem alterações significativas no ângulo de atrito.

Montardo (1999) constatou o aumento do ângulo de atrito de areia uniforme cimentada e não cimentada reforçada com vários tipos de fibra. Acréscimos da coesão somente foram verificados para a areia não cimentada reforçada com fibras.

Resultados semelhantes também foram obtidos por Heineck (2002) para uma areia reforçada com fibras. Não foi constatada pelos autores a existência de uma tensão de confinamento crítica para estes materiais.

Por outro lado, Heineck (2002) constatou uma bi-linearidade na envoltória de ruptura de uma areia siltosa reforçada com fibras. A parte inicial da envoltória possui um intercepto coesivo praticamente inexistente e um ângulo de atrito que supera o dobro do valor correspondente ao solo sem reforço. Já na segunda parte da envoltória, acima da tensão confinante crítica, o ângulo de atrito é semelhante ao do solo sem reforço, entretanto, houve um acréscimo razoável do intercepto coesivo.

A bi-linearidade foi também observada por vários autores (Gray \& Ohashi, 1983; Gray \& Al Refeai, 1986; Maher \& Gray, 1990; Stauffer \& Holtz, 1996; Morel \& Gourc, 1997). Foi observado ainda que quanto menor for a rugosidade ou 
aderência da interface solo-fibra, maior é a tensão de confinamento crítica. Fibras mais rugosas tendem a ser mais efetivas no aumento da resistência.

\subsubsection{3.}

\section{Resistência ao cisalhamento de pós-pico}

Praticamente todos os trabalhos que analisaram o comportamento de solos reforçados em termos da resistência concluíram que a adição de fibras reduz a queda da resistência pós-pico (Gray \& Ohashi, 1983; Gray \& Al-Refeai, 1986; Ranjan et al., 1996; Donato et al., 2004; Casagrande, 2005; Donato, 2007).

\subsubsection{4.}

\section{Variação Volumétrica}

A adição de fibras aumenta as deformações volumétricas de compressão na ruptura, segundo Stauffer \& Holtz (1996), este aumento é mais pronunciado para areias uniformes do que para areias bem graduadas, ambas com mesmo diâmetro médio $\left(\mathrm{D}_{50}\right)$. $\mathrm{O}$ aumento da compressibilidade do solo com a inclusão de fibras também foi observado por Bueno et al., (1996). Segundo Shewbridge \& Sitar (1989), a deformação volumétrica aumenta com o acréscimo da quantidade de reforço, porém, de forma não linear, similar ao observado por Nataraj et al., (1996).

Existe um consenso em que solos aumentam a deformação volumétrica com a adição de fibras.

\subsubsection{5.}

\section{Deformabilidade}

Foi observado por McGown et al., (1988), através de um ensaio de placa de pequenas dimensões, uma grande parcela de deformação recuperada com o descarregamento, referente a $20 \%$ da deformação total imposta. McGown et al., (1988) para areias e Maher \& Ho (1994) e Nataraj et al., (1996), para argilas, relataram um aumento no módulo de deformação, tanto maior quanto maior o teor de fibras. Contrariamente, Ulbrich (1997) obteve uma redução do módulo com a inclusão de fibras, para areias cimentadas e não cimentadas.

Stauffer \& Holtz (1996) relataram que a adição de fibras aumenta as deformações volumétricas de compressão na ruptura, sendo este aumento mais 
pronunciado para uma areia mal graduada do que para uma graduada (ambas com mesmo diâmetro $\mathrm{D}_{50}$ dos grãos).

Para Heineck (2002), a taxa de deformação onde as fibras passam a contribuir de forma mais significativa para o acréscimo de resistência ao cisalhamento depende do tipo de matriz.

Consoli et al., (2007a) estudaram o desempenho de uma areia reforçada com fibras de polipropileno de diferentes comprimentos, submetida a grandes deformações cisalhantes mediante a execução de ensaios de ring shear.

Foi observado que quanto maior é a deformação cisalhante nos ensaios, maior vai ser a quantidade de fibras rompidas, isto confere a ideia de que as fibras se alongam até que as deformações do ensaio superam a deformação de ruptura das fibras, porém as fibras sofrem deformações plásticas antes de romper.

\subsubsection{6. \\ Modo de Ruptura}

O aumento da ductilidade do solo com a adição de fibras é uma observação feita em caráter unânime pelos vários autores que avaliaram este parâmetro, sendo que com a inclusão das fibras o comportamento do material na ruptura, que era frágil, torna-se dúctil. (McGown et al., 1988; Maher \& Ho, 1993; Nataraj et al., 1996; Montardo et al., 2002; Consoli et al., 2002; Consoli et al., 2004; Girardello, 2010), sendo este aumento mais pronunciado quanto maior a quantidade de fibras.

\subsubsection{7.}

Rigidez Inicial

Para Feuerharmel (2000), a intensidade das alterações no módulo de deformabilidade depende também do tipo e das características de cada solo. Estudos realizados pelo autor em argila e areia siltosa reforçada com fibras de polipropileno indicaram grande redução do módulo, enquanto os resultados de ensaios realizados em areia reforçada mostraram pequenas alterações no módulo. Entretanto, considerando misturas cimentadas reforçadas com fibras, as reduções do módulo foram bastante acentuadas para os solos analisados. Michalowski \& Cermák (2003) observaram que a adição de uma fibra sintética em um solo arenoso causou uma queda da rigidez inicial. 


\subsubsection{8.}

\section{Condutividade Hidráulica e outras propriedades}

O aumento da condutividade hidráulica pela adição de fibras em solos argilosos é relatado por vários autores. Maher \& Ho (1994) observam um aumento na condutividade hidráulica para teores de fibra $>1 \%$ (polipropileno e vidro).

Já Al Wahab \& El-Kedrah (1995) observam um aumento da condutividade hidráulica em mais de uma ordem de grandeza para 2\% de fibra (polipropileno).

Bueno et al., (1996) relataram uma redução da permeabilidade de uma ordem de grandeza, causada pela adição de fibras a solos granulares.

Feurharmel (2000) observa que são obtidos valores de condutividade hidráulica bem mais elevados no momento em que são adicionados fibras e cimento ao material argiloso, pois com a floculação das partículas de argila, estas, que antes aderiam às fibras, passam a se aglomerar ao redor de partículas de cimento, propiciando a segregação das fibras.

Segundo Heineck (2002) para todas as matrizes estudadas, a adição de 0,5\% de fibras de polipropileno de $24 \mathrm{~mm}$ não causou mudanças significativas na condutividade hidráulica avaliada.

Curcio (2008) concluiu que a adição de $1 \%$ de fibras, além de favorecer o acréscimo da tensão de tração máxima do solo, retarda a abertura de fissuras e reduz a magnitude das mesmas, sem alterar as propriedades desejáveis na compactação e sem influenciar negativamente a condutividade hidráulica de solo quando utilizadas sob tensão confinante.

\section{4.}

\section{Rejeitos de minério de ferro e ouro fibroreforçados}

A análise dos rejeitos de mineração começou a gerar interesse na comunidade cientifica quando apesar do avanço tecnológico na disposição de rejeitos os acidentes ocorriam nas barragens de mineração. Os rejeitos de minério são subprodutos que foram submetidos a intenso desgaste físico e químico, portanto o comportamento geotécnico pode mudar quando se compara com um solo natural.

Nos itens anteriores se conseguiu obter um marco geral do comportamento dos solos quando reforçados com fibras, com esta base, diferentes pesquisadores avaliaram os rejeitos de mineração para entender como se comportam ante 
solicitações drenadas, não drenadas ou sob carregamento cíclico, mas a grande variabilidade, muitas vezes, não permite determinar comportamentos gerais.

Sob este ponto de vista, Tarazona \& Barbosa (2011) fizeram uma avaliação dos rejeitos de minério de ferro, alumínio e ouro produzidos no Brasil presentes na literatura, os aspectos avaliados foram caracterização física, parâmetros de compressibilidade obtidos de ensaios de adensamento e parâmetros de resistência obtidos de ensaios de cisalhamento direto, compressão triaxial e ensaios de campo com piezocone. Reportaram que os parâmetros de permeabilidade (k) e de coeficiente de adensamento $(\mathrm{Cv})$ dos rejeitos não apresentam uma faixa de variação muito ampla e são coerentes entre si. No entanto, em relação à resistência o comportamento é muito variável pela heterogeneidade e mineralogia destes materiais. Os ângulos de atrito efetivo dos rejeitos de mineração de ferro, em particular, se apresentaram muito variáveis, e para os rejeitos de ouro a literatura mostra diferença significativa nos valores encontrados dependendo do método de ensaio utilizado.

Pesquisas para utilizar diferentes tipos rejeitos de minério como materiais de construção são relativamente novas, pelo motivo da variabilidade, porque somente poderiam ser aplicáveis em alguns projetos e sob determinadas condições.

Como os rejeitos de minério não acostumam ter boas propriedades geotécnicas é usual realizar algum tipo de mistura com materiais de boas características ou reforçar a matriz de rejeito com geosintéticos. Em tal sentido, a seguir se faz uma revisão sobre pesquisas que utilizaram rejeitos de minério de ferro e/ou ouro reforçados com fibras de polipropileno ou misturados com solo.

Coelho (2008) estudou uma mistura de rejeito de minério de ferro fino (10\%) com argila (20\%) e rejeito de jigagem (70\%) reforçado com fibras de polipropileno para material de base em aterros rodoviários. Reportou que a adição de fibra reduziu a resistência inicial do compósito propiciando maiores efeitos de ductilidade e impondo um comportamento elasto-plástico de enrijecimento do material. A envoltória de resistência se apresentou bi-linear no qual o primeiro trecho possui um baixo intercepto coesivo mas alto ângulo de atrito enquanto o segundo trecho um alto intercepto coesivo mas o ângulo de atrito é reduzido. O autor finalmente não recomenda utilizar a mistura porque encontrou efeitos maiores de contração sob cisalhamento tornando crítico o risco de liquefação de rejeitos. 
Festugato et al., (2015) realizaram um estudo para avaliar a resposta cíclica de rejeitos de minério de ouro reforçados com fibras de polipropileno, observaram que sob condições de cisalhamento monotônicas, a adição de fibras reduzem a rigidez do material. Encontraram que sob condições cíclicas de tensão controlada, as fibras melhoraram a resposta de cisalhamento do material produzindo um material mais rígido, enquanto sob condições cíclicas de deformação controlada, nenhuma melhora foi observada e não houve efeito sobre a rigidez do material pela adição de fibra.

Consoli et al., (2017) avaliaram a durabilidade e resistência de misturas de rejeito de minério de ouro com cimento portland reforçado com fibras de polipropileno quantificando a perda de massa acumulada (ALM) das misturas após ciclos de molhagem e secagem e a variação da resistência à compressão não confinada em função do índice de porosidade/cimento. Concluíram que as inclusões de fibras reduzem notavelmente a perda de massa dos espécimes após os ciclos de molhagem/secagem, sendo mais eficazes tanto na resistência quanto na durabilidade.

Como é possível observar existe pouca literatura acerca da aplicabilidade dos rejeitos de mineração na indústria. Atualmente a maior preocupação é cumprir com os controles, a política de segurança de barragens e a qualidade do acompanhamento geotécnico para evitar os riscos de liquefação enquanto se continua alteando as barragens de mineração.

Esta pesquisa procura mostrar que pode existir uma melhora dos parâmetros de resistência ao reforçar os rejeitos utilizados na construção dos diques de alteamento adicionando fibras de polipropileno.

A certeza que uma estrutura pode resistir ainda após a ruptura é importante não somente para as mineradoras sobretudo para a sociedade em conjunto, após os imprevistos ou acidentes acontecidos nos últimos anos.

A seguir se descrevem as técnicas experimentais e os equipamentos utilizados para realizar a caraterização mecânica dos rejeitos de mineração. 


\section{3. \\ Programa Experimental}

\section{1.}

\section{Considerações gerais}

O programa experimental constou dos trabalhos realizados previamente no campo para a obtenção das amostras e aqueles realizados no laboratório para determinar a influência das fibras nos rejeitos de mineração.

Também como parte importante do programa experimental se descrevem detalhadamente os equipamentos e metodologias empregadas para realizar os ensaios de caracterização mecânica dos rejeitos de minério reforçados.

\section{2.}

\section{Fases do trabalho}

Neste item são apresentadas as fases do trabalho adotadas para o desenvolvimento da pesquisa, formada pela coleta das amostras e execução dos ensaios de laboratório.

$\mathrm{Na}$ Fase I, procurou-se encontrar empresas mineradoras que possuam estruturas de contenção de rejeitos de minério de ferro e de ouro em atividade, mostrar a proposta da tese e finalmente conseguir coletar e transportar o material para o Brasil. Também se procurou conseguir as fibras de reforço com uma empresa no Brasil (Maccaferri).

$\mathrm{Na}$ Fase II foram realizados ensaios de caracterização física e química dos rejeitos de minério. Realizaram-se também ensaios de tração nas fibras de polipropileno.

$\mathrm{Na}$ fase III foram realizados ensaios de caracterização mecânica para determinar a influência da fibra no comportamento dos rejeitos de minério.

As fases I e II são descritas no capítulo 4 e a fase III é apresentada com detalhe no capítulo 5 da presente tese.

$\mathrm{Na}$ Tabela 3.1 é apresentado um resumo das três fases incluindo o número de ensaios realizados. 
Tabela 3.1. Fases de Trabalho

PROGRAMA EXPERIMENTAL

(136)

\begin{tabular}{|c|c|c|c|c|c|c|}
\hline & $\Gamma$ & & & \multicolumn{3}{|c|}{ FASE III } \\
\hline TESE & \multicolumn{3}{|c|}{$\begin{array}{c}\text { CAPÍTULO } 4 \\
\text { (82) }\end{array}$} & \multicolumn{3}{|c|}{$\begin{array}{c}\text { CAPÍTULO } 5 \\
(54)\end{array}$} \\
\hline $\begin{array}{l}\text { REJEITO DE } \\
\text { MINÉRIO DE } \\
\text { FERRO }\end{array}$ & $\begin{array}{l}\text { Coleta no } \\
\text { dique de } \\
\text { alteamento }\end{array}$ & $\begin{array}{l}5 \text { caixas } \\
\text { de } 5 \mathrm{~kg}\end{array}$ & $\begin{array}{c}\text { Caraterização } \\
\text { Física (24) } \\
\text { Caraterização } \\
\text { Química (11) } \\
\text { Analisador de } \\
\text { Energia } \\
\text { dispersiva (2) }\end{array}$ & $\begin{array}{l}\text { Ensaios } \\
\text { triaxiais }\end{array}$ & $\begin{array}{l}\text { Ensaios } \\
\text { triaxiais }\end{array}$ & $\begin{array}{l}\text { Ensaios de } \\
\text { Cisalhamento }\end{array}$ \\
\hline $\begin{array}{l}\text { REJEITO DE } \\
\text { MINÉRIO DE } \\
\text { OURO }\end{array}$ & $\begin{array}{l}\text { Coleta na } \\
\text { pilha de } \\
\text { rejeitos } \\
\text { compactados }\end{array}$ & $\begin{array}{c}30 \\
\text { amostr } \\
\text { as de } \\
1 \mathrm{~kg}\end{array}$ & $\begin{array}{c}\text { Ensaio de } \\
\text { Proctor } \\
\text { Normal (8) } \\
\text { Ensaios de } \\
\text { Permeabilidad } \\
\text { e (2) }\end{array}$ & $(16)^{*}$ & $(16)^{*}$ & $(20)^{*}$ \\
\hline $\begin{array}{c}\text { FIBRAS DE } \\
\text { POLIPROPILENO }\end{array}$ & $\begin{array}{c}\text { Entregues } \\
\text { por empresa } \\
\text { fabricante }\end{array}$ & $\begin{array}{c}600 \mathrm{~g} \\
\text { de fibra }\end{array}$ & $\begin{array}{c}\text { Ensaios de } \\
\text { Tração } \\
\text { (35) }\end{array}$ & - & - & - \\
\hline $\begin{array}{c}\text { INTERAÇÃO } \\
\text { MATRIZ - FIBRA }\end{array}$ & - & - & - & Ensa & $\begin{array}{r}\text { Microscop } \\
\text { Varre } \\
(2\end{array}$ & $\begin{array}{l}\text { Eletrônica de } \\
\text { ra }\end{array}$ \\
\hline
\end{tabular}

( ) número de ensaios

( )* ensaios não reforçados e reforçados

\section{3.}

\section{Equipamentos utilizados e metodologia empregada}

Este capítulo descreve os equipamentos e metodologias empregadas para realizar os ensaios de laboratório necessários para a compreensão do comportamento de pico ou de strain hardening, pós pico e residual dos rejeitos de minério de ferro e ouro não reforçados e reforçados com fibras de polipropileno.

Para descrever o comportamento de pico e pós pico, ensaios de compressão triaxial convencional com adensamento isotrópico drenado (CID) e não drenado (CIU) foram realizados com velocidade de deslocamento vertical constante.

Os corpos de prova não reforçados e reforçados foram submetidos a tensões efetivas de confinamento de 50,100, 200 e $400 \mathrm{kPa}$ com a finalidade de capturar o comportamento para baixas e altas tensões.

No intuito de descrever o comportamento residual, foram realizados ensaios de cisalhamento direto convencional com plano cisalhado e superfície polida nas amostras não reforçadas e reforçadas empregando tensões normais iniciais de adensamento de 25, 50,100, 200 e $400 \mathrm{kPa}$. Os rejeitos de minério amolgados foram 
reconstituídos no Laboratório da Pontifícia Universidade Católica do Rio de Janeiro.

\subsection{1.}

\section{Ensaios Triaxiais}

O uso do equipamento triaxial começou já na fase de moldagem dos corpos de prova porque se pretendeu diminuir o manuseio e o tempo entre a mistura soloágua-fibra, a compactação, e a colocação no pedestal triaxial.

No caso dos rejeitos de ferro, foram colocados dentro de um molde tripartido subdividido em 5 camadas. Utilizou-se como medida de controle a densidade relativa de 65\% indicada por Rezende (2013) como ótima para diques de alteamentos de rejeitos de minério de ferro. A moldagem foi feita mediante o método moist tamping. No caso do rejeito de minério de ouro realizou-se a compactação do material no molde de Proctor normal na densidade máxima seca à umidade ótima, porque nas pilhas deste rejeito, o material é compactado.

Posteriormente, a amostra cilíndrica foi retirada do molde e talhada para obter 3 corpos de prova. Nesse sentido, somente a moldagem do rejeito de minério de ferro foi feita diretamente sobre o pedestal de uma prensa triaxial convencional. A distribuição de válvulas, localizadas ao redor do pedestal, é mostrada na Figura 3.1.

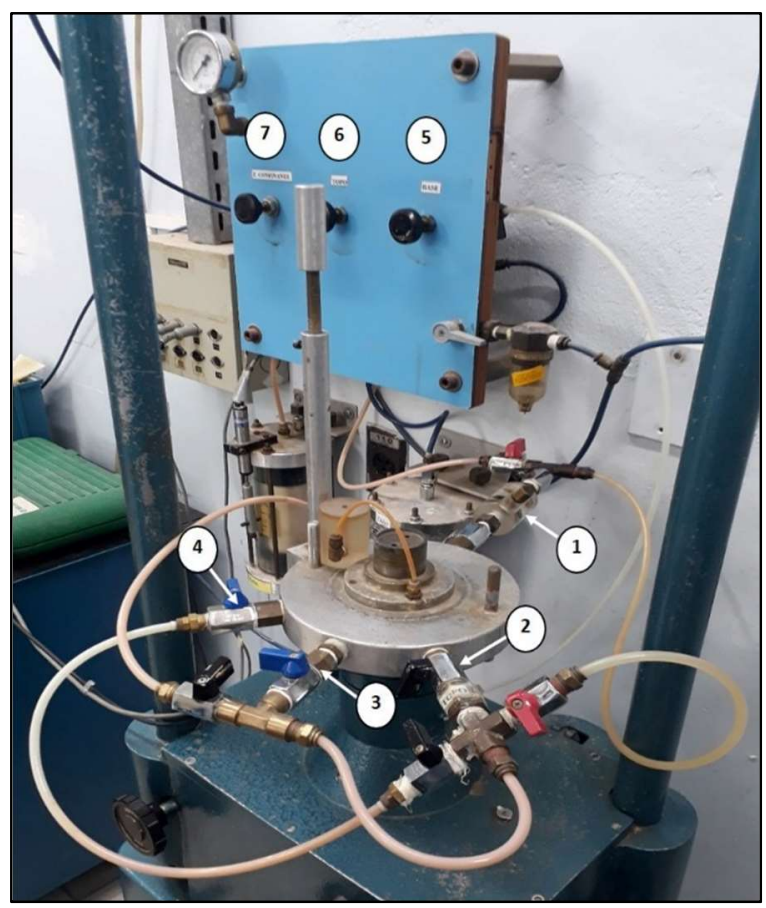

1. Transdutor de pressão.

2. Válvula de ingresso/saída topo.

3. Válvula de ingresso/saída base.

4. Válvula de ingresso/saída pressão confinante.

5. Válvula reguladora de pressão de base.

6. Válvula reguladora de pressão de topo.

7. Válvula reguladora de pressão. confinante.

Figura 3.1. Distribuição de válvulas no equipamento triaxial 
Após a moldagem do corpo de prova, colocou-se a câmara de pressão que contém no interior à célula de carga, e no exterior, o transdutor de deslocamento.

Trabalhou-se com um transdutor de pressão para controlar tanto as pressões da base, topo e confinante assim como realizar as medidas de poropressão no interior da amostra. $\mathrm{O}$ transdutor de pressão conecta com o pedestal mediante uma válvula que permite a entrada e a saída de agua do interior da amostra. Durante as fases de saturação, adensamento e cisalhamento, os dados foram registrados e armazenados pelo sistema de aquisição de dados. A seguir são apresentadas as características dos equipamentos e a instrumentação utilizada.

\subsubsection{1.}

\section{Equipamento, instrumentação, aquisição de dados, acessórios}

\section{Prensa Triaxial}

Os ensaios triaxiais foram executados em uma prensa triaxial Wykeham Farrance, com capacidade de $10000 \mathrm{~kg}$, cujo sistema de engrenagens permite a seleção da taxa de deslocamento constante, que pode variar de 0,00016 a $4 \mathrm{~mm} / \mathrm{min}$.
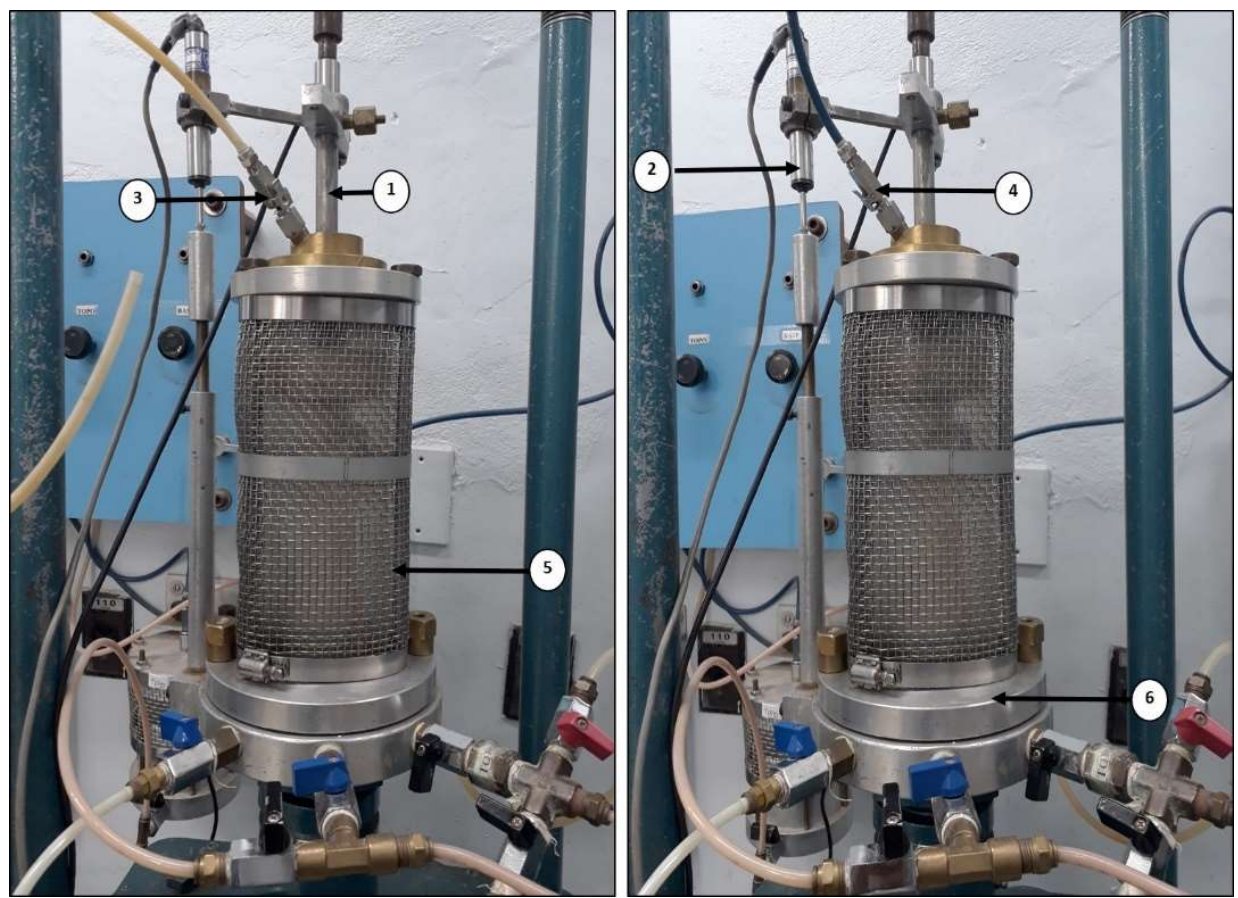

1. Haste da célula de carga.

2. Transdutor de deslocamento tipo LSCDT.

3. Válvula com função de despressurização.

4. Válvula com função de ingresso da pressão confinante.

5. Câmara triaxial acrílica com proteção externa de malha de aço.

6. Pedestal de aço.

Figura 3.2. Câmara triaxial 
A câmara triaxial usada, adequada para amostras de 3,8 cm de diâmetro, tem um corpo acrílico que suporta uma pressão máxima de confinamento de $1000 \mathrm{kPa}$.

A câmara é apoiada sobre um pedestal de aço pelo qual são realizados o enchimento da câmara, as medidas de poropressão e tensão confinante. $\mathrm{Na}$ tampa superior existem dois furos, um central por onde passa a haste da célula de carga e outro para despressurização e ingresso da pressão de confinamento.

\section{Sistema Regulador de Pressão}

Para a aplicação da pressão confinante e da contrapressão, utilizou-se um sistema de ar comprimido controlado por um painel de válvulas reguladoras de pressão ligadas à rede de ar comprimido do laboratório que fornece uma pressão máxima na linha de $1000 \mathrm{kPa}$. O controle é realizado manualmente pelo operador da prensa que regula a pressão de ar segundo as leituras do transdutor de pressão.

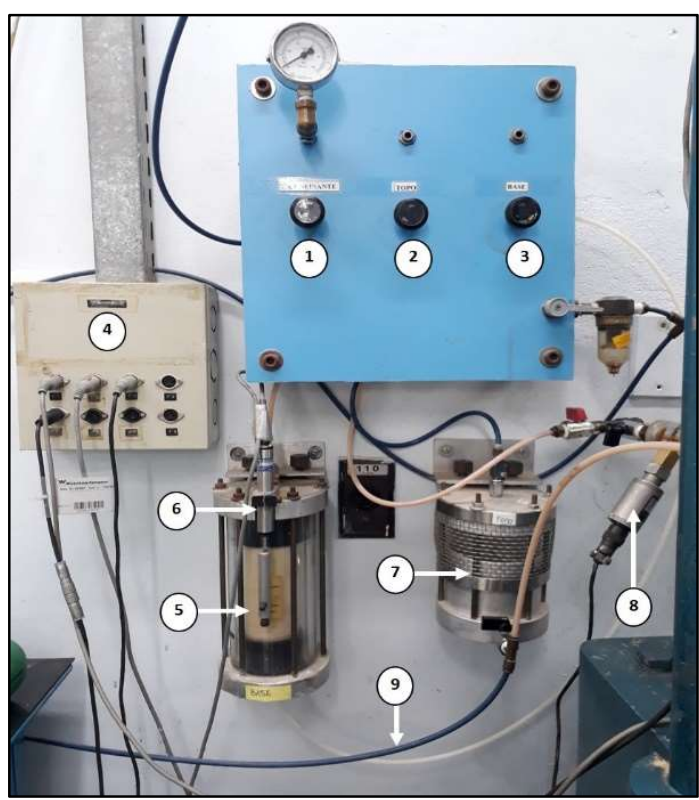

1. Válvula reguladora de pressão confinante.

2. Válvula reguladora de pressão de topo.

3. Válvula reguladora de base.

4. Painel de conexão ao sistema de dados.

5. Medidor de Variação Volumétrica (MVV).

6. Transdutor de deslocamento do MVV.

7. Reservatório de Topo.

8. Transdutor de pressão.

9. Linha de agua destilada.

Figura 3.3. Distribuição de válvulas no equipamento triaxial

O sistema, mostrado na Figura 3.3, possui três válvulas Watson Smith, que trabalham na faixa de $12-820 \mathrm{kPa}$, que alcançam a pressão máxima de $1030 \mathrm{kPa}$, sendo que uma das válvulas serve para aplicação da pressão de ar no topo da câmara triaxial, o que confere a pressão confinante, e as outras duas para aplicação de contrapressão na base e no topo do corpo de prova, respectivamente.

Antes da aplicação da pressão confinante, a câmara triaxial é totalmente preenchida com água com a finalidade de que a pressão de ar aplicada seja 
transmitida diretamente à agua de confinamento e ao corpo de prova submerso. Para a contrapressão, o ar comprimido foi aplicado diretamente ao medidor de variação de volume (MVV), que transmitia a pressão ao corpo de prova.

\section{Transdutores de Força, pressão e deslocamento}

A medição da força aplicada foi feita através de uma célula de carga de $5 \mathrm{kN}$ de capacidade e precisão de $0,1 \mathrm{~N}$ instalada no interior da câmara triaxial. As medidas de poropressão na base do corpo de prova foram efetuadas com um transdutor de pressão com resolução de $0,01 \mathrm{kPa}$ e $1034 \mathrm{kPa}$ de capacidade máxima.

O deslocamento axial foi monitorado com um transdutor de deslocamento resistivo, tipo LSCDT (Linear Strain Conversion Displacement Transducer) de 25,4 mm de faixa de deslocamento com resolução de 0,01 $\mathrm{mm}$. Este LSCDT foi instalado do lado externo da câmara, preso à haste da célula de carga, com o objetivo de medir o deslocamento relativo da câmara triaxial.

\section{Medidores de Volume}

A variação volumétrica foi medida com um transdutor de variação de volume do tipo Imperial College, fabricado na PUC-Rio (De Campos, 1985), que consiste em duas câmaras limitadas por diafragmas tipo Bellofram fixados a um cilindro maciço de PVC, como mostra a Figura 3.4.
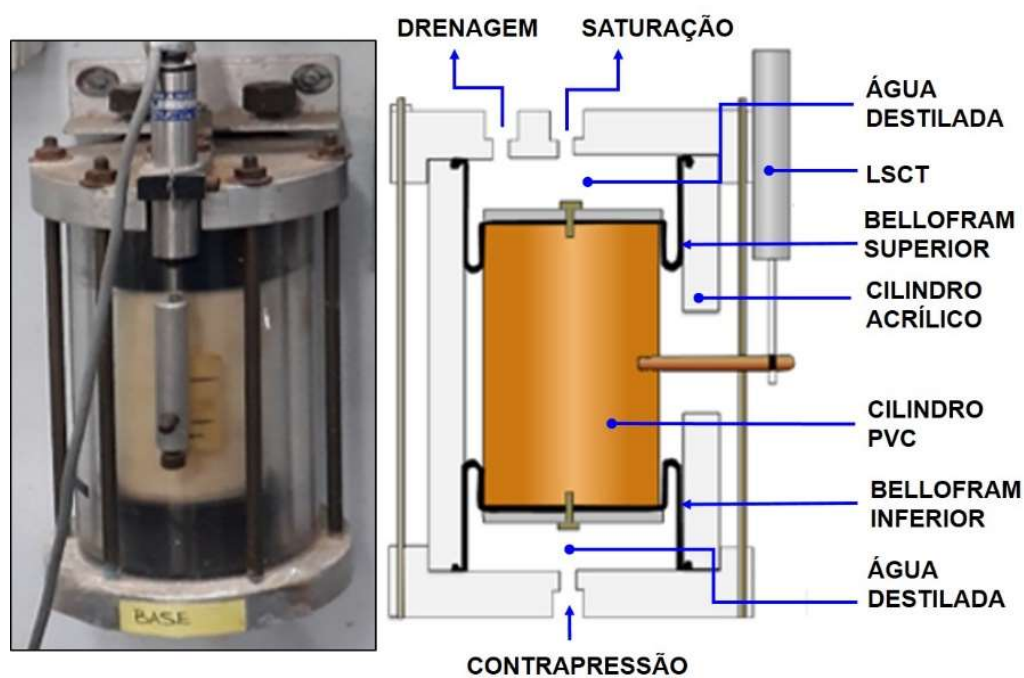

Figura 3.4. Medidor de variação de volume tipo Imperial College (adaptado de De Campos, 1985) 
A câmara inferior fornece a contrapressão enquanto a câmara superior é conectada ao sistema de drenagem do corpo de prova, o diafragma entre elas movimenta-se com a entrada ou saída de água do corpo de prova.

Quando se aplica a contrapressão, a borracha Bellofram inferior empurra o cilindro de PVC transmitindo a pressão para a câmara superior e por efeito para o corpo de prova.

O movimento do cilindro de PVC é medido por um transdutor de deslocamento previamente calibrado para relacionar a variação elétrica com uma variação volumétrica e assim obter a variação do volume da amostra.

O MVV utilizado tem uma capacidade máxima de $100 \mathrm{~cm}^{3}$, com resolução de $0,01 \mathrm{~cm}^{3}$, e utiliza um transdutor resistivo de deslocamento das mesmas características do que o tradutor na câmara triaxial.

\section{Sistema de aquisição de dados}

O sistema de aquisição de dados usado é do tipo QuantumX do fabricante HBM, com amplificador universal MX840A e composto por 3 módulos sincronizados de 8 canais cada. O software utilizado para aquisição dos sinais foi CatmanEasy também da HBM. A Figura 3.5 mostra o sistema de aquisição de dados empregado.

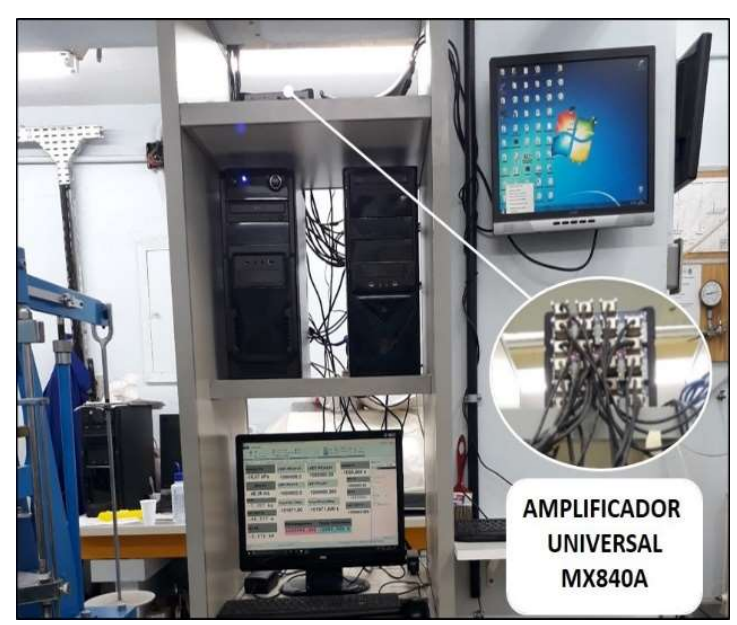

Figura 3.5. Sistema de Aquisição de dados

\section{Acessórios}

As membranas de látex utilizadas foram importadas, foi verificada a continuidade superficial do látex como se descreve no item 3.2.2.3. 
O papel filtro empregado foi previamente cortado antes de cada ensaio, sendo colocado na base e no topo do corpo de prova. As pedras porosas foram previamente saturadas e mantidas em água destilada até a montagem do ensaio.

O molde tripartido, mostrado na Figura 3.6, foi limpo após cada moldagem pois partículas finas podem ficar aderidas e rasgar a membrana. O molde consta de três peças de aço e uma abraçadeira.

\subsubsection{2. \\ Metodologia empregada}

\section{Verificação da estanqueidade}

O sistema de transmissão de pressão precisa de uma minuciosa revisão das linhas por onde passará a água, normalmente pontos de vazamento não são visíveis a olho nu sejam nas tubulações ou nos contatos entre válvula-tubulação, portanto foi necessário colocar uma pressão de $400 \mathrm{kPa}$ passando pelas linhas para verificar que não existem vazamentos.

Também realiza-se com detalhe, antes de cada ensaio, uma limpeza do pedestal, pois partículas finas podem ficar embaixo da borracha da base da câmara, impedindo a completa estanqueidade da câmara triaxial e produzindo vazamento na base durante o ensaio.

\section{Saturação do sistema}

Confirmada a estanqueidade procede-se à saturação das linhas por água mediante percolação desta desde o reservatório de água destilada até os reservatórios de base e topo, retirando assim todas as bolhas de ar do sistema.

\section{Verificação da continuidade da membrana}

Previamente a qualquer ensaio foi feita a verificação da continuidade superficial da membrana empregando para isso um cano de 1" de diâmetro com orifícios em diferentes posições ao longo do seu comprimento com uma válvula no extremo, como mostra a Figura 3.6.

O tubo furado era colocado dentro da membrana que era presa nos extremos com o-rings, posteriormente, se abria a válvula, ingressando uma pressão de ar até 
que a membrana se expandisse em um volume razoável, depois a válvula era fechada.

Finalmente, colocava-se o conjunto dentro de um recipiente com água, se a membrana não liberasse bolhas de ar enquanto estava submersa, a membrana era confiável por não apresentar furos.
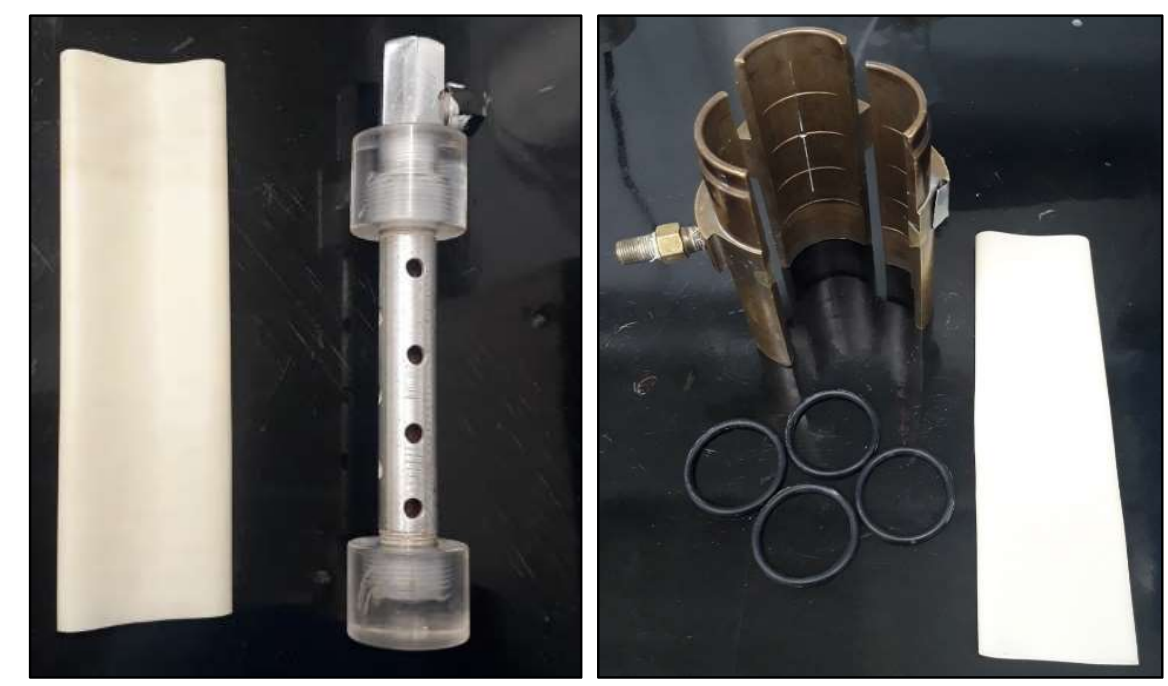

Figura 3.6. Verificação da continuidade da membrana de látex

\section{Moldagem dos corpos de prova}

O processo de moldagem para o rejeito de minério de ferro foi igual para o rejeito não reforçado e reforçado. Para a pesagem das fibras e do rejeito foram utilizadas balanças de precisão de $0,001 \mathrm{~g}$ e $0,01 \mathrm{~g}$, respectivamente.

O processo de mistura da matriz com as fibras consistiu em colocar primeiro uma camada fina de rejeito desfiando manualmente sobre ele as fibras, a seguir se colocou outra camada de rejeito, finalmente se espalhava o teor de agua correspondente à umidade para alcançar a densidade relativa. Empregou-se uma espátula para misturar os componentes.

Visualmente se conseguiu uma distribuição homogênea das fibras. A moldagem foi feita utilizando um molde tripartido de aço de 3,93 $\mathrm{cm}$ de diâmetro interno e 7,86 cm de altura efetiva, mostrado na Figura 3.6.

A amostra foi compactada em 5 camadas para assegurar a densidade de compactação determinada previamente.

A Figura 3.7 mostra os principais passos para a moldagem do corpo de prova. 

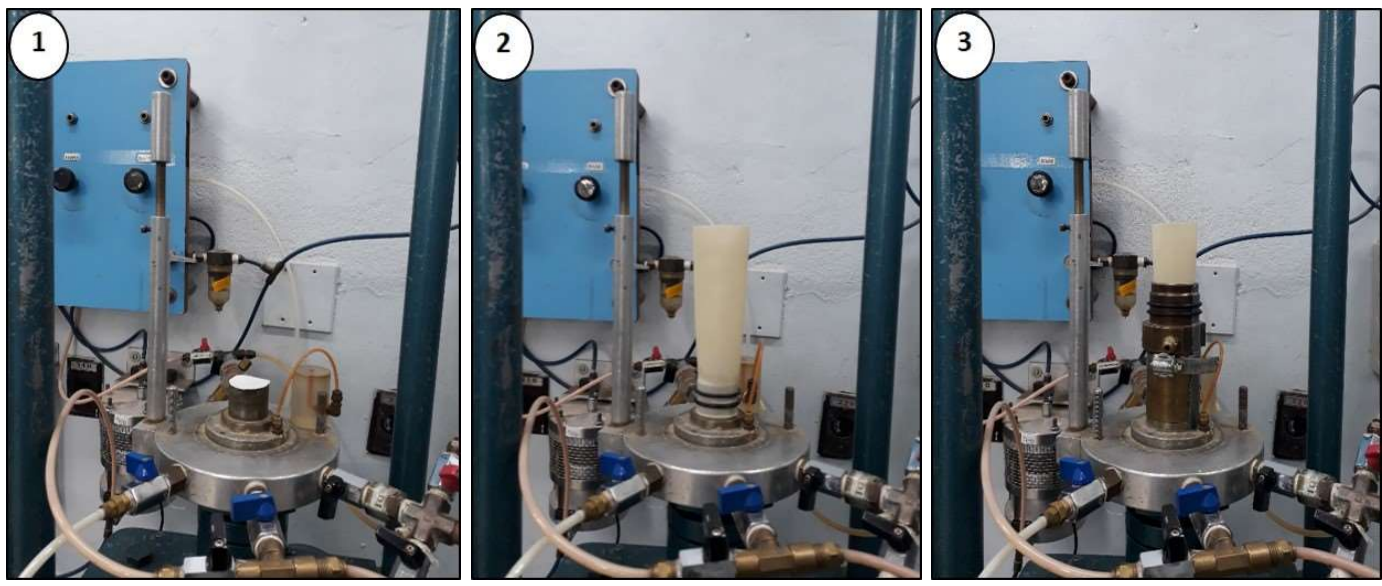

Ư
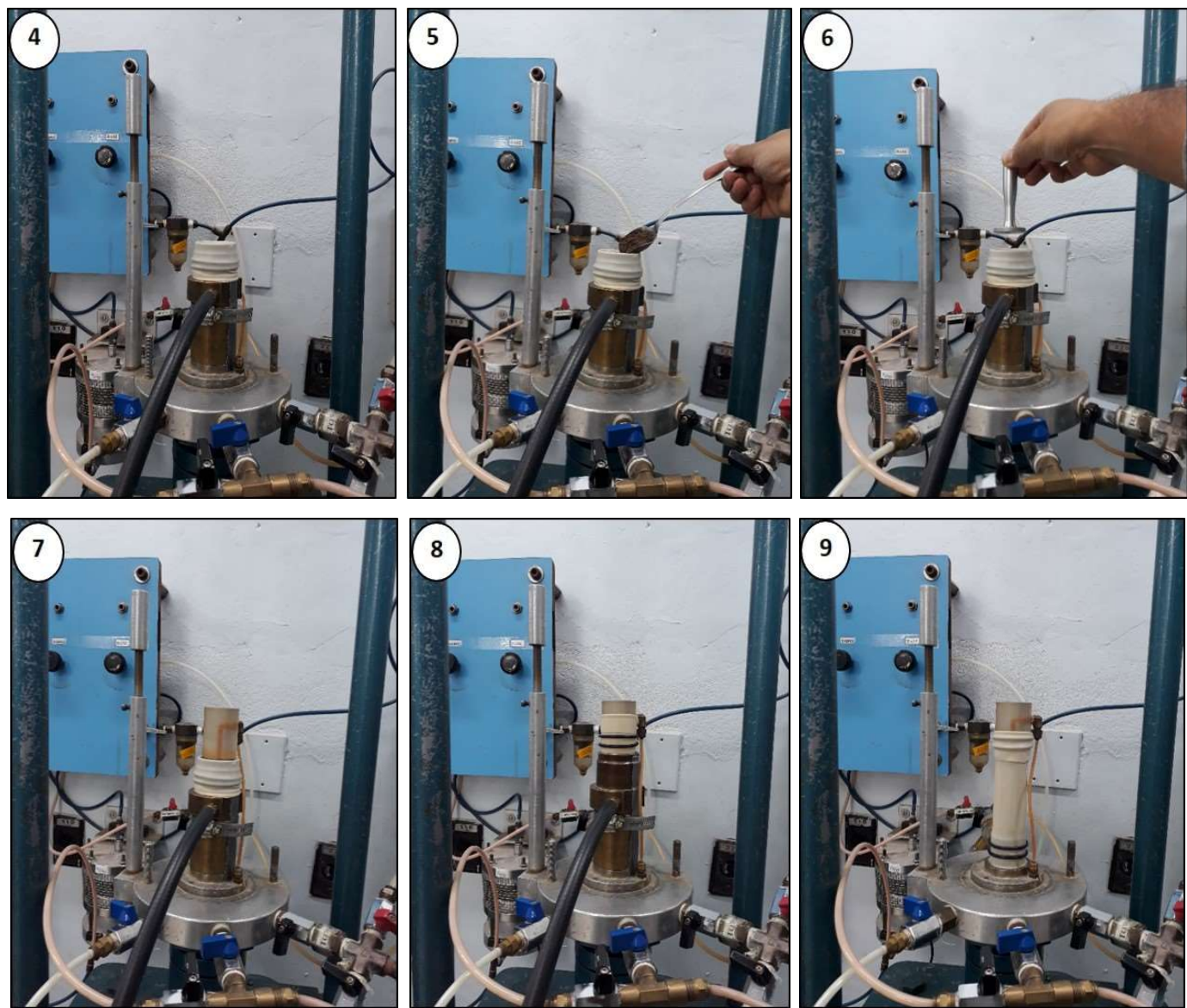

1. Colocação da pedra porosa da base e papel filtro.

2. Colocação de membrana de látex e o-rings da base.

3. Montagem do molde tripartido com abraçadeira e o-rings do topo.

4. Aplicação de vácuo entre o molde tripartido e a membrana de látex.

5. Colocação do rejeito de minério de ferro.

6. Compactação manual até que a densidade atinja a altura da camada correspondente.

7. Colocação de papel filtro, pedra porosa e drenagem do topo (top-cap).

8. Colocação da membrana de látex no top-cap presa por o-rings do topo.

9. Desmontagem do molde tripartido.

Figura 3.7. Sequência da montagem do corpo de prova Rejeito de minério de ferro 
Primeiro colocava-se a membrana de látex sendo prendida com os o-rings da base, depois colocava-se o molde tripartido no pedestal do equipamento triaxial que possui a pedra porosa na base protegida com o papel filtro, aplicava-se uma pressão de vácuo para eliminar o ar presente entre a parede interna do molde e a membrana. Depois se procedeu a colocar cada camada de rejeito não reforçada ou reforçada, verificando a densidade mediante o controle de cada camada até encher o molde. Finalmente, colocava-se o papel filtro, a pedra porosa e o top-cap, se retirava o vácuo e a membrana era presa ao top-cap com o-rings. No caso do rejeito de minério de ouro, realizou-se a compactação do rejeito não reforçado ou reforçado no molde de Proctor normal na densidade máxima seca aparente e com teor de umidade ótimo. Para a mistura rejeito-fibra realizou-se o mesmo processo descrito para o rejeito de ferro. A Figura 3.8 mostra o processo de mistura do rejeito de minério de ouro antes de ser colocado no molde de Proctor normal.
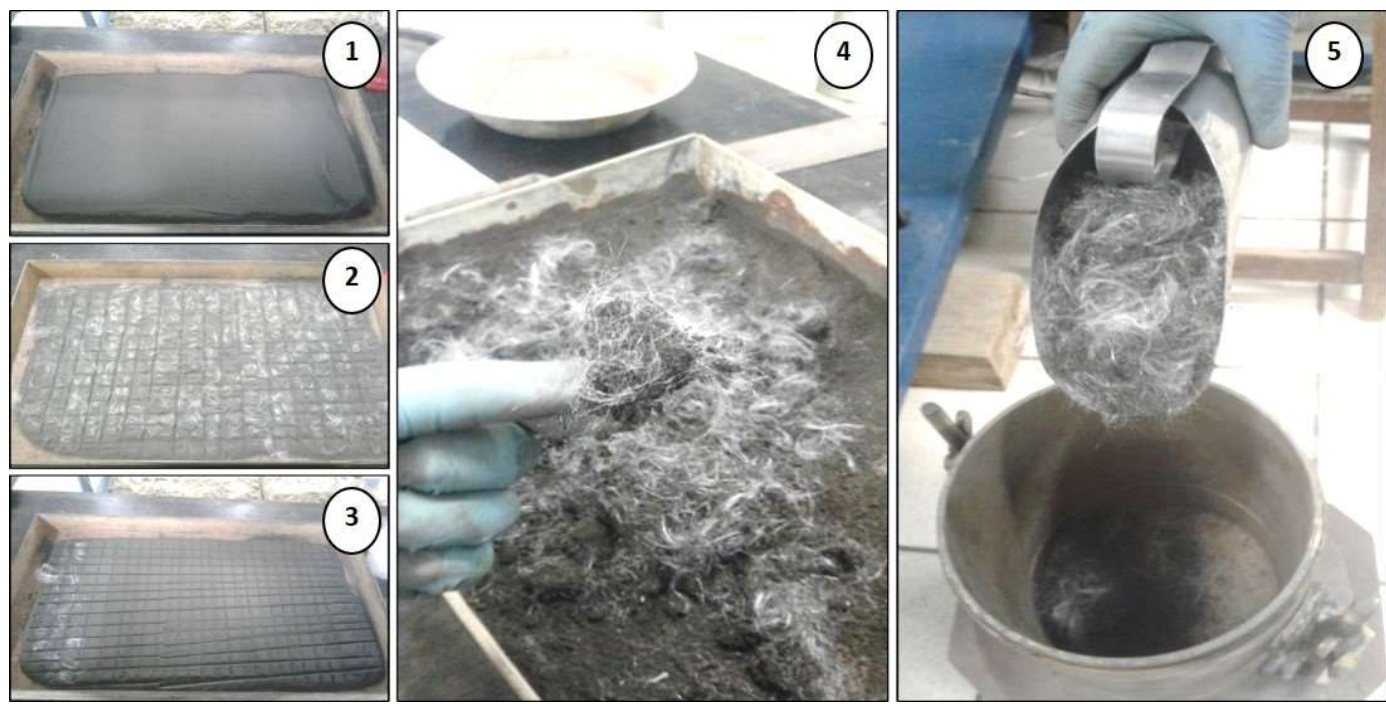

1. Colocação da camada base de rejeito de minério de ouro.

2. Desfiado das fibras de polipropileno sobre a camada base.

3. Colocação da segunda camada de rejeito de minério de ouro.

4. Mistura dos materiais até conseguir homogeneidade visual na distribuição das fibras.

5. Colocação da mistura no molde Proctor.

Figura 3.8. Processo de mistura rejeito de minério - fibra

Após a compactação, a amostra foi retirada do molde, e fracionada em três blocos, cada bloco foi colocado sobre um torno manual, com base giratória, sendo talhado cuidadosamente, com auxílio de uma faca afiada ou uma régua desbastando lateralmente a superfície até conseguir o diâmetro uniforme em toda a altura do bloco. No caso dos blocos reforçados o cuidado foi maior pois durante o desbaste, 
as fibras ancoradas na matriz podem arrancar o material que se encontra dentro do cilindro ao serem puxadas. A Figura 3.9 mostra o processo de moldagem dos corpos de prova de rejeito de minério de ouro.

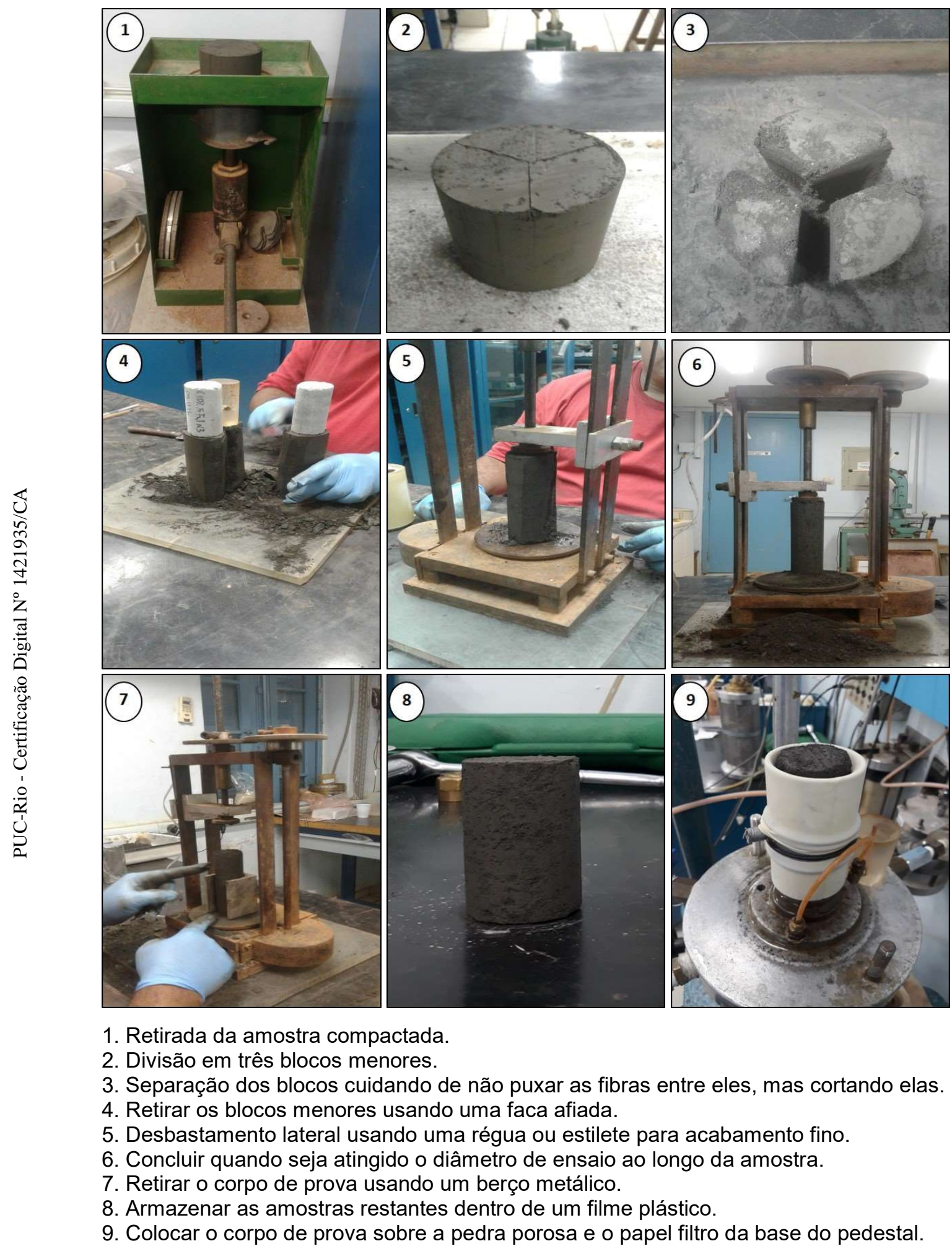

Figura 3.9. Sequência da montagem do corpo de prova Rejeito de minério de ouro 
Depois de tomar as dimensões, peso e uma amostra para o ensaio de umidade do corpo de prova, a amostra foi colocada no pedestal da câmara triaxial, sobre o papel filtro que protege a pedra porosa saturada da base.

Com auxílio de um molde bipartido foi possível colocar a membrana e os $O$ rings no corpo de prova. Finalmente colocou-se o papel filtro, a pedra porosa e o top-cap colocando a membrana sobre eles e vedando o conjunto com os o-rings.

\section{Fase de Saturação por Percolação e Contrapressão}

Para ambas as amostras realizou-se saturação por percolação e posteriormente aplicação de incrementos de pressão confinante e contrapressão.

A percolação foi feita primeiro com a finalidade de preencher os vazios da amostra com água e assim expulsar o ar existente entre partículas. O fluxo de água foi realizado da base para o topo do corpo de prova mantendo uma diferença de pressão de $5 \mathrm{kPa}$ para evitar modificar a estrutura do rejeito durante a passagem da água.

Para evitar fluxo entre a membrana de látex e o corpo de prova foi aplicada uma pressão confinante de $10 \mathrm{kPa}$. Para assegurar a saturação das linhas, pela continua saída de bolhas de ar, em intervalos regulares fechavam-se as válvulas de entrada/saída ao corpo de prova e circulava-se água desde a linha de água do reservatório.

Esta fase de saturação acabou quando a medida do parâmetro $B\left(B=\Delta u / \Delta \sigma_{c}\right)$ não mudava entre dois medições sucessivas. A contrapressão é a fase sucessiva de procura da saturação definitiva do corpo de prova mediante a dissolução do ar na água.

Realizou-se com incrementos sucessivos de pressão confinante e contrapressão mantendo uma diferença de pressão entre eles de $5 \mathrm{kPa}$, sendo inicialmente os acréscimos de $25 \mathrm{kPa}$ até um valor de parâmetro $\mathrm{B}$ de $0,70 \mathrm{e}$ subsequentes acréscimos de $50 \mathrm{kPa}$. O critério para passar ao seguinte incremento de pressão foi a estabilização do MVV.

O controle da saturação foi feito ao final de cada estágio mediante a leitura do parâmetro $\mathrm{B}$, considerando a saturação total para $\mathrm{B} \geq 0,98$. A saturação foi alcançada de forma geral em ambos os rejeitos de minério em tensões confinantes de $400 \mathrm{kPa}$. 


\section{Fase de Adensamento Isotrópico}

Após a saturação, realizou-se o adensamento isotrópico segundo a tensão efetiva de confinamento previamente estabelecida. A pressão de confinamento padrão máxima foi de $700 \mathrm{kPa}$ para todos os ensaios, portanto a contrapressão foi a subtração desse valor fixo menos a tensão efetiva de confinamento.

Uma vez alcançada a contrapressão base as válvulas de base e topo foram fechadas e se incrementou a pressão de confinamento em condições não drenadas até $700 \mathrm{kPa}$, as leituras do transdutor de deslocamento e MVV foram anotadas e as válvulas de base e topo foram abertas começando o adensamento isotrópico que finalizava com a estabilização da variação volumétrica. Após o adensamento, realizou-se a atualização dos novos índices físicos pelas variações de altura e volume do corpo de prova.

\section{Fase de Cisalhamento triaxial}

$\mathrm{Na}$ fase de cisalhamento dependendo do ensaio ser drenado ou não drenado, as válvulas do corpo de prova eram abertas ou fechadas, respectivamente. Em ambos os casos a compressão axial de $0,032 \mathrm{~mm} / \mathrm{min}$ foi o suficientemente lenta para, no caso drenado, permitir a total drenagem da água do corpo de prova, e no caso não drenado, permitir a equalização dos excessos de poropressão gerados ao longo do corpo de prova. O cisalhamento direto, por limitações do equipamento, foi realizado até alcançar o $20 \%$ da deformação axial. Ao final do ensaio, determinou-se o teor de umidade para cada corpo de prova.

\subsection{2.}

\section{Ensaios de cisalhamento direto com plano cisalhado}

Este ensaio teve por finalidade obter uma resposta dos rejeitos de mineração não reforçados e reforçados na condição residual. Nesse sentido, realizou-se o ensaio de cisalhamento direto convencional com tensões normais verticais de 25 , $50,100,200$ e 400 kPa na condição inundada. Os parâmetros de resistência obtidos foram comparados com os resultados dos ensaios triaxiais para ver o nível de variação entre eles. Após o ensaio convencional, o corpo de prova cisalhado era retirado da caixa de ensaios e com um fio fino de aço realizou-se um corte ao longo da superfície de ruptura separando ambas as caixas superior e inferior. O rejeito 
dentro de ambas as caixas foi polido na superfície, e posteriormente, as caixas foram colocadas novamente em contato para dar início ao ensaio residual.

\subsubsection{1.}

\section{Equipamento, instrumentação, aquisição de dados, acessórios}

Nos ensaios de cisalhamento direto foram utilizadas duas prensas do tipo Wykeham -Farrance, modelo 25210, que funcionam mediante um motor elétrico associado a um jogo de engrenagens responsáveis de impor as velocidades de deslocamento. As cargas verticais são aplicadas mediante um sistema de carga pendural com braço de alavanca. O sistema de aquisição de dados utilizado foi descrito no item 3.3.1.1.5, as medições de força horizontal e deslocamento vertical e horizontal foram feitas por anéis de carga instrumentados desenvolvidos na PUCRio e transdutores de deslocamento LSCDT, respectivamente.

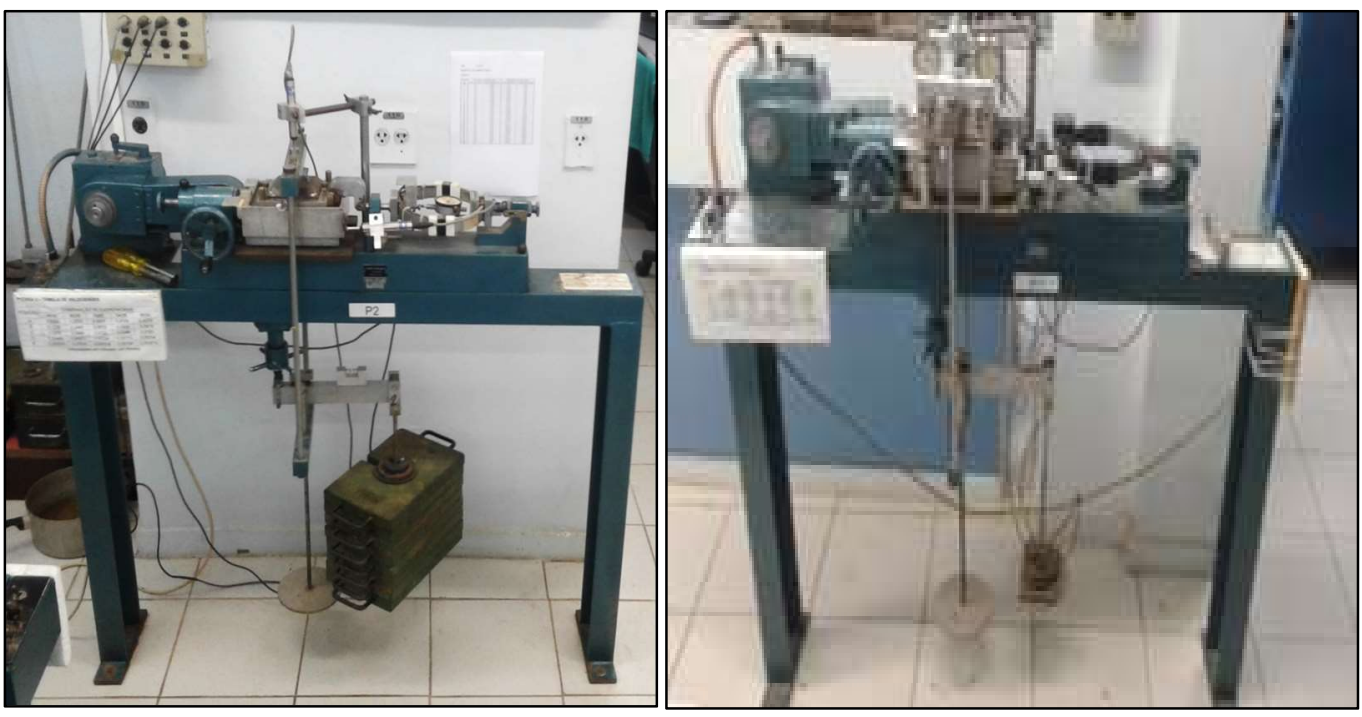

Figura 3.10. Equipamentos de cisalhamento direto

\subsubsection{2.}

\section{Metodologia empregada}

\section{Moldagem dos corpos de prova}

Para a moldagem dos corpos de prova utilizou-se um molde metálico de seção quadrada de $10 \mathrm{~cm}$ de lado e $2 \mathrm{~cm}$ de altura, embora, o processo de moldagem foi diferente para cada tipo de rejeito de mineração.

Para o rejeito de minério de ferro, a moldagem foi feita diretamente no molde metálico, mostrado na Figura 3.11, seguindo o mesmo processo realizado nos 
ensaios triaxiais onde a quantidade de materiais foi calculada por camada segundo o volume do molde, a mistura e compactação foram iguais para amostras não reforçadas e reforçadas.
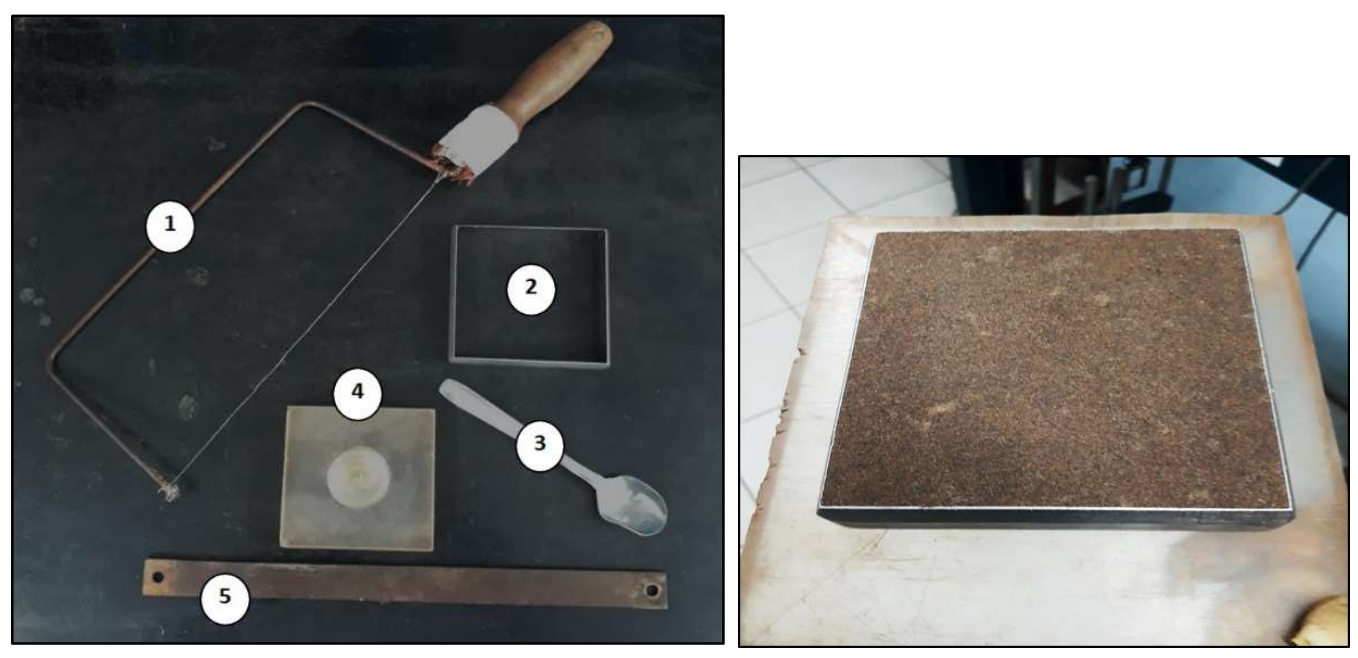

1. Fio de aço

2. Molde metálico

3. Colher de aço

4. Compactador manual

5. Régua metálica

Figura 3.11. Ferramentas e moldagem do rejeito de minério de ferro

No caso do rejeito de minério de ouro, realizou-se a compactação no molde de Proctor da forma descrita nos ensaios triaxiais, e colocou-se o molde metálico para talhar, com auxílio de uma faca afiada, o corpo de prova, o extremo biselado do molde, como mostra a Figura 3.12, foi colocado em contato com o rejeito compactado favorecendo o corte. A Figura 3.12 mostra a moldagem final do rejeito de minério de ouro.
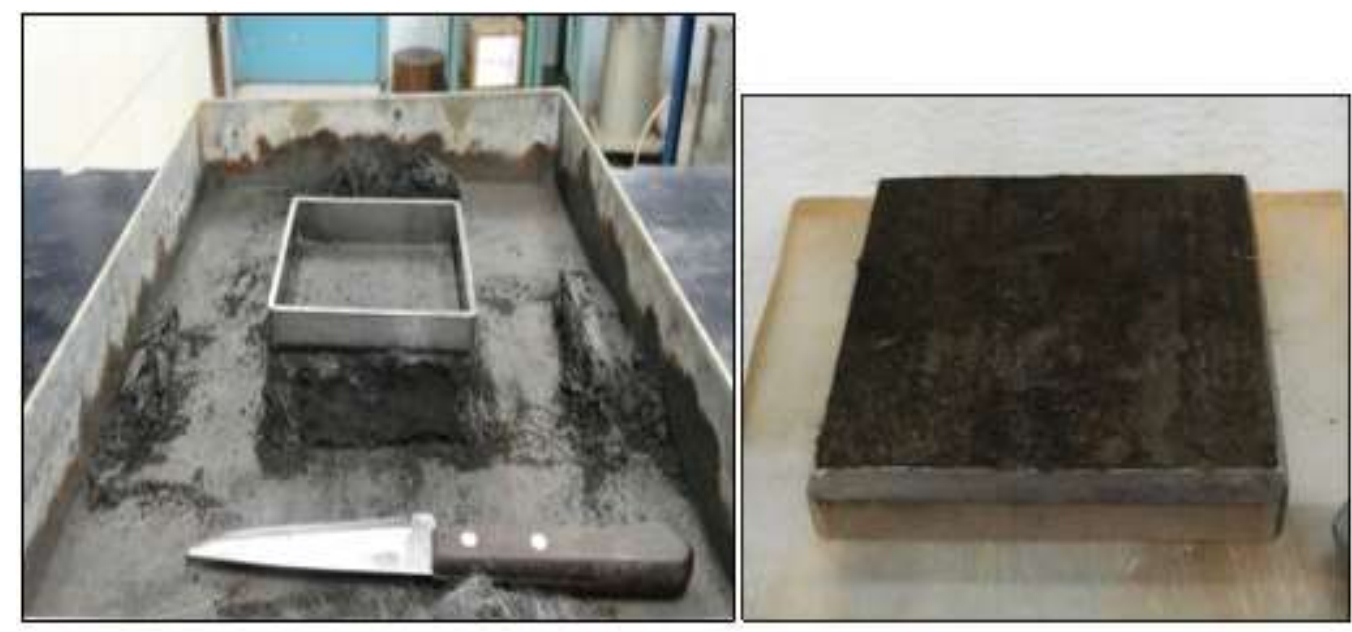

Figura 3.12. Ferramentas e moldagem do rejeito de minério de ouro 


\section{Montagem do ensaio}

Após a moldagem dos corpos de prova, a montagem no equipamento de cisalhamento direto foi igual para ambos os rejeitos de minério como se mostra na Figura 3.13 .

Colocou-se a caixa de cisalhamento parafusada dentro do carro suporte do equipamento, dentro desta caixa foram colocados uma placa de aço de base furada para permitir a drenagem de entrada e saída de água do corpo de prova e uma pedra porosa saturada com o papel filtro protetor, para impedir a contaminação da pedra porosa. Posteriormente outra malha de aço furada e com canais transversais ao sentido do deslocamento foi colocada para drenagem e fixação da base do corpo de prova e depois com ajuda de um compactador manual procedeu-se à colocação da amostra dentro da caixa.

Finalmente, sobre a amostra colocou-se outra malha de aço furada com canais no topo do corpo de prova, para cumprir com a mesma finalidade mencionada anteriormente e o papel filtro com a pedra porosa saturada. Sobre este conjunto foi colocado um bloco de aço que distribuiu as tensões normais verticais, sobre o qual se colocou o eixo de carregamento e o correspondente transdutor de deslocamento vertical. Durante a montagem verificou-se o nivelamento dos acessórios e da caixa de cisalhamento.

\subsubsection{3.}

\section{Fase de adensamento}

Depois da moldagem do corpo de prova, aplicou-se a carga vertical equivalente à tensao normal vertical no braço de alavanca e inunda-se o interior do suporte da caixa de cisalhamento.

As leituras do adensamento para tensões normais verticais de 25, 50, 100, 200 e $400 \mathrm{kPa}$ foram registradas durante 24 horas quando termina o adensamento sendo isto verificado pela estabilização na leitura do transdutor de deslocamento vertical.

Após o adensamento, retiram-se os parafusos que conetam a caixa inferior e superior de cisalhamento e coloca-se um dispositivo implementado na PUC-Rio, composto por um suporte, quatro parafusos espaçadores e dois extensômetros, para separar a caixa inferior da superior em uma distância de $0,5 \mathrm{~mm}$ com a finalidade de evitar o atrito entre ambas caixas durante o cisalhamento. 

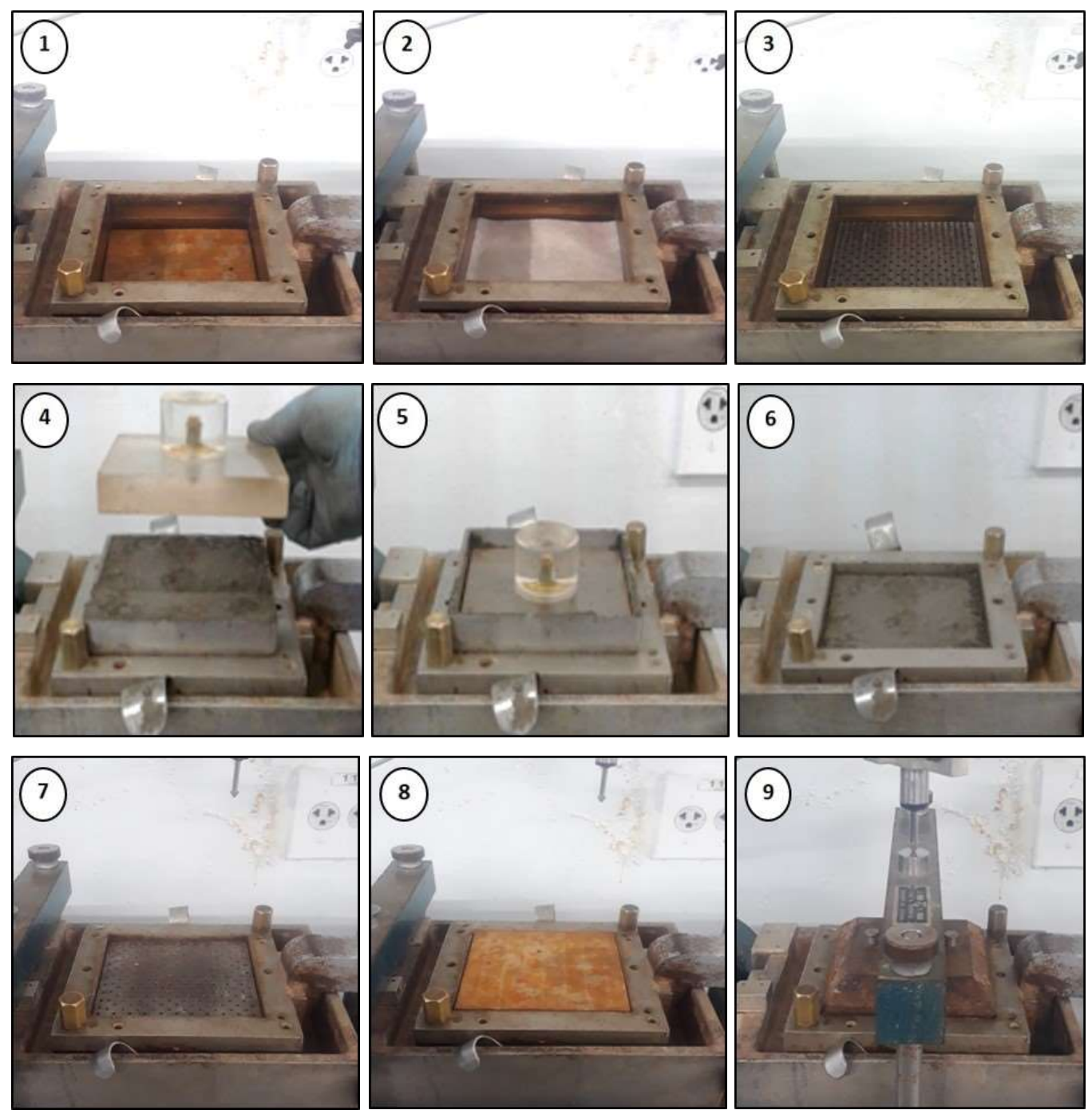

1. Colocação da caixa de ensaios parafusada, base de aço e pedra porosa saturada.

2. Colocação de papel filtro sobre pedra porosa.

3. Colocação de malha de aço furada para fixação da base do corpo de prova e drenagem.

4. Colocação do molde metálico com amostra.

5. Colocação do corpo de prova na caixa de ensaio com auxílio de compactador manual.

6. Corpo de prova em caixa de ensaio.

7. Colocação de malha de aço furada para fixação do topo do corpo de prova e drenagem.

8. Colocação de papel filtro e pedra porosa saturada.

9. Colocação do bloco de aço para distribuição de carga vertical e transdutor de deslocamento vertical.

Figura 3.13. Sequência da montagem do corpo de prova Cisalhamento direto

\subsubsection{4.}

\section{Fase de cisalhamento convencional}

Após a etapa de adensamento calculou-se a velocidade de cisalhamento segundo o critério de Gibson \& Henkel (1954) sendo adotada uma velocidade constante de $0,06 \mathrm{~mm} / \mathrm{min}$ que permite garantir a drenagem durante o deslocamento máximo do carro guia da prensa de cisalhamento. O sistema de aquisição de dados 
armazenou os dados dos transdutores de deslocamento, vertical e horizontal, e o anel de carga, o que permite plotar os resultados. Finalizado o ensaio convencional procedeu-se a retirada da água do interior do suporte da caixa de cisalhamento, o alívio da tensão normal vertical e a retirada da caixa de cisalhamento para preparála para a fase de ensaio de plano cisalhado com superfície polida.

\subsubsection{5.}

\section{Fase cisalhamento direto com superfície polida}

Depois do ensaio convencional, para separar as caixas superior e inferior, arrastou-se um fio fino de aço pela superfície cisalhada entre ambas as caixas no sentido do cisalhamento. Com as caixas separadas e com auxílio de um acrílico ligeiramente umedecido e uma régua de aço procedeu-se ao alisamento das superfícies sempre na direção do cisalhamento como mostra a Figura 3.14.

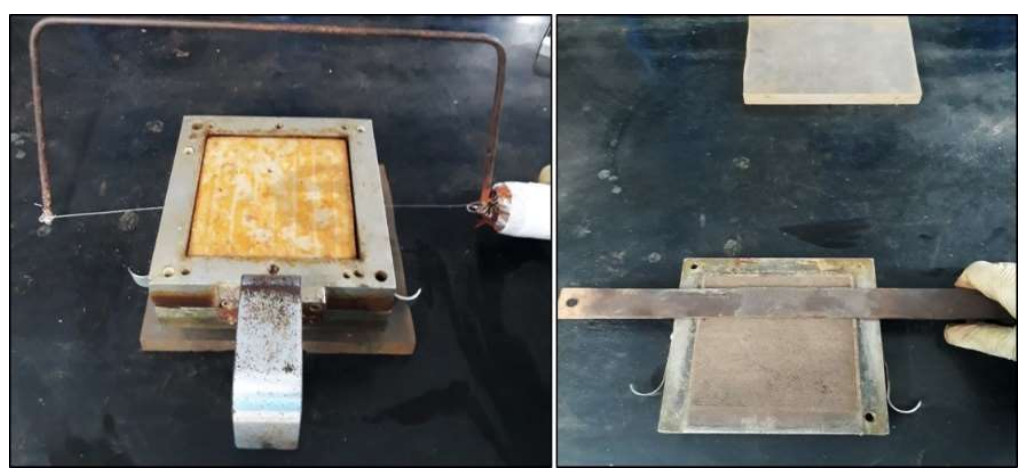

Figura 3.14. Esquema de corte e polimento da superfície cisalhada

Finalmente as caixas foram colocadas em contato e recolocadas no carro guia do equipamento de cisalhamento direto, as tensões normais verticais foram aplicadas e o interior do suporte da caixa novamente inundado. O adensamento de 24 horas foi novamente imposto e o ensaio de cisalhamento direto foi realizado com as mesmas características descritas no item 3.3.2.4.

\section{4}

\section{Considerações Finais}

Os ensaios triaxiais e de cisalhamento direto de plano cisalhado com superfície polida foram realizados com o intuito de determinar a resistência de pico e residual não reforçada e reforçada dos rejeitos de minério de ferro e ouro. 
O método de moldagem dos corpos de prova foi diferente pelas características dos materiais, os corpos de prova do rejeito de minério de ferro foram moldados diretamente nos moldes tripartido e quadrado dos ensaios triaxial e de cisalhamento direto, respectivamente, enquanto os corpos de prova do rejeito de minério de ouro foram talhados após o processo de compactação dinâmico no Proctor normal.

Em ambos os ensaios foi utilizado o mesmo sistema de aquisição de dados, os mesmos acessórios de moldagem e água destilada para o controle da umidade das amostras.

$\mathrm{Na}$ moldagem dos corpos de prova do rejeito de minério de ferro os moldes tripartido e quadrado foram subdivididos em 5 camadas em altura para garantir a densidade do ensaio. Antes e depois de todos os ensaios foi tomada uma medida de umidade. 


\section{4. \\ Caracterização dos rejeitos de minério e fibra de reforço}

A escolha dos minérios de ferro e ouro foi influenciada pela diferente granulometria, composição química e considerável produção de rejeitos no âmbito latino-americano. Brasil e Peru são os dois maiores produtores na América Latina de ferro e ouro, respectivamente. No caso do rejeito de ferro existe na literatura brasileira informações úteis que descrevem o comportamento físico do material pelo grande incentivo que existe no Brasil à pesquisa. No Peru as informações sobre estudos que utilizem rejeitos de minério de ouro são escassas e procedem na maioria das vezes das mineradoras que projetam barragens para contenção de rejeitos, não tendo pesquisas a respeito sobre o reforço deste material com fibras sintéticas, o que estimula a realização deste trabalho.

Por restrições das áreas de segurança e meio ambiente das mineradoras, ambos os rejeitos foram coletados e manipulados por funcionários das companhias e entregues para transporte. Assim mesmo, o sigilo da fonte foi solicitado pelas mineradoras para salvaguardar seus interesses. As amostras foram coletadas de estruturas para armazenamento dos rejeitos, no caso do rejeito de ferro, no eixo central dos diques de alteamento das barragens de contenção, e do rejeito de ouro, no último nível das pilhas de rejeitos filtrados compactados.

\section{1.}

Procedência das matrizes e reforço

$\mathrm{O}$ rejeito de minério de ferro procede dos diques de alteamento, adensados pela passagem dos equipamentos, sobre uma barragem de material de empréstimo. Os rejeitos são transportados por via úmida até as barragens de mineração, onde entram a um processo de ciclagem que separa as partículas grossas (underflow) e finas (overflow), sendo a parte grossa aquela utilizada para o alteamento da barragem.

As amostras deformadas com uma umidade de 14,0\% foram coletadas por funcionários da mineradora em diferentes posições distanciadas 50 metros do eixo 
central do último dique de alteamento, para saber se existe muita heterogeneidade entre amostras, utilizando ferramentas manuais. As amostras foram colocadas em filme alumínio dentro de sacolas plásticas identificadas e lacradas, para depois serem colocadas em caixas e entregues para transporte. Não foram fornecidas amostras indeformadas.

O rejeito de minério de ouro procede de um depósito de rejeitos filtrados e compactados em aterros que em conjunto têm uma altura de $30 \mathrm{~m}$. Os rejeitos são transportados em caminhões até o ponto de colocação final, onde são compactados com rolo de 10 t. As amostras deformadas com uma umidade de 14,5\% foram coletadas em sacolas plásticas de $10 \mathrm{~kg}$ por funcionários da mineradora e entregues para transporte. Não foram fornecidas amostras indeformadas.

As fibras de polipropileno foram obtidas pela parceria feita com Maccaferri, uma empresa fabricante. O produto de uso comercial é na maioria das vezes indicado para reforço de concretos e argamassas com boa trabalhabilidade para gerar compósitos homogêneos.

\section{2. \\ Caracterização dos Rejeitos de Mineração}

As propriedades físicas e mecânicas dos rejeitos de mineração dependem do tipo de minério, do processo de produção do minério, do tipo de deposição, local e idade da jazida, portanto as características são bastante variáveis sendo necessário caracterizar as propriedades físicas, químicas e mineralógicas dos resíduos (Bedin, 2008). Portanto, ao se caracterizar fisicamente um rejeito, deve-se ter sempre em consideração que é resultante de uma sucessão de processos físicos e químicos, e que não há necessariamente uma correlação entre a distribuição de tamanhos das partículas sólidas e a sua composição mineralógica, como ocorre nos solos naturais (Barbosa et al., 2003).

Ensaios de caracterização física foram realizados para obter propriedades índice como peso específico natural $\left(\gamma_{n a t}\right)$, peso específico seco $\left(\gamma_{d}\right)$, índice de vazios (e), grau de saturação (S) e densidade real dos grãos. Tal caracterização foi feita no Laboratório de Geotecnia e Meio Ambiente da PUC-Rio, utilizando amostras amolgadas. As amostras foram preparadas de acordo com o procedimento de secagem prévia, conforme a NBR 6457 (ABNT, 1986-a), seguindo as demais recomendações da Associação Brasileira de Normas Técnicas (ABNT). 


\subsection{1.}

\section{Análise Granulométrica}

Os rejeitos de minério são materiais submetidos a forte desgaste físicoquímico, portanto existe muito material passante da peneira \#200, em tal sentido, para definir a granulometria realizaram-se três ensaios de granulometria por peneiramento e sedimentação conforme à NBR 7181 (ABNT, 1984-a) e três ensaios utilizando um granulómetro a laser para comparar as curvas na fração fina para cada tipo de rejeito, pela variabilidade que pode existir entre as amostragens. Ambas as metodologias utilizaram como agente defloculante uma solução de hexametafosfato de sódio.

\subsubsection{1.}

\section{Rejeito de Minério de Ferro}

No Rejeito de Minério de Ferro, os resultados das análises granulométricas por ambos os métodos determinaram pouca variabilidade entre as amostras das diferentes caixas.

$\mathrm{Na}$ Tabela 4.1, apresentam-se as porcentagens obtidas segundo os diâmetros de partícula para cada amostra analisada. Na Figura 4.1 mostram-se as curvas granulométricas superpostas das amostras com defloculante e sem defloculante, nota-se que não existe considerável variação da fração fina. Os principais índices físicos de uma curva granulométrica representativa do rejeito de minério de ferro são mostrados na Tabela 4.2. Na Figura 4.2 são apresentados os ensaios de sedimentação.

Tabela 4.1. Análises Granulométrica do Rejeito de Minério de Ferro

\begin{tabular}{|c|c|c|c|c|c|c|c|c|}
\hline \multirow{2}{*}{ Amostra } & \multirow{2}{*}{ Argila } & \multirow{2}{*}{ Silte } & \multicolumn{3}{|c|}{ Areia } & \multicolumn{3}{|c|}{ Pedregulho } \\
\hline & & & Fina & Meia & Grossa & Fino & Meio & Grosso \\
\hline S-Fe-01-D & 0,69 & 13,98 & 67,97 & 17,04 & 0,32 & 0,00 & 0,00 & 0,00 \\
\hline S-Fe-02-D & 1,70 & 16,03 & 70,56 & 11,56 & 0,15 & 0,00 & 0,00 & 0,00 \\
\hline S-Fe-03 & 0,84 & 15,81 & 75,30 & 7,91 & 0,15 & 0,00 & 0,00 & 0,00 \\
\hline L-Fe-01-D & 0,00 & 16,95 & 79,73 & 3,32 & 0,00 & 0,00 & 0,00 & 0,00 \\
\hline L-Fe-02-D & 0,00 & 13,57 & 78,15 & 8,28 & 0,00 & 0,00 & 0,00 & 0,00 \\
\hline L-Fe-03 & 0,00 & 13,56 & 77,41 & 9,03 & 0,00 & 0,00 & 0,00 & 0,00 \\
\hline Desvio Padrão & 0,68 & 1,46 & 4,63 & 4,55 & 0,13 & 0,00 & 0,00 & 0,00 \\
\hline S: Sedimentação & L: Gran & ómetro & aser & Fe: Rejei & de Minér & de Ferr & $\mathrm{D}: \mathrm{De}$ & loculante \\
\hline
\end{tabular}


Tabela 4.2. Índices físicos do Rejeito de minério de ferro

\begin{tabular}{lc}
\hline Diâmetro efetivo $\mathrm{D}_{10}$ & 0,0490 \\
\hline Diâmetro médio $\mathrm{D}_{50}$ & 0,1000 \\
\hline Coeficiente de uniformidade $(\mathrm{Cu})$ & 1,5 \\
\hline Coeficiente de curvatura $(\mathrm{Cc})$ & 0,9 \\
\hline
\end{tabular}

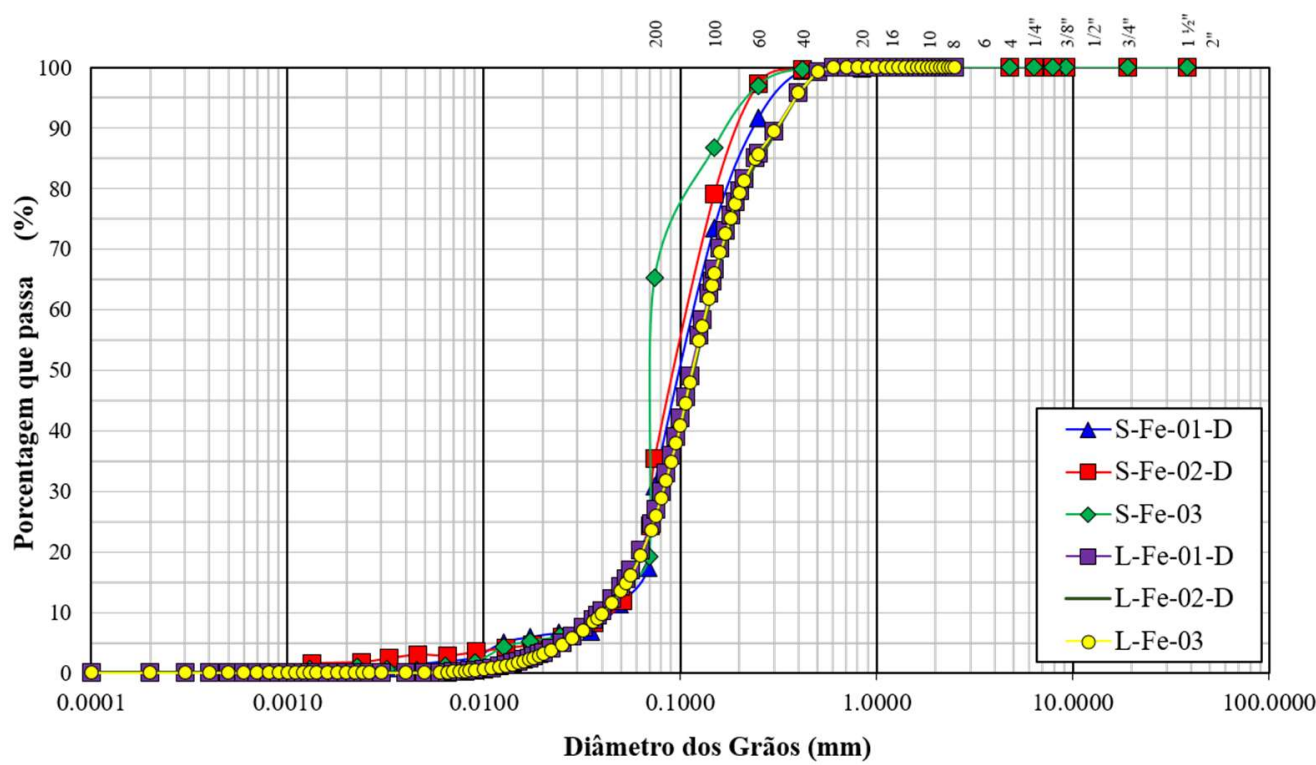

Figura 4.1. Curvas granulométricas no Rejeito de minério de ferro amostras com defloculante e sem defloculante
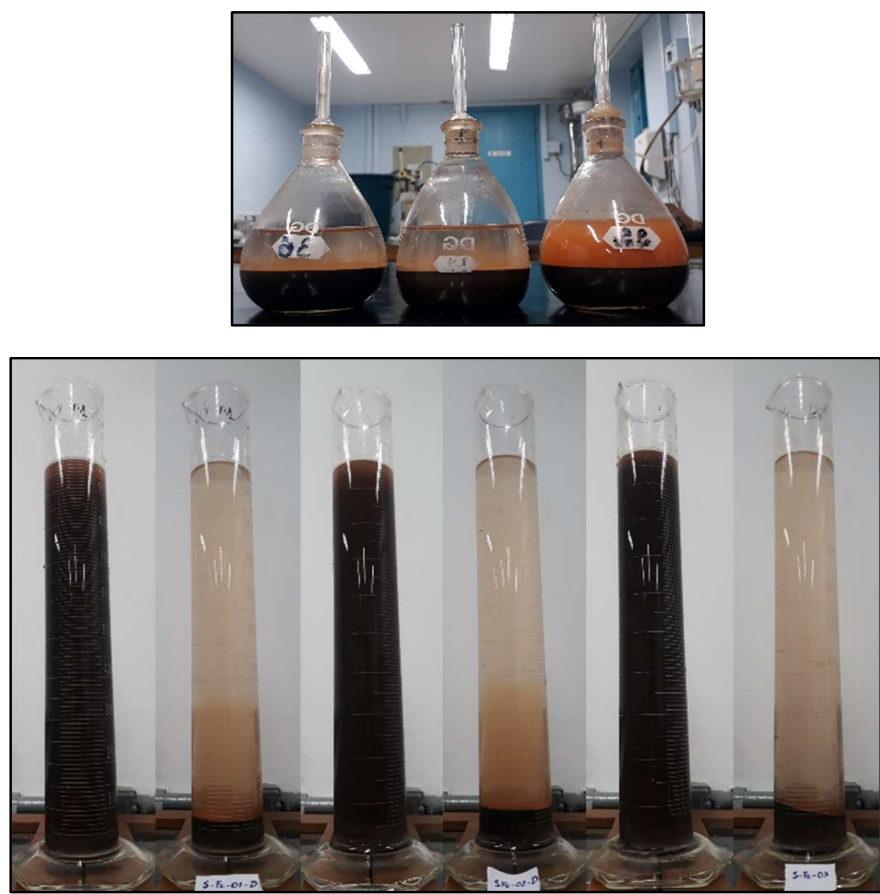

(a)

(a)

(b)

Figura 4.2. Ensaios de sedimentação no Rejeito de minério de ferro

(a) hexametafosfato de sódio e (b) água 


\subsubsection{2.}

\section{Rejeito de Minério de Ouro}

As amostras de Rejeito de Minério de Ouro apresentaram torrões com diâmetros desde areias até pedregulhos médios com um teor de umidade de 14\%. A análise granulométrica, após o processo de destorroamento, encontrou uma porcentagem maior do que $95 \%$ passante na peneira \#200. Pelo fato de se encontrar torrões, a aplicação do defloculante foi feita em todos os casos seguindo recomendação da norma NBR 7181 (ABNT, 1984-a) que adverte a necessidade do uso de um agente químico dispersor para separar as agregações de partículas. Comparando os métodos de sedimentação e do granulómetro a laser verifica-se que existem partículas do tamanho argila mas com uma considerável diferença nas porcentagens, uma maior porcentagem de argila se consegue no método de sedimentação.

Tabela 4.3. Análises Granulométrico do Rejeito de Minério de Ouro

\begin{tabular}{|c|c|c|c|c|c|c|c|c|}
\hline \multirow{2}{*}{ Amostra } & \multirow{2}{*}{ Argila } & \multirow{2}{*}{ Silte } & \multicolumn{3}{|c|}{ Areia } & \multicolumn{3}{|c|}{ Pedregulho } \\
\hline & & & Fina & Meia & Grossa & Fino & Meio & Grosso \\
\hline S-Au-01-D & 25,24 & 72,89 & 1,87 & 0,00 & 0,00 & 0,00 & 0,00 & 0,00 \\
\hline S-Au-02-D & 26,52 & 71,61 & 1,87 & $\mathbf{0 , 0 0}$ & $\mathbf{0 , 0 0}$ & $\mathbf{0 , 0 0}$ & $\mathbf{0 , 0 0}$ & $\mathbf{0 , 0 0}$ \\
\hline S-Au-03-D & 23,12 & 76,82 & 0,06 & 0,00 & 0,00 & 0,00 & 0,00 & 0,00 \\
\hline L-Au-01-D & 6,26 & 93,35 & 0,39 & 0,00 & 0,00 & 0,00 & 0,00 & 0,00 \\
\hline L-Au-02-D & 6,16 & 93,23 & 0,61 & 0,00 & 0,00 & 0,00 & 0,00 & 0,00 \\
\hline L-Au-03-D & 5,88 & 93,33 & 0,79 & 0,00 & 0,00 & 0,00 & 0,00 & 0,00 \\
\hline Desvio Padrão & 10,39 & 10,83 & 0,77 & 0,00 & 0,00 & 0,00 & 0,00 & 0,00 \\
\hline
\end{tabular}

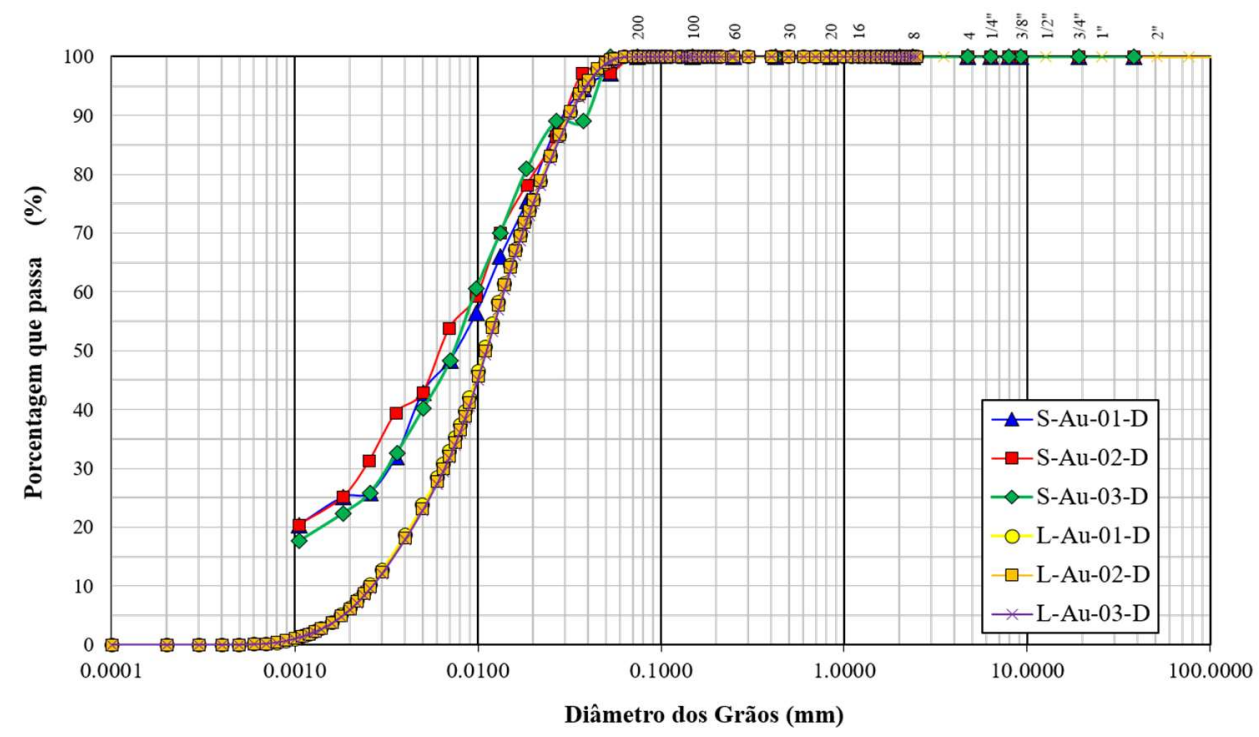

Figura 4.3. Curvas granulométricas no Rejeito de minério de ouro Amostras com defloculante 

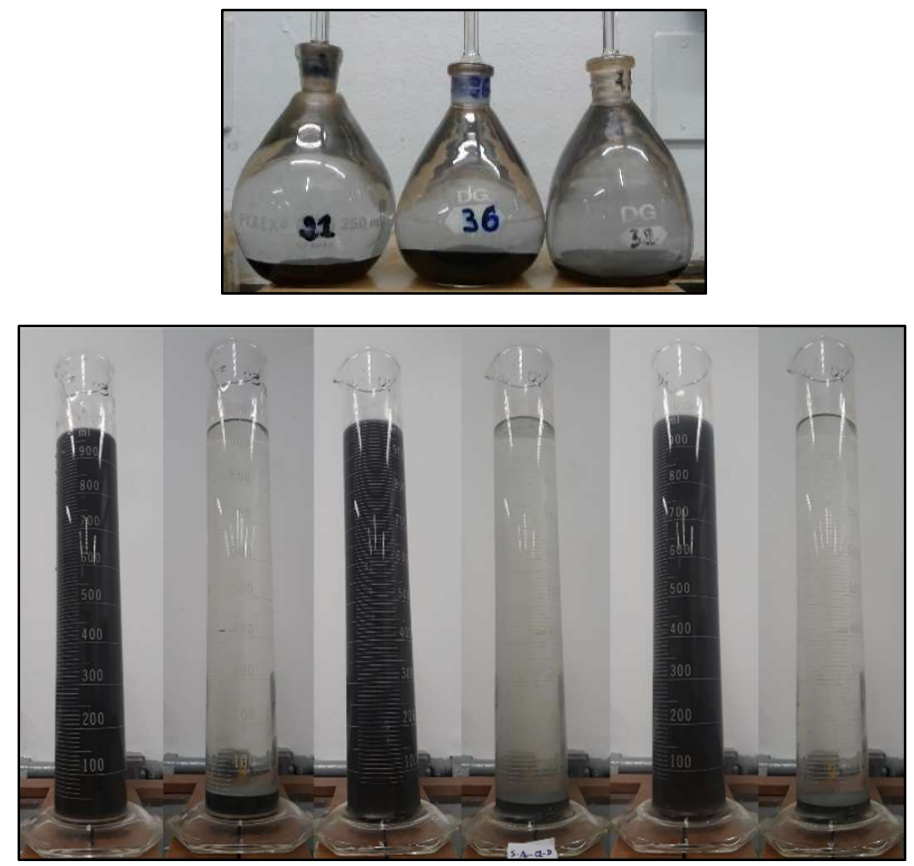

Figura 4.4. Ensaios de sedimentação no Rejeito de minério de ouro com hexametafosfato de sódio

Ribeiro et al., (2014) analisou ambos os métodos em um solo argiloso usando os resultados da sedimentação tradicional obtidos por Angelim (2011) e os resultados obtidos mediante uso de granulómetro a laser. Reportou que o uso de defloculante hexametafosfato de sódio conjugado ao uso do ultrassom do granulómetro laser acusou um material de gradação maior que a real, atribuindo a ocorrência ao possível surgimento de bolhas/espuma no meio dispersor que provoca uma alteração na transparência deste.

Comparou também os resultados no granulómetro a laser utilizando somente hexametafosfato ou ultrassom, encontrando uma maior coerência nos resultados do ultrassom. Não obstante, indicou que o método por sedimentação é mais confiável porque o ultrassom é um processo mecânico e atua bem para partículas maiores, mas o defloculante, por ser um processo químico, é mais eficiente principalmente no que tange às partículas menores cujas agregações ou adesão às outras estão governadas por forças de natureza elétrica ou eletrônica.

Tabela 4.4. Índices físicos do rejeito de minério de ouro

\begin{tabular}{lc}
\hline Diâmetro efetivo $\mathrm{D}_{10}$ & 0,0008 \\
\hline Diâmetro médio $\mathrm{D}_{50}$ & 0,0076 \\
\hline Coeficiente de uniformidade $(\mathrm{Cu})$ & - \\
\hline Coeficiente de curvatura $(\mathrm{Cc})$ & - \\
\hline
\end{tabular}


Os resultados mostrados na Tabela 4.3 coincidem com a apreciação de Ribeiro et al. (2014), portanto, no caso do rejeito de minério de ouro a granulometria está definida pela sedimentação e os índices físicos mostrados na Tabela 4.4 correspondem a uma curva representativa usando somente esse método. $\mathrm{O}$ rejeito de minério de ouro é classificado pelo Sistema Único de Classificação de Solos (SUCS) como uma argila siltosa de baixa plasticidade (CL-ML).

\subsection{2.}

\section{Limites de Atterberg}

Realizaram-se ensaios de limite de liquidez e plasticidade segundo as normas NBR 6459 (ABNT, 1984-b) e a NBR 7180 (ABNT, 1984-c), respectivamente, utilizando o material com secagem prévia ao meio ambiente, destorroado e passante da peneira de $0,42 \mathrm{~mm}$ de abertura. $O$ rejeito de minério de ferro não apresentou plasticidade e os limites do rejeito de ouro são apresentados na Tabela 4.5. O índice de plasticidade é obtido por IP=LL-LP.

Tabela 4.5. Limites de Atterberg Índices de consistência

\begin{tabular}{lccc}
\hline Rejeito & $\begin{array}{c}\text { LL-W } \\
(\mathbf{\%})\end{array}$ & $\begin{array}{c}\text { LP-W } \\
\mathbf{( \% )}\end{array}$ & $\begin{array}{c}\text { IP } \\
\mathbf{( \% )}\end{array}$ \\
\hline Minério de Ferro & \multicolumn{2}{c}{ Não Apresenta Plasticidade } \\
\hline Minério de Ouro & 19 & 13 & 6 \\
\hline
\end{tabular}

Com o índice de plasticidade é possível determinar o nível de atividade da argila. Os limites de Atterberg indicam a influência dos finos argilosos no comportamento do solo. Alguns solos com alto teor de argila podem apresentar limites mais baixos comparados com outros com menor teor de argila, isto porque a composição mineralógica pode ser muito variável. Um baixo teor de argila mas com um alto índice de consistência indica que a argila é muito ativa. De acordo com Skempton, o índice de atividade (Ia), correspondente à fração argila, é calculado pela equação 4.1 .

$I_{a}=\frac{I P}{\%<2 \mu m}$

A classificação segundo a atividade é: inativa $\left(I_{a}<0,75\right)$, atividade normal $\left(0,75<I_{a}<1,25\right)$ e ativa $\left(I_{a}>1,25\right)$, classificando o rejeito de minério de ouro com $I_{a}=0,22$, como inativa. 


\subsection{3.}

\section{Massa específica dos rejeitos $\left(\rho_{s}\right)$}

A massa específica dos rejeitos é função da massa especifica dos grãos que os constituem, portanto, para rejeitos de mineração que em geral é a $\rho$ s maior do que para a maioria dos solos naturais, porque nos rejeitos há uma concentração de óxidos, cuja massa específica é mais alta do que a dos minerais dominantes nos solos naturais, como o quartzo e a caulinita.

As partículas de ferro, por si só, apresentam massa específica dos grãos em torno de $5,25 \mathrm{~g} / \mathrm{cm}^{3}$, enquanto os grãos de quartzo são caracterizados por possuírem uma massa específica em torno de $2,65 \mathrm{~g} / \mathrm{cm}^{3}$. Portanto, os rejeitos de minério de ferro, que são compostos basicamente de partículas de quartzo, hematita e outros minerais, tendem a apresentar uma faixa de variação da densidade dos grãos entre estes dois extremos (Pereira, 2005).

O ensaio para determinação da massa especifica ( $\rho s)$ e densidade relativa dos grãos (Gs) foi executado de acordo com o mesmo procedimento prescrito para solos naturais, de acordo com as normas NBR 6508 (ABNT, 1984-d) e ME 093 (DNER, 1994).

A densidade relativa dos grãos (Gs) dos rejeitos de minério de ferro e ouro são 2,89 e 3,77, respectivamente.

Na Figura 4.5 apresentam-se alguns resultados de densidade dos grãos em rejeitos de ferro e ouro, existentes na literatura, incluindo os resultados obtidos nesta pesquisa, mostrando coerência nos resultados.

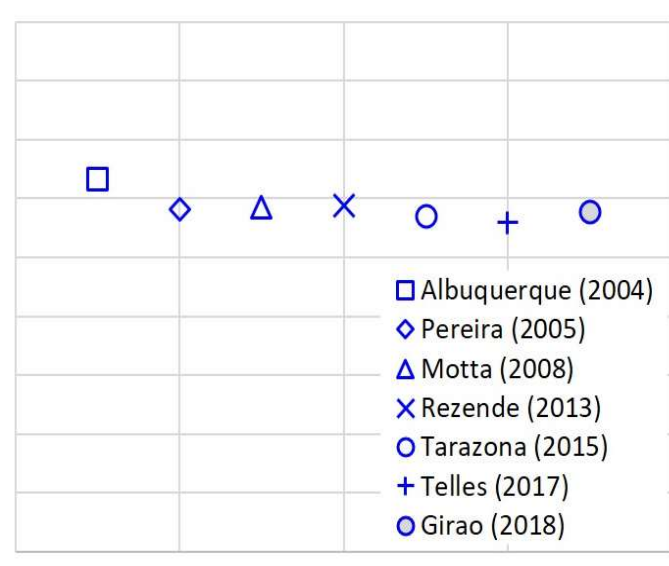

Rejeito de Minério de Ferro

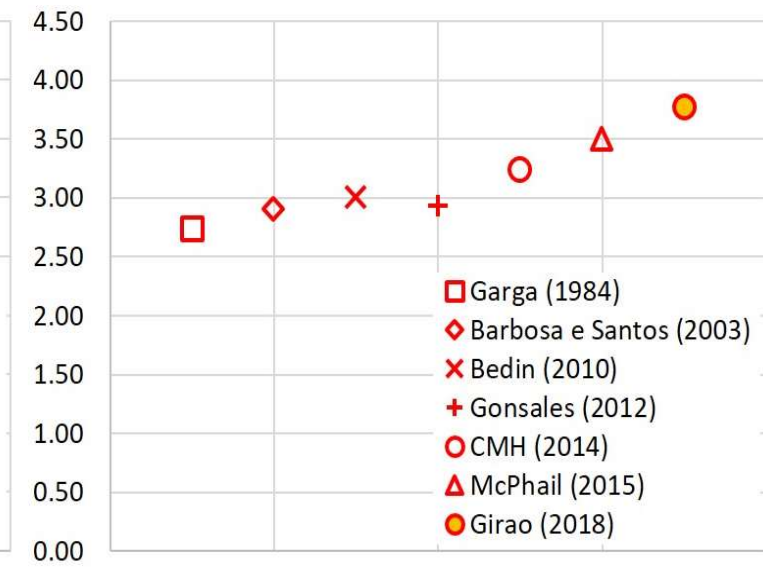

Rejeito de Minério de Ouro

Figura 4.5. Densidade relativa dos grãos de rejeito $(\mathrm{Gs})$ 


\subsection{4.}

\section{Potencial hidrogeniônico (pH)}

O potencial hidrogeniônico $(\mathrm{pH})$ é a medida do teor de íons $\mathrm{H}_{3} \mathrm{O}^{+}$livres por unidade de volume do rejeito em suspensão tanto em água destilada quanto em uma solução saturada de $\mathrm{KCl}$, quanto maior for esse teor, mais ácido é considerado o rejeito, assim um pH ácido apresenta valores entre 1,0 e 6,0; 7 é neutro e de 8 a 14 é básico ou alcalino. O ensaio foi realizado no Laboratório de Geotecnia e Meio Ambiente da PUC-Rio seguindo as recomendações do Manual de Métodos de Análises de Solos (EMBRAPA, 1997).

Medições foram feitas utilizando um pHmetro previamente calibrado com duas soluções de $\mathrm{pH}$ conhecido de 4 e 7 . O ensaio consiste em misturar o rejeito com uma solução de $\mathrm{H}_{2} \mathrm{O}$ ou de $\mathrm{KCl}$ em uma proporção de 1:2,5 deixando em repouso uma hora, após o qual se mistura novamente a solução com um bastão de vidro e se introduz o eletrodo do pHmetro na solução, para realizar a leitura de $\mathrm{pH}$.

$\mathrm{Na}$ Tabela 4.6 apresentam-se os resultados do ensaio para cada tipo de rejeito de minério. Através do $\Delta \mathrm{pH}$ pode-se determinar se o rejeito possui capacidade de retenção de cátions ou ânions (Agnelli \& Albiero, 1997), sendo que, valores positivos indicam retenção de ânions e valores negativos retenção de cátions.

Tabela 4.6. Grau de acidez

\begin{tabular}{lccc}
\hline Rejeito de Minério & \multicolumn{2}{c}{ Ferro } & Ouro \\
\hline Método & $\mathrm{H} 20$ & $\mathrm{KCl}$ & $\mathrm{H} 20$ \\
\hline $\mathrm{pH}-01$ & 8,85 & 8,44 & 5,50 \\
$\mathrm{pH}-02$ & 8,84 & 8,76 & 5,80 \\
pH-03 & 8,83 & 8,64 & 5,80 \\
\hline Desvio Padrão & 0,01 & 0,16 & 0,17 \\
Média & 8,84 & 8,61 & 5,70 \\
\hline$\Delta \mathbf{p H}$ & $\mathbf{- 0 , 2 3}$ & \\
$\Delta \mathrm{ph}: \mathrm{ph} \mathrm{KCl}-\mathrm{pH}_{2} 0$ & \multicolumn{3}{|}{}
\end{tabular}

No caso do $\mathrm{pH}$ do rejeito de ferro apresenta possibilidade de retenção de cátions sendo alcalino $(8,84)$, enquanto o rejeito de ouro apresenta $\mathrm{pH}$ ácido $(5,70)$, por conseguinte, as fibras utilizadas para reforço dos rejeitos de mineração devem apresentar resistência ao ataque álcali e ácido.

De todas as fibras sintéticas, as fibras de polipropileno se mostram adequadas para este propósito. As características das fibras são apresentadas no item 4.3. 


\subsection{5.}

\section{Análise de Fluorescência}

A fim de determinar a mineralogia do rejeito se realizou a análise de fluorescência (XRF) que utiliza sinais de raios-X. Os elementos individuais presentes na amostra emitem seus raios-X característicos (fluorescentes) e o espectrômetro (EDS) detecta estes raios-X e, qualitativamente, determina quais elementos estão presentes no material.

Para isto, as amostras passantes na peneira $n^{\circ} 200$ foram fundidas em tetraborato de lítio e analisadas no laboratório de caracterização química da PUCRio.

Na Tabela 4.7 são apresentados os componentes óxidos existentes nos rejeitos de minério de ferro e ouro.

Tabela 4.7. Análise de fluorescência de raios X

\begin{tabular}{ccccccc}
\hline $\begin{array}{c}\text { Rejeito de } \\
\text { minério }\end{array}$ & $\mathrm{SiO}_{2}$ & $\mathrm{Fe}_{2} \mathrm{O}_{3}$ & $\mathrm{Al}_{2} \mathrm{O}_{3}$ & $\mathrm{SO}_{3}$ & $\mathrm{As}_{2} \mathrm{O}_{3}$ & Outros \\
\hline Ferro & 82,67 & 12,91 & 4,35 & 0,00 & 0,00 & 0,07 \\
\hline Ouro & 31,64 & 15,16 & 17,96 & 30,40 & 2,06 & 2,78 \\
\hline
\end{tabular}

No rejeito de minério de ferro, o quartzo $\left(\mathrm{SiO}_{2}\right)$ possui uma maior porcentagem, produto das rochas que apreendem o minério de ferro.

A porcentagem de hematita $\left(\mathrm{Fe}_{2} \mathrm{O}_{3}\right)$ mostra a procedência do rejeito. Existe também um baixo teor de óxido de alumínio $\left(\mathrm{Al}_{2} \mathrm{O}_{3}\right)$ e outros compostos menores.

De igual maneira, no rejeito de minério de ouro, o quartzo possui a maior porcentagem, seguido pelo trióxido de enxofre $\left(\mathrm{SO}_{3}\right)$. O rejeito possui um alto teor de enxofre por minerais como a pirita e arsenopirita. Encontra-se também presença de óxido de alumínio $\left(\mathrm{Al}_{2} \mathrm{O}_{3}\right)$.

Além de não apresentar porcentagem alguma de ouro, a presença de arsenolita $\left(\mathrm{As}_{2} \mathrm{O}_{3}\right)$ pode confirmar a procedência dos rejeitos. A reação química que produz arsenolita é a oxidação da arsenopirita (AsFeS).

Quando a arsenopirita oxida forma óxido de ferro $\left(\mathrm{Fe}_{2} \mathrm{O}_{3}\right)$, arsenolita $\left(\mathrm{As}_{2} \mathrm{O}_{3}\right)$, fumaça de $\mathrm{SO}_{2}$ e o ouro que é retirado. 


\subsection{6.}

\section{Microscopia Eletrônica de Varredura (MEV)}

Realizaram-se ensaios de microscopia eletrônica de varredura (MEV) para a caracterização microscópica dos rejeitos, observação do arranjo dos grãos com a fibra, a possível presença de substâncias cimentantes e a forma e distribuição dos vazios.

O MEV consegue realizar aumentos de centenas a milhares de vezes das amostras analisadas através da emissão de um feixe de elétrons de alta energia, os quais interagem com a superfície da amostra e refletem a energia para um detector que coleta a informação. Esta técnica possibilita a identificação dos constituintes químicos dos rejeitos mediante o uso do analisador de energia dispersiva (EDS).

Os ensaios foram realizados no Laboratório de Microscopia Eletrônica do Departamento de Engenharia Química e Materiais da PUC-Rio (DEQM), sendo realizados aumentos de 200 e 400 vezes sobre a superfície das amostras de forma cúbica de $0,5 \mathrm{~cm}$ de lado.

As amostras foram previamente levadas à estufa com temperatura de $50^{\circ} \mathrm{C}$, posteriormente, foram submetidos a um bombeamento iônico para deposição de um filme de ouro que melhora a condutividade elétrica da amostra melhorando a imagem em alto vácuo. Após esse tratamento superficial as amostras foram colocadas no microscópio eletrônico JEOL JSM-6510LV (Figura 4.6) com tensão de aceleração de elétrons de $20 \mathrm{kV}$ sendo processadas e armazenadas as imagens.
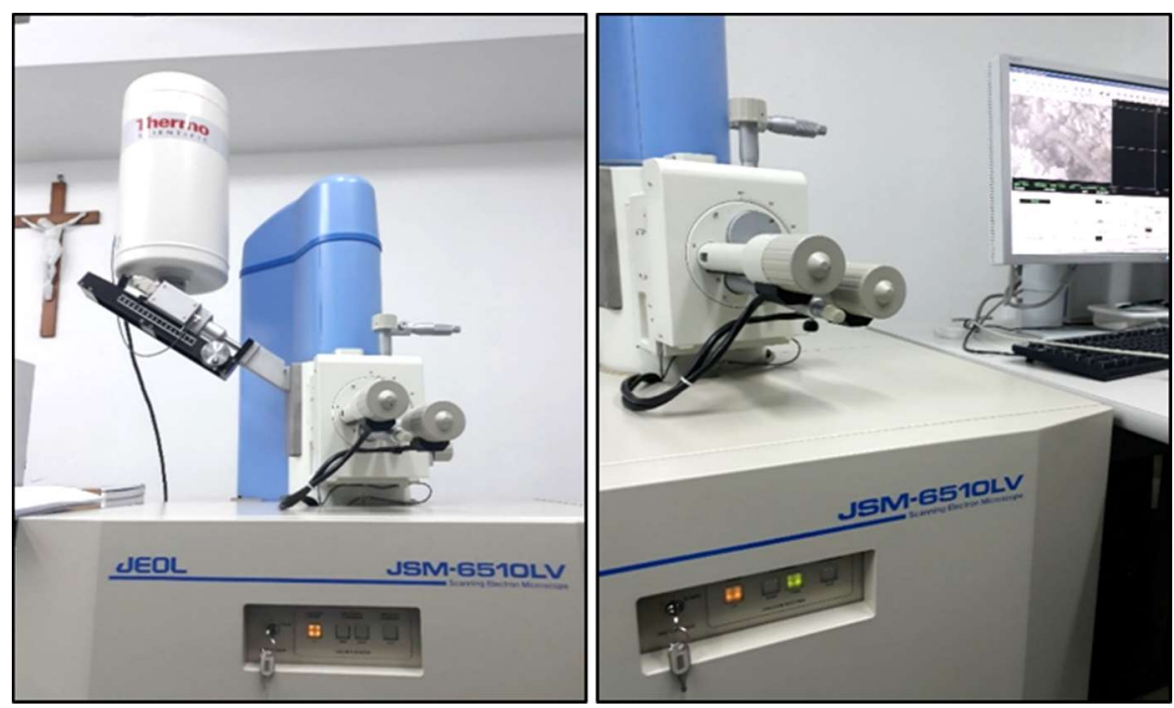

Figura 4.6. Microscopia eletrônica de varredura 
A Figura 4.7 apresenta a imagem do rejeito de minério de ferro com uma fibra de polipropileno saindo da matriz, não se visualizando a presença de nenhum material cimentante, e os microagregados de diferentes tamanhos encontram-se em contato entre eles originando espaços vazios. Nota-se o tamanho e angulosidade dos grãos de rejeito. Sendo o tamanho do grão maior do que da fibra, é possível que os grãos se desloquem ao redor da fibra procurando um melhor arranjo para suportar uma carga externa. Considerando a angulosidade dos grãos, fibras podem ficar presas nos contatos entre grãos sendo submetida à tração durante a deformação axial em ensaios de resistência, assim como também, os grãos poderiam escorregar ao redor da fibra se o arranjo grão-fibra é superado pela tensão desviadora.

$\mathrm{Na}$ análise química (EDS), as porcentagens indicadas nas Figuras são pontuais não representando a análise química total do rejeito. Foram observados 4 pontos da matriz ao redor da fibra mostrando uma maior porcentagem de silício, o que verifica a maior presença de $\mathrm{SiO}_{2}$ encontrada na análise mineralógica, o teor de ferro também se destaca.
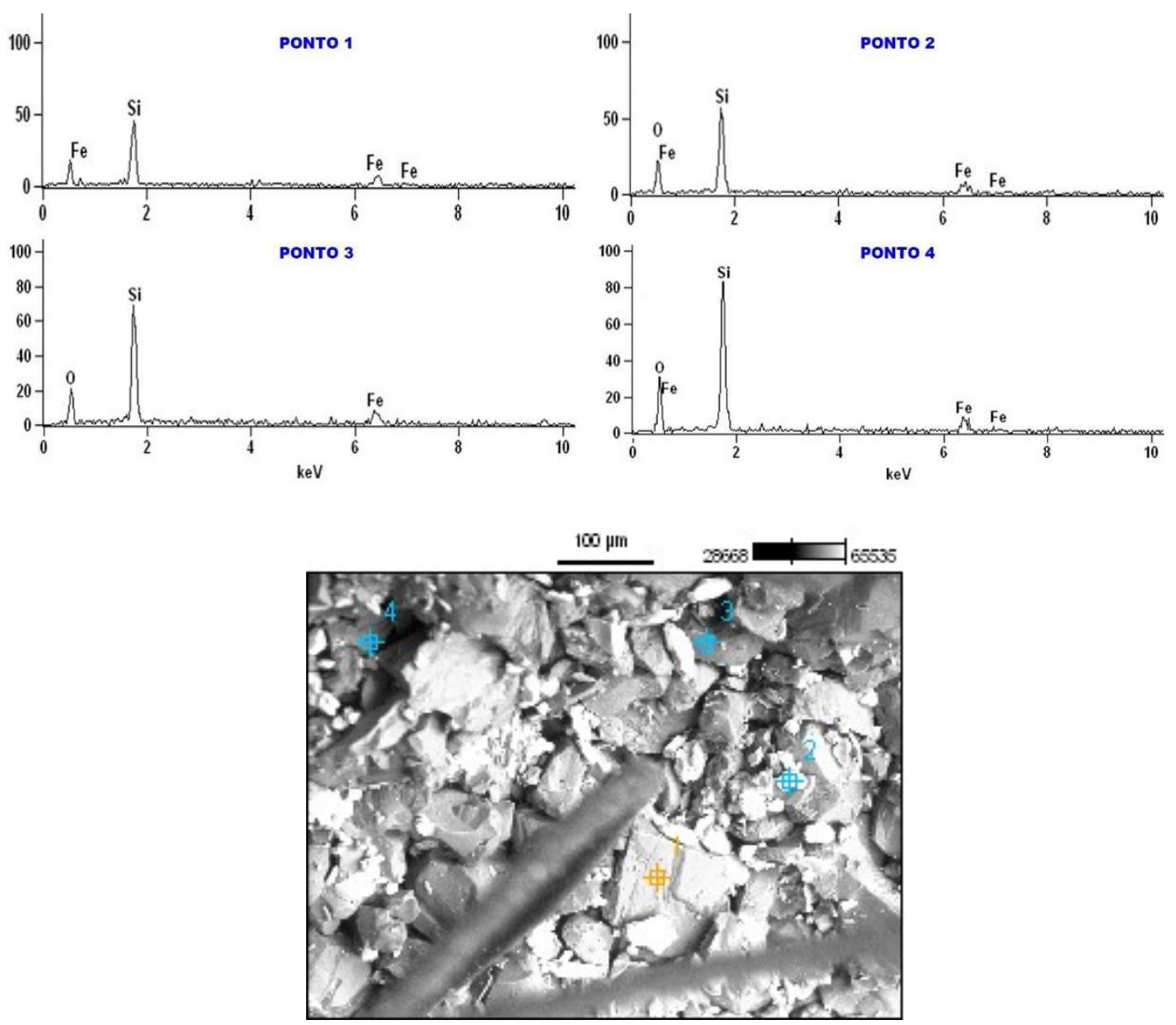

Figura 4.7. Imagem MEV e pontos EDS no rejeito de minério de Ferro 
A Figura 4.8 apresenta a imagem do rejeito de minério de ouro com uma fibra de polipropileno saindo da matriz. Visualiza-se a presença de material cimentante entre os microagregados de diferentes tamanhos, se verificando a existência de microporos entre os microagregados de forma angulosa.

$\mathrm{Na}$ análise química (EDS), foram determinados 4 pontos na matriz ao redor da fibra mostrando uma maior porcentagem de enxofre, o que verifica a maior presença de $\mathrm{SO}_{3}$ encontrada na análise mineralógica, destacando-se o considerável valor para alumínio e silício.
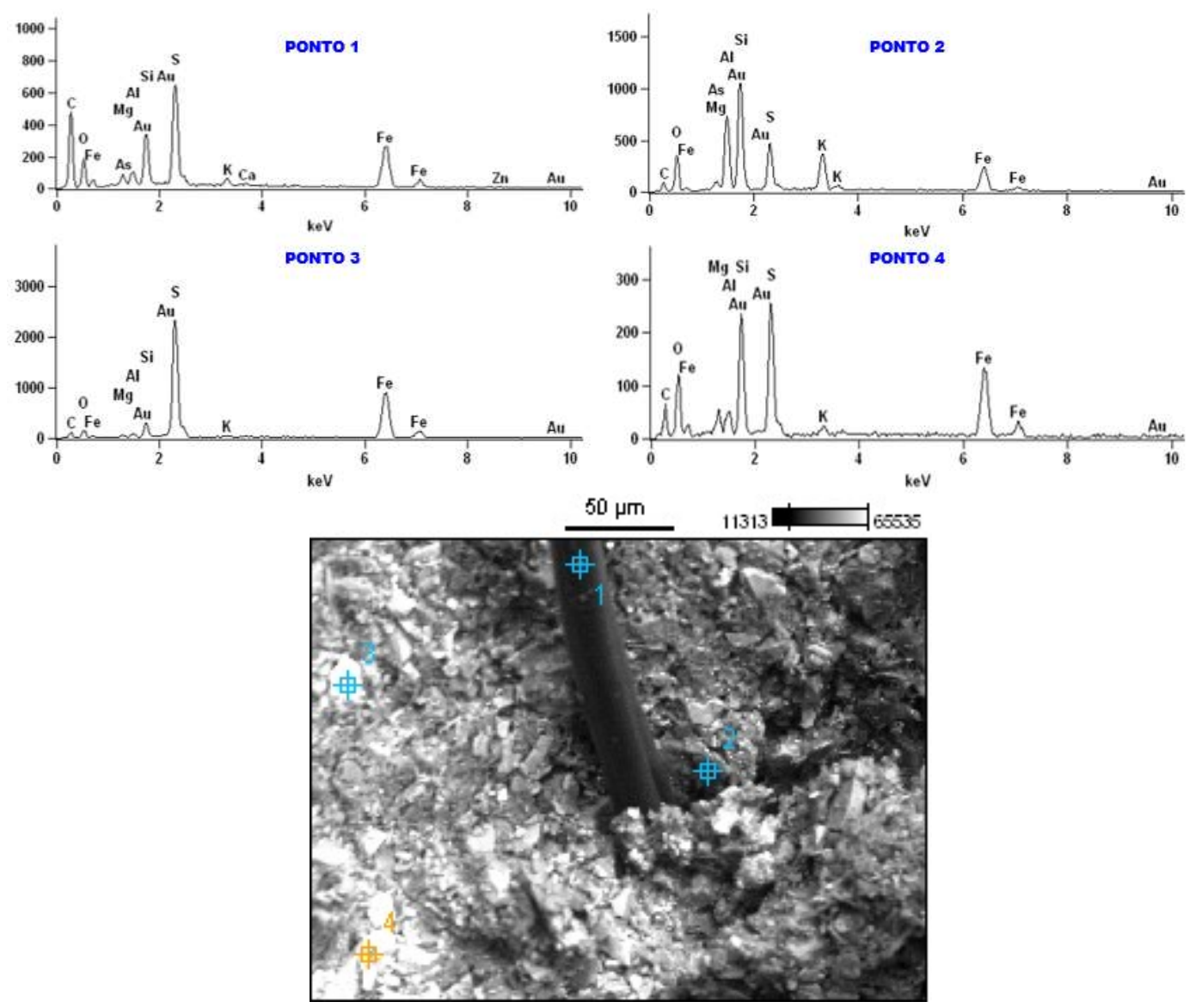

Figura 4.8. Imagem MEV e pontos EDS no rejeito de minério de Ouro

\subsection{7.}

\section{Máxima densidade seca aparente}

O ensaio Proctor é um dos procedimentos mais importantes para o estudo e controle de qualidade da compactação do solo, através dele é possível determinar a densidade seca máxima e o teor de umidade para uma certa energia de compactação. O ensaio de Proctor normal é padronizado pela norma brasileira NBR 7182 (ABNT, 1986-b). 
Em ambos os rejeitos de minério foi possível realizar o ensaio de Proctor Normal, sendo que no caso do rejeito de ferro, por ser uma areia siltosa, não foi possível retirar a amostra compactada para talhar os corpos de prova para os ensaios de resistência. $\mathrm{O}$ ensaio se realizou para determinar o teor ótimo de umidade. Para a moldagem, utilizou-se a técnica de moist tamping onde se coloca o material úmido no molde controlando-se a densidade relativa (item 4.2.8).

O rejeito de minério de ouro é uma argila siltosa que permite retirar a amostra compactada para talhar os corpos de prova. Os dados obtidos neste caso foram a massa máxima aparente seca e o teor ótimo de umidade. A curvas de compactação do rejeito de minério de ferro e ouro são apresentados nas Figuras 4.9 e 4.10, respectivamente. Os valores da densidade máxima seca aparente e o teor ótimo de umidade são mostrados na Tabela 4.8.

Tabela 4.8. Resultados do Proctor Normal

\begin{tabular}{ccc}
\hline $\begin{array}{c}\text { Rejeito de } \\
\text { Minério }\end{array}$ & $\begin{array}{c}\text { Massa máxima } \\
\text { aparente seca } \\
\left(\mathrm{g} / \mathrm{cm}^{3}\right)\end{array}$ & $\begin{array}{c}\text { Teor ótimo de } \\
\text { Umidade }(\%)\end{array}$ \\
\hline Ferro & 1,748 & 12,3 \\
Ouro & 2,239 & 16,0 \\
\hline
\end{tabular}

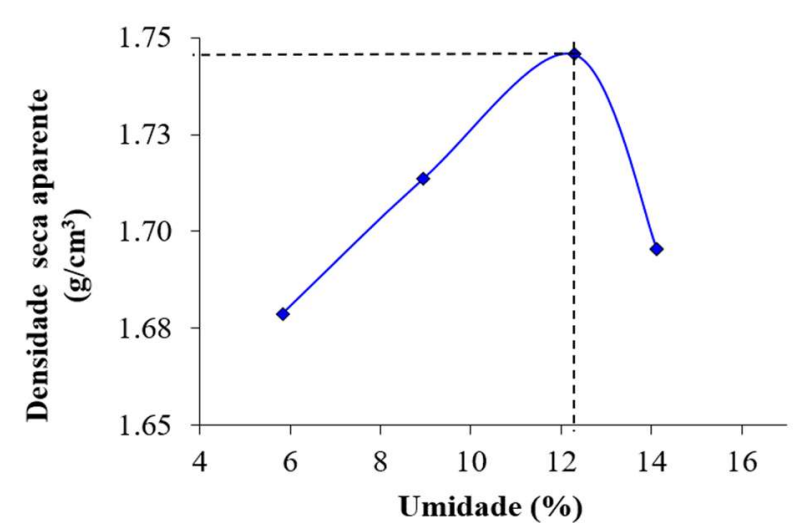

Figura 4.9. Ensaio de Proctor Normal - Rejeito de Minério de Ferro

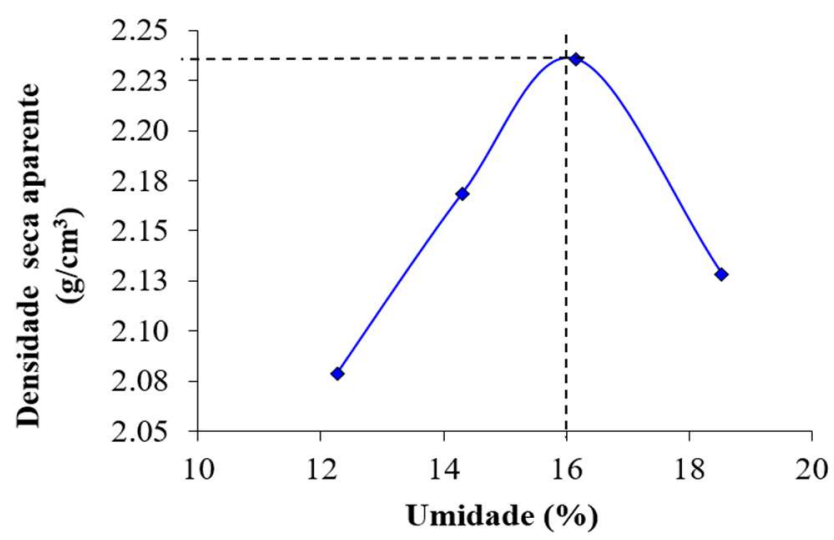

Figura 4.10. Ensaio de Proctor Normal - Rejeito de Minério de Ouro 


\subsection{8.}

\section{Densidade Relativa}

Determinou-se o índice de vazios máximo e mínimo utilizando a norma brasileira NBR12004 (ABNT, 1990) e NBR12051 (ABNT, 1991), respectivamente.

Estas normas determinam os índices de vazios em solos não coesivos que apresentem um teor de finos inferior a $12 \%$, porque contém a consideração que uma quantidade maior de finos pode gerar um efeito coesivo que prejudique o desenvolvimento do ensaio

No rejeito de minério de ferro, a percentagem de finos excede esse valor mas ao serem as partículas de ferro aquelas que compõem a fração fina e tendo sido geradas pelo processo de cominuição possuem angulosidade e alta aspereza, em consequência, o comportamento da fração fina é granular e portanto não coesivo, sendo assim, é possível aplicar as recomendações da norma ao rejeito de minério de ferro (Pressoti, 2002; Rezende, 2013). Os índices de vazios máximo e mínimo são 0,84 e 0,55 , respectivamente.

No campo, o peso dos equipamentos sobre o rejeito de minério de ferro fornece um adensamento médio-denso, em consequência, se trabalhou com uma densidade relativa de $65 \%$.

Utilizando os dados de densidade relativa e os índices de vazios máximo e mínimo, aplicou-se a equação 4.2, calculando-se o índice de vazios e $=0,65$, que foi utilizado para calcular as quantidades de material a serem colocadas dentro dos moldes para ensaios de resistência.

$D_{r}=\frac{e_{\max }-e}{e_{\max }-e_{\min }}$

\subsection{9.}

\section{Permeabilidade}

Conhecer a permeabilidade dos rejeitos de minério é importante porque com baixa permeabilidade um rápido incremento na tensão desviadora pode gerar um incremento de pressão na água intersticial entre os grãos de rejeito que favorece o incremento de poropressão, portanto no curto prazo uma condição não drenada determina o comportamento do rejeito. Os coeficientes de permeabilidade são tanto 
menores quanto menores forem os vazios nos solos que podem estar representados indiretamente pela quantidade de finos.

Ensaios de permeabilidade em permeâmetro de carga constante baseado na NBR 13292 (ABNT, 1995) foram realizados. As amostras compactadas foram colocadas dentro do permeâmetro, sendo saturadas mediante percolação e contrapressão com o intuito de eliminar as bolhas de ar.

Quando o parâmetro B foi de 0,97 , permitiu-se novamente a percolação da água por ascensão aplicando a carga hidráulica de fluxo constante, fazendo-se medidas dos volumes percolados segundo o tempo. Nestes ensaios foram feitas várias medidas de permeabilidade utilizando a média delas para descrever cada rejeito.

A Tabela 4.9 mostra as medições e o coeficiente de permeabilidade final dos rejeitos de minério.

Tabela 4.9. Permeabilidade

\begin{tabular}{|c|c|c|}
\hline \multirow[t]{2}{*}{ Medição } & \multicolumn{2}{|c|}{$\begin{array}{c}\text { Permeabilidade } \\
(\mathrm{m} / \mathrm{s})\end{array}$} \\
\hline & Ferro & Ouro \\
\hline 01 & $2,63 \times 10^{-6}$ & $1,15 \times 10^{-6}$ \\
\hline 02 & $2,15 \times 10^{-6}$ & $1,25 \times 10^{-6}$ \\
\hline 03 & $1,97 \times 10^{-6}$ & $1,08 \times 10^{-6}$ \\
\hline 04 & $2,47 \times 10^{-6}$ & $1,32 \times 10^{-6}$ \\
\hline 05 & $2,01 \times 10^{-6}$ & $1,57 \times 10^{-6}$ \\
\hline Desvio Padrão & 0,291 & 0,189 \\
\hline Média & $2,246 \times 10^{-6}$ & $1,27 \times 10^{-6}$ \\
\hline
\end{tabular}

Ambos os rejeitos de minério de ferro e ouro possuem uma baixa permeabilidade, portanto em curto prazo é importante estudar a resposta não drenada para ver a variação de poropressão e como isto afeta à resistência ao cisalhamento não reforçado e reforçado, embora em longo prazo, a resposta drenada é a condição que permanecerá, portanto, é importante avaliar em ambos os rejeitos a condição drenada e não drenada mediante ensaios triaxiais.

\section{3.}

\section{Caracterização das Fibras de reforço}

Como foi mencionado no item 4.2.4, fibras sintéticas de polipropileno foram selecionadas para reforçar os rejeitos de mineração pela resistência ao ataque álcali e ácido que possuem. Para facilitar sua obtenção procurou-se uma parceria com a Maccaferri, um distribuidor local que fornece diferentes tamanhos de fibra. 
Os ensaios triaxiais foram realizados em corpos de prova de $10 \mathrm{~cm}$ de altura e $5 \mathrm{~cm}$ de diâmetro, deste modo para assegurar uma boa distribuição das fibras o comprimento destas deve ser menor que o diâmetro da amostra. Fibras de $24 \mathrm{~mm}$ de comprimento foram selecionadas.

Para evitar a contaminação das fibras, estas foram entregues dentro de sacos hidrossolúveis de $600 \mathrm{~g}$. Na apresentação comercial, as fibras se encontram formando pacotes de aproximadamente $5 \mathrm{~g}$ como mostra a Figura 4.11. A Tabela 4.10 apresenta as principais características técnicas da fibra fornecida pelo fabricante.

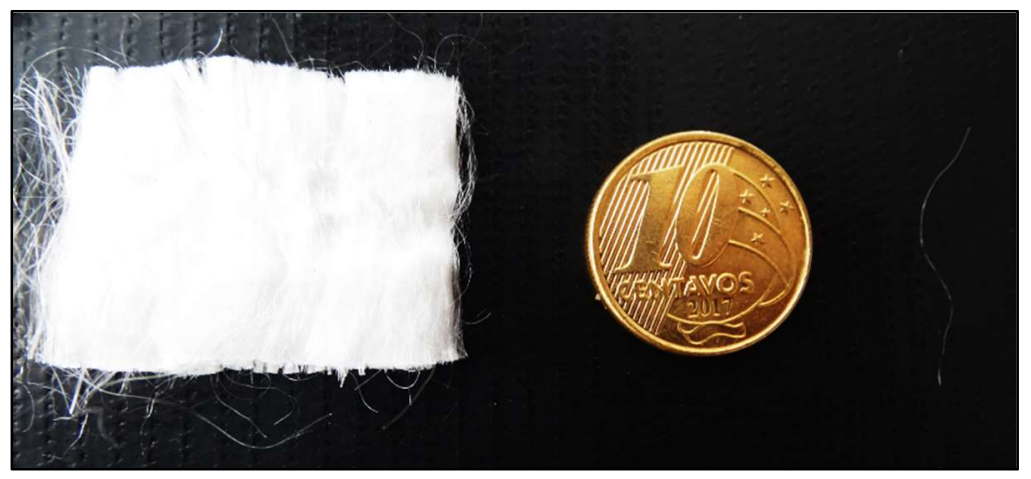

Figura 4.11. Fibras de polipropileno

Tabela 4.10. Características técnicas das fibras de polipropileno

\begin{tabular}{l|c|c}
\hline Propriedades físicas & Unidade & Valor \\
\hline Diâmetro & $\mu \mathrm{m}$ & 18 \\
Seção & $\mathrm{mm}$ & $\begin{array}{c}24 \\
\text { circular } \\
\text { Comprimento }\end{array}$ \\
Matéria Prima & & 0,91 \\
Peso específico & $\mathrm{g} / \mathrm{cm}^{3}$ & \\
\hline Propriedade Mecânicas & & 160 \\
\hline Temperatura de fusão & ${ }^{\circ} \mathrm{C}$ & 365 \\
Temperatura de Ignição & ${ }^{\circ} \mathrm{C}$ & 300 \\
Resistência à tração & $\mathrm{MPa}\left(\mathrm{N} / \mathrm{mm}^{2}\right)$ & 3000 \\
Módulo de Young & $\mathrm{MPa}$ & \\
\hline
\end{tabular}

Para realizar a verificação da resistência à tração dada pelo fabricante foram selecionadas 4 sacolas diferentes retirando um pacote de fibras de cada uma delas.

De cada pacote, dez (10) fibras foram desfiadas e colocadas em janelas de papel para serem adaptadas às garras do equipamento de ensaios a tração (Figura 4.12). 
Finalmente, quarenta (40) fios de polipropileno foram grudados ao papel e selados com fita adesiva de alta resistência para evitar o escorregamento nas garras, após a colocação das janelas de tração, o papel era cortado no eixo horizontal central e o ensaio iniciava.

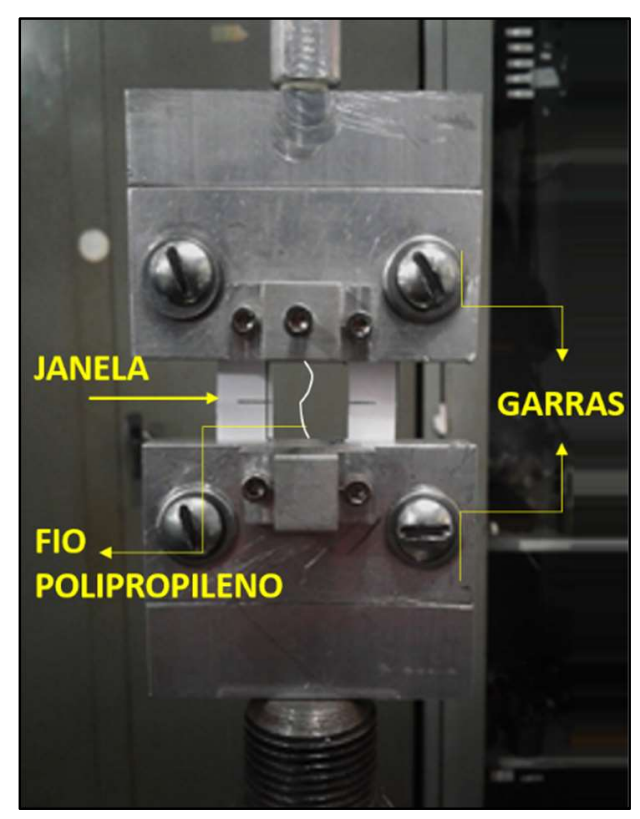

Figura 4.12. Ensaio de tração em fibras de polipropileno

Durante os ensaios 5 amostras foram perdidas pelo manuseio das janelas. A velocidade de ensaio foi de $50 \mathrm{~mm} / \mathrm{min}$.

Os ensaios foram feitos no Laboratório da BMDTexteis localizado no estado da Bahia.

Tabela 4.11. Valores resistência à tração em fibras de polipropileno

\begin{tabular}{ccccc}
\hline Valor & $\begin{array}{c}\text { Tração de } \\
\text { ruptura } \\
(\mathrm{gf})\end{array}$ & $\begin{array}{c}\text { Deformação } \\
\text { na ruptura } \\
(\%)\end{array}$ & $\begin{array}{c}\text { Força na } \\
\text { ruptura } \\
(\mathrm{N})\end{array}$ & $\begin{array}{c}\text { Tensão na } \\
\text { ruptura } \\
\left(\mathrm{N} / \mathrm{mm}^{2}\right)\end{array}$ \\
\hline Média & 17,17 & 8,65 & 0,17 & 661,7 \\
Médiana & 15,20 & 8,74 & 0,15 & 585,8 \\
Mínimo & 8,44 & 0,59 & 0,08 & 325,3 \\
Máximo & 32,08 & 15,98 & 0,31 & 1236,3 \\
\hline
\end{tabular}

É possível verificar na Tabela 4.11 que a resistência à tração mínima das fibras de polipropileno à ruptura $(325 \mathrm{MPa})$ é coerente com a resistência fornecida pelo fabricante (300 MPa). 


\section{4. \\ Discussão dos Resultados}

Neste item, realiza-se um resumo e análise dos resultados obtidos na caracterização dos rejeitos de minério de ferro e ouro mostrados na Figura 4.13. A Tabela 4.12 é importante, pois mostra as diferenças entre os tipos de rejeitos escolhidos e que, no momento da avaliação do compósito, auxiliará no maior entendimento do comportamento entre rejeitos sob as condições drenadas e não drenadas.

Tabela 4.12. Resumo dos resultados de caracterização

\begin{tabular}{|c|c|c|c|}
\hline \multirow{2}{*}{ Item } & \multirow{2}{*}{ Unidade } & \multicolumn{2}{|c|}{ Rejeito de Minério } \\
\hline & & Ferro & Ouro \\
\hline Argila & $\%$ & 1,70 & 26,52 \\
\hline Silte & $\%$ & 16,03 & 71,61 \\
\hline Areia Fina & $\%$ & 70,56 & 1,87 \\
\hline $\mathrm{D}_{10}$ & $\mathrm{~mm}$ & 0,049 & 0,0008 \\
\hline $\mathrm{D}_{30}$ & $\mathrm{~mm}$ & 0,074 & 0,0033 \\
\hline $\mathrm{D}_{50}$ & $\mathrm{~mm}$ & 0,100 & 0,0076 \\
\hline $\mathrm{D}_{60}$ & $\mathrm{~mm}$ & 0,125 & 0,0098 \\
\hline $\mathrm{C}_{\mathrm{u}}$ & - & 1,5 & - \\
\hline $\mathrm{C}_{\mathrm{c}}$ & - & 0,9 & - \\
\hline LL & $\%$ & - & 19 \\
\hline LP & $\%$ & - & 13 \\
\hline IP & $\%$ & - & 6 \\
\hline $\mathrm{I}_{\mathrm{a}}$ & - & - & Inativa \\
\hline $\mathrm{G}_{\mathrm{s}}$ & - & 2,89 & 3,77 \\
\hline $\mathrm{pH}$ & - & Alcalino & Ácido \\
\hline $\mathrm{SiO}_{2}$ & $\%$ & 82,67 & 31,64 \\
\hline $\mathrm{SO}_{3}$ & $\%$ & 0,00 & 30,40 \\
\hline $\mathrm{Fe}_{2} \mathrm{O}_{3}$ & $\%$ & 12,91 & 15,6 \\
\hline Moldagem & - & Moist Tamping & Proctor Normal \\
\hline Massa específico seca & $\mathrm{g} / \mathrm{cm}^{3}$ & 1,75 & 2,24 \\
\hline Teor de umidade & $\%$ & 12,3 & 16,0 \\
\hline Dr & $\%$ & 65 & - \\
\hline $\mathrm{k}$ & $\mathrm{m} / \mathrm{s}$ & $2,2 \times 10^{-6}$ & $1,3 \times 10^{-6}$ \\
\hline
\end{tabular}

Diambra \& Ibraim (2015) advertiram que as características geométricas, o comprimento/diâmetro da fibra, e o tamanho das partículas granulares formam um conjunto especial de parâmetros inter-relacionados. A literatura indica que enquanto se mantém constante a razão de aspecto da fibra, o efeito das fibras é maior com a redução do tamanho da partícula (Gray \& Al-Refeai, 1986; Maher \& Gray, 1990; Ranjan et al., 1996; Michałowski \& Čermák, 2003), não obstante, essas alusões são para areias e tem que ser adotadas com cautela para o rejeito de minério de ouro. Nota-se que o diâmetro efetivo $\left(\mathrm{D}_{10}\right)$ do rejeito de minério de ouro é 60 vezes menor do que o rejeito de ferro. 


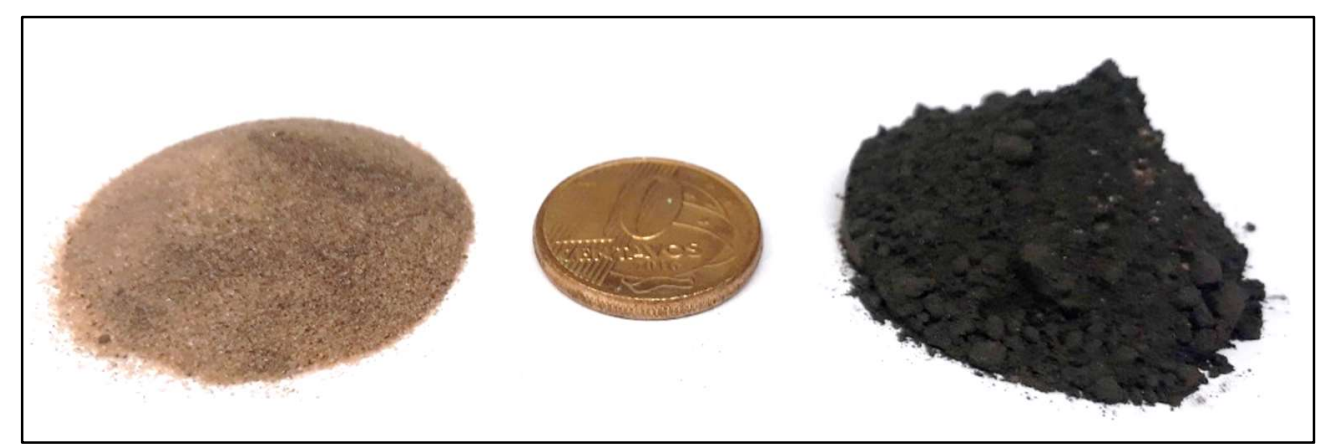

Figura 4.13. Rejeito de Minério de Ferro e de Ouro

Os coeficientes de uniformidade e curvatura indicam que o rejeito de minério de ferro é muito uniforme e mal graduado. A uniformidade é considerada como uma característica que não resulta em um bom entrosamento à estrutura do material, pois arranjos de partículas uniformes admitem maiores vazios, como mostra a Figura 4.14. Os grãos do rejeito de minério de ferro são angulosos, como mostram as análises MEV, e podem conseguir um melhor arranjo além de que pode ocorrer quebra de grãos nos pontos de contato, ocupando essas micropartículas os espaços vazios.

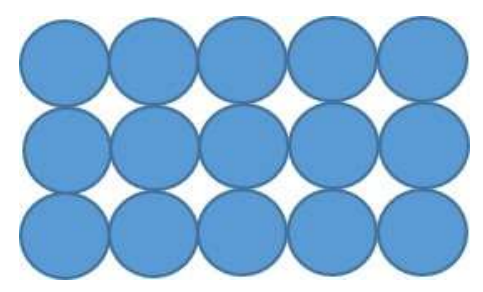

$\mathrm{Cu}<5$

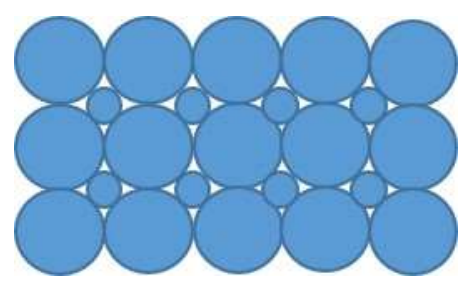

$5<\mathrm{Cu}<15$

Figura 4.14. Coeficiente de uniformidade

As fibras de polipropileno possuem um diâmetro de $0,018 \mathrm{~mm}$, portanto, o $95 \%$ dos grãos de rejeito de ferro são maiores que as fibras. Supondo que fibras podem ser consideradas como correntes de esferas idênticas em contato, com diâmetro de $18 \mu \mathrm{m}$, podem ocupar os espaços entre os grãos de rejeito densificando a matriz. Matrizes granulares densas possuem comportamento dilatante, portanto, a adição da fibra neste caso, geraria um efeito que incrementaria esse comportamento.

O caso do rejeito de minério de ouro é totalmente diferente, já que $80 \%$ da matriz fina é menor do que o diâmetro da fibra, portanto a fibra seria um elemento que incrementaria a porosidade da matriz. O rejeito de minério de ouro é classificado como uma argila siltosa, no entanto, o que determina o comportamento 
argiloso não é só o teor de argila, mas sim a atividade, no item 4.2.2, observou-se que o rejeito é inativo.

A procedência das partículas de tamanho argila, originadas pelo processo agressivo de desgaste físico e químico das rochas, abre a possibilidade de que o comportamento mecânico e/ou volumétrico não seja o esperado. O comportamento de argilas normalmente adensadas é bastante semelhante ao de areias fofas, porém, pelo mostrado anteriormente, é necessário realizar ensaios triaxiais para conferir esse comportamento pela diferente gênese dos rejeitos comparados com argilas naturais.

Assumindo que o comportamento seja o de areia fofa, as fibras sendo de diâmetro maior do que o diâmetro médio $\left(\mathrm{D}_{50}\right)$ da matriz, podem gerar o efeito contrário ao caso do rejeito de ferro, gerando maiores vazios sobretudo na interfase com a matriz, portanto, favorecendo um comportamento contrativo durante o carregamento. As Figuras 4.15 e 4.16 mostram a interação da fibra com os grãos de rejeito de minério de ferro e ouro, respectivamente.

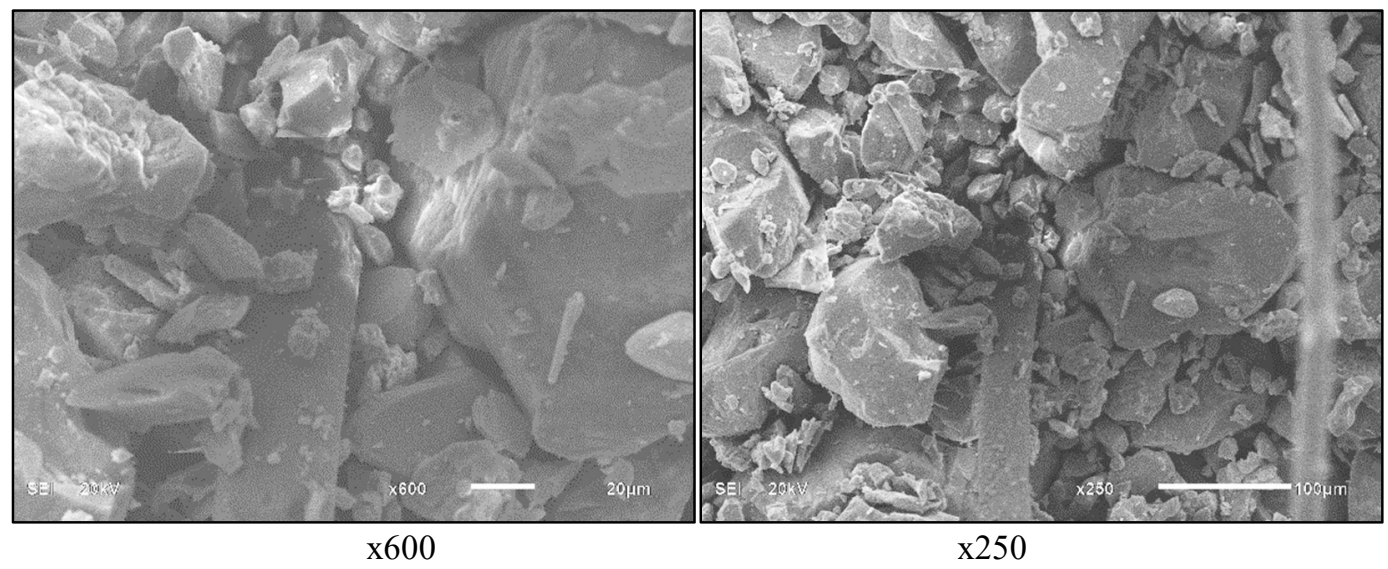

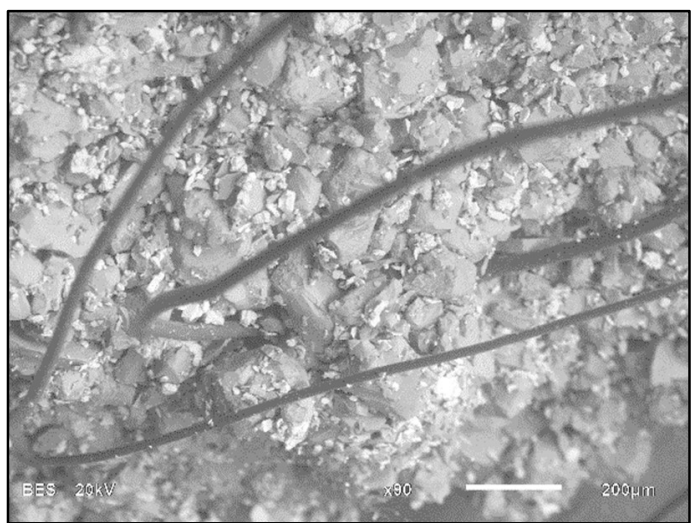

x90

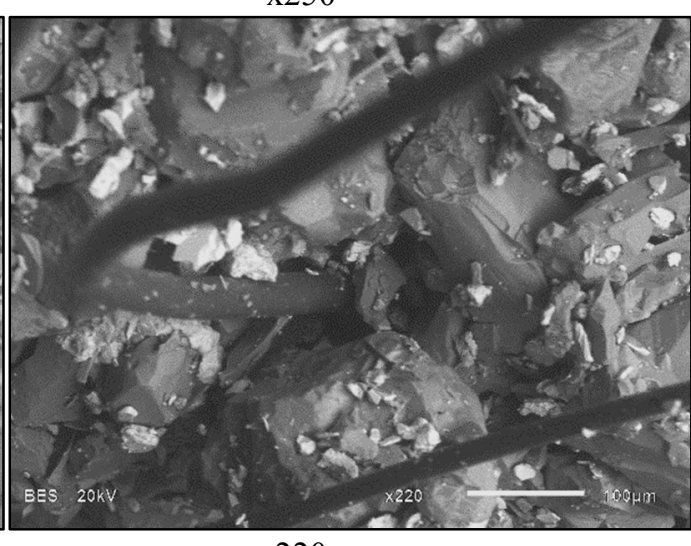

$\mathrm{x} 220$

Figura 4.15. Interação Fibra-Rejeito de Minério de Ferro 


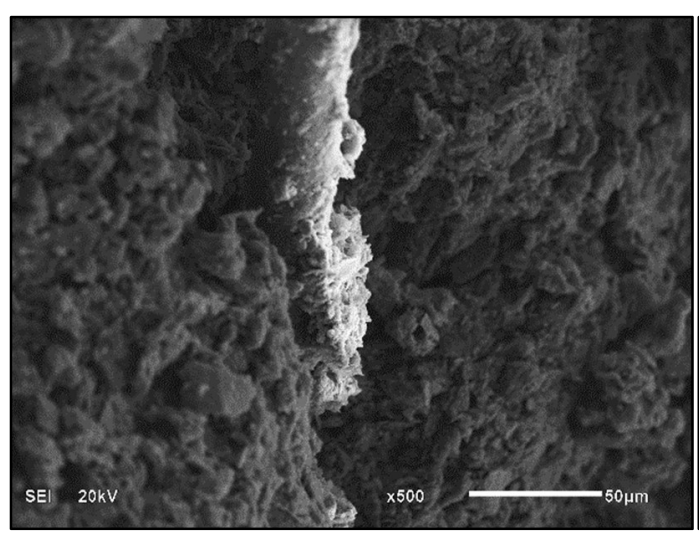

$\times 500$

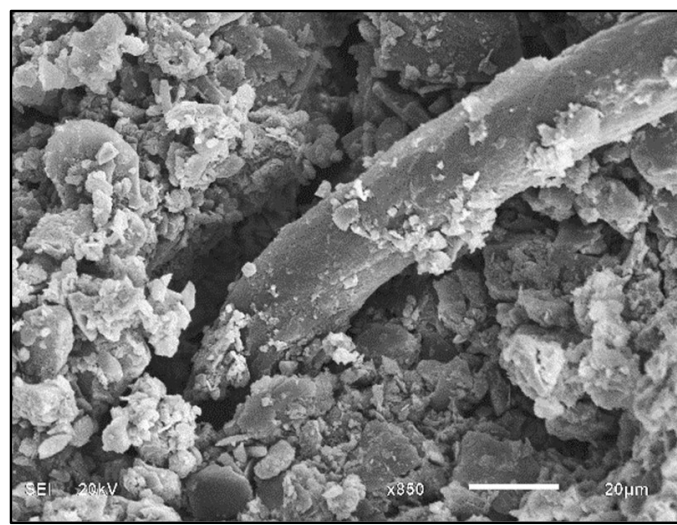

$\mathrm{x} 850$

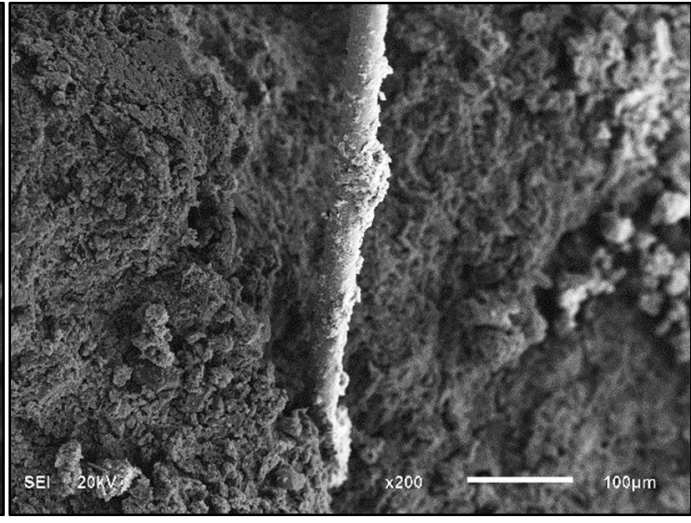

$\mathrm{x} 200$

Figura 4.16. Interação Fibra-Rejeito de Minério de Ouro

$\mathrm{Na}$ Figura 4.15, observa-se a diferença entre os grãos de rejeito de ferro e o diâmetro da fibra, destaca que a fibra forma parte do entrosamento do rejeito, não segregando material, pois partículas de diferentes tamanhos se encontram ao redor dela. Na parte inferior das imagens aparecem as ampliações feitas para melhorar a visibilidade da interface fibra-rejeito. Na Figura 4.16, nota-se que na superfície da fibra aparecem coladas partículas do rejeito de minério de ouro mostrando uma certa aderência, destacando a abertura que deixa a fibra na interface com a matriz, indicando a descontinuidade da matriz.

\section{5.}

\section{Considerações Finais}

Neste item são apresentadas brevemente as conclusões obtidas no desenvolvimento deste capítulo.

As análises de fluorescência foram verificadas com os resultados do analisador de energia dispersiva, confirmando a procedência dos rejeitos de minério. 
As medições do potencial hidrogeniônico mostraram que o rejeito de minério de ferro e ouro possuem um $\mathrm{pH}$ alcalino e ácido, respectivamente. As fibras de polipropileno são idôneas para serem usadas neste tipo de matrizes, pois possuem resistência ao ataque álcali e resistência alta em ambientes com ácidos e sais.

Os ensaios de tração realizados em 35 amostras de fibras polipropileno verificam uma resistência mínima à tração de $300 \mathrm{MPa}$.

As imagens obtidas pelo método de Microscopia eletrônica de varredura (MEV) mostram em detalhe a interação na interface entre a fibra e a matriz dos rejeitos de minério de ferro e ouro.

Observa-se que a inclusão de fibras pode densificar a matriz no caso do rejeito de minério de ferro e aumentar a porosidade no caso do rejeito de minério de ouro.

Fibras favorecem o entrosamento no rejeito de minério de ferro, enquanto no rejeito de minério de ouro podem gerar maiores vazios.

Ambos os rejeitos apresentaram uma baixa permeabilidade na ordem de grandeza de $10^{-6} \mathrm{~m} / \mathrm{s}$, portanto ensaios não drenados são importantes para descrever o comportamento a curto prazo, enquanto os ensaios drenados para longo prazo. 


\section{5. \\ Apresentação e discussão dos Resultados}

5.1.

Ensaios triaxiais

O programa de ensaios triaxiais drenados e não drenados foi feito sob tensões efetivas de confinamento de 50,100, 200 e $400 \mathrm{kPa}$.

Nos cálculos não foi considerada a correção da tensão pela influência da membrana de látex, pois o valor da correção seria desprezível com relação ao valor da resistência ao cisalhamento obtida. A correção da área foi realizada utilizando a fórmula proposta por Bishop \& Henkel (1962) considerando que a ruptura no final de cada ensaio foi do tipo plástica com as amostras apresentando um "embarrigamento".

Para definir o instante da ruptura utilizou-se o valor máximo da tensão desviadora $\left(\mathrm{q}_{\max }\right)$. Nos casos onde a tensão desviadora não apresentou um pico pelo comportamento strain-hardening, utilizou-se a razão de tensões efetivas $\left(\sigma^{\prime}{ }_{1} / \sigma^{\prime}{ }_{3}\right)$ vs. deslocamento axial, utilizando o ponto máximo $\left(\sigma_{1}{ }_{1} / \sigma^{\prime}{ }_{3}\right)$ máx., para descrever o começo da ruptura, nos casos onde não existe uma razão de pico, o fissuramento da matriz foi considerado quando a inclinação deste gráfico muda.

Obras de engenharia normalmente trabalham com rupturas da ordem de $5 \%$ de deformação, portanto, este critério de começo de fissuramento fornece uma melhor comparação entre amostras não reforçadas e reforçadas na tensão de ruptura, do que comparar a máxima tensão desviadora que no caso reforçado, vai ser maior do que $20 \%$ de deformação axial, segundo os resultados.

Para mostrar a aptidão deste critério e a variação nos parâmetros de resistência apresentam-se no item 5.1.4.2 as envoltórias de resistência nos casos não reforçado e reforçado, com os pontos no começo da fissuração da matriz $\left(\sigma^{\prime}{ }_{1} / \sigma^{\prime}{ }_{3}\right)_{\text {pend., }}$ e com os pontos em $20 \%$ de deformação axial. Todos os parâmetros de resistência foram calculados usando o Modelo de Cambridge. 


\subsection{1. \\ Rejeito de Minério de Ferro (RMFe)}

\subsubsection{1. Ensaio triaxial drenado (CD)}

Neste item são apresentados os resultados dos ensaios triaxiais drenados realizados no rejeito de minério de ferro não reforçado e reforçado.

$\mathrm{Na}$ Tabela 5.1 apresentam-se os dados de teor de umidade, peso específico, índice de vazios, porosidade e saturação inicial seguidos do índice de vazios após o adensamento e no final do ensaio, junto com o teor de umidade final.

Tabela 5.1. Variação dos índices físicos CD (RMFe) Rejeito de Minério de Ferro

\begin{tabular}{|c|c|c|c|c|c|c|c|c|c|c|}
\hline \multirow{2}{*}{ Ensaio } & \multirow{2}{*}{$\begin{array}{l}\sigma_{3}^{\prime} \\
\mathrm{kPa}\end{array}$} & \multicolumn{6}{|c|}{$\begin{array}{c}\text { Índices físicos } \\
\text { Iniciais } \\
\end{array}$} & \multirow{2}{*}{$\begin{array}{c}\begin{array}{c}\text { Após o } \\
\text { adensamento }\end{array} \\
\mathrm{e}_{\text {adens. }}\end{array}$} & \multicolumn{2}{|c|}{$\begin{array}{c}\text { Índices Físicos } \\
\text { Finais } \\
\end{array}$} \\
\hline & & $\begin{array}{l}\mathrm{W}_{\mathrm{o}} \\
\%\end{array}$ & $\begin{array}{c}\gamma_{\mathrm{n}} \\
\mathrm{kN} / \mathrm{m}^{3}\end{array}$ & $\begin{array}{c}\gamma_{\mathrm{d}} \\
\mathrm{kN} / \mathrm{m}^{3}\end{array}$ & $\mathrm{e}_{\mathrm{o}}$ & $\begin{array}{l}\mathrm{n} \\
\%\end{array}$ & $\begin{array}{l}\mathrm{S} \\
\%\end{array}$ & & $e_{f}$ & $\begin{array}{l}\mathrm{W}_{\mathrm{f}} \\
\%\end{array}$ \\
\hline e-CID- 50-sf & 50 & 12,73 & 19,67 & 17,45 & 0,658 & 39,68 & 55,97 & 0,652 & 0,719 & 23,73 \\
\hline تe-CID-100-sf & 100 & 12,50 & 19,66 & 17,47 & 0,655 & 39,59 & 55,15 & 0,642 & 0,678 & 22,40 \\
\hline ت-CID-200-sf & 200 & 12,38 & 19,67 & 17,50 & 0,653 & 39,49 & 54,85 & 0,636 & 0,652 & 22,22 \\
\hline$\cong$ ت-CID-400-sf & 400 & 12,34 & 19,67 & 17,51 & 0,652 & 39,45 & 54,77 & 0,616 & 0,621 & 22,26 \\
\hline$\stackrel{\text { I }}{ \pm}$ e-CID- 50-cf & 50 & 12,64 & 19,76 & 17,54 & 0.649 & 39,36 & 56,33 & 0,640 & 0,764 & 22,75 \\
\hline Z E-CID-100-cf & 100 & 12,60 & 19,73 & 17,53 & 0,650 & 39,25 & 56,04 & 0,631 & 0,728 & 22,25 \\
\hline ت⿹ & 200 & 12,55 & 19,77 & 17,57 & 0,646 & 39,27 & 56,17 & 0,621 & 0,694 & 22,57 \\
\hline e-CID-400-cf & 400 & 12,40 & 19,75 & 17,57 & 0,646 & 39,24 & 55,55 & 0,601 & 0,651 & 22,78 \\
\hline
\end{tabular}

As Figuras 5.1 e 5.2 apresentam os resultados do rejeito de minério de ferro não reforçado e reforçado, correspondentes aos ensaios drenados: (a) q vs. $\varepsilon_{\mathrm{a}}$, (b) q vs. p', (c) $\varepsilon_{\mathrm{v}}$ vs. $\varepsilon_{\mathrm{a}}$, (d) e vs. p', (e) q/ $\sigma^{\prime}{ }_{3 \mathrm{c}}$ vs. $\varepsilon_{\mathrm{a}}$, (f) $\sigma^{\prime}{ }_{1} / \sigma^{\prime}{ }_{3}$ vs. $\varepsilon_{\mathrm{a}}$, onde: deformação $\mathrm{axial}=\varepsilon_{\mathrm{a}}$, deformação volumétrica $=\varepsilon_{\mathrm{v}}$, índice de vazios $=\mathrm{e}$, tensão efetiva média $p^{\prime}=\left(\left(\sigma^{\prime}{ }_{1}+2 \sigma^{\prime}{ }_{3}\right) / 3\right)$, tensão desviadora $q=\left(\sigma^{\prime}{ }_{1}-\sigma^{\prime}{ }_{3}\right)$, tensão efetiva de confinamento $=\sigma_{3 c}^{\prime}$ e razão de tensões efetivas principais $=\sigma^{\prime}{ }_{1} / \sigma^{\prime}{ }_{3}$.

No rejeito de minério de ferro não reforçado, as curvas tensão desviadora vs. deformação axial, na Figura 5.1(a), mostram uma ruptura frágil pela presença de picos de resistência em todos os ensaios. Apresentou-se um aumento de rigidez consistente com o aumento da tensão efetiva de confinamento.

As deformações volumétricas na Figura 5.1(c) mostraram uma tendência inicial à compressão suprimida na faixa de 0,35 a $1,30 \%$, que passou a ser claramente de dilatação em todos os ensaios, chegando a não variar mais nas tensões efetivas de 200 e $400 \mathrm{kPa}$ entre 8 e 4\% de deformação axial, respectivamente. 


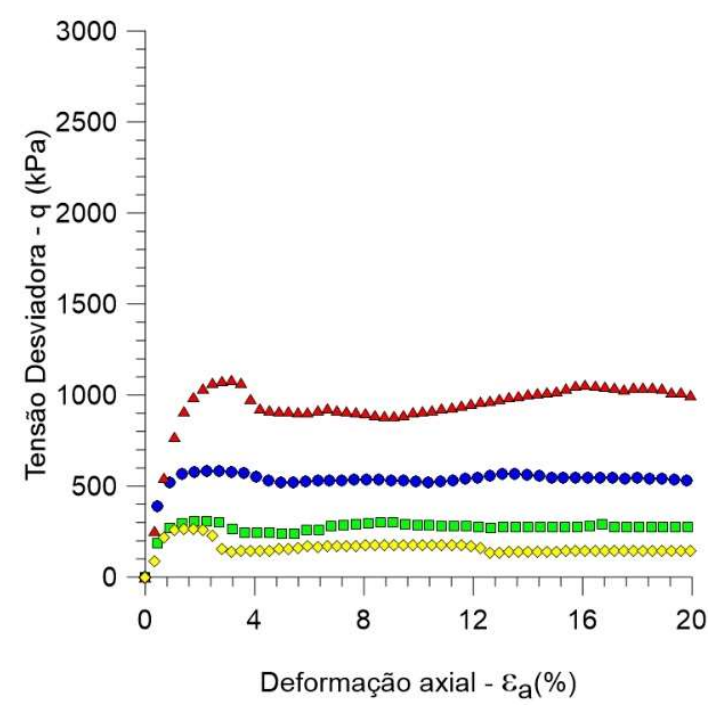

(a)

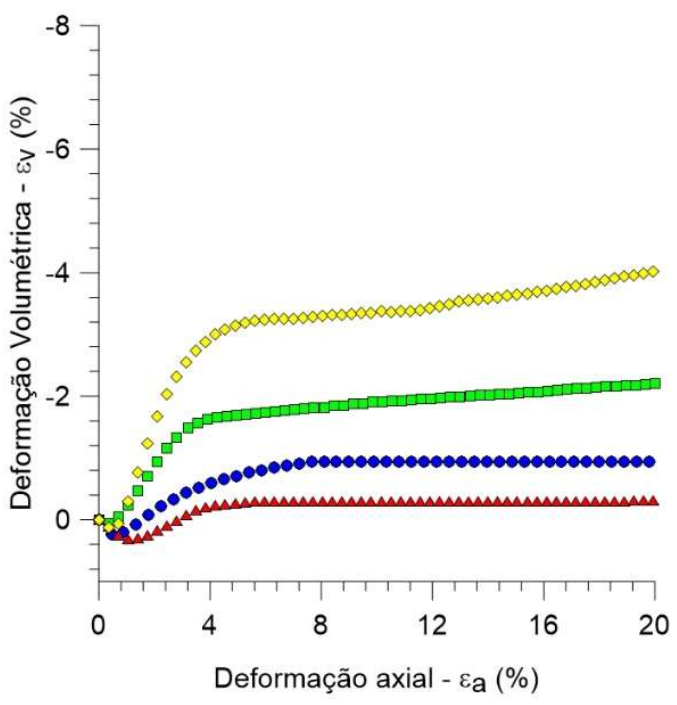

(c)

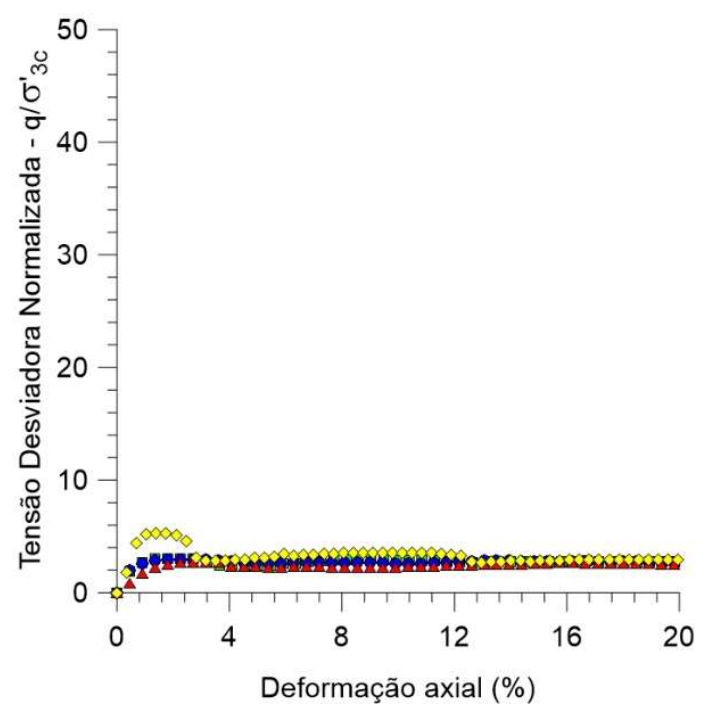

(e)

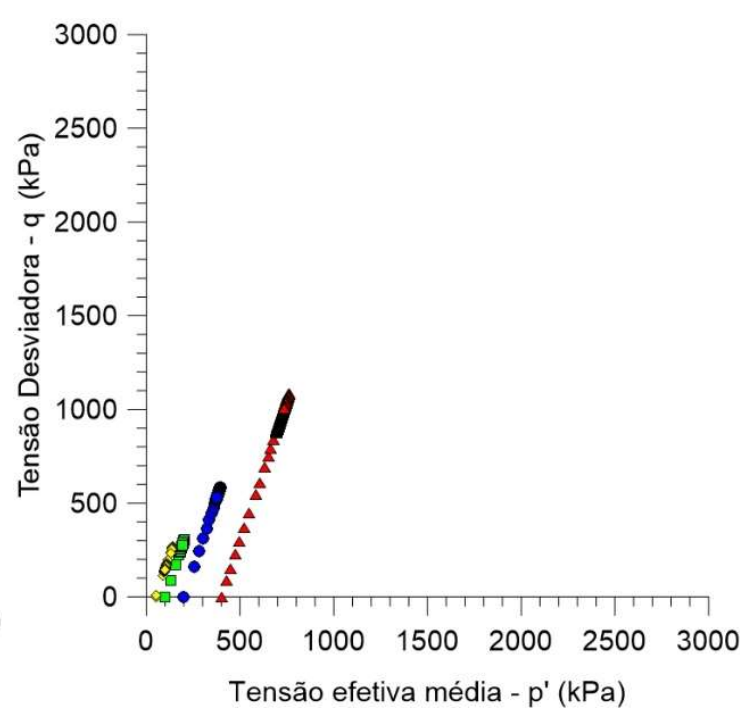

(b)

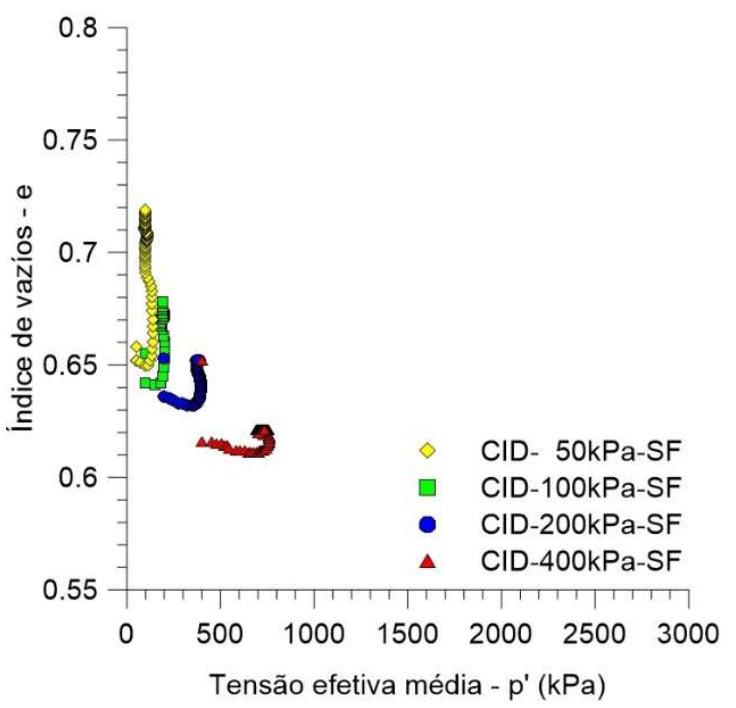

(d)

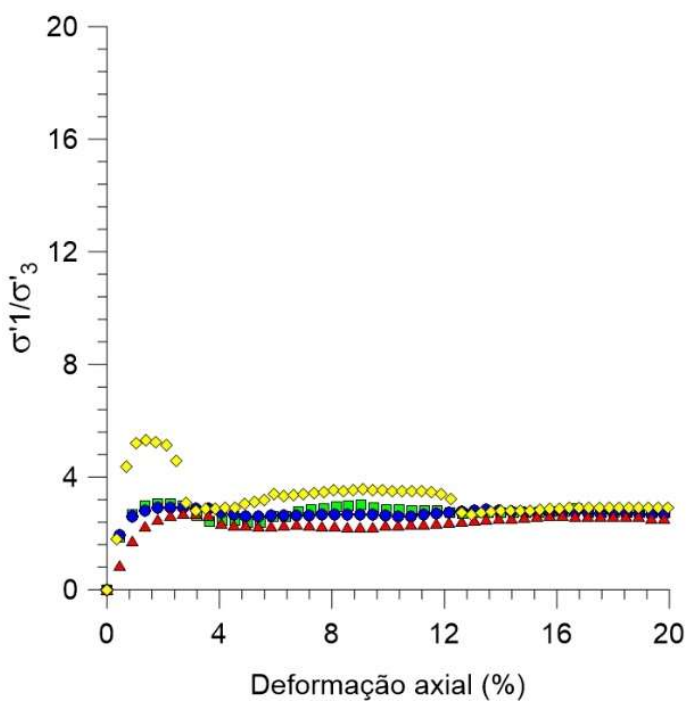

(f)

Figura 5.1. Resultados dos ensaios triaxiais não reforçado $\mathrm{CD}$ (RMFe) Rejeito de Minério de Ferro 


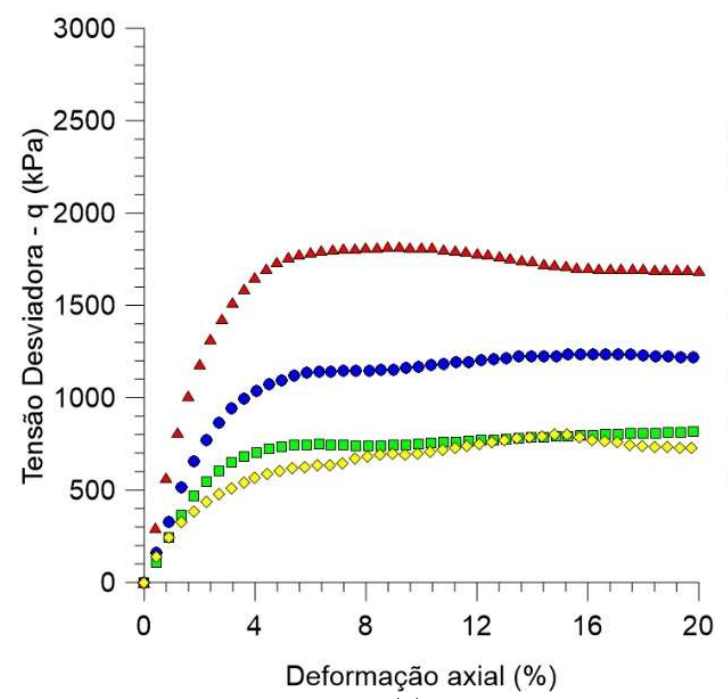

(a)

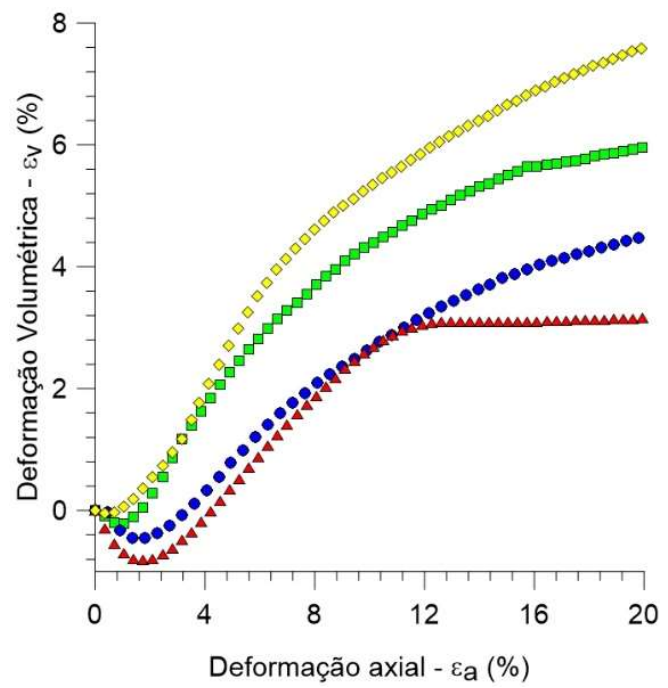

(c)

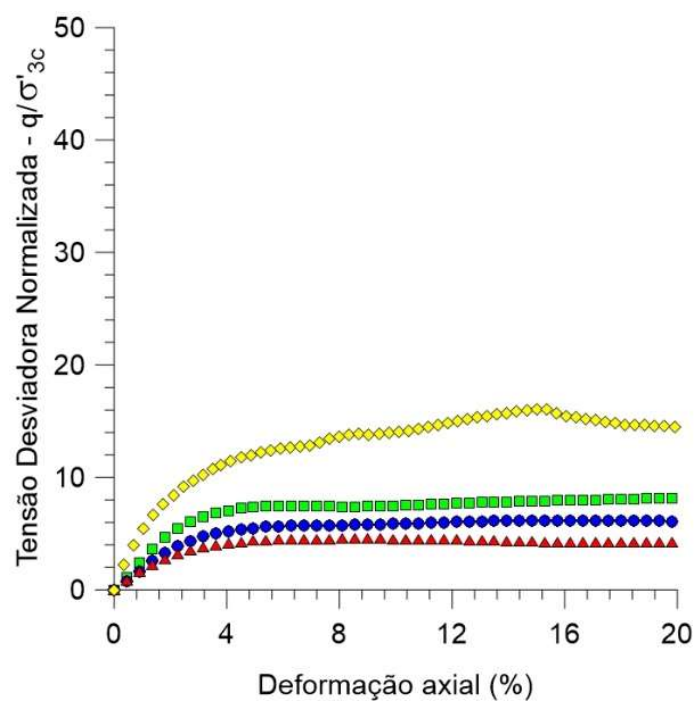

(e)

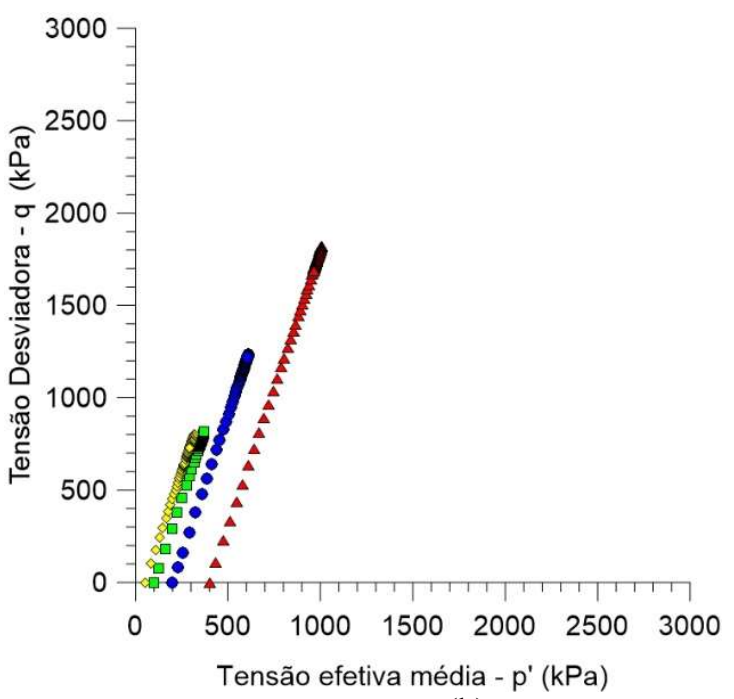

(b)

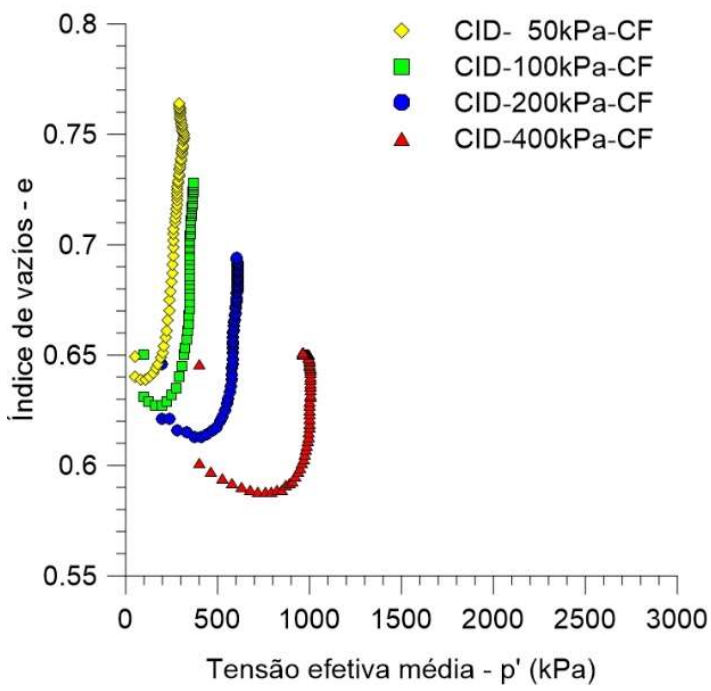

(d)

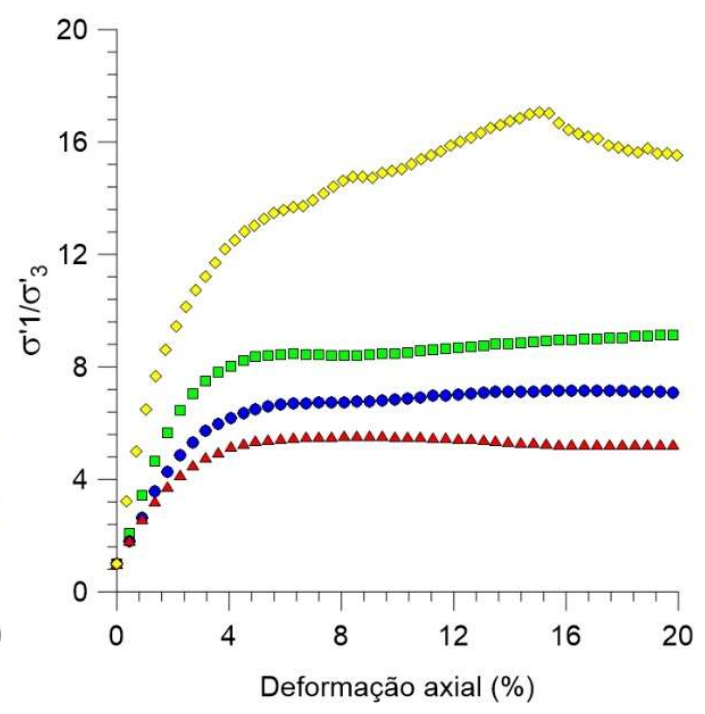

(f)

Figura 5.2. Resultados dos ensaios triaxiais reforçado CD (RMFe) Rejeito de Minério de Ferro 
Nas curvas de índice de vazios vs. tensão efetiva média da Figura 5.1(d), o primeiro ponto corresponde ao índice de vazios antes do adensamento, o segundo, depois do adensamento e os seguintes à variação durante o cisalhamento.

Na Figura 5.1(e) apresenta-se a tensão desviadora normalizada pela tensão efetiva confinante. As curvas mostram que existe certa similaridade de comportamentos entre a tensão média efetiva com exceção da curva de $50 \mathrm{kPa}$ que apresenta uma tensão desviadora normalizada de pico.

No caso do rejeito de minério de ferro reforçado, as curvas tensão desviadora vs. deformação axial da Figura 5.2(a) mostram uma ruptura plástica sem a ocorrência de picos de resistência bem definidos em todas as tensões efetivas de ensaio. No caso reforçado também se mantém o aumento de rigidez correspondente ao acréscimo da tensão efetiva de confinamento. A adição de fibra incrementa significativamente os valores da tensão desviadora comparada com o caso não reforçado. A variação volumétrica da Figura 5.2(c) apresenta uma tendência similar ao caso não reforçado, uma resposta inicial contrativa e depois dilatante, mas com a adição de fibra a resposta dilatante é mais pronunciada do que no caso não reforçado. A não variação do comportamento somente foi atingida na tensão de 400 $\mathrm{kPa}$ em 12\% deformação axial, enquanto as tensões de 50, 100 e $200 \mathrm{kPa}$ continuam incrementando a tendência dilatante.

As curvas de índice de vazios vs. tensão efetiva média da Figura 5.2(d) apresentam similaridade no comportamento. O índice de vazios antes do adensamento é menor do que no caso não reforçado pela presença das fibras que ocupam parte dos espaços vazios. Note-se que, durante o cisalhamento, a variação do índice de vazios reforçado é maior do que não reforçado, mostrando que a fibra influi no arranjo natural dos grãos. A Figura 5.2(e) exibe que todas as tensões mostram similaridade no comportamento normalizado do rejeito de minério de ferro reforçado.

\subsubsection{2.}

\section{Ensaio triaxial não drenado (CU)}

Neste item são apresentados os resultados dos ensaios triaxiais não drenados realizados no rejeito de minério de ferro não reforçado e reforçado.

Na Tabela 5.2, são apresentados os dados de teor de umidade, peso específico, índice de vazios, porosidade e saturação inicial seguidos do índice de vazios após o 
adensamento e no final do ensaio, junto com o teor de umidade final. Nas Figuras 5.3 e 5.4, apresentam-se os gráficos correspondentes aos ensaios não drenados: (a)

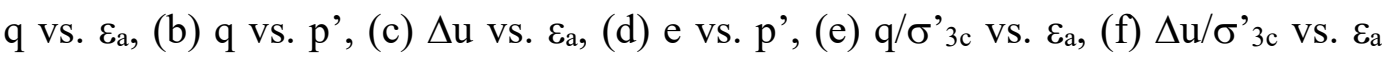
onde: deformação axial $=\varepsilon_{\mathrm{a}}$, excesso de poropressão $=\Delta \mathrm{u}$, índice de vazios $=\mathrm{e}$, tensão efetiva média $p^{\prime}=\left(\left(\sigma^{\prime}{ }_{1}+2 \sigma^{\prime}{ }_{3}\right) / 3\right)$, tensão desviadora $q=\left(\sigma^{\prime}{ }_{1}-\sigma^{\prime}{ }_{3}\right)$ e tensão efetiva de confinamento $=\sigma^{\prime} 3 \mathrm{c}$.

Tabela 5.2. Variação dos índices físicos CU (RMFe)

Rejeito de Minério de Ferro

\begin{tabular}{|c|c|c|c|c|c|c|c|c|c|c|}
\hline \multirow{2}{*}{ Ensaio } & \multirow{2}{*}{$\begin{array}{l}\sigma^{\prime}{ }_{3} \\
\mathrm{kPa}\end{array}$} & \multicolumn{6}{|c|}{$\begin{array}{c}\text { Índices físicos } \\
\text { Iniciais } \\
\end{array}$} & \multirow{2}{*}{$\begin{array}{c}\begin{array}{c}\text { Após o } \\
\text { adensamento }\end{array} \\
\mathrm{e}_{\text {adens. }}\end{array}$} & \multicolumn{2}{|c|}{$\begin{array}{c}\text { Índices Físicos } \\
\text { Finais } \\
\end{array}$} \\
\hline & & $\begin{array}{l}\mathrm{W}_{\mathrm{o}} \\
\%\end{array}$ & $\begin{array}{c}\gamma_{\mathrm{n}} \\
\mathrm{kN} / \mathrm{m}^{3}\end{array}$ & $\begin{array}{c}\gamma_{\mathrm{d}} \\
\mathrm{kN} / \mathrm{m}^{3}\end{array}$ & $\mathrm{e}_{\mathrm{o}}$ & $\begin{array}{l}\mathrm{n} \\
\%\end{array}$ & $\begin{array}{l}\mathrm{S} \\
\%\end{array}$ & & $e_{f}$ & $\begin{array}{l}\mathrm{W}_{\mathrm{f}} \\
\%\end{array}$ \\
\hline Fe-CIU- 50-sf & 50 & 12,28 & 19,70 & 17,35 & 0,652 & 39,46 & 55,20 & 0,637 & 0,637 & 22,77 \\
\hline Fe-CIU-100-sf & 100 & 12,96 & 19,60 & 17,35 & 0,663 & 39,76 & 56,40 & 0,640 & 0,640 & 21,36 \\
\hline Fe-CIU-200-sf & 200 & 12,46 & 19,65 & 17,48 & 0,655 & 39,58 & 55,03 & 0,633 & 0,633 & 22,66 \\
\hline Fe-CIU-400-sf & 400 & 12,90 & 19,66 & 17,41 & 0,661 & 39,79 & 56,47 & 0,633 & 0,633 & 22,48 \\
\hline Fe-CIU- 50-cf & 50 & 12,41 & 19,67 & 17,49 & 0,653 & 39,52 & 54,95 & 0,646 & 0,646 & 22,39 \\
\hline Fe-CIU-100-cf & 100 & 12,64 & 19,75 & 17,53 & 0,650 & 39,21 & 56,26 & 0,637 & 0,637 & 22,17 \\
\hline Fe-CIU-200-cf & 200 & 12,67 & 19,76 & 17,54 & 0,649 & 39,14 & 56,42 & 0,625 & 0,625 & 22,80 \\
\hline Fe-CIU-400-cf & 400 & 12,72 & 19,76 & 17,53 & 0,650 & 39,22 & 56,62 & 0,616 & 0,616 & 22,71 \\
\hline
\end{tabular}

A Figura 5.3(a) mostra um comportamento similar em todos os ensaios com tensões cisalhantes máximas entre 2 e $5 \%$ passando lentamente a apresentar um comportamento de strain hardening a partir de 6\% de deformação axial. Na Figura 5.3(b), os corpos de prova mostram uma trajetória direcionada para a direita sendo mais perceptível em tensões altas desde o início da compressão e mudam a inclinação ao atingir a envoltória de ruptura. As poropressões crescem até $2 \%$ de deformação axial mostrando um comportamento contrativo que depois é reduzido drasticamente pela inerente tendência dilatante do rejeito, de acordo com o que é mostrado nos ensaios CD na Figura 5.1(c). Essa redução é menor quanto mais alto é o nível de tensão efetiva de confinamento como mostra a Figura 5.3(c). A Figura 5.3(d) mostra que o índice de vazios dos ensaios triaxiais CU não possuem variação alguma verificando as características não drenadas do ensaio. Na Figura 5.3(e), o comportamento não drenado apresenta uma maior tensão desviadora normalizada do que no caso drenado tal comportamento seria produto da diminuição da poropressão. A Figura 5.3(f) mostra a variação do excesso de poropressão normalizada pela tensão efetiva de confinamento, nota-se que o efeito de poropressão é suprimido em altas tensões efetivas. 


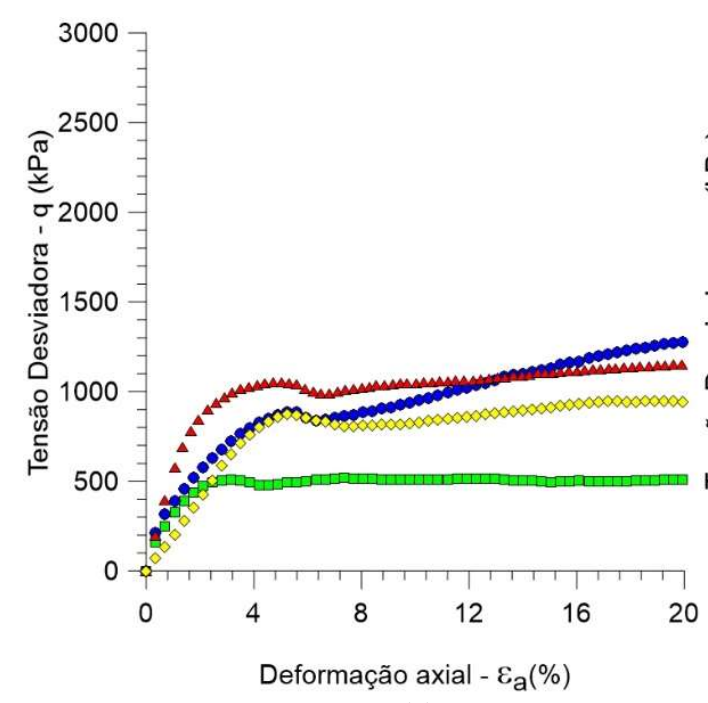

(a)

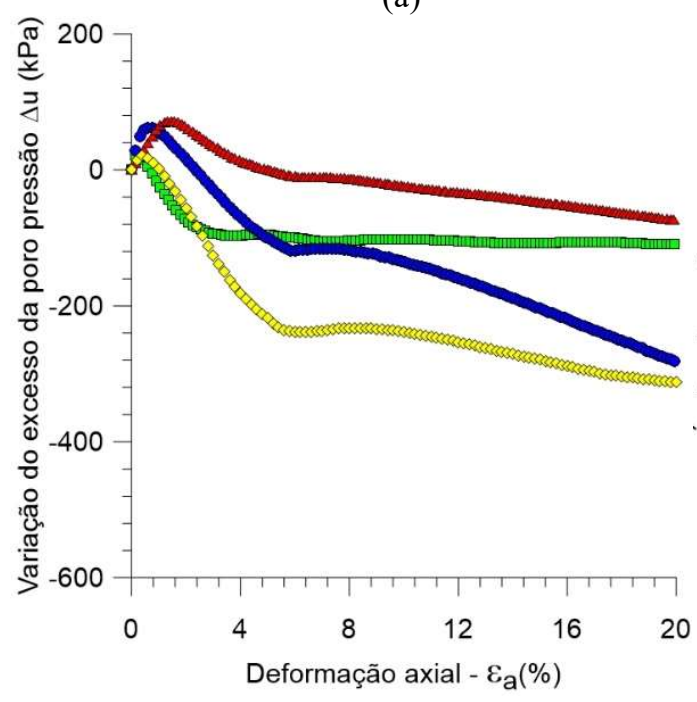

(c)

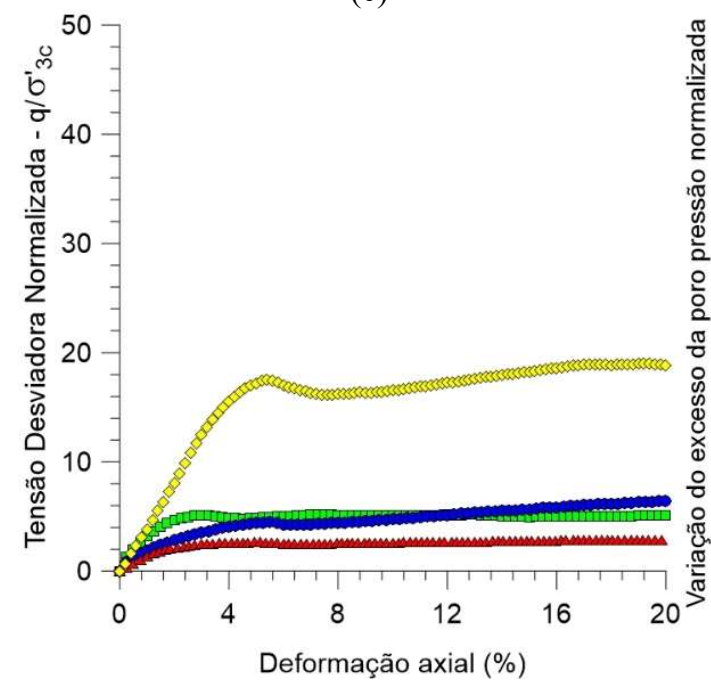

(e)

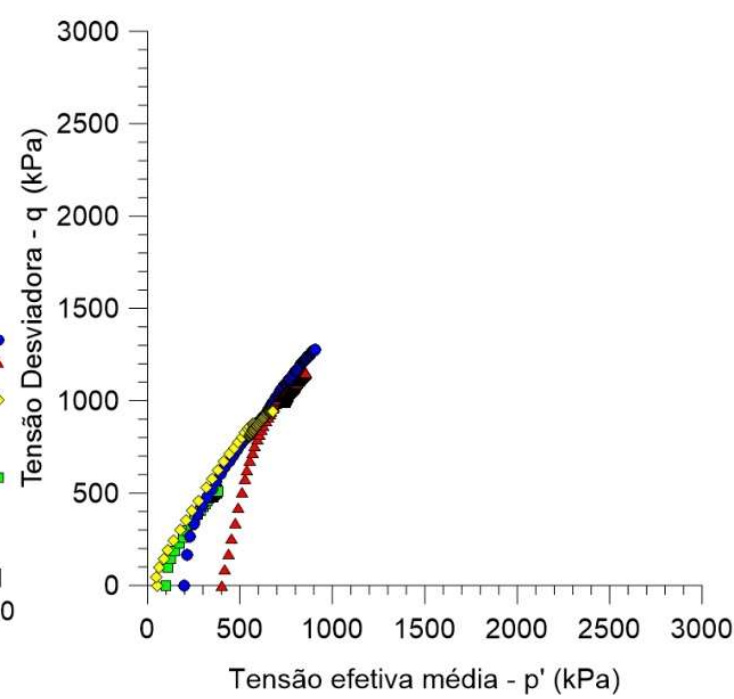

(b)

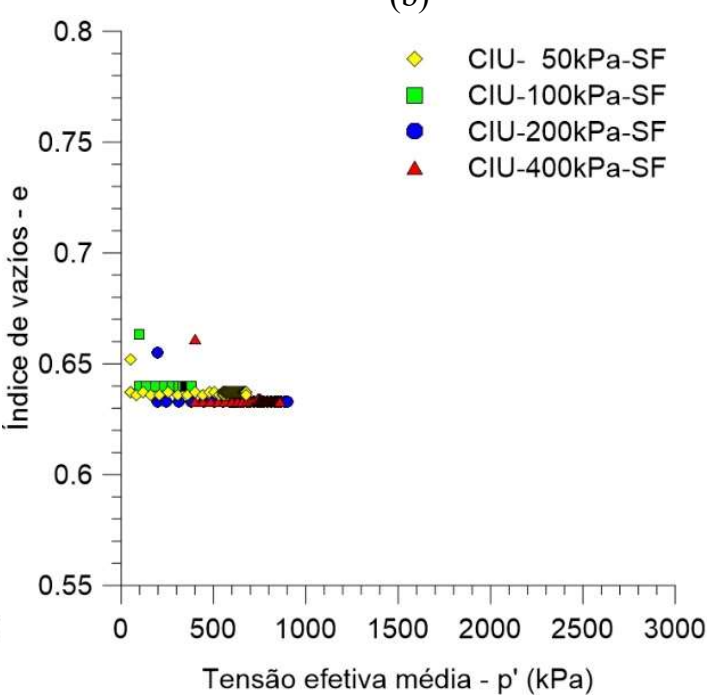

(d)

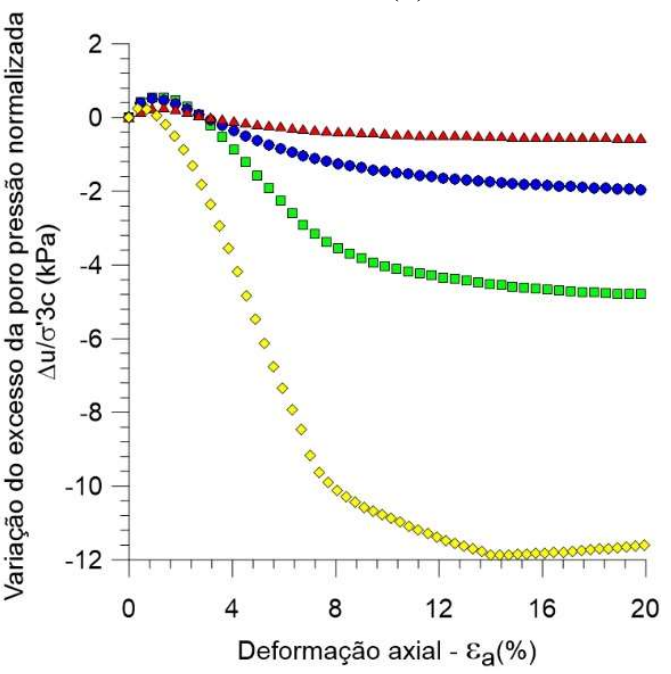

(f)

Figura 5.3. Resultados dos ensaios triaxiais não reforçado CU (RMFe)

Rejeito de Minério de Ferro 


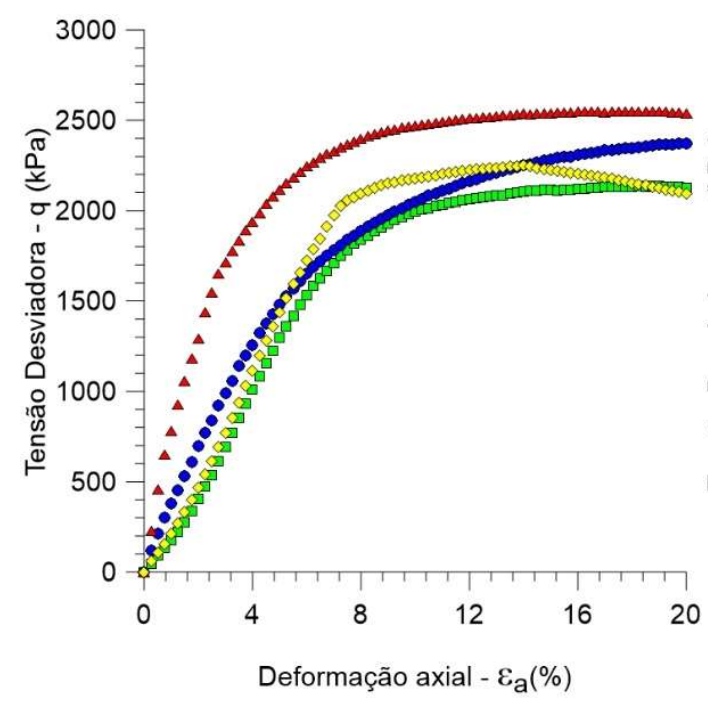

(a)

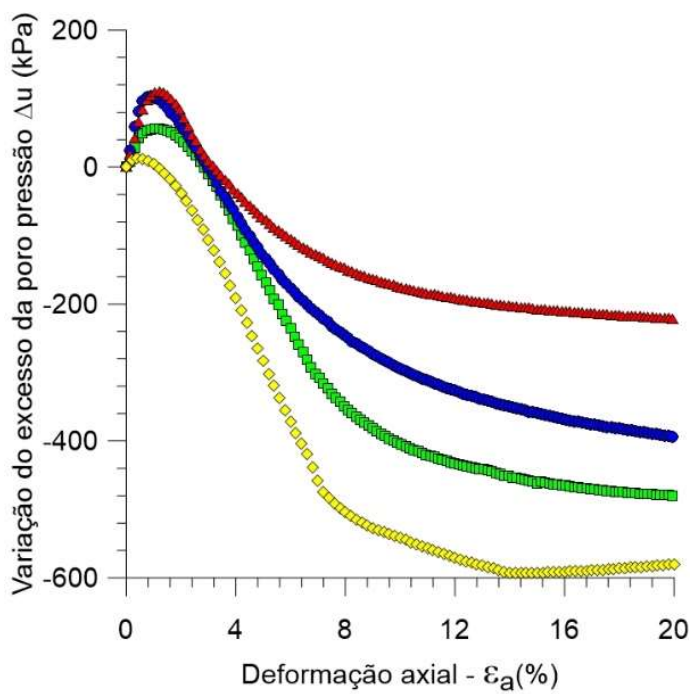

(c)

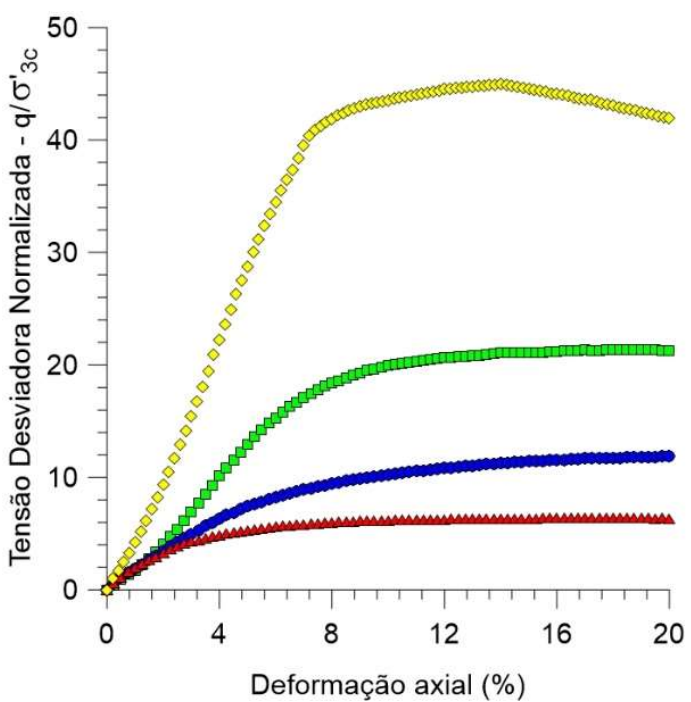

(e)

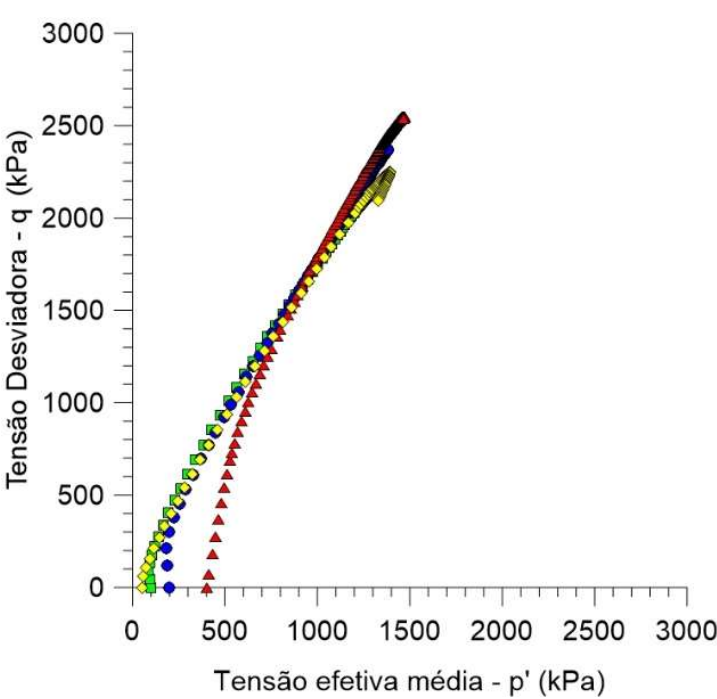

(b)

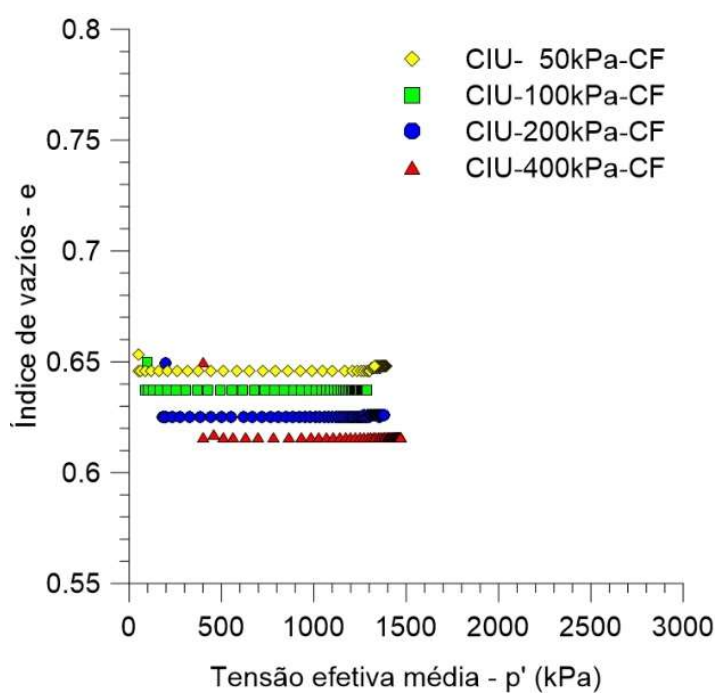

(d)

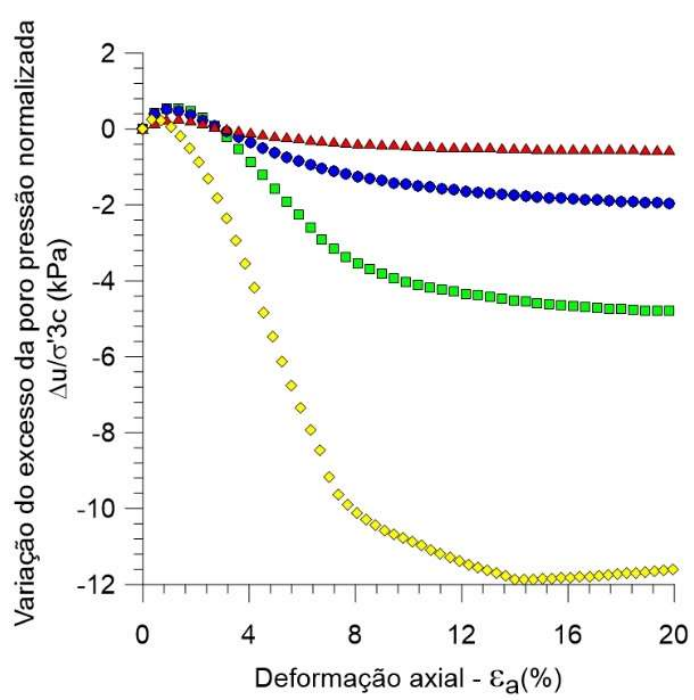

(f)

Figura 5.4. Resultados dos ensaios triaxiais reforçado CU (RMFe) Rejeito de Minério de Ferro 
No caso reforçado, na Figura 5.4(a) nota-se que a tensão cisalhante atinge um valor máximo entre 8 e $12 \%$ se mantendo estável e apresentando maior ductilidade do que no caso não reforçado.

As trajetórias de tensão da Figura 5.4(b), similar ao caso não reforçado, também mostram uma trajetória direcionada à direita no espaço p'-q até chegar à envoltória de ruptura.

A Figura 5.4(c) mostra que existe uma queda maior da variação do excesso de poropressão do que no caso não reforçado. Inicialmente o rejeito reforçado consegue um maior acréscimo de poropressão, mas a queda é maior do que no caso não reforçado. Na Figura 5.4(d) também se verificam as características não drenadas do ensaio.

A Figura 5.4 (e) mostra, em geral, um comportamento similar entre as tensões desviadoras normalizadas, mostrando uma fase de crescimento e estabilização. $\mathrm{Na}$ tensão efetiva de $50 \mathrm{kPa}$ é possível observar que a tensão desviadora normalizada sofre uma queda após atingir o máximo pela supressão da queda de poropressão que se nota na Figura 5.4(c) a partir de uma deformação axial de 14\%.

A Figura 5.4(f) mostra uma maior queda da variação do excesso de poropressão normalizada em tensões baixas, para uma tensão de $400 \mathrm{kPa}$ não existe uma variação importante comparado com o caso não reforçado.

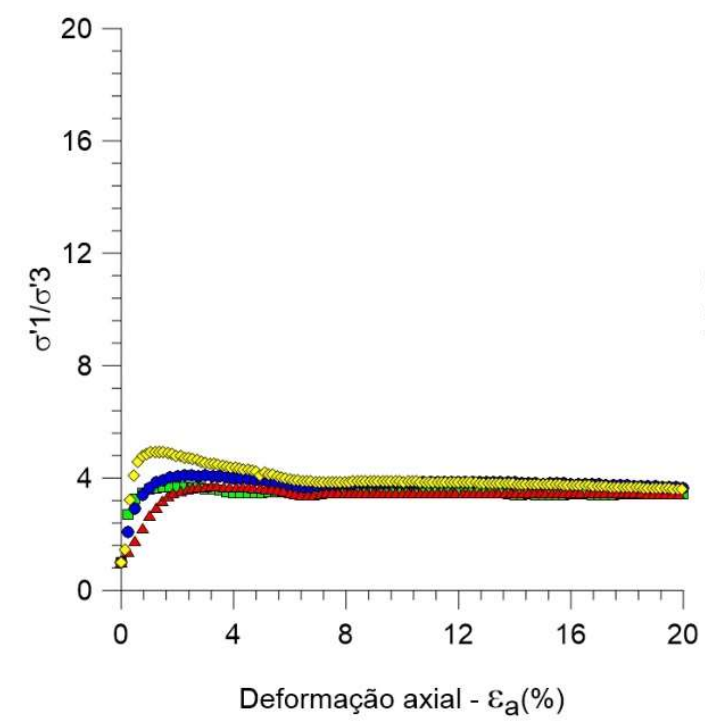

(a)

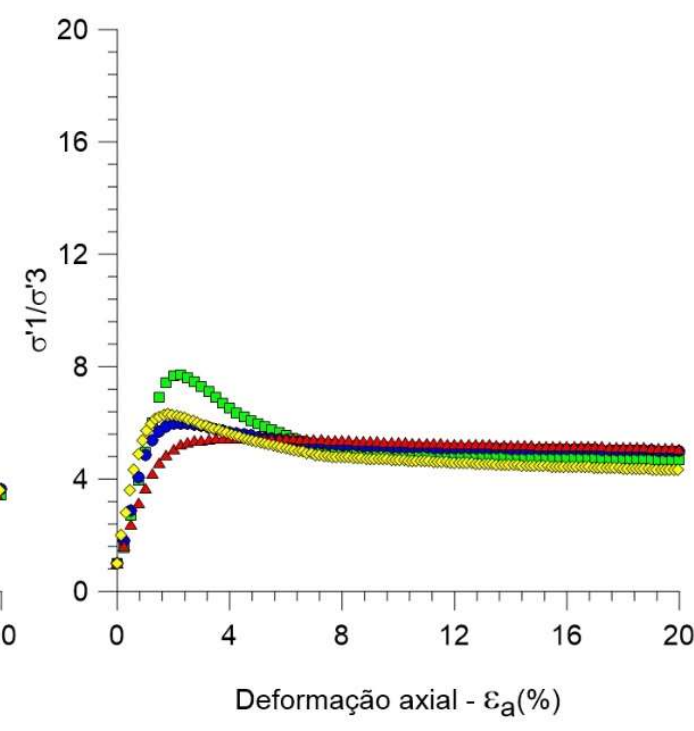

(b)

Figura 5.5. Razão de tensões principais efetivas vs. deformação axial (RMFe) Rejeito de Minério de Ferro (a) não reforçado (b) reforçado34653051170 
As Figuras 5.5(a) e (b), mostram a razão de tensões efetivas principais para o caso não reforçado e reforçado, respectivamente. Como existe um comportamento plástico nos ensaios não drenados, os pontos utilizados para determinar a envoltória e resistências correspondem ao valor de pico $\left(\sigma^{\prime}{ }_{1} / \sigma^{\prime}{ }_{3}\right)_{\text {máx }}$ destas curvas.

\subsection{2.}

\section{Rejeito de Minério de Ouro (RMAu)}

\subsubsection{1.}

\section{Ensaio triaxial drenado (CD)}

Neste item são apresentados os resultados dos ensaios triaxiais drenados realizados no rejeito de minério de ouro não reforçado e reforçado.

$\mathrm{Na}$ Tabela 5.3, se apresentam os dados de teor de umidade, peso especifico, índice de vazios, porosidade e saturação inicial seguidos do índice de vazios após o adensamento e no final do ensaio, junto com o teor de umidade final.

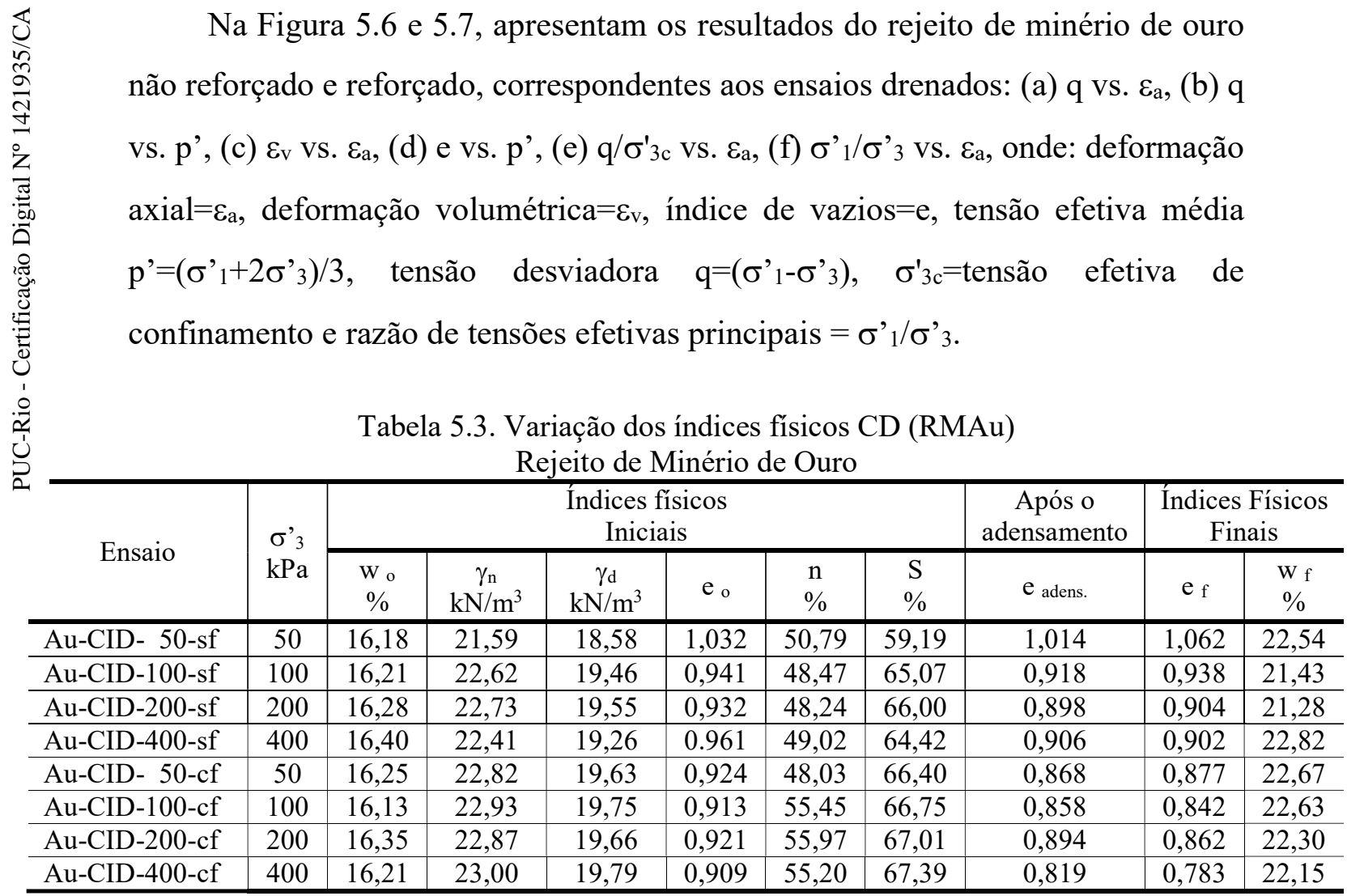

No rejeito de minério de ouro não reforçado, as curvas tensão desviadora vs. deformação axial na Figura 5.6(a) apresentam uma ruptura frágil com ocorrência de pico de resistência claro na tensão de $400 \mathrm{kPa}$, enquanto para tensões menores 
os picos existem mas não são bem definidos, os resultados mostram um aumento de rigidez com o aumento da tensão efetiva de confinamento.

As deformações volumétricas na Figura 5.6(c) mostraram uma tendência inicial à compressão que passa a ser de dilatância sendo que em tensões menores (50 $\mathrm{kPa}$ em 1,5\% e $100 \mathrm{kPa}$ em 3,5\%) mudaram a tendência de contrativa para dilatante mais rápido do que as maiores (200 kPa em 4,0\% e $400 \mathrm{kPa}$ em 6\%). A tendência de dilatância permaneceu até o $20 \%$ de deformação axial, em todos os níveis de tensão efetiva de confinamento. Nas curvas de índice de vazios vs. tensão efetiva média da Figura 5.6(d), observam-se que, no final do ensaio, o índice de vazios aumenta conforme à tendência dilatante.

$\mathrm{Na}$ Figura 6(e) apresenta-se a tensão desviadora normalizada pela tensão efetiva confinante. As curvas mostram que existe similaridade no comportamento com exceção da curva de $50 \mathrm{kPa}$ que apresenta uma tensão desviadora de pico normalizada.

No rejeito de minério de ouro reforçado, as curvas tensão desviadora vs. deformação axial na Figura 5.7(a), apresentam uma ruptura plástica sem ocorrência de picos e com um aumento continuo da resistência até o $20 \%$ de deformação axial, os resultados também mostram um aumento de rigidez com o aumento da tensão efetiva de confinamento.

A adição de fibra incrementa a resistência ao cisalhamento em todos os níveis de tensão efetiva de confinamento. A contribuição da fibra é maior em tensões efetivas de confinamento menores como se mostra na Figura 5.7(e).

As deformações volumétricas na Figura 5.7(c) mostraram uma tendência inicial à compressão que é suprimida onde em tensões menores (50 kPa em 2,2\% e $100 \mathrm{kPa}$ em 7,0\%) suprimiram a tendência contrativa mais rápido do que as maiores (200 kPa em 8,9\% e $400 \mathrm{kPa}$ em 9,0\%). A tendência contrativa permaneceu até o $20 \%$ de deformação em todos os níveis de tensão efetiva de confinamento.

Nas curvas de índice de vazios vs. tensão efetiva média da Figura 5.7(d) observa-se que, conforme incrementa a tensão efetiva média, o índice de vazios diminui.

Na Figura 5.7(e) apresenta-se a tensão desviadora normalizada pela tensão efetiva confinante. As curvas mostram que existe similaridade no comportamento para todos os níveis de tensão. 


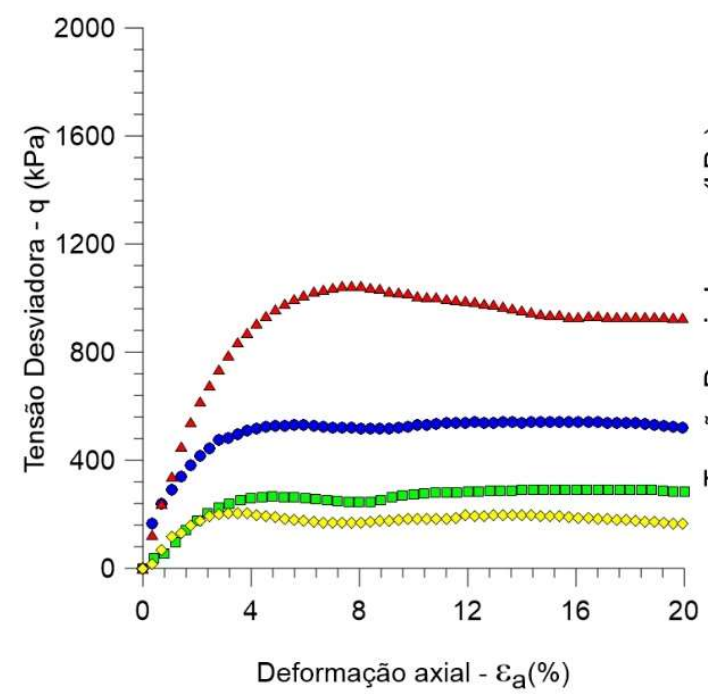

(a)

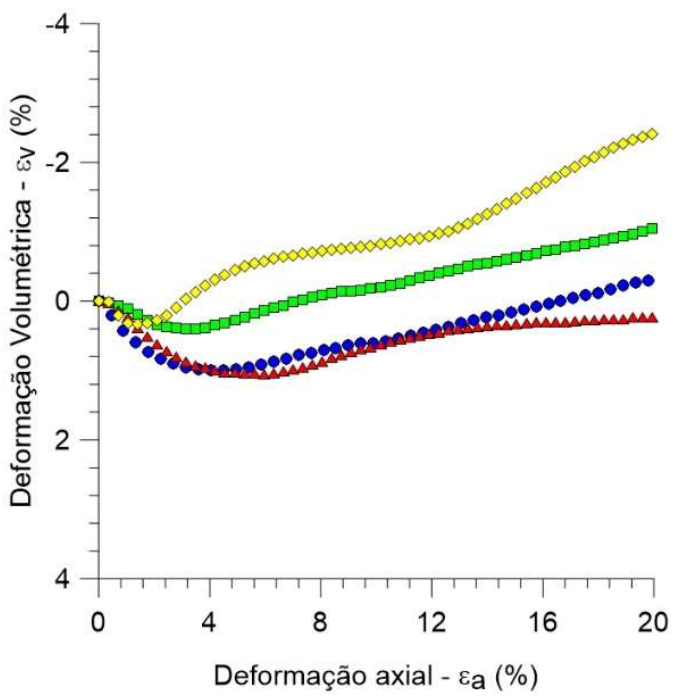

(c)

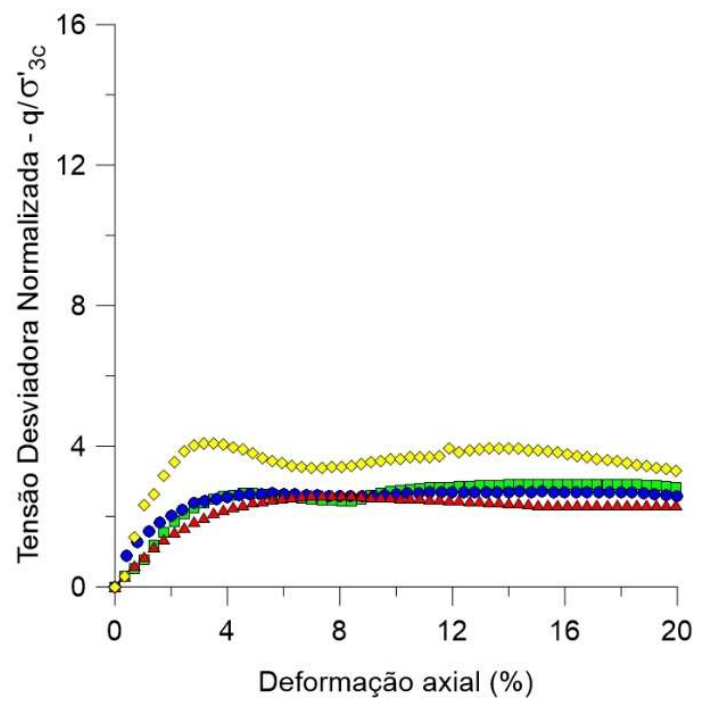

(e)

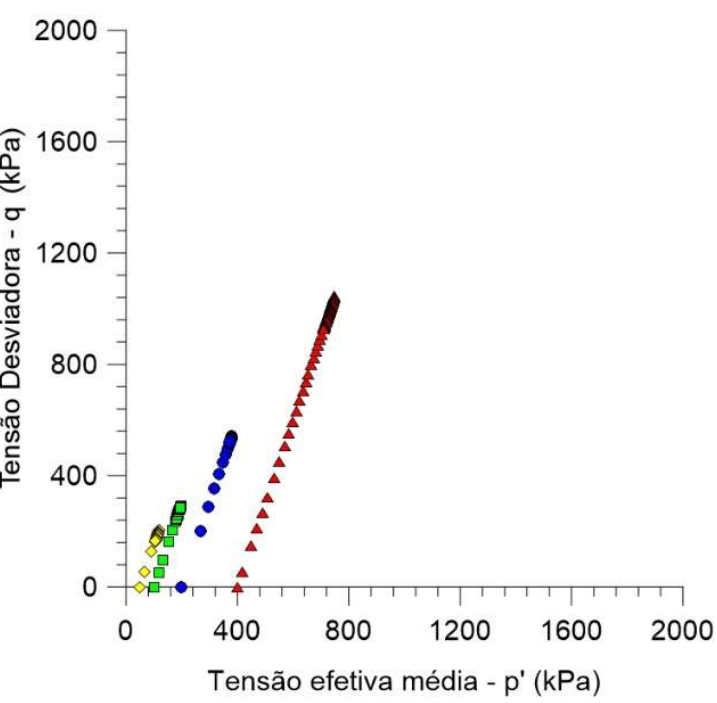

(b)

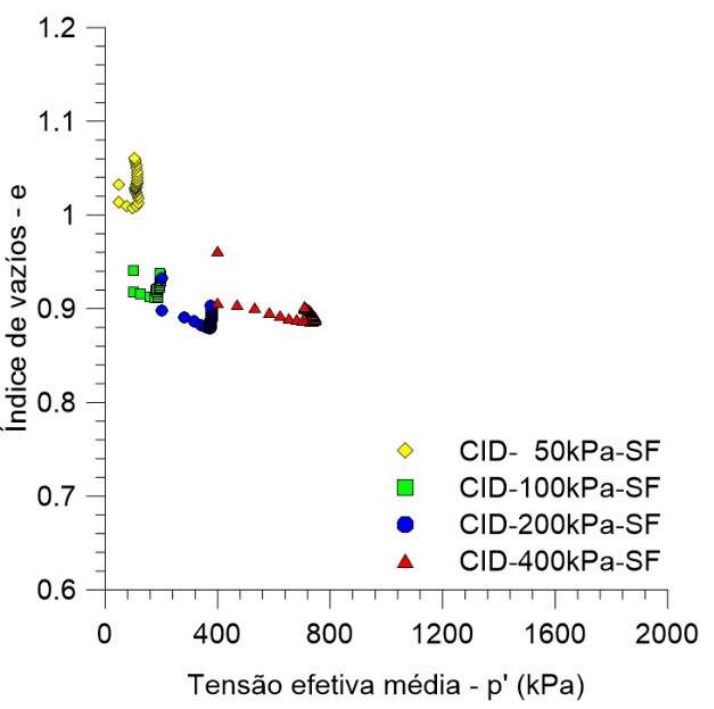

(d)

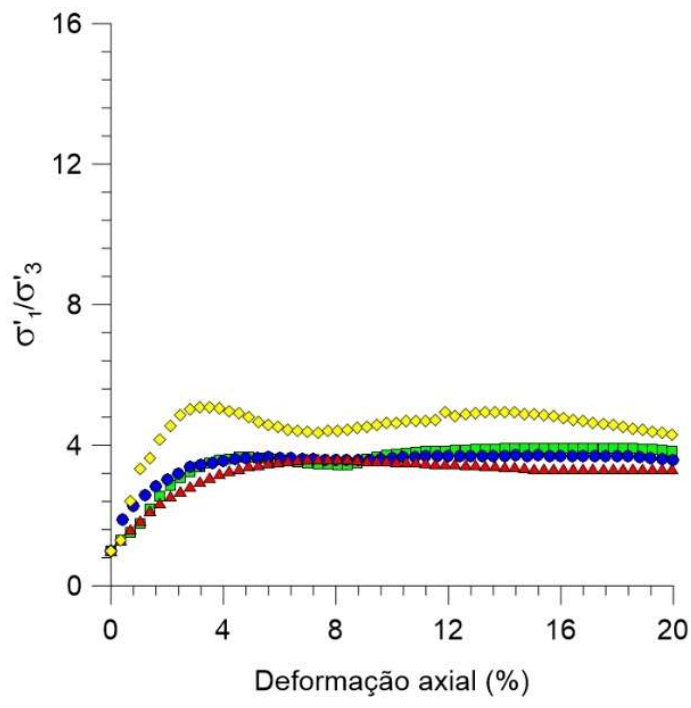

(f)

Figura 5.6. Resultados dos ensaios triaxiais não reforçado CD (RMAu)

Rejeito de Minério de Ouro 


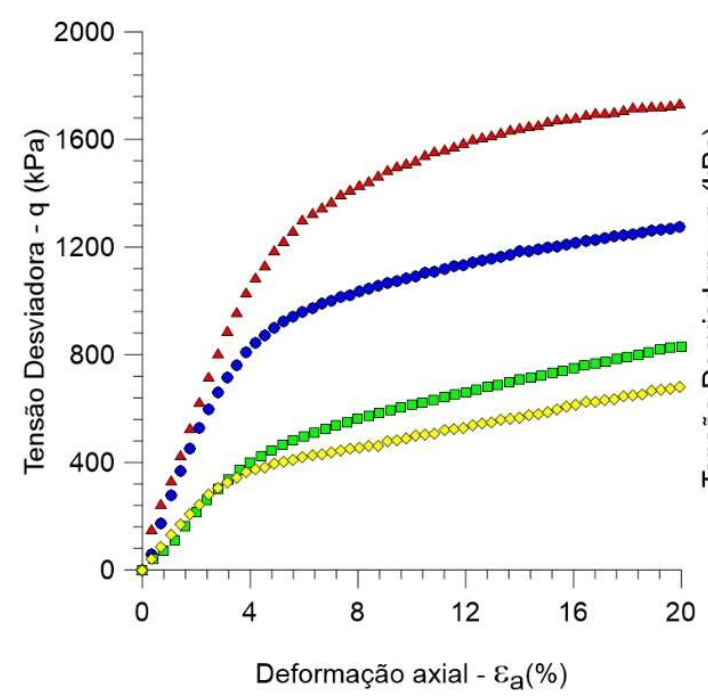

(a)

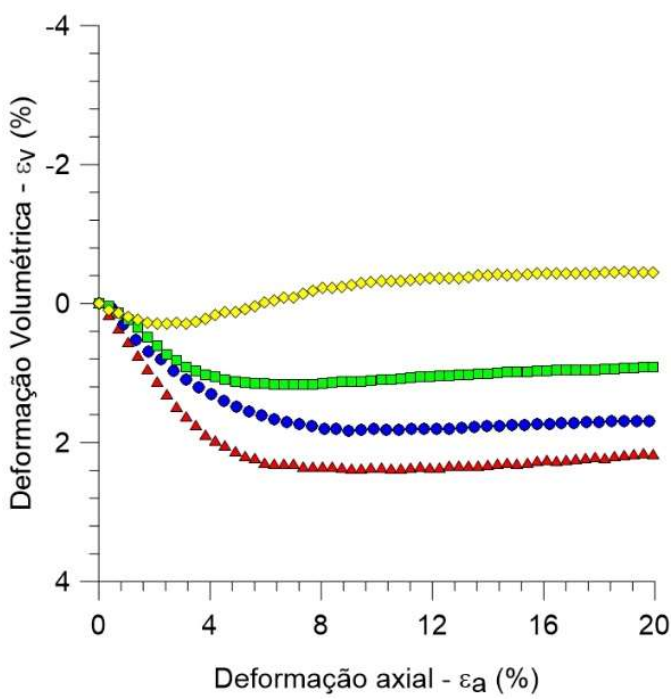

(c)

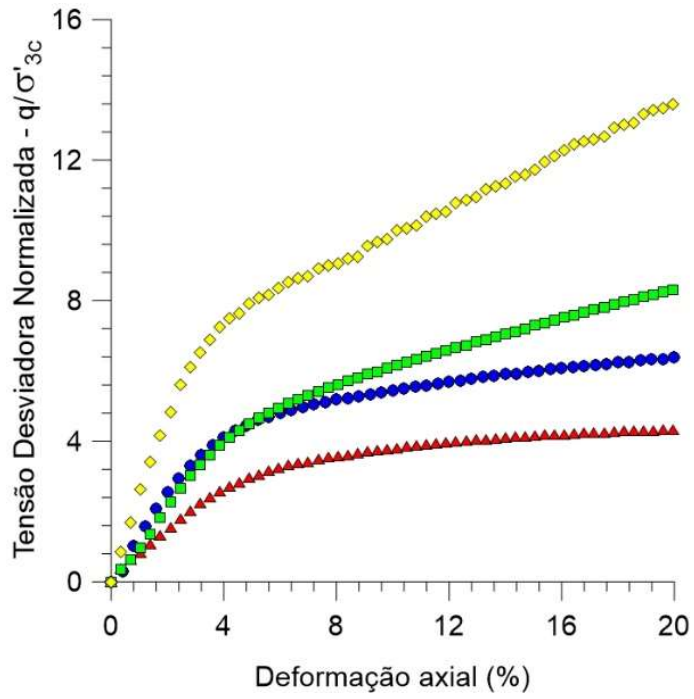

(e)

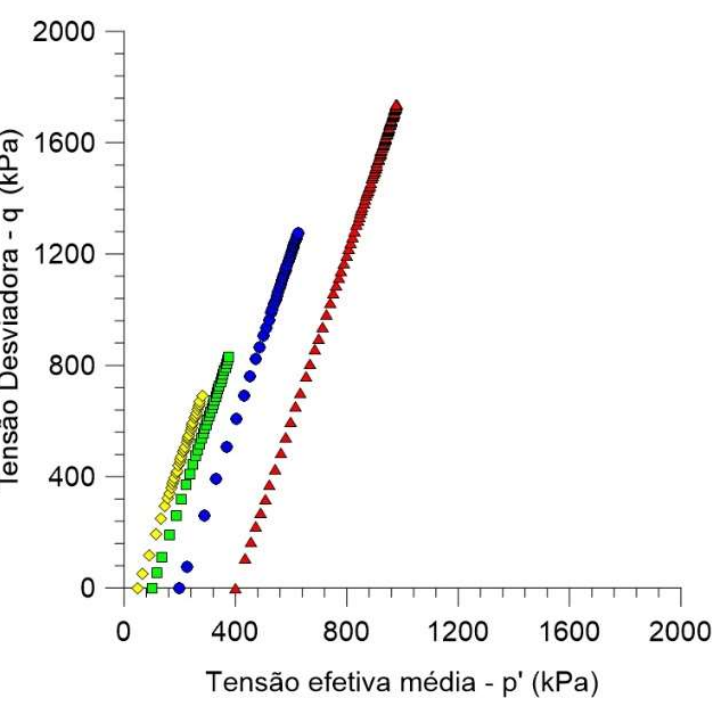

(b)

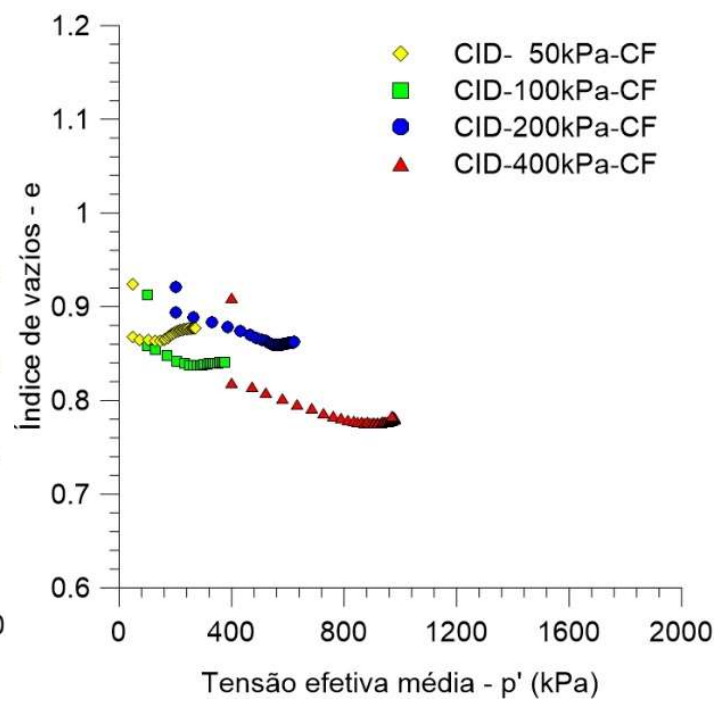

(d)

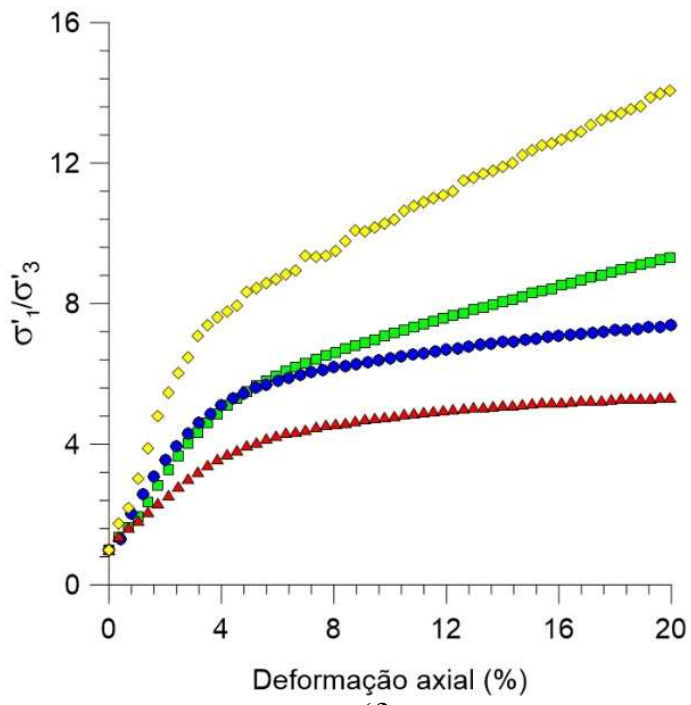

(f)

Figura 5.7. Resultados dos ensaios triaxiais reforçado CD (RMAu)

Rejeito de Minério de Ouro 


\subsubsection{2. \\ Ensaio triaxial não drenado (CU)}

Neste item são apresentados os resultados dos ensaios triaxiais não drenados realizados no rejeito de minério de ouro não reforçado e reforçado.

$\mathrm{Na}$ Tabela 5.4, se apresentam os dados de teor de umidade, peso específico, índice de vazios, porosidade e saturação inicial seguidos do índice de vazios após o adensamento e no final do ensaio, junto com o teor de umidade final. Nas Figuras 5.8 e 5.9, apresentam-se os gráficos correspondentes aos ensaios não drenados: (a)

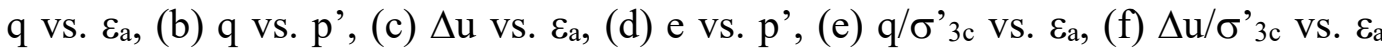
onde: deformação axial $=\varepsilon_{\mathrm{a}}$, excesso de poropressão $=\Delta \mathrm{u}$, índice de vazios $=\mathrm{e}$, tensão efetiva média $p^{\prime}=\left(\sigma^{\prime}{ }_{1}+2 \sigma^{\prime}{ }_{3}\right) / 3$, tensão desviadora $q=\left(\sigma^{\prime}{ }_{1}-\sigma^{\prime}{ }_{3}\right)$ e tensão efetiva de confinamento $=\sigma^{\prime} 3 \mathrm{c}$.

Tabela 5.4. Variação dos índices físicos CU (RMAu) Rejeito de Minério de Ouro

\begin{tabular}{|c|c|c|c|c|c|c|c|c|c|c|}
\hline \multirow{2}{*}{ Ensaio } & \multirow{2}{*}{$\begin{array}{c}\sigma_{3}^{\prime} \\
\mathrm{kPa}\end{array}$} & \multicolumn{6}{|c|}{$\begin{array}{c}\text { Índices físicos } \\
\text { Iniciais } \\
\end{array}$} & \multirow{2}{*}{$\begin{array}{c}\begin{array}{c}\text { Após o } \\
\text { adensamento }\end{array} \\
\mathrm{e}_{\text {adens. }}\end{array}$} & \multicolumn{2}{|c|}{$\begin{array}{c}\text { Índices Físicos } \\
\text { Finais }\end{array}$} \\
\hline & & $\begin{array}{c}\mathrm{W}_{\mathrm{o}} \\
\%\end{array}$ & $\begin{array}{c}\gamma_{\mathrm{n}} \\
\mathrm{kN} / \mathrm{m}^{3}\end{array}$ & $\begin{array}{c}\gamma_{\mathrm{d}} \\
\mathrm{kN} / \mathrm{m}^{3}\end{array}$ & $\mathrm{e}_{\mathrm{o}}$ & $\begin{array}{l}\mathrm{n} \\
\%\end{array}$ & $\begin{array}{l}\mathrm{S} \\
\%\end{array}$ & & $\mathrm{e}_{\mathrm{f}}$ & $\begin{array}{l}\mathrm{W}_{\mathrm{f}} \\
\%\end{array}$ \\
\hline 4u-CIU- 50-sf & 50 & 16,10 & 21,51 & 18,53 & 1,038 & 50,94 & 58,57 & 1,022 & 1,022 & 22,24 \\
\hline 4u-CIU-100-sf & 100 & 16,40 & 22,80 & 19,59 & 0,928 & 48,14 & 66,74 & 0,912 & 0,912 & 21,65 \\
\hline 4u-CIU-200-sf & 200 & 16,74 & 22,60 & 19,36 & 0,951 & 48,75 & 66,45 & 0,884 & 0,884 & 22,25 \\
\hline 4u-CIU-400-sf & 400 & 16,40 & 23,82 & 20,47 & 0,846 & 45,81 & 73,25 & 0,784 & 0,784 & 21,83 \\
\hline 4u-CIU- 50-cf & 50 & 16,38 & 25,63 & 22,02 & 0,715 & 41,69 & 86,53 & 0,686 & 0,686 & 22,37 \\
\hline Au-CIU-100-cf & 100 & 16,40 & 23,86 & 20,50 & 0,842 & 45,72 & 73,53 & 0,787 & 0,787 & 22,22 \\
\hline 4u-CIU-200-cf & 200 & 16,23 & 24,82 & 21,35 & 0,769 & 43,46 & 79,72 & 0,695 & 0,695 & 21,93 \\
\hline 4u-CIU-400-cf & 400 & 16,19 & 23,31 & 20,06 & 0,883 & 46,89 & 69,26 & 0,754 & 0,754 & 22,27 \\
\hline
\end{tabular}

Nos rejeitos de minério de ouro não reforçado, a Figura 5.8(a) mostra que as curvas têm um rápido incremento da tensão desviadora entre 1-2\% de deformação axial seguidas de um incremento lento e constante até o final do ensaio, sendo este comportamento similar em todos os casos.

$\mathrm{Na}$ Figura 5.8(b), as trajetórias de tensão do material adensado para as tensões efetivas de $50 \mathrm{kPa}$ e $400 \mathrm{kPa}$ seguem uma direção quase vertical inclinando-se para a direita ao atingir a envoltória de ruptura.

Os corpos de prova adensados nas tensões de $100 \mathrm{kPa}$ e $200 \mathrm{kPa}$ apresentam uma trajetória direcionada para a esquerda desde o início da compressão, inclinando-se para a direita também ao atingir a envoltória de ruptura. 


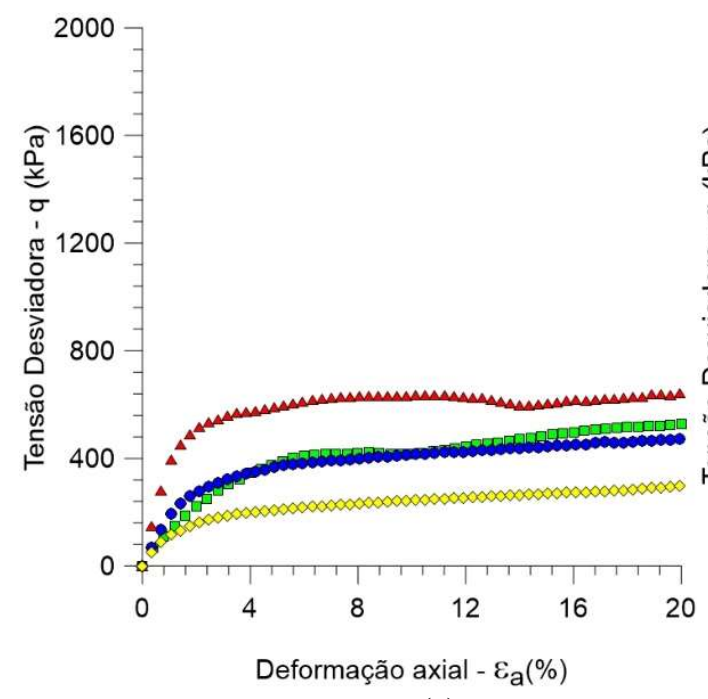

(a)

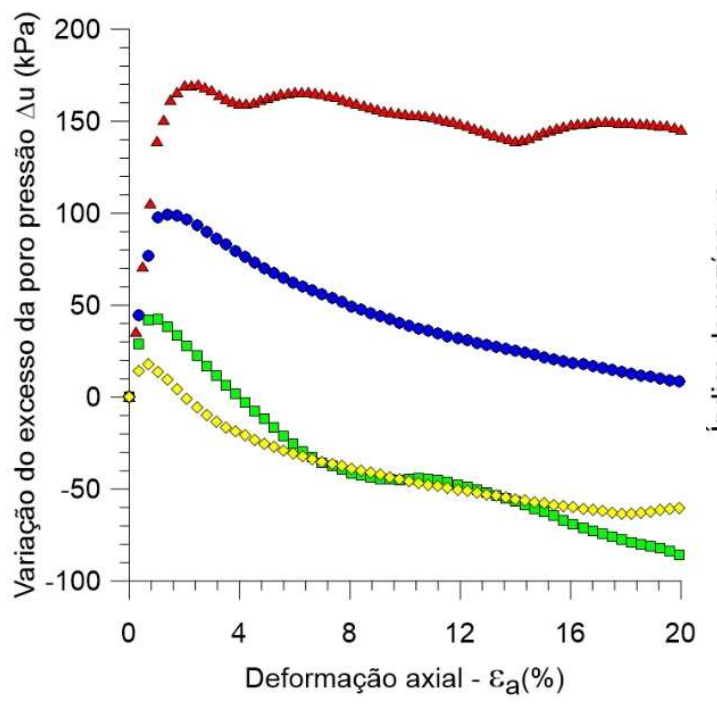

(c)

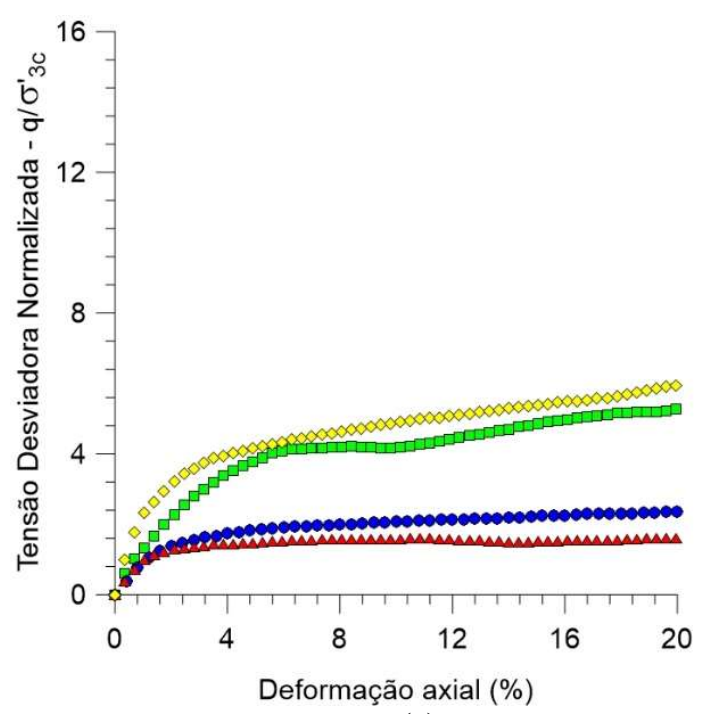

(e)

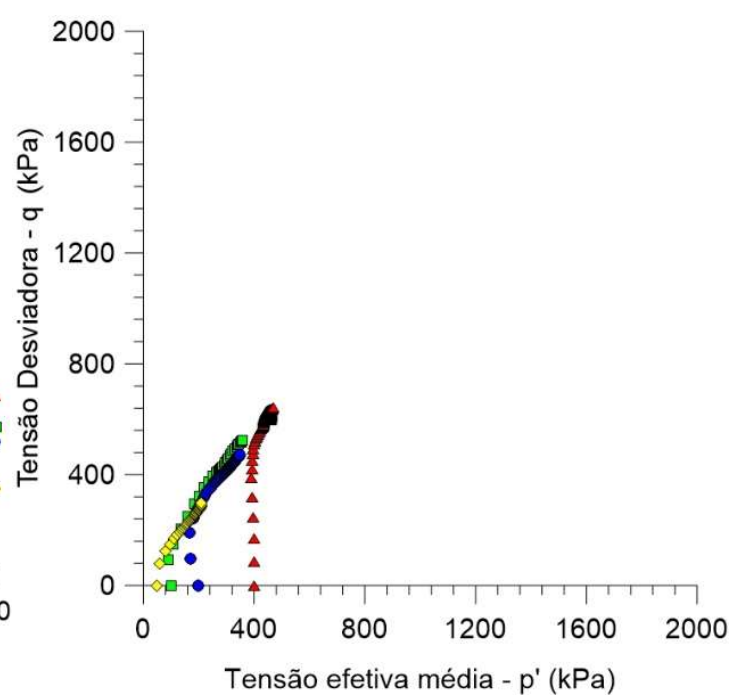

(b)

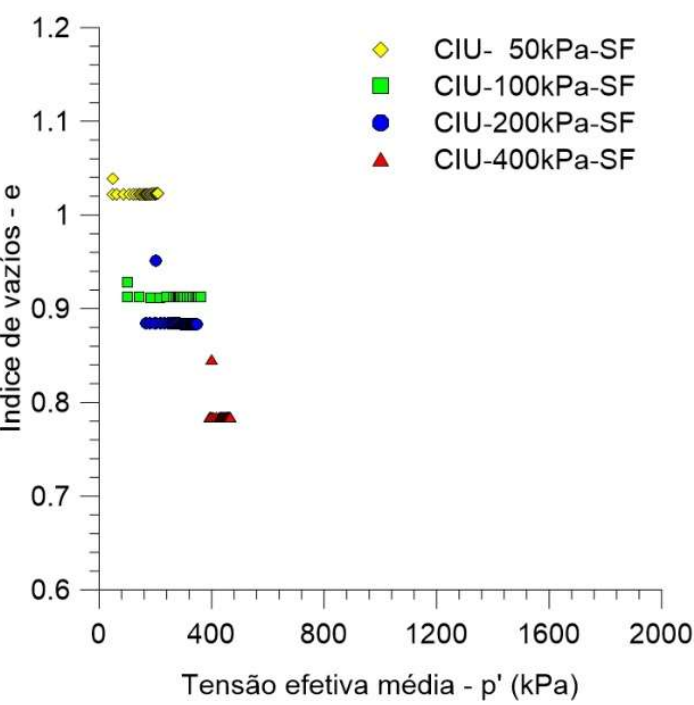

(d)

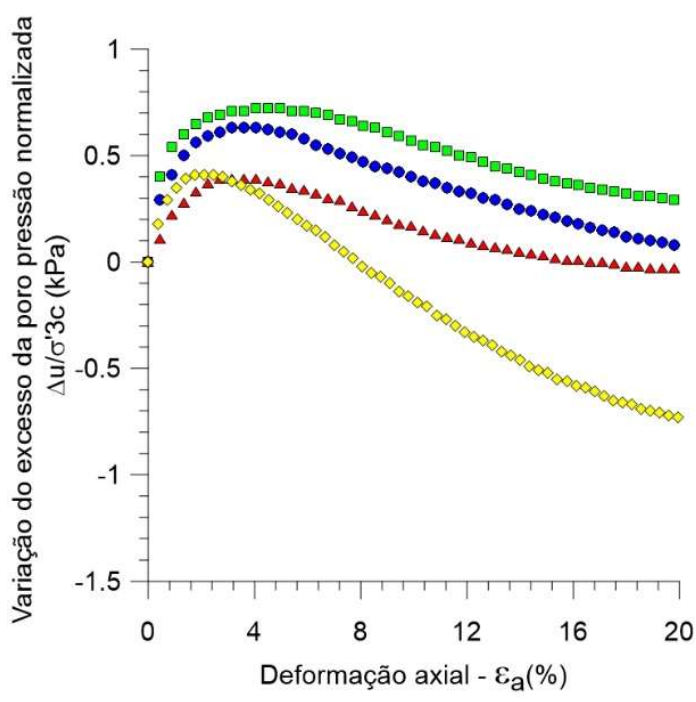

(f)

Figura 5.8. Resultados dos ensaios triaxiais não reforçado CU (RMAu)

Rejeito de Minério de Ouro 


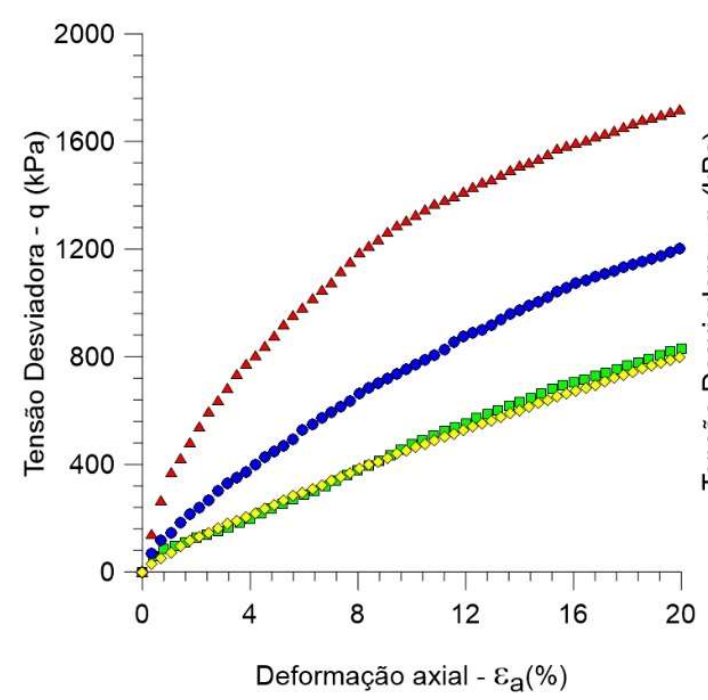

(a)

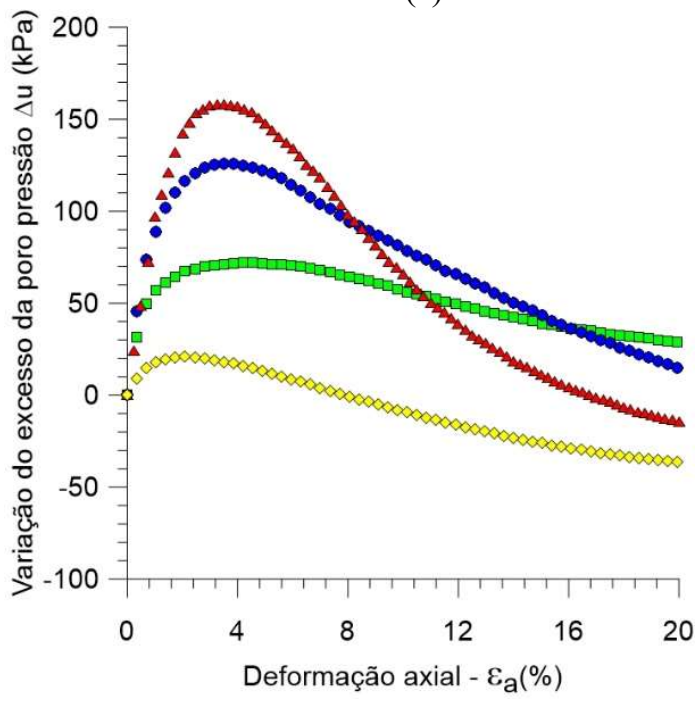

(c)

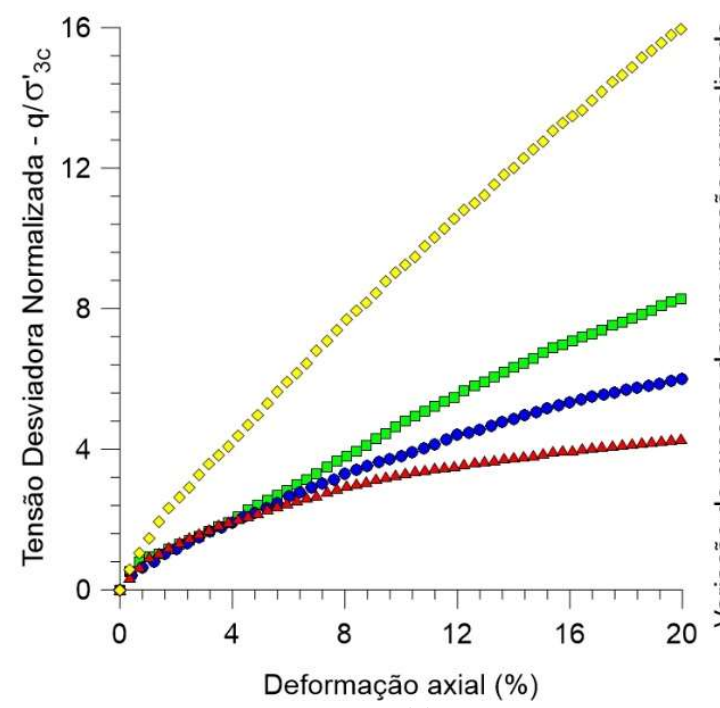

(e)

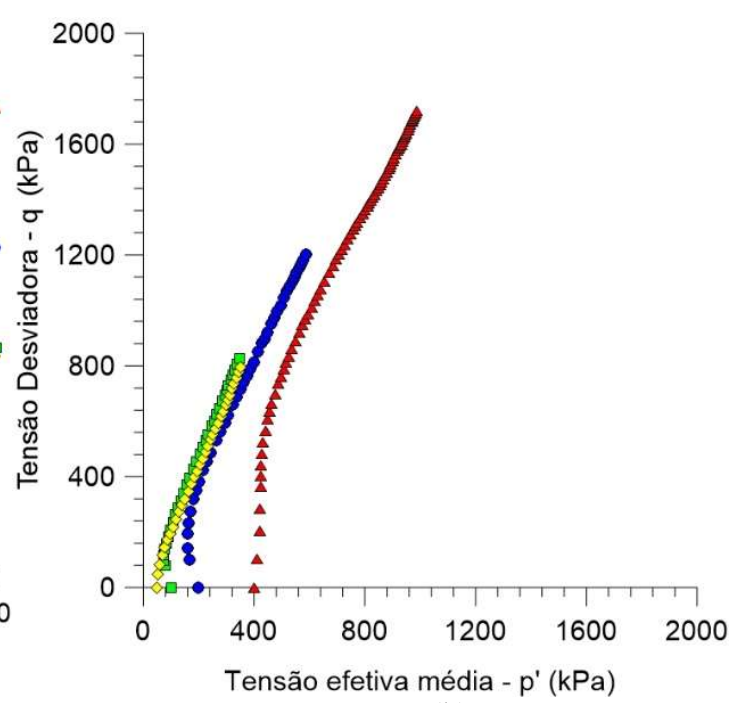

(b)

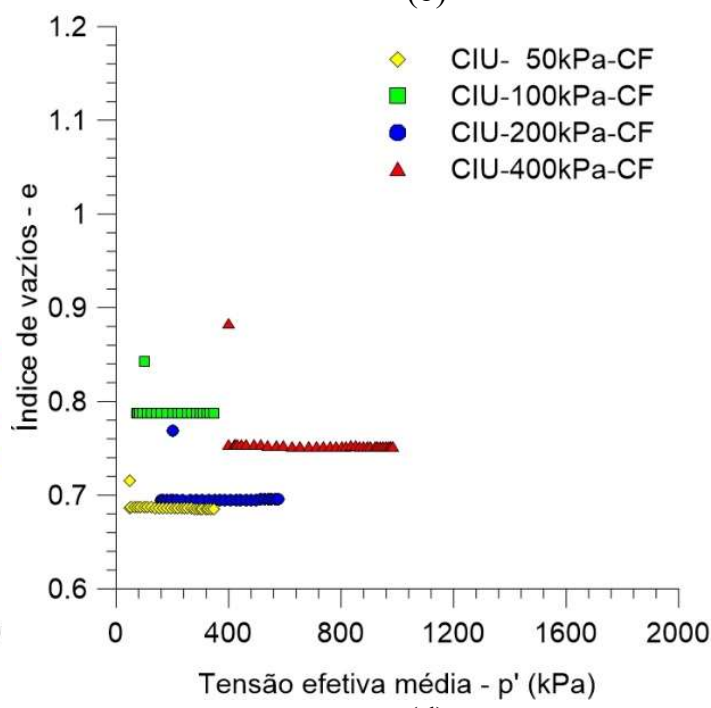

(d)

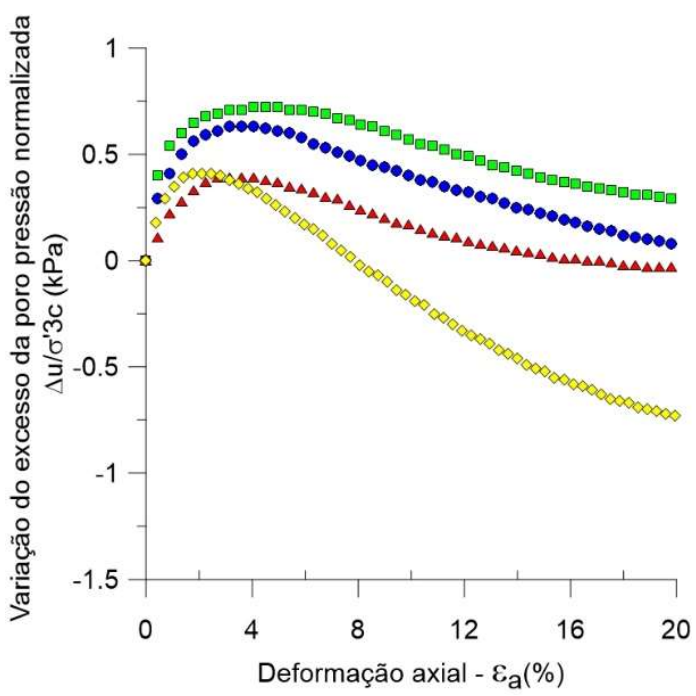

(f)

Figura 5.9. Resultados dos ensaios triaxiais reforçado CU (RMAu) Rejeito de Minério de Ouro 
$\mathrm{Na}$ Figura 5.8(c), as poropressões $(\Delta \mathrm{u})$ também incrementam rapidamente entre (1-2\%) seguidas de uma redução até o final do ensaio. Essa redução é maior quanto mais baixo é o nível de tensão efetiva de confinamento.

A Figura 5.8(d) mostra a variação dos índices de vazios e vs. p' desde a fase de adensamento isotrópico até o final do cisalhamento. Como o ensaio é não drenado, não se apresentará variação do índice de vazios, mas a Figura pretende verificar a variação de p' com referência ao estado crítico. A Figura 5.8(e) apresenta as curvas de tensão desviadora normalizada, onde é possível observar que em baixas tensões possuem um comportamento diferente das altas tensões.

Baixas tensões $(50 \mathrm{kPa}$ e $100 \mathrm{kPa})$ atingem uma tensão desviadora normalizada de pico e depois continuam incrementando seu valor de forma constante, enquanto tensões altas (200 kPa e $400 \mathrm{kPa})$ atingem um valor de pico e não mais apresentam variação.

O acréscimo de tensão desviadora normalizada pode ser associado a uma constante reestruturação dos grãos de rejeito de minério de ouro que não acontece nas maiores tensões. Isto reflete na Figura 5.8(f), que mostra como em baixas tensões o excesso de poropressão normalizada chega a um valor de pico e depois tem uma maior redução quando comparada com as amostras submetidas a altas tensões. Quando as partículas se movimentam, o excesso de poropressão é liberado mostrando esse comportamento.

Nos rejeitos de minério de ouro reforçados, a Figura 5.9(a) mostra que as fibras incrementam de maneira considerável o valor da tensão desviadora de forma constante. Nota-se que, a medida que aumenta a tensão efetiva de confinamento o incremento da tensão desviadora passa de ser linear para parabólica mostrando, em tensões de $200 \mathrm{kPa}$ e $400 \mathrm{kPa}$, um pequeno decréscimo da tensão desviadora até o final do ensaio.

Na Figura 5.9(b), a trajetória de tensão correspondente à tensão efetiva de $50 \mathrm{kPa}$ e $400 \mathrm{kPa}$ mantêm a direção quase vertical apresentada no rejeito não reforçado se inclinando para a direita até atingir a envoltória. As tensões de $100 \mathrm{kPa}$ e $200 \mathrm{kPa}$ conservam a trajetória direcionada para a esquerda no início da compressão, inclinando-se para a direita ao atingir a envoltória até $20 \%$ de deformação axial. Na Figura 5.9(c) nota-se que as poropressões $(\Delta \mathrm{u})$ incrementam rapidamente entre de $2-4 \%$ de deformação axial maior do que no caso não reforçado. Após atingir uma variação do excesso de poropressão de pico segue uma 
redução que é menor em baixas tensões, enquanto para altas tensões efetivas de confinamento a redução é drástica. A Figura 5.9(d) mostra que a tensão média efetiva p' alcançada com referência à máxima deformação axial do ensaio é comparativamente maior do que no caso não reforçado. A Figura 5.9(e) apresenta as curvas de tensão desviadora normalizada mostrando um comportamento similar em todas as curvas até o final do ensaio. Nota-se que as tensões de 100, 200 e 400 $\mathrm{kPa}$ apresentam a mesma inclinação até 4\% de deformação axial mostrando que, após atingir o valor de pico da variação do excesso de poropressão, o comportamento pós-pico do material é dependente da tensão efetiva de confinamento. A Figura 5.9(f) mostra que o comportamento da variação do excesso de poropressão normalizada é similar em tensões de 100, 200 e $400 \mathrm{kPa}$ e diferente na tensão de $50 \mathrm{kPa}$ portanto o reforço de fibra modifica o comportamento do material significativamente a partir de tensões superiores a $100 \mathrm{kPa}$. A Figura 5.10 mostra que a adição de reforço modifica a razão de tensões efetivas.

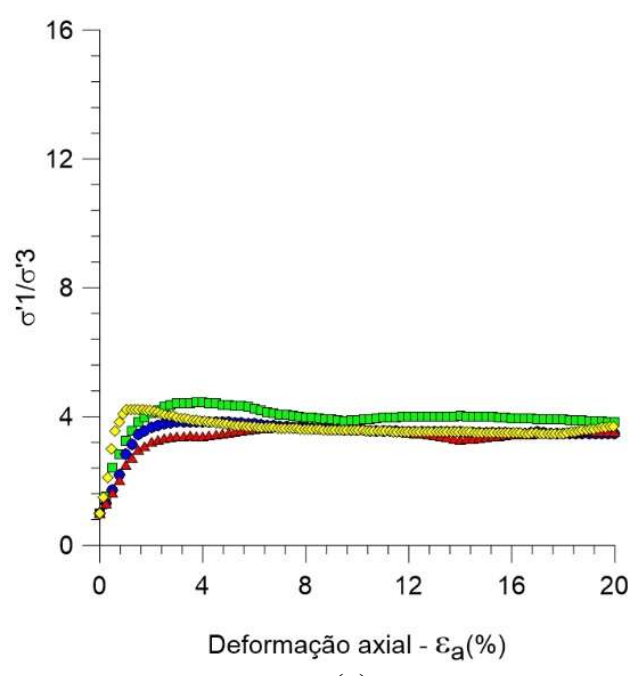

(a)

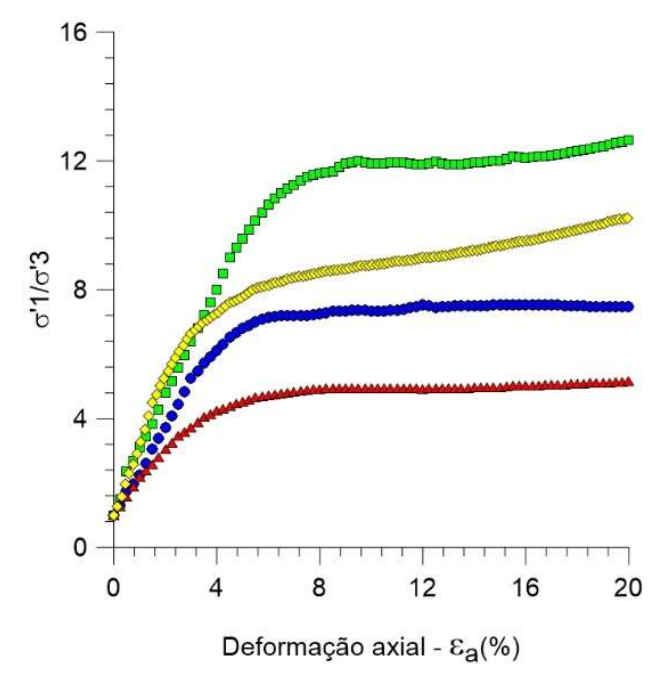

(b)

Figura 5.10. Razão de tensões principais efetivas (RMAu) Rejeito de Minério de Ouro (a) não reforçado (b) reforçado

\subsection{3.}

\section{Linha de estado Crítico (LEC)}

A linha de estado crítico é a linha que representa os pontos da condição última ou crítica alcançada por uma amostra de solo, tanto em condições drenadas como não drenadas. Ela é obtida quando depois de ser adensada isotropicamente, a amostra é submetida ao cisalhamento triaxial até grandes deformações onde não apresenta variações na tensão efetiva média, no índice de vazios ou no volume 
especifico. A equação 5.1 da LEC denota o estado crítico com o subíndice "c". M é a inclinação da LEC no espaço p' vs. q.

$q_{c}=M \cdot p^{\prime}{ }_{c}$

O critério de ruptura de Mohr-Coulomb na compressão axial é relacionado com a linha do estado crítico na equação:

$M=\frac{6 \cdot \operatorname{sen} \phi^{\prime}{ }_{c}}{3-\operatorname{sen} \phi^{\prime}{ }_{c}}$

Onde, $\phi{ }^{\prime}$ c é o ângulo de atrito no estado crítico.

A obtenção do estado crítico é complexa e é normalmente alcançada em grandes deformações as quais possuem outras considerações como a resistência da membrana, efeitos de embarrigamento do corpo de prova ou limitações do equipamento triaxial, portanto os pontos usados neste trabalho são uma aproximação ao estado crítico. A linha de estado crítico foi determinada para cada rejeito de minério usando os ensaios CD e CU. No caso drenado, os pontos devem ter alcançado uma deformação volumétrica constante. No caso não drenado, os pontos devem ter uma razão de tensões médias efetivas $\sigma_{1}{ }_{1} / \sigma^{\prime}{ }_{3}$, constante. Nas Tabelas 5.5 e 5.6 são apresentados os pontos do espaço p'-q usados no desenho da linha de estado crítico do rejeito de minério de ferro.

Tabela 5.5. Linha de Estado Crítico não reforçado (RMFe) Rejeito de Minério de Ferro

\begin{tabular}{|c|c|c|c|c|c|c|}
\hline Tipo & Ensaio & Critério & $\begin{array}{c}\text { Tensão } \\
\text { Confinante } \\
\text { efetiva } \\
(\mathrm{kPa}) \\
\end{array}$ & $\begin{array}{c}\varepsilon_{\mathrm{a}} \\
(\%)\end{array}$ & $\begin{array}{c}\mathrm{p}^{\prime} \\
(\mathrm{kPa})\end{array}$ & $\begin{array}{c}\mathrm{q} \\
(\mathrm{kPa})\end{array}$ \\
\hline \multirow{6}{*}{$\begin{array}{l}\text { Não } \\
\text { Reforçado }\end{array}$} & \multirow{2}{*}{$\mathrm{CD}$} & $\% \varepsilon_{\mathrm{v} \text { cte. }}$ & 200 & 20,0 & 377,5 & 532,5 \\
\hline & & $\% \varepsilon_{\mathrm{v}}$ cte. & 400 & 20,0 & 734,7 & 1004,0 \\
\hline & \multirow{4}{*}{$\mathrm{CU}$} & $\left(\sigma_{1}^{\prime} / \sigma^{\prime}\right)_{\text {cte. }}$. & 50 & 0,35 & 52,6 & 71,8 \\
\hline & & $\left(\sigma_{1}^{\prime} / \sigma^{\prime}\right)_{\text {cte. }}$. & 100 & 0,65 & 177,8 & 237,6 \\
\hline & & $\left(\sigma_{1}{ }_{1} / \sigma^{\prime}\right)_{\text {cte. }}$ & 200 & 1,00 & 271,8 & 381,9 \\
\hline & & $\left(\sigma^{\prime}{ }_{1} / \sigma^{\prime}\right)_{\text {cte. }}$. & 400 & 1,80 & 601,5 & 807,4 \\
\hline
\end{tabular}

Tabela 5.6. Suposta Linha de Estado Crítico reforçado (RMFe)

\begin{tabular}{|c|c|c|c|c|c|c|}
\hline Tipo & Ensaio & Critério & $\begin{array}{c}\text { Tensão } \\
\text { Confinante } \\
\text { efetiva } \\
(\mathrm{kPa})\end{array}$ & $\begin{array}{c}\varepsilon_{\mathrm{a}} \\
(\%)\end{array}$ & $\begin{array}{c}\mathrm{p}^{\prime} \\
(\mathrm{kPa})\end{array}$ & $\begin{array}{c}\mathrm{q} \\
(\mathrm{kPa})\end{array}$ \\
\hline \multirow{5}{*}{ Reforçado } & $\mathrm{CD}$ & $\% \varepsilon_{\mathrm{v} \text { cte. }}$ & 400 & 20,0 & 963,3 & 1689,9 \\
\hline & \multirow{4}{*}{$\mathrm{CU}$} & $\left(\sigma_{1}^{\prime} / \sigma^{\prime}\right)_{\text {cte. }}$ & 50 & 0,60 & 80,0 & 126,5 \\
\hline & & $\left.\left(\sigma_{1}{ }_{1} / \sigma^{\prime}\right)_{3}\right)_{\text {cte. }}$ & 100 & 0,95 & 99,6 & 165,0 \\
\hline & & $\left(\sigma^{\prime}{ }_{1} / \sigma^{\prime}\right)_{\text {cte. }}$ & 200 & 1,05 & 231,4 & 397,4 \\
\hline & & $\left(\sigma_{1}^{\prime} / \sigma^{\prime}\right)_{\text {cte. }}$ & 400 & 1,95 & 740,3 & 1271,3 \\
\hline
\end{tabular}


Na Figura 5.11(a) se mostra o ajuste linear do rejeito de minério de ferro não reforçado que passa pela origem dos pontos correspondentes à condição última do ensaio se obtendo $M=1,366$ que resulta em um ângulo de atrito crítico de 33,8 .

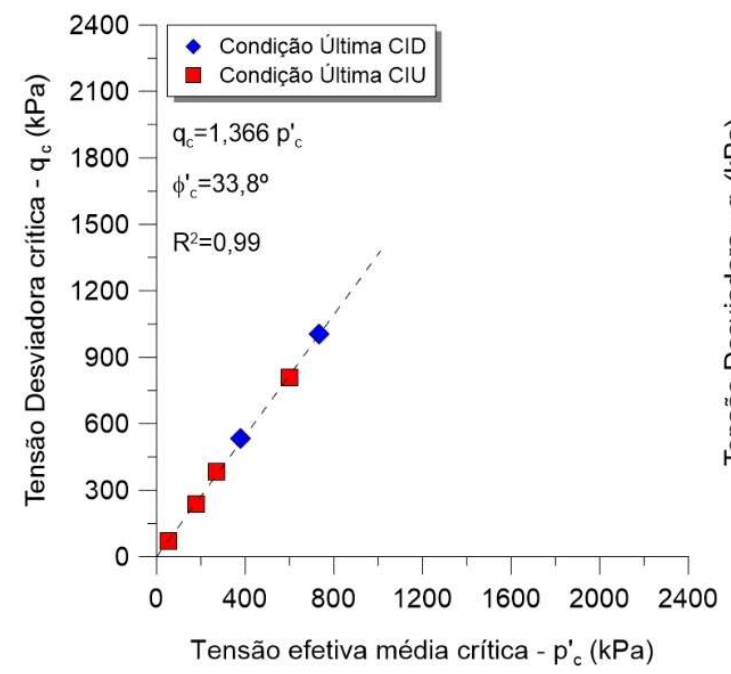

(a)

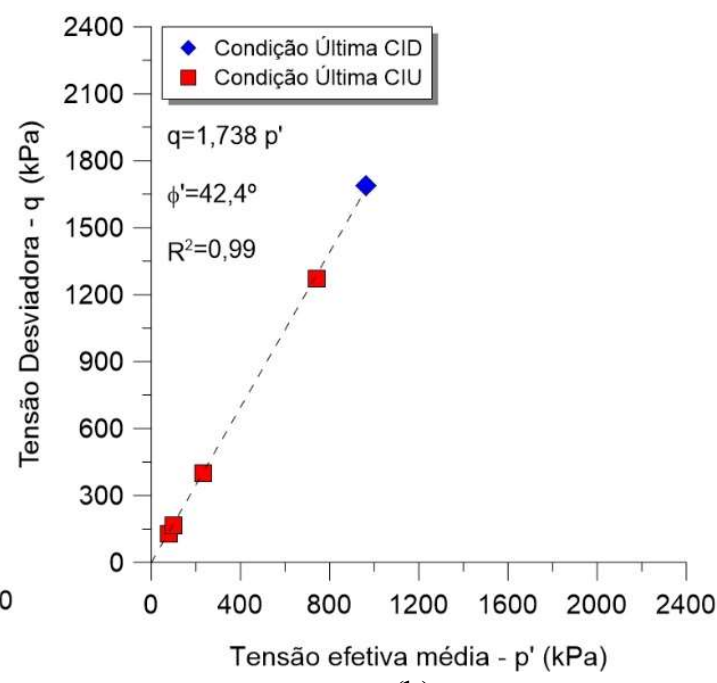

(b)

Figura 5.11. Linha do estado crítico (RMFe)

(a) não reforçado (b) reforçado

Rejeito de minério de ferro

$\mathrm{Na}$ tentativa de entender se as condições que definem os pontos próximos ao estado crítico podem ser aplicadas para rejeitos de minério reforçados com fibras, são plotados na Figura 5.11(b) os pontos descritos na Tabela 5.6. Nota-se que a correlação linear é ótima se obtendo um $\mathrm{M}=1,738$ que corresponde a um ângulo de atrito mobilizado de $42,4^{\circ}$.

É importante destacar que o marco do estado crítico não se aplica para todos os tipos de solos. Martins et al., (2011) indicaram que há categorias como os solos arenosos não uniformes com finos plásticos, ou areias com teores entre 20 a 30\% de finos, que não se comportam em compressão de acordo com o mostrado na literatura e, portanto, a teoria do estado crítico não pode ser aplicada com os mesmos termos.

No caso dos rejeitos reforçados com fibras, não existe um marco teórico para determinar um estado crítico, portanto, o desenho da suposta linha que apresentouse neste caso tenta ilustrar a mudança do ângulo de atrito crítico se existisse um rejeito com as características mecânicas do compósito fibroso.

A Figura 5.12 mostra as linhas de estado crítico não reforçada e reforçada junto com as trajetórias de tensão não drenadas. 


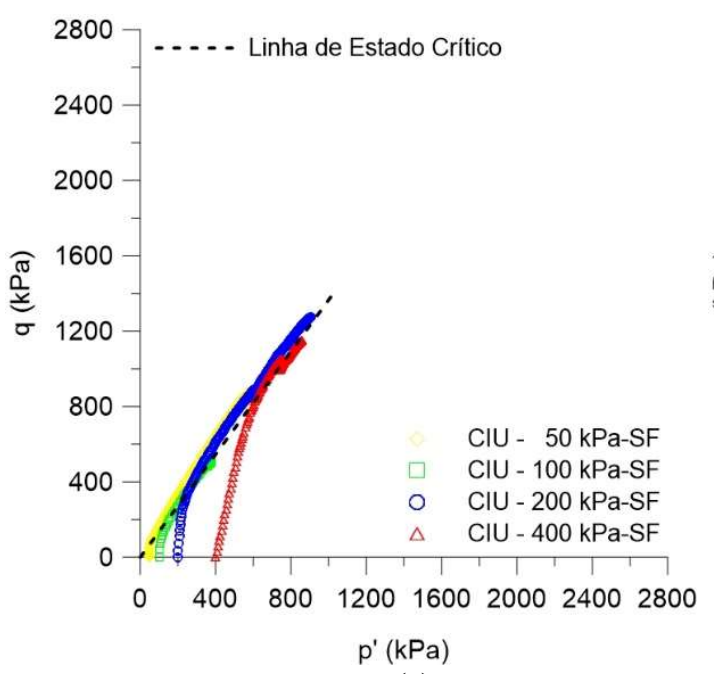

(a)

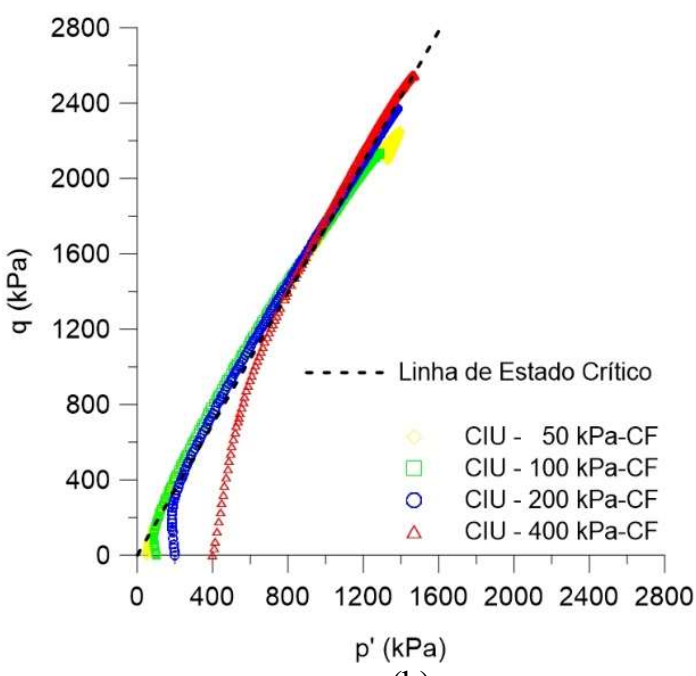

(b)

Figura 5.12. Trajetórias não drenadas e linha de estado crítico (RMFe)

(a) não reforçado (b) reforçado

Rejeito de minério de ferro

No caso do rejeito de minério de ouro, a estimação de uma suposta linha de estado crítico foi mais complicada porque pelas limitações do equipamento não foi possível conseguir uma maior deformação axial, sobretudo no caso reforçado que apresentou um constante incremento de tensão desviadora, portanto as trajetórias de tensão não conseguem formar uma envoltória crítica onde as trajetórias de tensão CU e CD convergem.

Nesse sentido, as trajetórias foram extrapoladas, supondo que se conserva a tendência de incremento da tensão desviadora, até que as curvas CU e CD se cruzem em um ponto que será utilizado para desenhar a suposta linha de estado crítico do rejeito de ouro reforçado.

As Tabelas 5.7 e 5.8 mostram os pontos usados no espaço p'-q, os critérios adotados para seu emprego foram os mesmos utilizados no rejeito de minério de ferro.

Tabela 5.7. Linha de Estado Crítico não reforçado (RMAu)

Rejeito de Minério de Ouro

\begin{tabular}{|c|c|c|c|c|c|c|}
\hline Tipo & Ensaio & Critério & $\begin{array}{c}\text { Tensão } \\
\text { Confinante } \\
\text { efetiva } \\
(\mathrm{kPa})\end{array}$ & $\begin{array}{c}\varepsilon_{\mathrm{a}} \\
(\%)\end{array}$ & $\begin{array}{c}\mathrm{p}^{\prime} \\
(\mathrm{kPa})\end{array}$ & $\underset{(\mathrm{kPa})}{\mathrm{q}}$ \\
\hline \multirow{5}{*}{$\begin{array}{c}\text { Não } \\
\text { Reforçado }\end{array}$} & $\mathrm{CD}$ & $\% \varepsilon_{\mathrm{v} \text { cte. }}$ & 400 & 20,0 & 709,1 & 927,3 \\
\hline & \multirow{4}{*}{$\mathrm{CU}$} & $\left(\sigma^{\prime}{ }_{1} / \sigma^{\prime}{ }_{3}\right)_{\text {cte. }}$ & 50 & 0,55 & 55,5 & 74,8 \\
\hline & & $\left.\left(\sigma_{1}{ }_{1} / \sigma^{\prime}\right)_{3}\right)_{\text {cte. }}$ & 100 & 1,55 & 124,0 & 181,3 \\
\hline & & $\left(\sigma^{\prime}{ }_{1} / \sigma^{\prime}{ }_{3}\right)_{\text {cte. }}$ & 200 & 1,55 & 182,4 & 246,0 \\
\hline & & $\left(\sigma_{1}^{\prime} / \sigma^{\prime}\right)_{\text {cte. }}$ & 400 & 2,30 & 405,6 & 525,6 \\
\hline
\end{tabular}


Tabela 5.8. Suposta Linha de Estado Crítico reforçado (RMAu)

Rejeito de Minério de Ouro

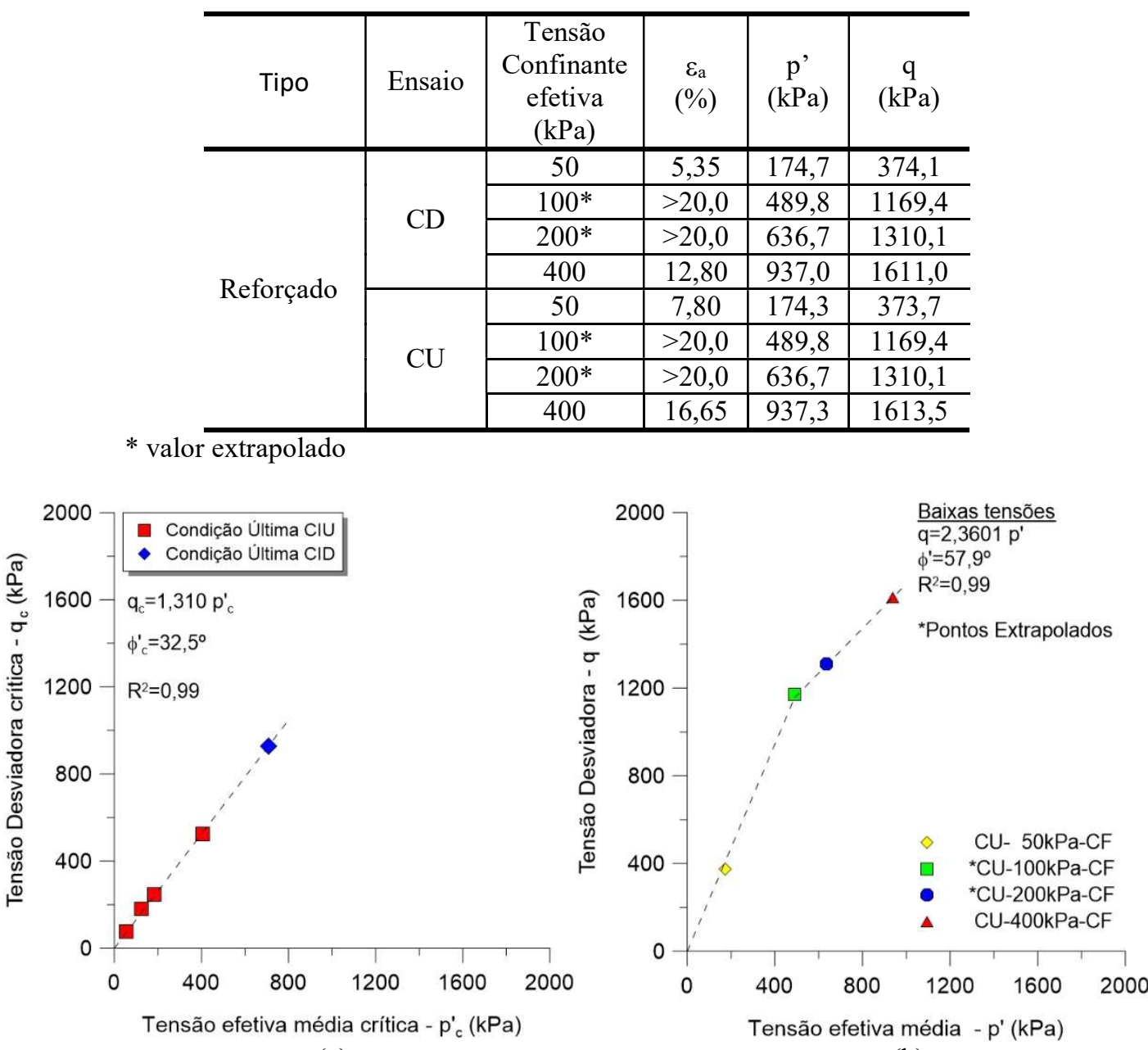

(a)

(b)

Figura 5.13. Linha do estado crítico (RMAu)

(a) não reforçado (b) reforçado

Rejeito de minério de ouro

A Figura 5.13 apresenta a linha de estado crítico do rejeito de minério de ouro não reforçado e reforçado. No caso não reforçado, o ajuste mostra um comportamento linear que passa pelo origem com um $M=1,310$ obtendo um ângulo de atrito crítico de $32,5^{\circ}$. No caso reforçado, o ajuste mostra um comportamento bi linear que passa pela origem obtendo $M=2,3601$ que resulta em um ângulo de atrito crítico de $57,9^{\circ}$, embora, o resultado seja por extrapolação, neste cálculo se pretende mostrar que a fibra muda o estado crítico dos rejeitos de mineração. $\mathrm{O}$ interessante é a bi-linearidad da envoltória quando os pontos no espaço $\mathrm{p}^{\prime}-\mathrm{q}$ dos ensaios não drenados e drenados coincidem. É importante indicar que não existe um marco teórico para determinar a linha de estado crítico em solos fibroreforçados.

A Figura 5.14 mostra as linhas de estado crítico não reforçada e reforçada junto com as trajetórias de tensão não drenadas. 


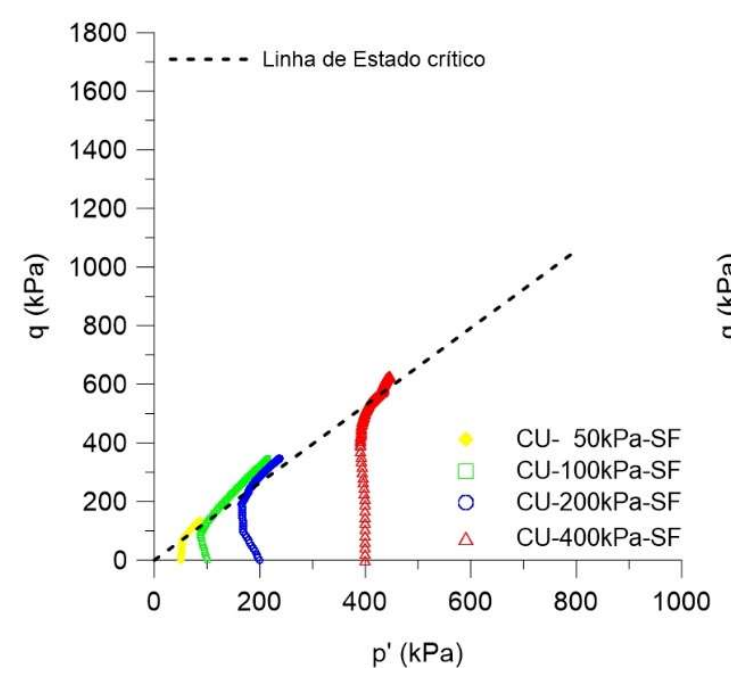

(a)

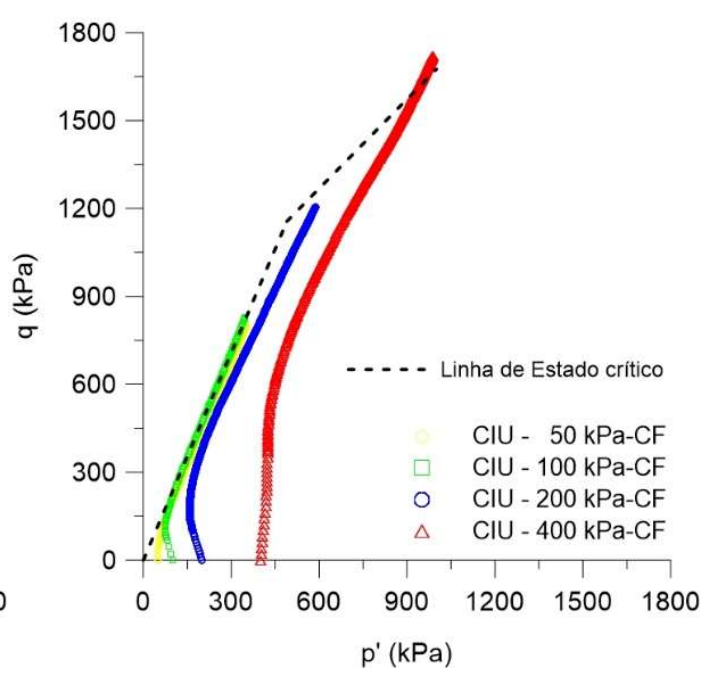

(b)

Figura 5.14. Trajetórias não drenadas e linha de estado crítico (RMAu)

(a) não reforçado (b) reforçado

Rejeito de minério de ouro

\subsection{4.}

\section{Envoltórias e Parâmetros de Resistência}

Para calcular os parâmetros de resistência utilizou-se o Modelo de Cambridge, portanto foram determinados os pontos s' vs. t, considerando a tensão desviadora de pico $\left(\mathrm{q}_{\max }\right)$ e, quando o rejeito apresentou um comportamento strainhardening, a razão de tensões médias efetivas para definir o valor de pico $\left(\sigma^{\prime}{ }_{1} / \sigma^{\prime}{ }_{3}\right)_{\text {máx. }}$ ou o ponto onde começa a fissuração da matriz $\left(\sigma^{\prime}{ }_{1} / \sigma^{\prime}{ }_{3}\right)_{\text {pend. }}$.

Os ensaios foram realizados até alcançar $20 \%$ da deformação axial em todas as amostras. Nota-se que rejeitos reforçados apresentam um incremento constante da tensão desviadora. Assumindo que após $20 \%$ de deformação axial, a tendência continua portanto o valor obtido neste nível de deformação não é o máximo.

As fibras começam a atuar quando as partículas da matriz não conseguem continuar se deslocando sem interatuar com as fibras. No caso reforçado não há presença de tensão desviadora de pico porque a fibra incrementa a resistência ao cisalhamento, portanto considera-se que o começo da fissuração da matriz acontece na mudança da inclinação da curva tensão desviadora vs. deformação axial.

\subsubsection{1.}

\section{Rejeito de Minério de Ferro}

$\mathrm{Na}$ Tabela 5.9 e 5.10 apresentam-se os pontos e critérios utilizados para desenhar as envoltórias de resistência do rejeito de minério de ferro. Usam-se os 
critérios de tensão desviadora máxima $\left(\mathrm{q}_{\text {máx }}\right)$ e da razão de tensões máxima $\left(\sigma^{\prime}{ }_{1} / \sigma^{\prime}{ }_{3}\right)_{\text {máx. }}$

Tabela 5.9. Envoltória de Resistência não reforçado (RMFe) Rejeito de Minério de Ferro

\begin{tabular}{|c|c|c|c|c|c|c|c|c|}
\hline Tipo & Ensaio & $\begin{array}{c}\text { Tensão } \\
\text { Confinante } \\
\text { efetiva } \\
(\mathrm{kPa})\end{array}$ & Critério & $\begin{array}{c}\varepsilon \\
(\%)\end{array}$ & $\begin{array}{c}\mathrm{p}^{\prime} \\
(\mathrm{kPa})\end{array}$ & $\underset{(\mathrm{kPa})}{\mathrm{q}}$ & $\begin{array}{c}\sigma^{\prime} 1 \\
(\mathrm{kPa})\end{array}$ & $\begin{array}{c}\sigma^{\prime} 3 \\
(\mathrm{kPa})\end{array}$ \\
\hline \multirow{8}{*}{$\begin{array}{c}\text { Não } \\
\text { Reforçado }\end{array}$} & \multirow{4}{*}{$\mathrm{CD}$} & 50 & $\mathrm{q}_{\text {máx. }}$ & 1,25 & 139,6 & 268,7 & 318,7 & 50 \\
\hline & & 100 & q máx. & 2,00 & 202,1 & 306,1 & 406,1 & 100 \\
\hline & & 200 & $\mathrm{q}_{\text {máx. }}$ & 2,20 & 394,4 & 583,3 & 783,3 & 200 \\
\hline & & 400 & q máx. & 3,05 & 761,1 & 1083,4 & 1483,4 & 400 \\
\hline & \multirow{4}{*}{$\mathrm{CU}$} & 50 & $\left(\sigma^{\prime}{ }_{1} / \sigma^{\prime}{ }_{3}\right)_{\text {máx. }}$ & 1,45 & 289.1 & 169,8 & 362,5 & 73,4 \\
\hline & & 100 & $\left(\sigma_{1}{ }_{1} / \sigma^{\prime}{ }_{3}\right)_{\text {máx. }}$ & 2,75 & 360,2 & 509,4 & 699,8 & 190,4 \\
\hline & & 200 & $\left(\sigma^{\prime}{ }_{1} / \sigma^{\prime}{ }_{3}\right)_{\text {máx. }}$ & 2,65 & 435,1 & 664,7 & 878,2 & 213,5 \\
\hline & & 400 & $\left(\sigma_{1}^{\prime} / \sigma^{\prime}{ }_{3}\right)_{\text {maxx }}$. & 3,35 & 708,9 & 1007,7 & 1280,7 & 373,1 \\
\hline
\end{tabular}

Tabela 5.10. Envoltória de Resistência reforçado (RMFe) Rejeito de Minério de Ferro

\begin{tabular}{|c|c|c|c|c|c|c|c|c|}
\hline Tipo & Ensaio & $\begin{array}{c}\text { Tensão } \\
\text { Confinante } \\
\text { efetiva } \\
(\mathrm{kPa})\end{array}$ & Critério & $\begin{array}{c}\varepsilon \\
(\%)\end{array}$ & $\begin{array}{c}\mathrm{p}^{\prime} \\
(\mathrm{kPa})\end{array}$ & $\begin{array}{c}\mathrm{q} \\
(\mathrm{kPa})\end{array}$ & $\begin{array}{c}\sigma^{\prime} 1 \\
(\mathrm{kPa})\end{array}$ & $\begin{array}{c}\sigma^{\prime} 3 \\
(\mathrm{kPa})\end{array}$ \\
\hline \multirow{8}{*}{ Reforçado } & \multirow{4}{*}{$\mathrm{CD}$} & 50 & $\bar{q}$ máx. & 6,00 & 260,4 & 631,3 & 681,3 & 50 \\
\hline & & 100 & q máx. & 6,30 & 348,9 & 746,9 & 846,9 & 100 \\
\hline & & 200 & $\mathrm{q}$ máx. & 7,10 & 582,4 & 1147,2 & 1347,3 & 200 \\
\hline & & 400 & $\mathrm{q}$ máx. & 9,00 & 1006,6 & 1819,7 & 2219,7 & 400 \\
\hline & \multirow{4}{*}{$\mathrm{CU}$} & 50 & $\left.\left(\sigma_{1}{ }_{1} / \sigma^{\prime}\right)_{3}\right)_{\text {máx. }}$ & 1,85 & 220,1 & 421,7 & 501,2 & 79,5 \\
\hline & & 100 & $\left.\left(\sigma^{\prime}{ }_{1} / \sigma^{\prime}\right)_{3}\right)_{\text {máx. }}$ & 2,15 & 211,3 & 438,0 & 503,3 & 65,3 \\
\hline & & 200 & $\left.\left(\sigma^{\prime}{ }_{1} / \sigma^{\prime}\right)_{3}\right)_{\text {máx. }}$ & 2,15 & 391,7 & 734,0 & 881,0 & 147,1 \\
\hline & & 400 & $\left.\left(\sigma_{1}{ }_{1} / \sigma^{\prime}\right)_{3}\right)_{\text {máx. }}$ & 4,60 & 1144,5 & 2053,4 & 2513,5 & 460,1 \\
\hline
\end{tabular}

Com o intuito de entender se existe diferença entre os resultados drenados e não drenados, na Figura 5.15 apresentam-se as envoltórias de resistência para ambas as condições do rejeito de minério de ferro não reforçado e reforçado com os parâmetros de resistência correspondentes. Usa-se a notação s' $=\left(\sigma^{\prime}{ }_{1}+\sigma^{\prime}{ }_{3}\right) / 2 \mathrm{e}$ $\mathrm{t}^{\prime}=\left(\sigma^{\prime}{ }_{1}-\sigma^{\prime}{ }_{3}\right) / 2$.

Note-se que pelo reforço, na condição drenada, um importante acréscimo obtido no intercepto coesivo de 28 a $103 \mathrm{kPa}$, enquanto o ângulo de atrito aumenta de $33^{\circ}$ a $39^{\circ}$. Na condição não drenada, o incremento significativo é dado pelo ângulo de atrito de $33^{\circ}$ a $42^{\circ}$, enquanto o incremento no intercepto coesivo é desprezível.

Na Figura 5.16 apresenta-se a envoltória de resistência usando todos os ensaios, drenados e não drenados para definir os parâmetros do rejeito de minério de ferro não reforçado e reforçado. 


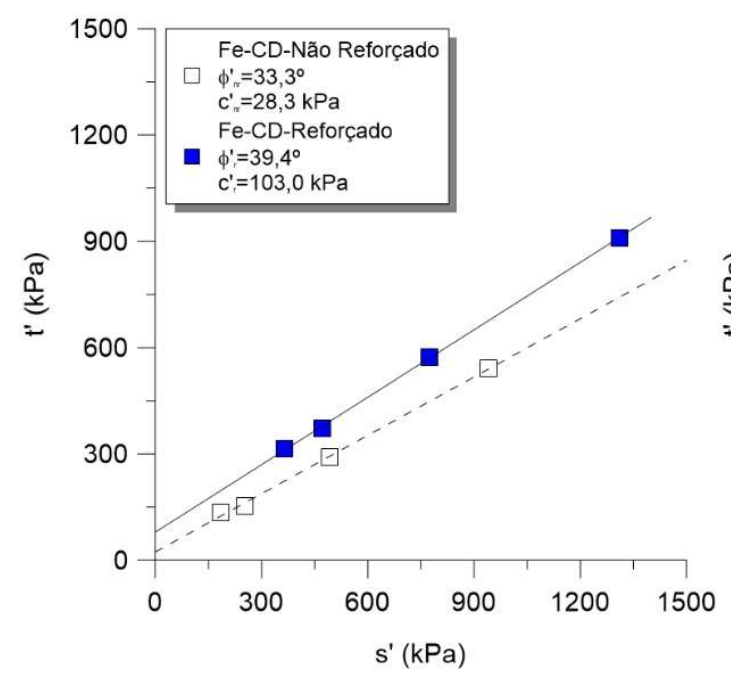

(a)

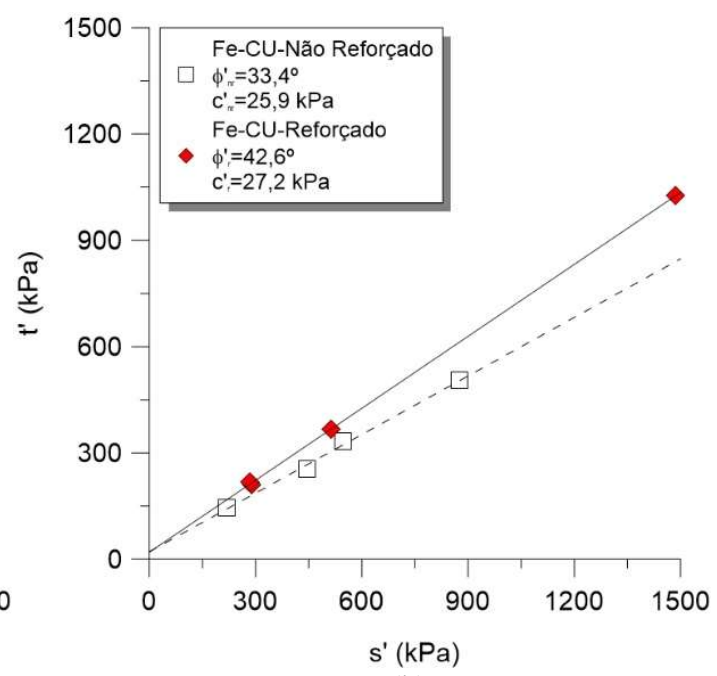

(b)

Figura 5.15. Envoltória de resistência (a) drenada e (b) não drenada (RMFe) Rejeito de Minério de Ferro

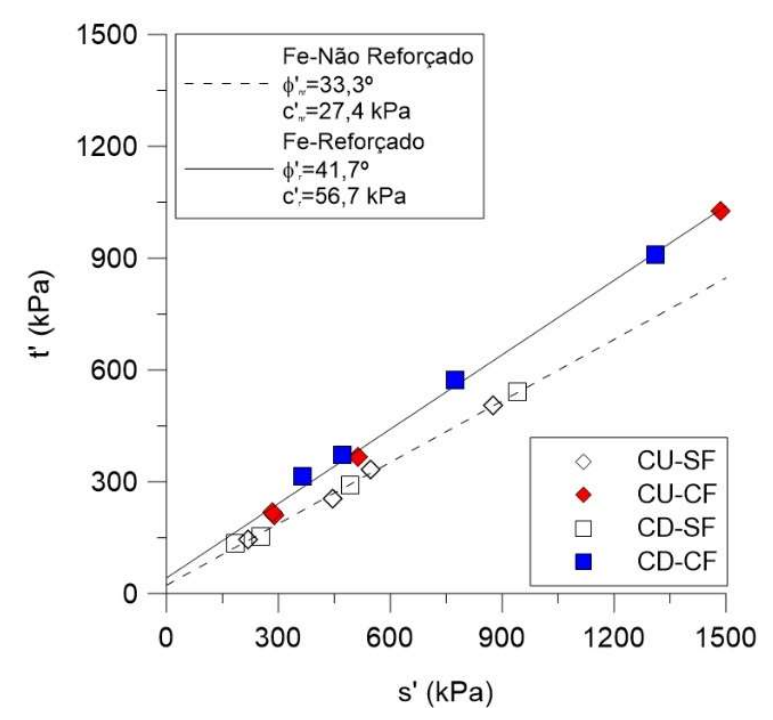

Figura 5.16. Envoltória de resistência não reforçada e reforçada final (RMFe) Rejeito de Minério de Ferro

Finalmente, observa-se que a adição de fibra favorece o incremento dos parâmetros de resistência do rejeito de minério de ferro no ângulo de atrito de $33^{\circ}$ a $41^{\circ}$ e de 27 a $56 \mathrm{kPa}$ no intercepto coesivo.

Na Figura 5.17 apresentam-se as envoltórias de resistência no espaço p' vs. q, ajustada nos pontos obtidos segundo os critérios descritos nas Tabelas 5.9 e 5.10, para o rejeito de minério de ferro não reforçado e reforçado, também são apresentadas as trajetórias de tensão dos ensaios CD e CU, nas Figuras colocam-se também as linhas de estado crítico. 


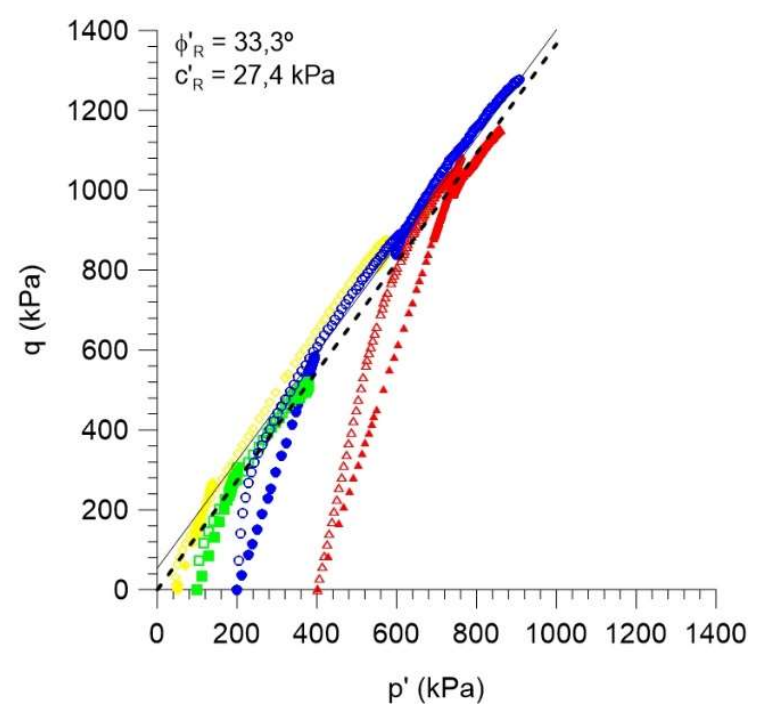

(a)
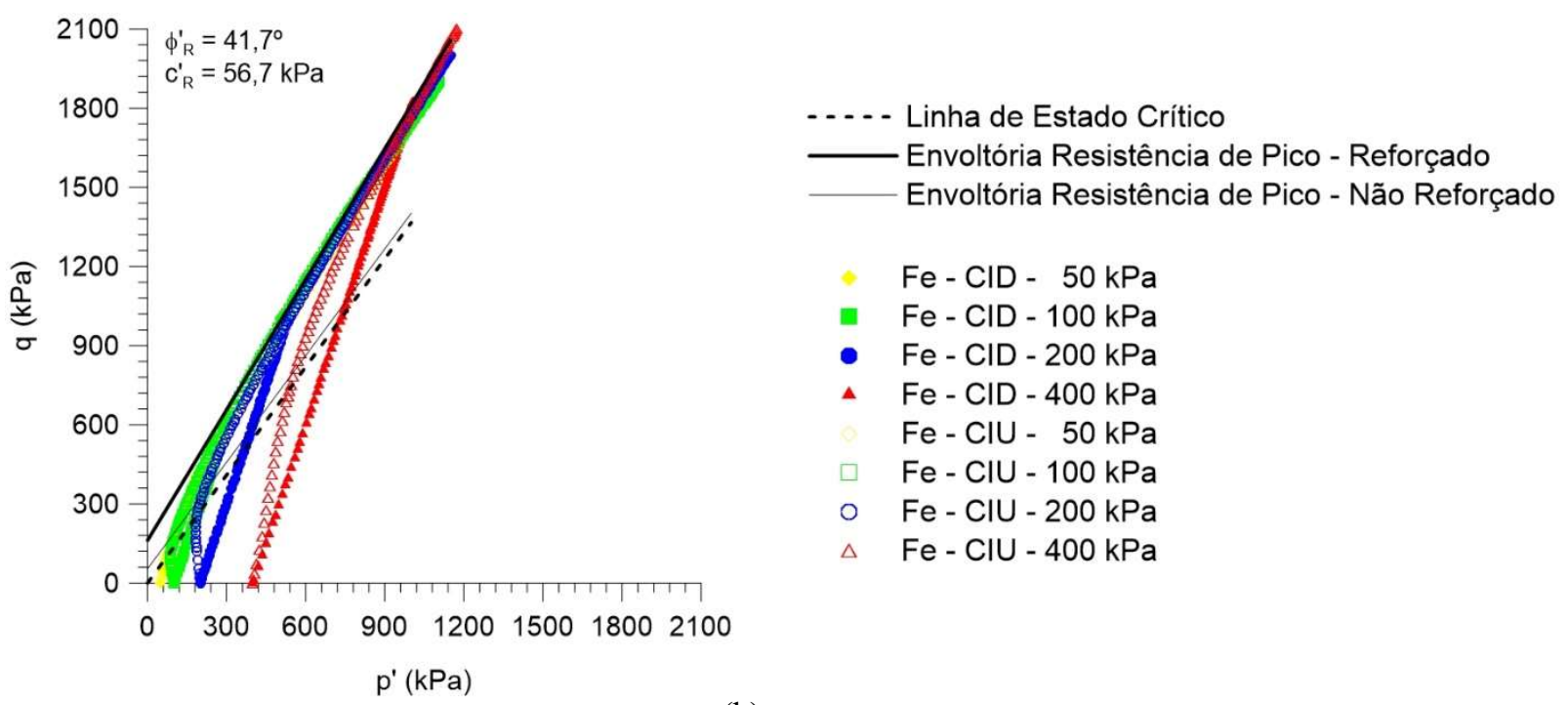

(b)

Figura 5.17. Trajetórias de tensão (RMFe)

(a) não reforçado (b) reforçado

\subsubsection{2.}

\section{Rejeito de Minério de Ouro}

Nas Tabelas 5.11 e 5.12 apresentam-se os critérios utilizados para elaborar a envoltória de resistência do rejeito de minério de ouro não reforçado e reforçado respectivamente. Usam-se os critérios de tensão desviadora máxima ( $\mathrm{q}_{\text {máx }}$ ), razão de tensões máxima $\left(\sigma^{\prime}{ }_{1} / \sigma^{\prime}{ }_{3}\right)_{\text {máx. }}$, e do começo da fissuração da matriz $\left(\sigma_{1}{ }_{1} / \sigma^{\prime}{ }_{3}\right)_{\text {pend }}$.

O comportamento reforçado é strain-hardening e na Tabela 5.12 aparecem os pontos que correspondem ao $20 \%$ de deformação axial para calcular parâmetros de resistência e fazer a comparação com a resistência máxima adotada. 
Tabela 5.11. Envoltória de Resistência não reforçada (RMAu)

Rejeito de Minério de Ouro

\begin{tabular}{|c|c|c|c|c|c|c|c|c|}
\hline Tipo & Ensaio & $\begin{array}{c}\text { Tensão } \\
\text { Confinante } \\
\text { efetiva } \\
(\mathrm{kPa}) \\
\end{array}$ & Critério & $\begin{array}{c}\varepsilon \mathrm{a} \\
(\%)\end{array}$ & $\begin{array}{c}\mathrm{p}^{\prime} \\
(\mathrm{kPa})\end{array}$ & $\underset{(\mathrm{kPa})}{\mathrm{q}}$ & $\begin{array}{c}\sigma^{\prime} 1 \\
(\mathrm{kPa})\end{array}$ & $\begin{array}{c}\sigma^{\prime} 3 \\
(\mathrm{kPa})\end{array}$ \\
\hline \multirow{8}{*}{$\begin{array}{c}\text { Não } \\
\text { Reforçado }\end{array}$} & \multirow{4}{*}{ CD } & 50 & $\mathrm{q}$ máx. & 2,70 & 119,4 & 208,2 & 258,2 & 50 \\
\hline & & 100 & q máx. & 4,70 & 191,0 & 273,1 & 373,1 & 100 \\
\hline & & 200 & q máx. & 4,60 & 377,2 & 531,8 & 731,8 & 200 \\
\hline & & 400 & q máx. & 7,55 & 748,6 & 1045,7 & 1445,7 & 400 \\
\hline & \multirow{4}{*}{$\mathrm{CU}$} & 50 & $\left(\sigma^{\prime}{ }_{1} / \sigma^{\prime}\right)_{\text {máx. }}$ & 1,50 & 87,0 & 135,4 & 117,3 & 41,9 \\
\hline & & 100 & $\left(\sigma^{\prime}{ }_{1} / \sigma^{\prime}\right)_{\text {máx. }}$ & 4,00 & 215,6 & 346,0 & 446,3 & 100,3 \\
\hline & & 200 & $\left(\sigma_{1} / \sigma^{\prime}\right)_{\text {máx. }}$ & 4,00 & 238,1 & 347,2 & 469,5 & 122,3 \\
\hline & & 400 & $\left(\sigma^{\prime}{ }_{1} / \sigma^{\prime}\right)_{\text {máx. }}$ & 7,50 & 446,2 & 628,3 & 865,0 & 236,7 \\
\hline
\end{tabular}

Tabela 5.12. Envoltória de Resistência reforçada (RMAu) Rejeito de Minério de Ouro

\begin{tabular}{|c|c|c|c|c|c|c|c|c|}
\hline Tipo & Ensaio & $\begin{array}{l}\text { Tensão } \\
\text { Confinante } \\
\text { efetiva } \\
(\mathrm{kPa})\end{array}$ & Critério & $\begin{array}{l}\varepsilon \mathrm{a} \\
(\%)\end{array}$ & $\begin{array}{c}\text { p' } \\
(\mathrm{kPa})\end{array}$ & $\begin{array}{c}\mathrm{q} \\
(\mathrm{kPa})\end{array}$ & $\begin{array}{c}\sigma^{\prime} 1 \\
(\mathrm{kPa})\end{array}$ & $\begin{array}{c}\sigma^{\prime} 3 \\
(\mathrm{kPa})\end{array}$ \\
\hline \multirow{16}{*}{ Reforçado } & \multirow{8}{*}{$\mathrm{CD}$} & 50 & $\left(\sigma^{\prime}{ }_{1} / \sigma^{\prime}{ }_{3}\right)_{\text {pend. }}$ & 4,80 & 170,5 & 361,5 & 411,5 & 50 \\
\hline & & 100 & $\left(\sigma^{\prime}{ }_{1} / \sigma^{\prime}{ }_{3}\right)$ pend. & 7,00 & 276,6 & 529,9 & 629,9 & 100 \\
\hline & & 200 & $\left(\sigma_{1}^{\prime} / \sigma^{\prime}{ }_{3}\right)_{\text {pend. }}$ & 6,50 & 529,9 & 989,9 & 1189,9 & 200 \\
\hline & & 400 & $\left(\sigma_{1}^{\prime} / \sigma^{\prime}{ }_{3}\right)_{\text {pend. }}$ & 8,00 & 876,2 & 1428,6 & 1828,6 & 400 \\
\hline & & 50 & $\varepsilon_{\mathrm{a}}=20 \%$ & 20,00 & 268,2 & 654,7 & 741,3 & 50 \\
\hline & & 100 & $\varepsilon_{\mathrm{a}}=20 \%$ & 20,00 & 377,1 & 831,3 & 978,6 & 100 \\
\hline & & 200 & $\varepsilon_{\mathrm{a}}=20 \%$ & 20,00 & 625,4 & 1276,1 & 1516,6 & 200 \\
\hline & & 400 & $\varepsilon_{\mathrm{a}}=20 \%$ & 20,00 & 977,5 & 1732,5 & 2106,8 & 400 \\
\hline & \multirow{8}{*}{$\mathrm{CU}$} & 50 & $\left.\left(\sigma_{1}^{\prime} / \sigma^{\prime}\right)_{3}\right)_{\text {pend. }}$ & 6,15 & 142,9 & 302,4 & 344,5 & 42,1 \\
\hline & & 100 & $\left(\sigma_{1}^{\prime} / \sigma_{3}^{\prime}\right)_{\text {pend. }}$ & 9,30 & 186,2 & 438,5 & 478,5 & 40,0 \\
\hline & & 200 & $\left.\left(\sigma_{1}^{\prime} / \sigma^{\prime}\right)_{3}\right)_{\text {pend.. }}$ & 6,30 & 272,2 & 549,4 & 638,5 & 89,0 \\
\hline & & 400 & $\left(\sigma_{1}{ }_{1} / \sigma_{3}^{\prime}\right)_{\text {pend. }}$ & 7,45 & 667,0 & 1128,8 & 1419,5 & 290,7 \\
\hline & & 50 & $\varepsilon_{\mathrm{a}}=20 \%$ & 20,00 & 352,8 & 798,8 & 885,3 & 86,5 \\
\hline & & 100 & $\varepsilon_{\mathrm{a}}=20 \%$ & 20,00 & 348,3 & 830,7 & 902,1 & 71,4 \\
\hline & & 200 & $\varepsilon_{\mathrm{a}}=20 \%$ & 20,00 & 586,5 & 1202,5 & 1388,2 & 185,7 \\
\hline & & 400 & $\varepsilon_{\mathrm{a}}=20 \%$ & 20,00 & 987,7 & 1719,9 & 2134,3 & 414,4 \\
\hline
\end{tabular}

Na Figura 5.18 apresentam-se as envoltórias de resistência para os ensaios drenados e não drenados do rejeito de minério de ouro não reforçado e reforçado com os parâmetros de resistência correspondentes. Usa-se a notação s' $=\left(\sigma^{\prime}{ }_{1}+\sigma^{\prime}{ }_{3}\right) / 2$ e $t^{\prime}=\left(\sigma^{\prime}{ }_{1}-\sigma^{\prime}{ }_{3}\right) / 2$. Observa-se que, tanto na condição drenada e não drenada, o incremento dos parâmetros de resistência é similar.

$\mathrm{Na}$ Figura 5.19 apresenta-se a envoltória de resistência usando todos os ensaios, drenados e não drenados para definir os parâmetros do rejeito de minério de ouro não reforçado e reforçado. Observa-se que a adição de fibra favorece o 
incremento dos parâmetros de resistência do rejeito de minério de ouro no ângulo de atrito de $33,5^{\circ}$ a $37,4^{\circ}$ e de 14,7 a $62,3 \mathrm{kPa}$ no intercepto coesivo.

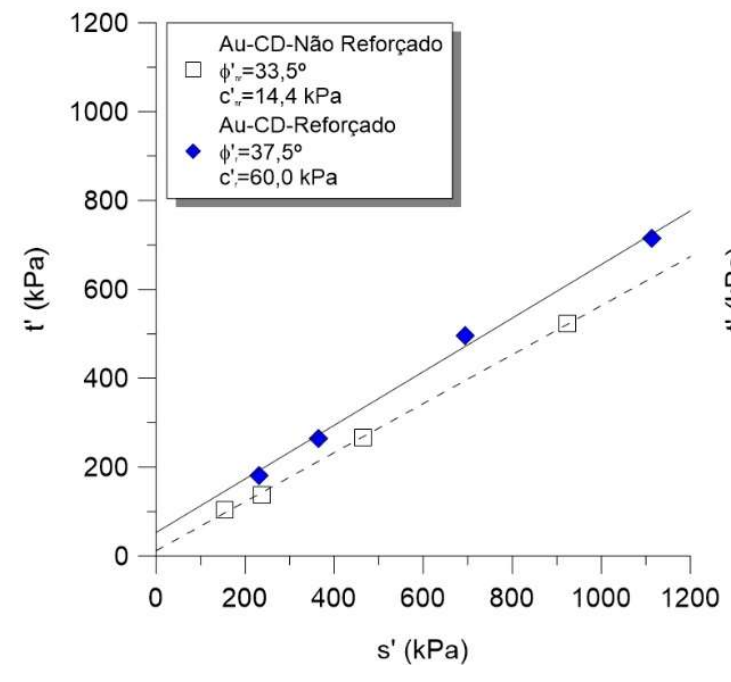

(a)

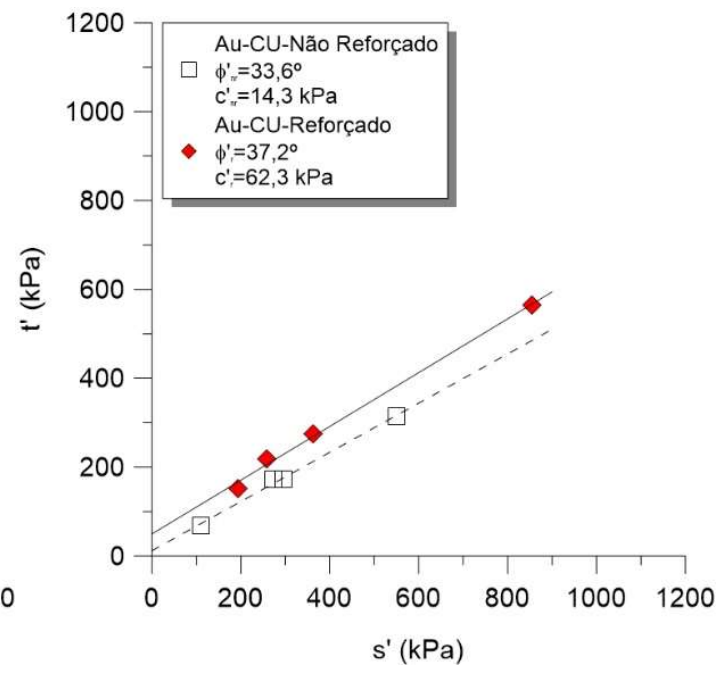

(b)

Figura 5.18. Envoltória de resistência (a) drenada e (b) não drenada (RMAu) Rejeito de Minério de Ouro

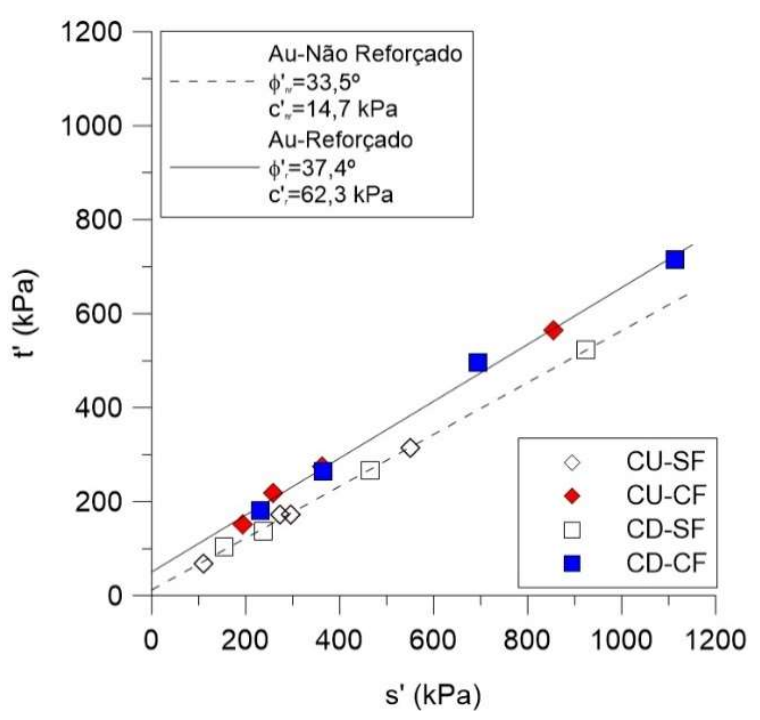

Figura 5.19. Envoltória de resistência não reforçada e reforçada final (RMAu) Rejeito de Minério de Ouro

Na Figura 5.20 apresentam-se as envoltórias de resistência de pico e ao 20\% de deformação axial no espaço q vs. p', ajustada nos pontos obtidos segundo os critérios descritos nas Tabelas 5.9 e 5.10, para o rejeito de minério de ouro não reforçado e reforçado, também são apresentadas as trajetórias de tensão dos ensaios CD e CU e a linha de estado crítico. 


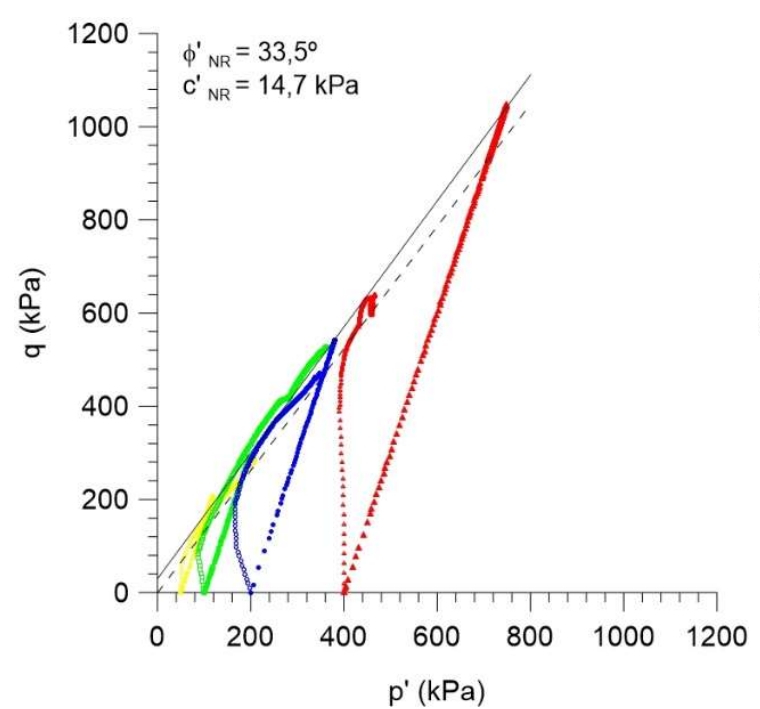

(a)

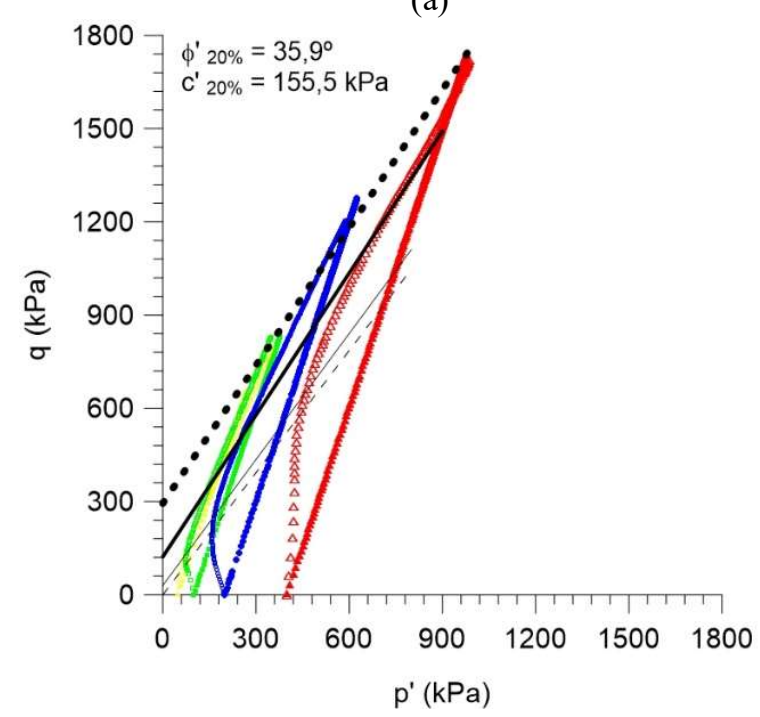

(c)

Figura 5.20. Trajetórias de tensão (RMAu)

(a) não reforçado (b) reforçado (c) reforçado ao $20 \%$ de deformação

Observa-se na Figura 5.20(c) que, considerando os pontos de $20 \%$ de deformação axial, o intercepto coesivo aumenta 10 vezes o valor não reforçado. Com respeito aos parâmetros obtidos tomando em conta o início da fissuração, na Figura 5.20(b), o valor do intercepto coesivo é mais conservador e a diferença entre ângulos de atrito é de $1,5^{\circ}$, portanto é importante ter esta consideração na estimativa dos parâmetros em projetos que envolvam rejeitos com reforço de fibras.

\subsection{5.}

Módulo de deformabilidade e relação de deformações

O solo comporta-se elasticamente no campo sob pequenas tensões, portanto, considera-se o módulo secante como aquele que melhor descreve o comportamento do solo (Lambe \& Whitman (1969); Briaud, 2001). Lambe \& Whitman (1969) 
apresentaram o módulo de elasticidade do solo como o módulo secante de uma tensão desviadora zero até uma tensão desviadora igual à metade da tensão desviadora de pico.

Nos ensaios triaxiais é comum usar o módulo tangente inicial (Ei), onde a relação é quase linear. Neste trabalho, a relação tensão vs. deformação é definida pelo Módulo de deformabilidade ( $\left.\mathrm{E}_{50}\right)$ que descreve melhor o comportamento não linear do rejeito. Para determinar a influência da fibra no módulo de deformabilidade usa-se o critério do módulo secante de Lambe \& Whitman (1969), até $10 \%$ de deformação axial, porque todos os pontos máximos utilizados para desenhar as envoltórias de resistência localizam-se nesta faixa de deformação, limitando a influência inicial à fase pós ruptura não reforçada e à fase de strainhardening reforçada, como mostra a Figura 5.21.

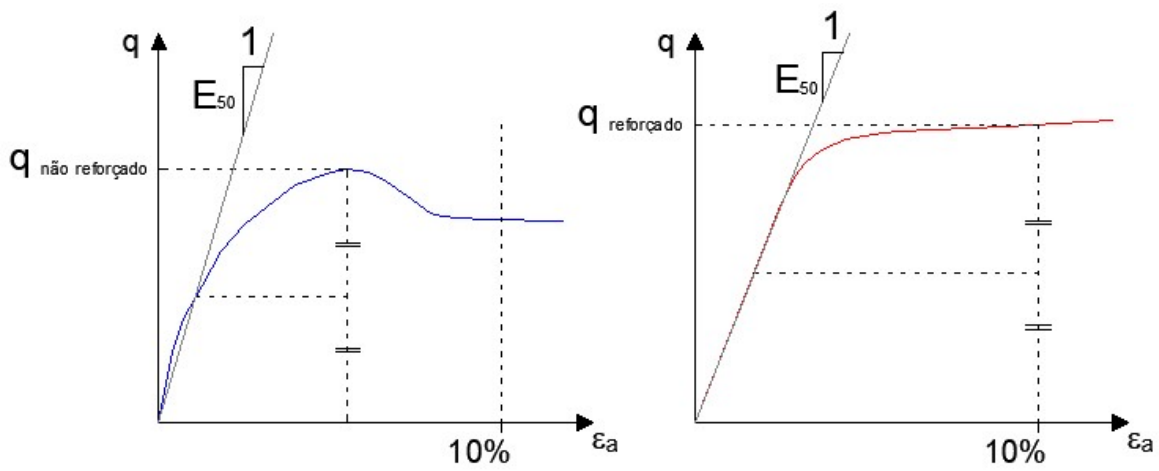

Figura 5.21. Esquema do módulo de deformabilidade em rejeito de minério

Quando é aplicado o carregamento no ensaio triaxial produz-se uma deformação radial e axial, o valor absoluto é denominado neste trabalho como relação de deformações $\left(\varepsilon_{\mathrm{r}} / \varepsilon_{\mathrm{a}}\right)$. Para comparar a influência da fibra nas deformações laterais do corpo de prova, esta relação é calculada antes e após da ruptura ou do começo da fissuração do material compósito tomando como padrão $1 \%$ e $10 \%$ de deformação axial, porque todos os pontos máximos utilizados para desenhar as envoltórias de resistência localizam-se nesta faixa de deformação.

\subsubsection{1.}

\section{Rejeito de Minério de Ferro}

As Tabelas 5.13 e 5.14 mostram o módulo de deformabilidade $\left(E_{50}\right)$ e a relação de deformações $\left(\varepsilon_{\mathrm{r}} / \varepsilon_{\mathrm{a}}\right)$ no rejeito de minério de ferro não reforçado e reforçado, respectivamente. 
Tabela 5.13. $\mathrm{E}_{50}$ e $\varepsilon_{\mathrm{r}} / \varepsilon_{\mathrm{a}}$ - não reforçado (RMFe) Rejeito de Minério de Ferro

\begin{tabular}{|c|c|c|c|c|c|c|}
\hline \multirow[b]{2}{*}{ Tipo } & \multirow[b]{2}{*}{ Ensaio } & \multirow{2}{*}{$\begin{array}{c}\text { Tensão } \\
\text { Confinante } \\
\text { efetiva } \\
(\mathrm{kPa})\end{array}$} & \multicolumn{2}{|c|}{$\begin{array}{c}\text { Módulo de } \\
\text { deformabilidade }\end{array}$} & \multicolumn{2}{|c|}{$\begin{array}{c}\text { Relação de } \\
\text { deformações }\end{array}$} \\
\hline & & & $\begin{array}{l}\varepsilon_{\mathrm{a}} \\
(\%)\end{array}$ & $\begin{array}{c}\mathrm{E}_{50} \\
(\mathrm{MPa})\end{array}$ & $\begin{array}{c}\varepsilon_{\mathrm{r}} / \varepsilon_{\mathrm{a}} \\
\varepsilon_{\mathrm{a}}=1 \%\end{array}$ & $\begin{array}{c}\varepsilon_{\mathrm{r}} / \varepsilon_{\mathrm{a}} \\
\varepsilon_{\mathrm{a}}=10 \%\end{array}$ \\
\hline \multirow{8}{*}{$\begin{array}{l}\text { Não } \\
\text { reforçado }\end{array}$} & \multirow{4}{*}{ CD } & 50 & 0,44 & 30,5 & 0,38 & 0,33 \\
\hline & & 100 & 0,34 & 45,1 & 0,39 & 0,40 \\
\hline & & 200 & 0,40 & 73,2 & 0,59 & 0,45 \\
\hline & & 400 & 0,69 & 78,0 & 0,65 & 0,48 \\
\hline & \multirow{4}{*}{$\mathrm{CU}$} & 50 & 0,45 & 18,9 & - & - \\
\hline & & 100 & 0,75 & 34,0 & - & - \\
\hline & & 200 & 0,75 & 44,3 & - & - \\
\hline & & 400 & 0,90 & 56,0 & - & - \\
\hline
\end{tabular}

Tabela 5.14. $\mathrm{E}_{50}$ e $\varepsilon_{\mathrm{r}} / \varepsilon_{\mathrm{a}}-$ reforçado (RMFe) Rejeito de Minério de Ferro

\begin{tabular}{|c|c|c|c|c|c|c|}
\hline \multirow[b]{2}{*}{ Tipo } & \multirow[b]{2}{*}{ Ensaio } & \multirow{2}{*}{$\begin{array}{c}\text { Tensão } \\
\text { Confinante } \\
\text { efetiva } \\
(\mathrm{kPa})\end{array}$} & \multicolumn{2}{|c|}{$\begin{array}{c}\text { Módulo de } \\
\text { deformabilidade }\end{array}$} & \multicolumn{2}{|c|}{$\begin{array}{c}\text { Relação de } \\
\text { deformações }\end{array}$} \\
\hline & & & $\begin{array}{c}\varepsilon_{\mathrm{a}} \\
(\%)\end{array}$ & $\begin{array}{c}E_{50} \\
(\mathrm{MPa})\end{array}$ & $\begin{array}{c}\varepsilon_{\mathrm{r}} / \varepsilon_{\mathrm{a}} \\
\varepsilon_{\mathrm{a}}=1 \%\end{array}$ & $\begin{array}{c}\varepsilon_{\mathrm{r}} / \varepsilon_{\mathrm{a}} \\
\varepsilon_{\mathrm{a}}=10 \%\end{array}$ \\
\hline \multirow{8}{*}{ Reforçado } & \multirow{4}{*}{$\mathrm{CD}$} & 50 & 1,59 & 22,6 & 0,48 & 0,23 \\
\hline & & 100 & 1,39 & 26,9 & 0,61 & 0,28 \\
\hline & & 200 & 1,55 & 37,8 & 0,69 & 0,37 \\
\hline & & 400 & 1,39 & 65,5 & 0,84 & 0,37 \\
\hline & \multirow{4}{*}{$\mathrm{CU}$} & 50 & 1,00 & 21,1 & - & - \\
\hline & & 100 & 1,25 & 17,5 & - & - \\
\hline & & 200 & 0,95 & 38,6 & - & - \\
\hline & & 400 & 1,45 & 70,8 & - & - \\
\hline
\end{tabular}

A Figura 5.22 mostra a variação do módulo de deformabilidade com a tensão efetiva de confinamento.

No rejeito não reforçado, o incremento do módulo de deformabilidade drenado é linear até a tensão de $200 \mathrm{kPa}$ depois o incremento se reduz, embora, continua aumentando. Isto mostra que em altas tensões efetivas existe uma estabilização do módulo de deformabilidade porque um nível de tensão efetiva alto gera uma matriz mais densa e um comportamento mais rígido.

Observa-se que a adição de fibra diminui o módulo de deformabilidade drenado, para um mesmo nível de tensão efetiva, mas com a tendência de ser maior em tensões altas, como mostra o módulo não drenado reforçado.

A Figura 5.23 mostra a variação da relação de deformações com o aumento da tensão efetiva de confinamento. 


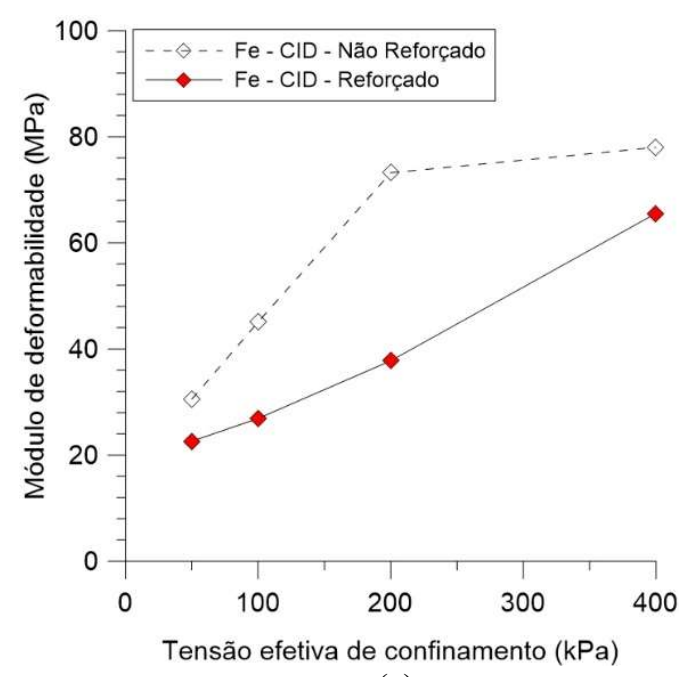

(a)

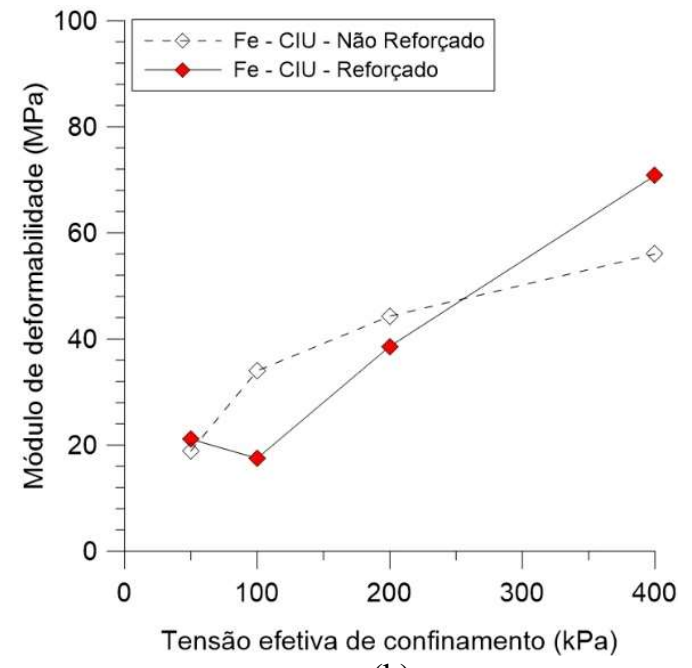

(b)

Figura 5.22. Módulo de deformabilidade (RMFe)

(a) drenado (b) não drenado

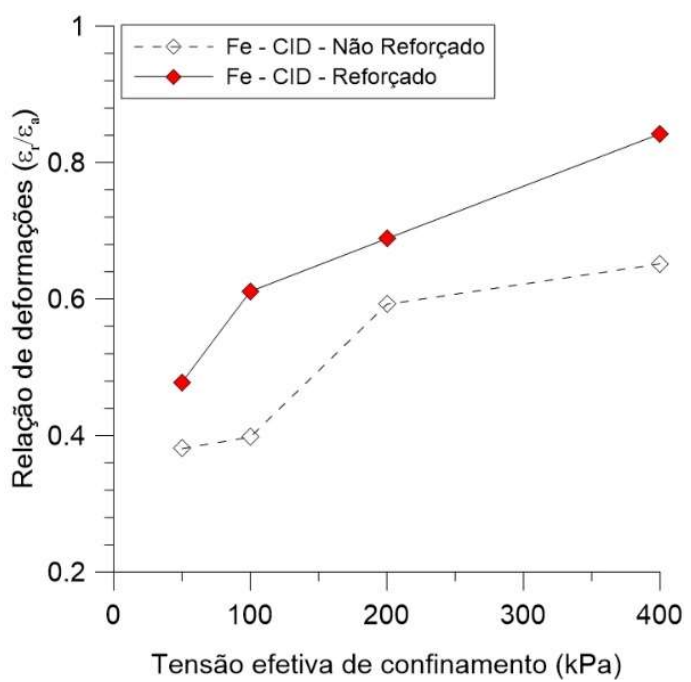

(a)

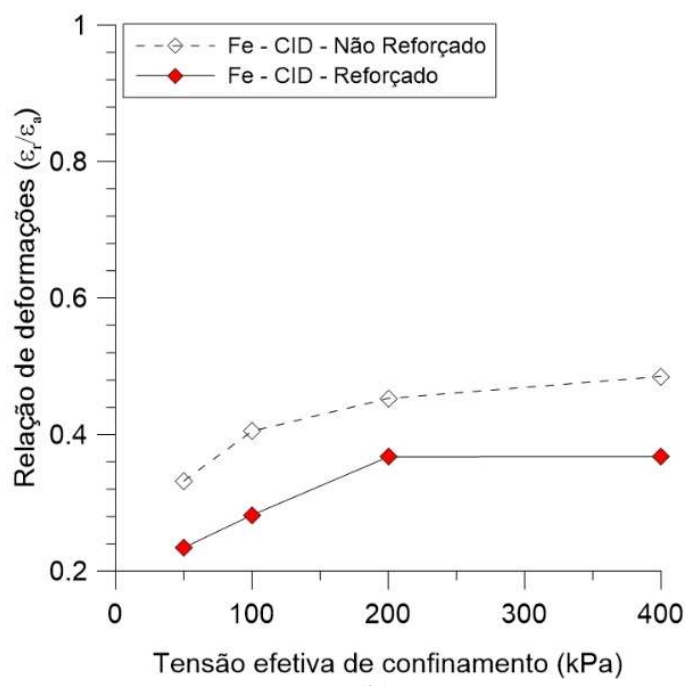

(b)

Figura 5.23. Relação de deformações (RMFe)

(a) $\varepsilon \mathrm{a}=1 \%$ (a) $\varepsilon \mathrm{a}=10 \%$

Antes da ruptura na deformação de 1\%, como mostra a Figura 5.23(a), a relação de deformações reforçada tem uma tendência a aumentar com o incremento da tensão efetiva de confinamento essa tendência é repetida após a ruptura em 10\% de deformação axial até se mostrar estável.

A diferença é que, antes do começo da fissuração da matriz, o rejeito reforçado apresenta uma relação de deformações maior do que não reforçado, com valores maiores de 0,5 mostrando que as fibras aumentam as deformações radiais ou laterais da matriz no início do ensaio, posteriormente, com o aumento da deformação axial e tensões desviadoras, melhora a interação fibra-grão e as fibras 
começam a permanecer presas no entrosamento do rejeito segurando os grãos e reduzindo as deformações laterais, isto é verificado na Figura 5.23(b) onde nota-se que a relação de deformações reforçada é menor do que o valor não reforçado.

A Figura 5.24 mostra um esquema da interação das fibras com o entrosamento do rejeito de minério de ferro, o desenvolvimento de forças perpendiculares e tangenciais permitem que a fibra diminua o rolamento entre grãos.

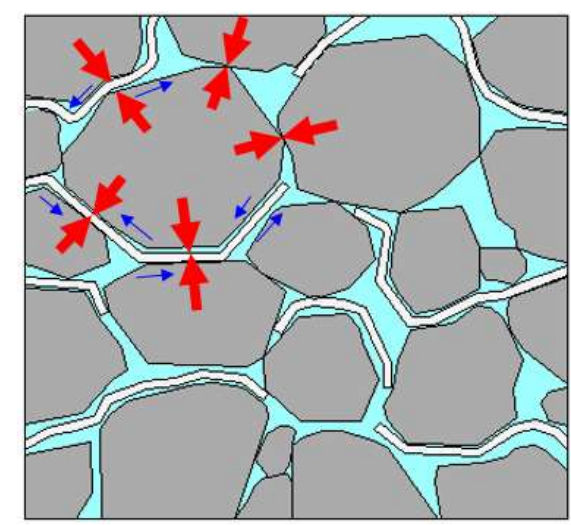

Figura 5.24. Interação fibra-grão durante a deformação axial (RMFe) Rejeito de Minério de Ferro

\subsubsection{2.}

\section{Rejeito de Minério de Ouro}

As Tabelas 5.15 e 5.16 mostram o módulo de deformabilidade $\left(\mathrm{E}_{50}\right)$ e a relação de deformações $\left(\varepsilon_{\mathrm{r}} / \varepsilon_{\mathrm{a}}\right)$ no rejeito de minério de ouro não reforçado e reforçado, respectivamente. No caso do rejeito de minério de ouro, a Figura 5.25 também mostra um incremento do módulo de deformabilidade com o incremento da tensão efetiva de confinamento.

Tabela 5.15. $\mathrm{E}_{50}$ e $\varepsilon_{\mathrm{r}} / \varepsilon_{\mathrm{a}}$ - não reforçado (RMAu) Rejeito de Minério de Ouro

\begin{tabular}{|c|c|c|c|c|c|c|}
\hline \multirow[b]{2}{*}{ Tipo } & \multirow[b]{2}{*}{ Ensaio } & \multirow{2}{*}{$\begin{array}{c}\text { Tensão } \\
\text { Confinante } \\
\text { efetiva } \\
(\mathrm{kPa})\end{array}$} & \multicolumn{2}{|c|}{$\begin{array}{c}\text { Módulo de } \\
\text { deformabilidade }\end{array}$} & \multicolumn{2}{|c|}{$\begin{array}{c}\text { Relação de } \\
\text { deformações }\end{array}$} \\
\hline & & & $\begin{array}{l}\varepsilon_{\mathrm{a}} \\
(\%)\end{array}$ & $\begin{array}{c}\mathrm{E}_{50} \\
(\mathrm{MPa}) \\
\end{array}$ & $\begin{array}{c}\varepsilon_{\mathrm{r}} / \varepsilon_{\mathrm{a}} \\
\varepsilon_{\mathrm{a}}=1 \%\end{array}$ & $\begin{array}{c}\varepsilon_{r} / \varepsilon_{a} \\
\varepsilon_{a}=10 \%\end{array}$ \\
\hline \multirow{8}{*}{$\begin{array}{l}\text { Não } \\
\text { reforçado }\end{array}$} & \multirow{4}{*}{$\mathrm{CD}$} & 50 & 0,95 & 10,9 & 0,65 & 0,46 \\
\hline & & 100 & 1,56 & 8,8 & 0,54 & 0,49 \\
\hline & & 200 & 0,87 & 30,7 & 0,73 & 0,53 \\
\hline & & 400 & 1,67 & 31,2 & 0,61 & 0,53 \\
\hline & \multirow{4}{*}{$\mathrm{CU}$} & 50 & 0,50 & 13,5 & - & - \\
\hline & & 100 & 1,45 & 11,9 & - & - \\
\hline & & 200 & 0,90 & 19,3 & - & - \\
\hline & & 400 & 0,80 & 39,3 & - & - \\
\hline
\end{tabular}


Tabela 5.16. $\mathrm{E}_{50}$ e $\varepsilon_{\mathrm{r}} / \varepsilon_{\mathrm{a}}-$ reforçado $(\mathrm{RMAu})$

Rejeito de Minério de Ouro

\begin{tabular}{|c|c|c|c|c|c|c|}
\hline \multirow{2}{*}{ Tipo } & \multirow{2}{*}{ Ensaio } & \multirow{2}{*}{$\begin{array}{c}\text { Tensão } \\
\text { Confinante } \\
\text { efetiva } \\
(\mathrm{kPa})\end{array}$} & \multicolumn{2}{|c|}{$\begin{array}{c}\text { Módulo de } \\
\text { deformabilidade }\end{array}$} & \multicolumn{2}{|c|}{$\begin{array}{c}\text { Relação de } \\
\text { deformações }\end{array}$} \\
\hline & & & $\begin{array}{c}\varepsilon_{\mathrm{a}} \\
(\%)\end{array}$ & $\begin{array}{c}\mathrm{E}_{50} \\
(\mathrm{MPa})\end{array}$ & $\begin{array}{c}\varepsilon_{\mathrm{r}} / \varepsilon_{\mathrm{a}} \\
\varepsilon_{\mathrm{a}}=1 \%\end{array}$ & $\begin{array}{c}\varepsilon_{r} / \varepsilon_{a} \\
\varepsilon_{a}=10 \%\end{array}$ \\
\hline \multirow{8}{*}{$\begin{array}{c}\text { Não } \\
\text { reforçado }\end{array}$} & \multirow{4}{*}{ CD } & 50 & 1,65 & 11,0 & 0,59 & 0,48 \\
\hline & & 100 & 2,45 & 10,8 & 0,61 & 0,55 \\
\hline & & 200 & 1,95 & 25,4 & 0,68 & 0,59 \\
\hline & & 400 & 2,45 & 29,2 & 0,76 & 0,62 \\
\hline & \multirow{4}{*}{$\mathrm{CU}$} & 50 & 2,60 & 5,8 & - & - \\
\hline & & 100 & 4,40 & 5,0 & - & - \\
\hline & & 200 & 2,55 & 10,8 & - & - \\
\hline & & 400 & 2,25 & 25,1 & - & - \\
\hline
\end{tabular}

$\mathrm{Na}$ condição não reforçado drenada, o módulo de deformabilidade estabiliza em tensões altas, enquanto reforçado, continua aumentando com tendência a superar o valor não reforçado. Na condição não drenada, o incremento do módulo de deformabilidade com o aumento da tensão efetiva de confinamento é quase paralelo para os casos não reforçado e reforçado. Todos os valores do $\mathrm{E}_{50}$ são maiores no caso não reforçado mostrando que a fibra reduz o módulo de deformabilidade.

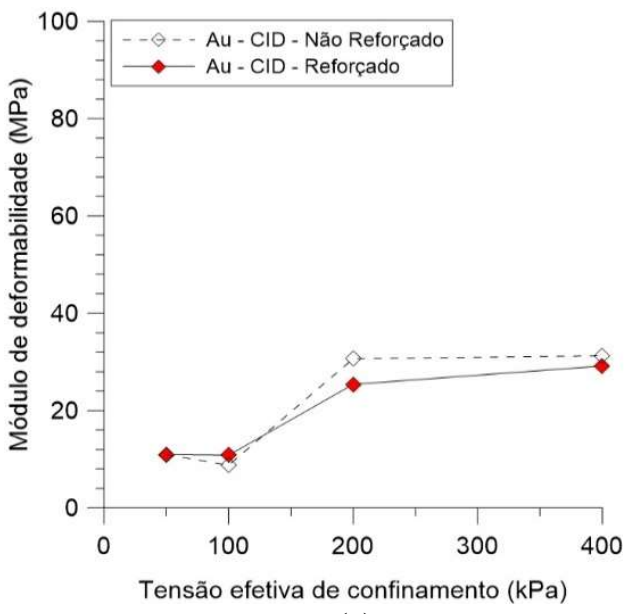

(a)

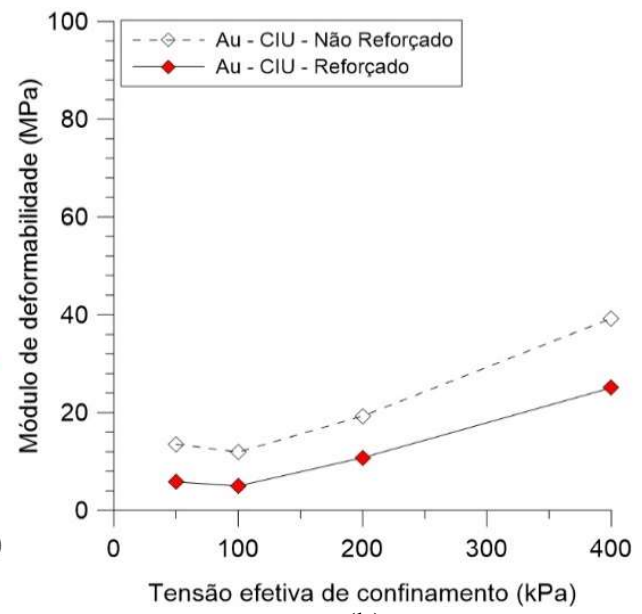

(b)

Figura 5.25. Módulo de deformabilidade (RMAu)

(a) drenado (b) não drenado

A Figura 5.26 mostra a variação da relação de deformações com o aumento da tensão efetiva de confinamento. Para realizar uma comparação com o caso reforçado, as Figuras 5.26(a) e 5.26(b) mostram a evolução da relação antes e depois da ruptura utilizando como padrão as percentagens de 1\% e 10\% de deformação axial. 
A relação de deformações, antes da tensão desviadora de pico, não mostra uma correlação entre as tensões efetivas de confinamento, enquanto o rejeito reforçado exibe um aumento uniforme do coeficiente, antes e depois da ruptura.

Após a ruptura, o rejeito de minério de ouro não reforçado tem uma relação de deformações que aumenta com o incremento da tensão efetiva de confinamento, sendo sempre o caso reforçado que apresenta um valor de relação maior, portanto fibras beneficiam o incremento das deformações radiais ou laterais.

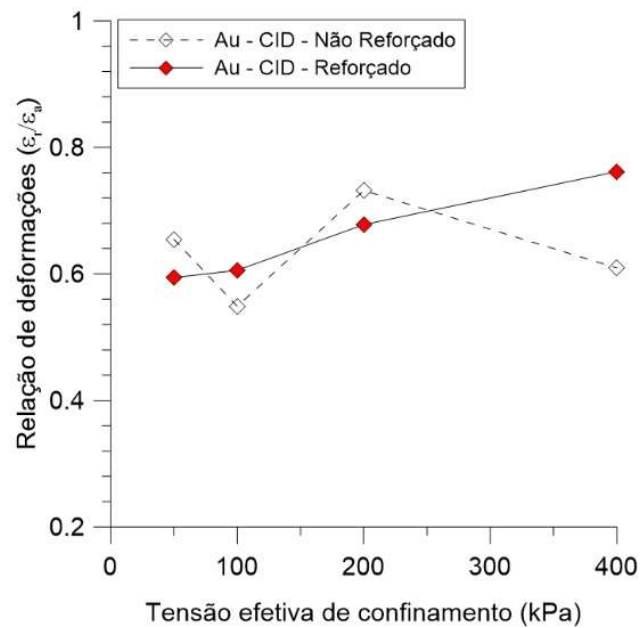

(a)

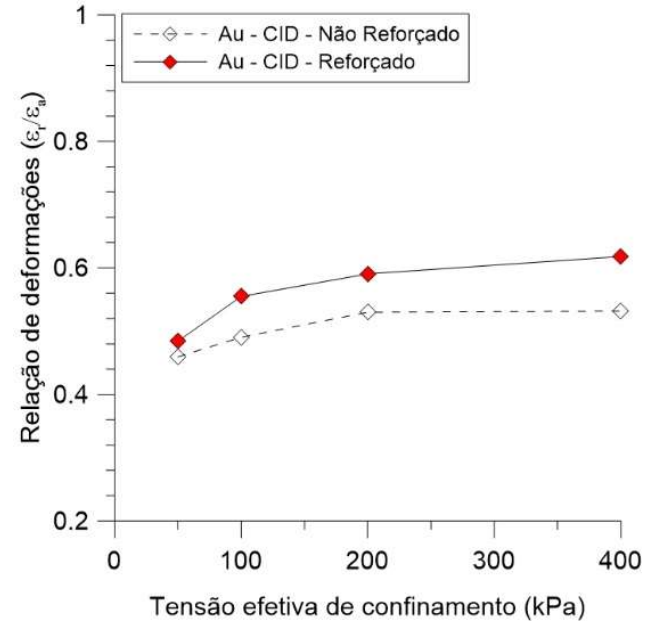

(b)

Figura 5.26. Relação de deformações (RMAu)

(a) $\varepsilon a=1 \%$ (a) $\varepsilon a=10 \%$

As fibras trabalham em tração, portanto, o aporte das fibras se encontra na capacidade de absorver as tensões de tração geradas dentro da matriz, por isso o entrosamento na estrutura dos rejeitos é importante, porque quanto maior seja o entrosamento, as fibras ficarão presas entre os grãos de rejeito e absorverão maiores tensões de tração transmitidas pelo contato de grãos. O rejeito de minério de ferro e ouro são de matriz granular e fina, respectivamente, por conseguinte, entrosamento de grãos somente aparece no rejeito de minério de ferro.

$\mathrm{Na}$ Figura 5.23(b), nota-se que a relação de deformações da matriz granular reforçada é menor do que não reforçada, isto indica que as fibras reduzem as deformações radiais.

Na Figura 5.26(b), o caso é diferente, as fibras incrementam a relação de deformações, mostrando que incrementam as deformações radiais, não existe entrosamento porque neste caso, as fibras se encontram "envolvidas" por partículas mais finas. Segundo as Figuras 5.1(c) e 5.6(c), o comportamento volumétrico 
depois da ruptura dos rejeitos de ferro e ouro não reforçados é dilatante, mas quando a fibra é adicionada, nota-se nas Figuras 5.2(c) e 5.7(c), o comportamento volumétrico para o rejeito de minério de ferro torna-se mais dilatante ainda, enquanto para o rejeito de minério de ouro o comportamento volumétrico muda para contrativo. Figuras 5.2(a) e 5.7(a) mostram que o reforço incrementa a capacidade de suportar maiores tensões desviadoras, portanto, a tendência dilatante apresentada inicialmente deveria incrementar, mas observa-se que isto somente acontece no rejeito de minério de ferro. A mudança do comportamento dilatante para contrativo no rejeito de minério de ouro, deve-se que, a matriz reforçada resiste uma maior tensão desviadora, mas como não existe entrosamento na matriz fina, as fibras não seguram a matriz e geram-se maiores deformações radiais, portanto o rejeito de minério de ouro continua-se comprimindo sendo a tendência contrativa.

\subsection{6.}

\section{Comportamento Normalizado q/p' x taxa de dilatância}

A taxa de dilatância é definida pela variação da deformação volumétrica e a variação da deformação distorcional $\left(\delta \varepsilon_{\mathrm{v}} / \delta \varepsilon_{\mathrm{s}}\right)$. A deformação distorcional é $\varepsilon_{\mathrm{s}}=2 / 3\left(\varepsilon_{\mathrm{a}}-\varepsilon_{\mathrm{r}}\right)$, onde $\varepsilon_{\mathrm{a}}$ e $\varepsilon_{\mathrm{r}}$ são as deformações axial e radial, respectivamente.

Segundo o marco teórico desenvolvido por Atkinson (1993), quando é plotada a razão de tensões q/p' em função da taxa de dilatância, no ponto onde a taxa é zero $\left(\delta \varepsilon_{\mathrm{v}} / \delta \varepsilon_{\mathrm{s}}=0\right)$ se cumpre que $\mathrm{q} / \mathrm{p}^{\prime}=\mathrm{M}$, e esta posição representa o ponto do estado crítico. A Figura 5.27 mostra um esquema do espaço q/p' vs. $\delta \varepsilon_{\mathrm{v}} / \delta \varepsilon_{\mathrm{s}}$ onde o material apresenta comportamento de contração ou dilatante se os valores de $\delta \varepsilon_{\mathrm{v}} / \delta \varepsilon_{\mathrm{s}}$ são positivos ou negativos, respectivamente.

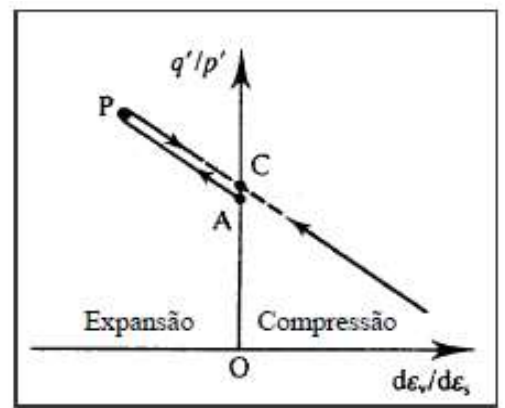

Figura 5.27. Relação entre q/p' e a taxa de dilatação (Atkinson, 1993)

As Figuras 5.28 e 5.29 mostram a razão de tensões q/p' em função da taxa de dilatância $\delta \varepsilon_{\mathrm{v}} / \delta \varepsilon_{\mathrm{s}}$ do rejeito de minério de ferro e ouro, respectivamente. 
Nas Figuras 5.28(a) e (b), verifica-se a tendência dilatante do rejeito de ferro não reforçado e reforçado, respectivamente, para todas as tensões efetivas de confinamento. $\mathrm{O}$ valor de $\mathrm{M}$ obtido no item 5.2.3, ao qual corresponde um ângulo de atrito crítico de $33,8^{\circ}$, também é colocado para verificar que a mudança de comportamento volumétrico passa por esse ponto crítico.

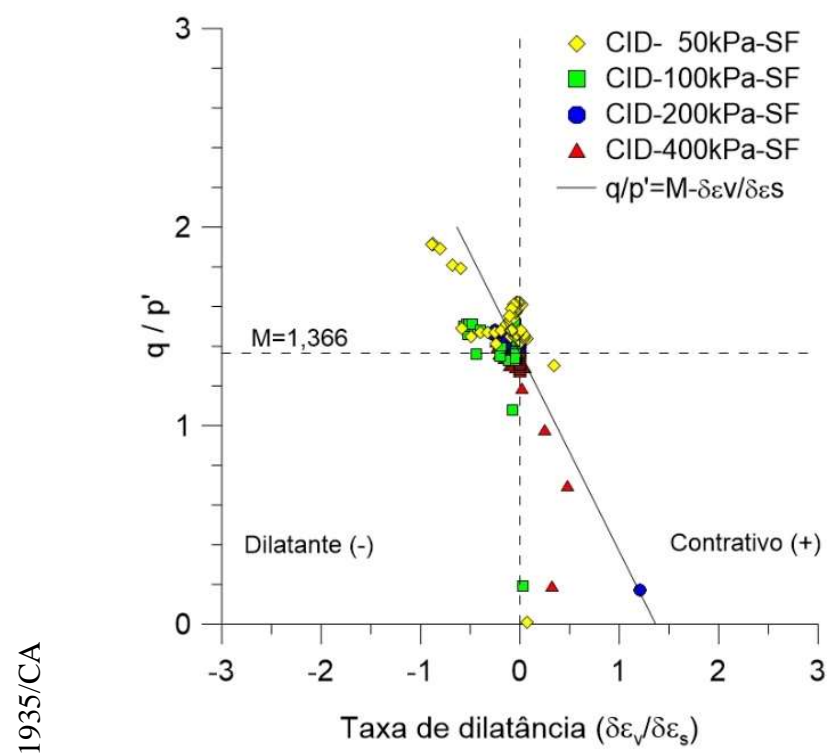

(a)

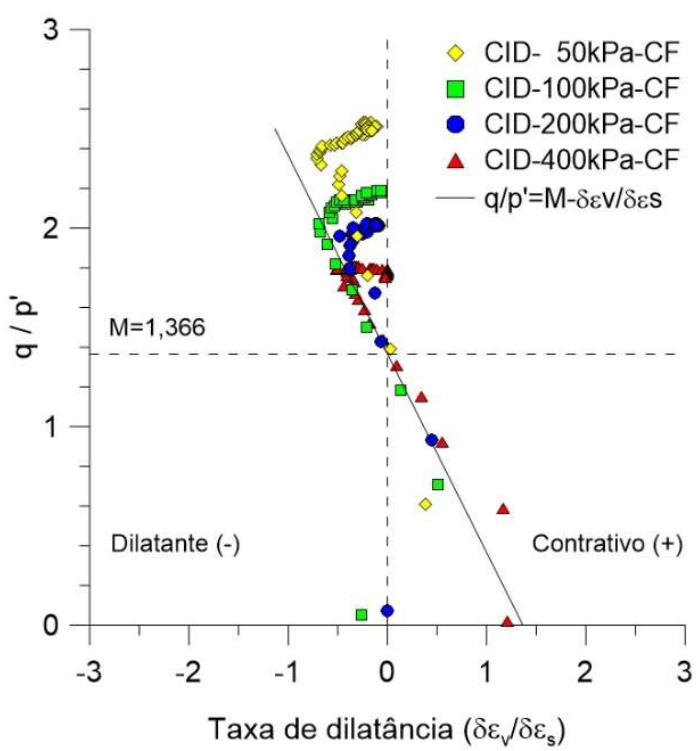

(b)

Figura 5.28. Comportamento normalizado q/p' vs. taxa de dilatação (RMFe) (a) não reforçado (b) reforçado

Rejeito de minério de ferro

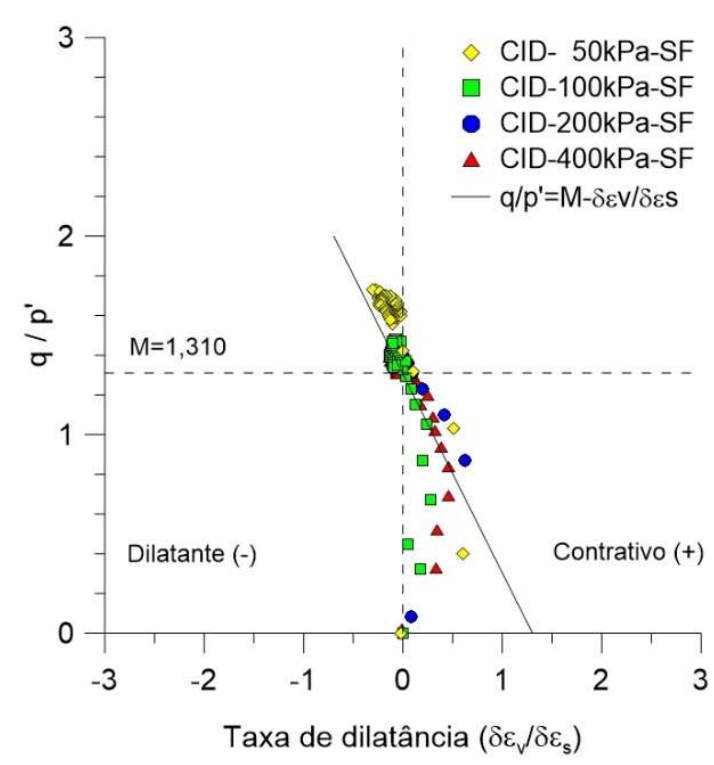

(a)

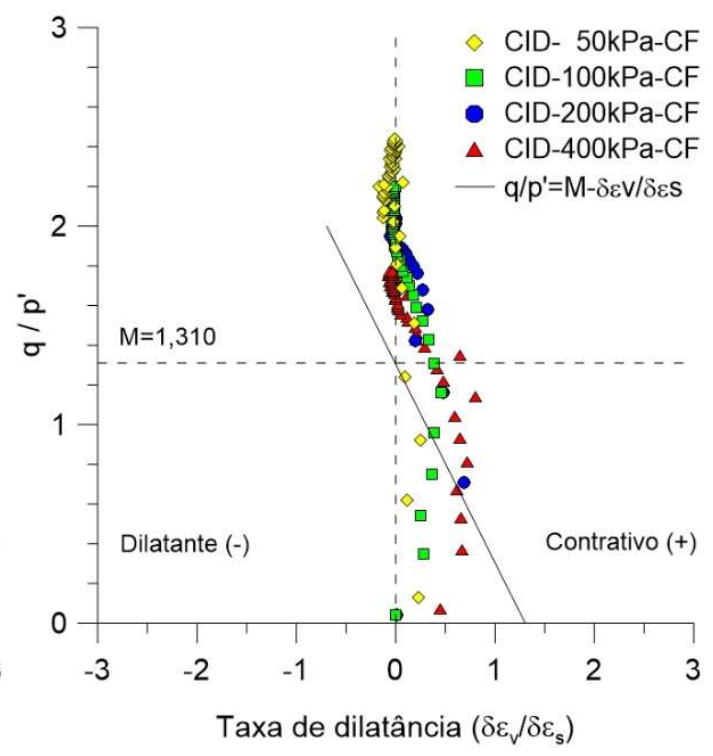

(b)

Figura 5.29. Comportamento normalizado q/p' vs. taxa de dilatação (RMAu) (a) não reforçado (b) reforçado Rejeito de minério de ouro 
Na Figura 5.29(a) verifica-se que os pontos cruzam a taxa de dilatância zero em $\mathrm{M}=1,310$ na linha de estado crítico calculada no item 5.2.3, ao qual corresponde um ângulo de atrito crítico de 32,5\%, em contraste na Figura 5.29(b), verifica-se que os pontos não cruzam a taxa de dilatância zero no ponto $\mathrm{M}$.

A inclinação da envoltória do estado crítico $M$ relaciona razoavelmente bem a razão de tensões e dilatância, dada pela equação (5.3).

$\frac{q}{p^{\prime}}=M-\frac{\delta \varepsilon_{v}}{\delta \varepsilon_{s}}$

Observa-se que, em ambos os tipos de rejeitos de minério, a adição de fibra aumenta a razão de tensões q/p', principalmente para tensões efetivas médias baixas, portanto os valores obtidos pela equação 5.3 são inferiores aos observados pelos rejeitos reforçados. Heineck (2002) e Casagrande (2005) observaram este comportamento mas em solos residuais de arenito reforçados com fibras.

$\mathrm{Na}$ Figura 5.29(b) nota-se a supressão do comportamento contrativo para todos os níveis de tensão efetiva de confinamento.

\subsection{7.}

\section{Análise da Rigidez}

Para avaliar mudanças na rigidez do rejeito pela adição das fibras, os dados dos ensaios triaxiais foram analisados em termos do módulo de deformação tangente, plotados versus o logaritmo das deformações distorcionais $\left(\varepsilon_{\mathrm{s}}\right)$.

Considerando que o rejeito tem um comportamento isotrópico, a rigidez é expressa pelo módulo cisalhante $(\mathrm{G})$, obtido pela equação (5.4):

$$
G=\frac{\delta q}{3 \delta \varepsilon_{s}}
$$

A avaliação da rigidez nos rejeitos não reforçados e reforçados foi feita com o objetivo de analisar a influência da adição de fibras, não sendo dada atenção à avaliação da plastificação do material.

Atkinson \& Bransby (1978) descreveram a relação típica entre o módulo cisalhante e as deformações distorcionais para solos normalmente adensados e préadensados, indicando três regiões onde o comportamento é diferente. A Figura 5.30 apresenta estes comportamentos, separados segundo a magnitude das deformações. 


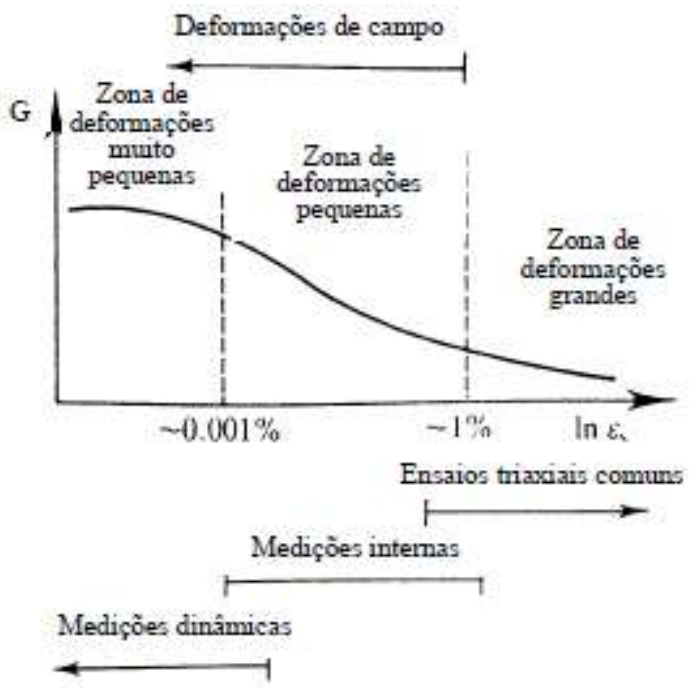

Figura 5.30. Rigidez dos solos comparados com testes de laboratório (Atkinson \& Bransby, 1978)

Deformações muito pequenas, usualmente menores à ordem de $0,001 \%$, produzem rigidezes aproximadamente constantes com um comportamento tensãodeformação linear, diferente ao comportamento intermediário de deformações pequenas, entre 0,001 e $1 \%$, onde a rigidez muda rapidamente com a tensão, mostrando um comportamento não linear. No caso de grandes deformações, dentro da faixa dos ensaios triaxiais com deformações distorcionais maiores que $1 \%$, o comportamento é elasto-plástico.

Os resultados mostram concordância na forma da curva G: $\log \varepsilon_{\mathrm{s}}$ segundo o padrão apresentado na literatura (Cuccolvillo \& Coop, 1997; Montardo, 1999; Fehuerharmel, 2000; Casagrande, 2005) uma parte elástico-linear seguida de uma redução da rigidez com o aumento da deformação distorcional.

A literatura mostra resultados contrários sobre a influência da fibra, Montardo (1999) observou que não exercem efeito na rigidez de areias, enquanto Feuerharmel (2000) e Casagrande (2005), verificaram que a rigidez possui uma redução, mas é insignificante.

Ensaios drenados, na Figura 5.31, e não drenados, na Figura 5.32, mostram que o módulo cisalhante do rejeito de ferro foi zero entre 2-3\% de deformação axial, e com reforço foi zero entre $5-9 \%$.

No rejeito de ouro, na Figura 5.33, somente se alcançou o zero na condição drenada em 3\%, sendo o mínimo valor reforçado alcançado em $8 \%$. Na condição não drenada, na Figura 5.34, nenhum caso reduziu até zero, mas os mínimos situaram-se em 10 e $20 \%$, não reforçado e reforçado. 


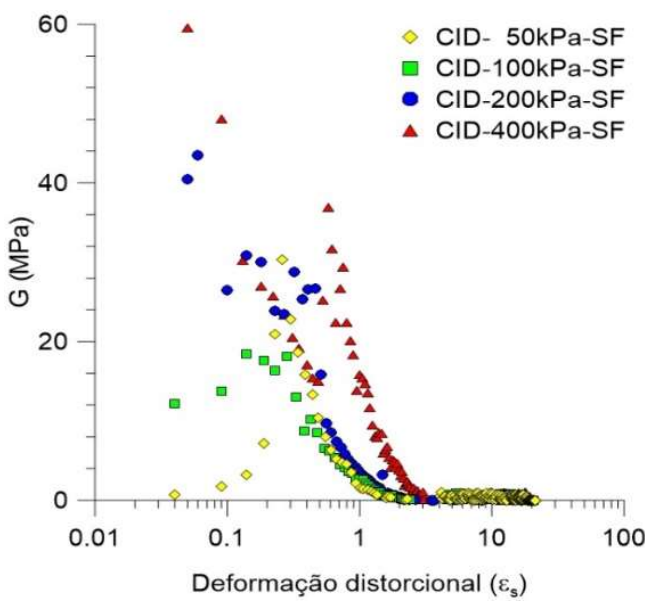

(a)

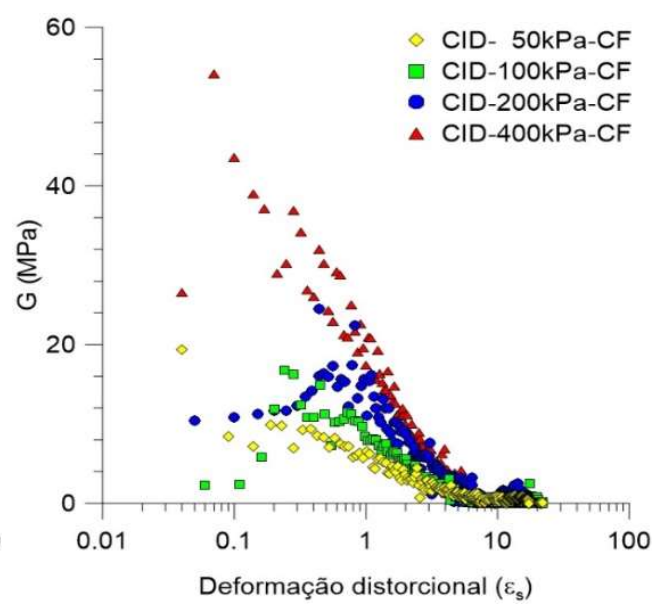

(b)

Figura 5.31. Módulo cisalhante drenado (RMFe)

(a) não reforçado (b) reforçado

Rejeito de minério de ferro

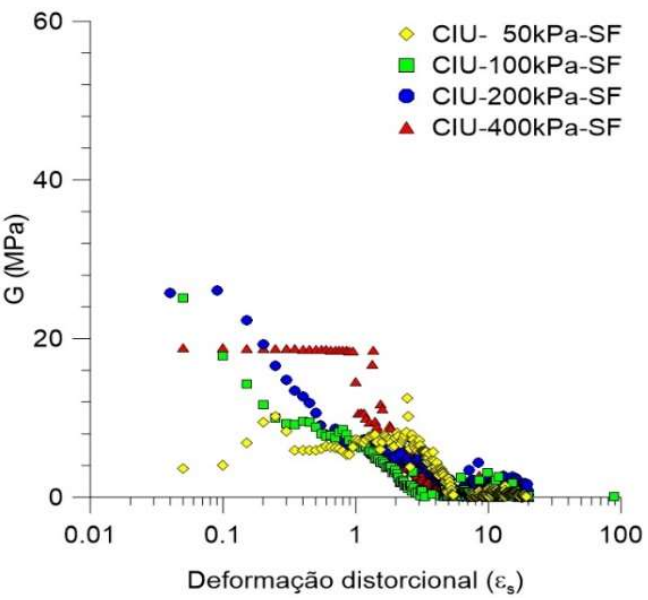

(a)

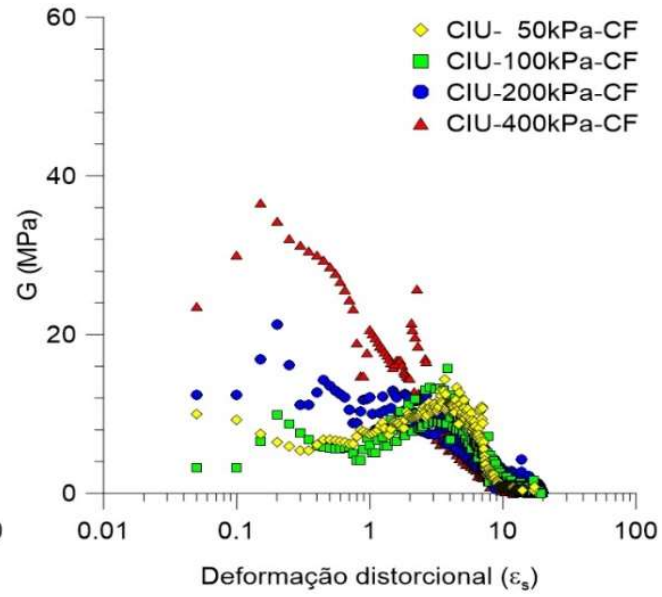

(b)

Figura 5.32. Módulo cisalhante não drenado (RMFe)

(a) não reforçado (b) reforçado

Rejeito de minério de ferro

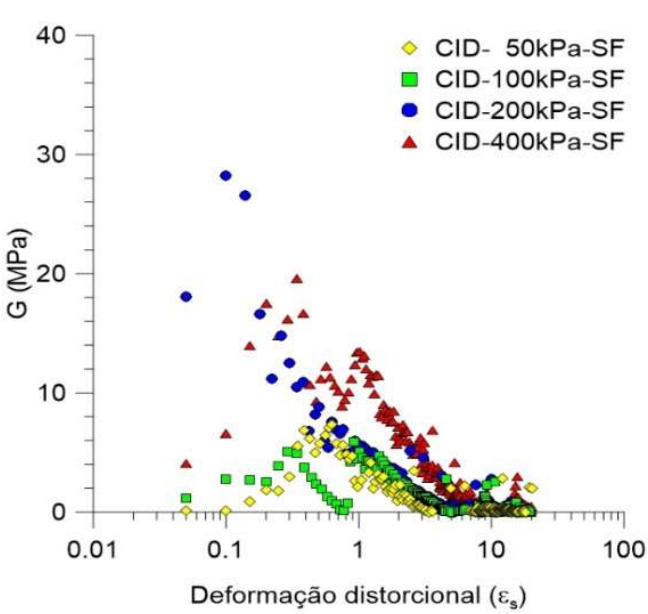

(a)

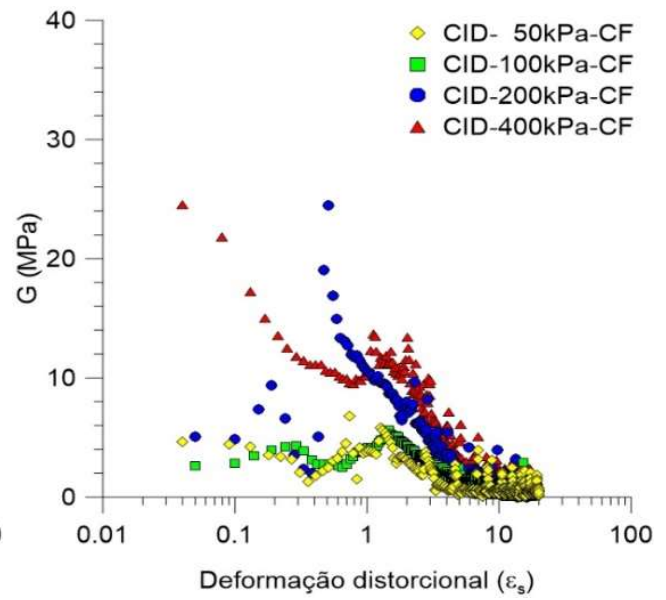

(b)

Figura 5.33. Módulo cisalhante drenado (RMAu)

(a) não reforçado (b) reforçado

Rejeito de minério de ouro 


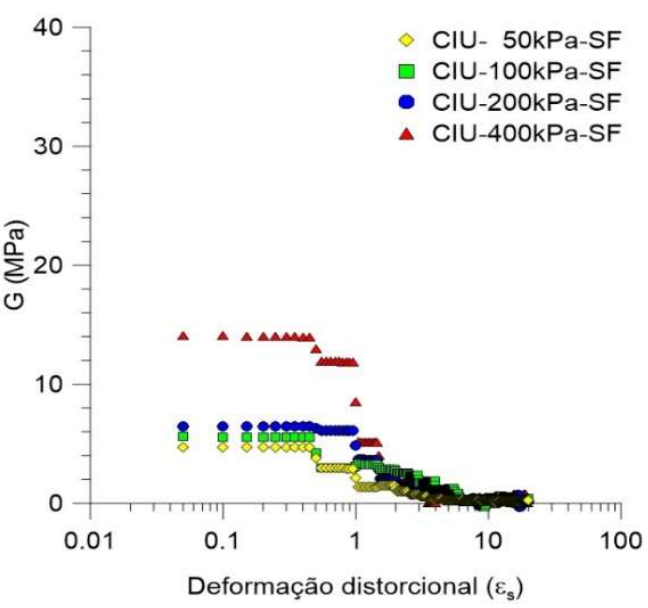

(a)

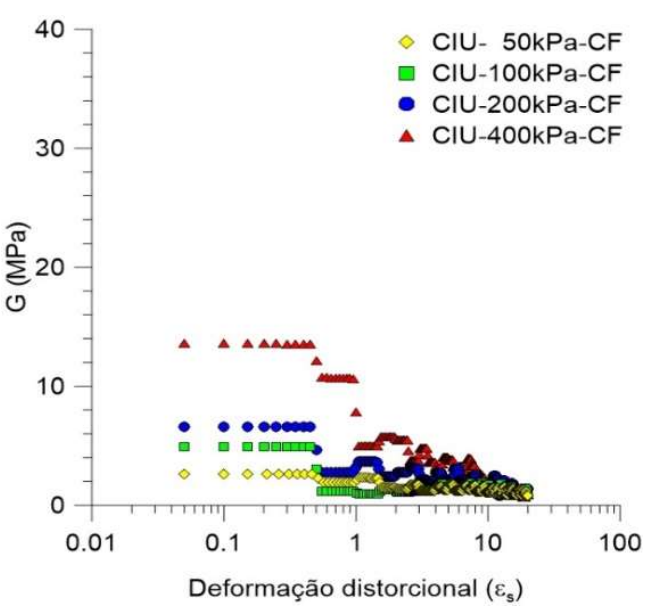

(b)

Figura 5.34. Módulo cisalhante não drenado (RMAu)

(a) não reforçado (b) reforçado

Rejeito de minério de ouro

\subsection{8.}

\section{Energia de Deformação Absorvida}

A tenacidade é a energia de deformação total que é capaz de absorver ou acumular um material antes de alcançar a ruptura. Matematicamente, a quantidade de energia acumulada é denominada Energia de deformação $\left(E_{\text {def }}\right)$ pode ser calculada pela área abaixo da curva tensão vs. deformação que neste estudo foi avaliada até uma deformação de $20 \%$.

Nos rejeitos de minério de ferro e ouro, as Figuras 5.35, 5.36 e 5.37, 5.38 apresentam as curvas de energia de deformação absorvida nas condições drenada e não drenada respectivamente.

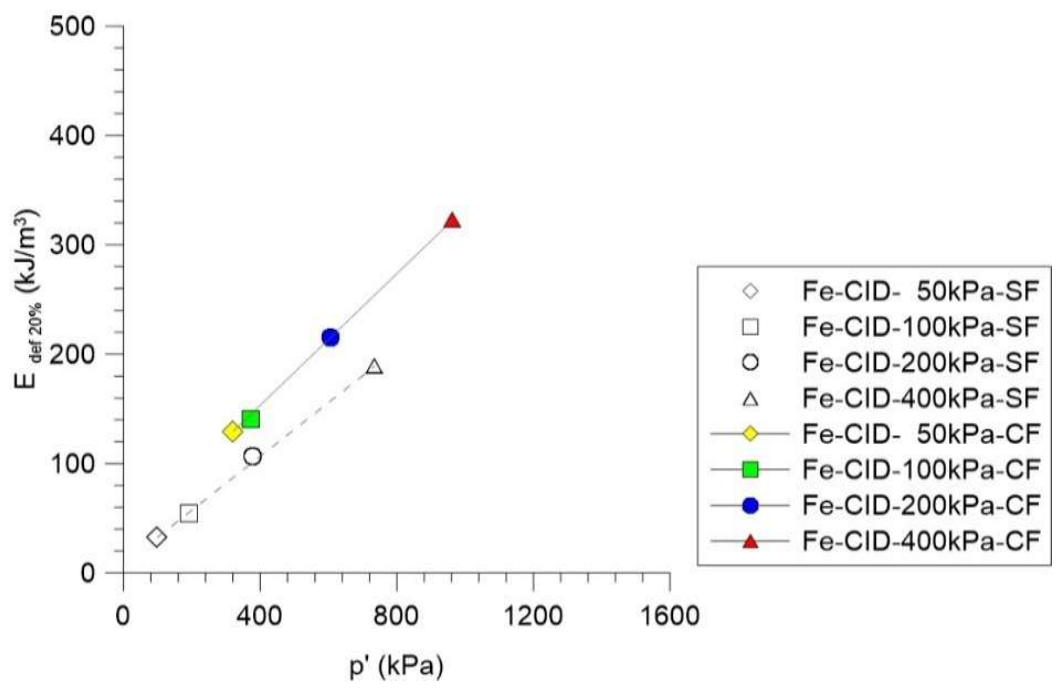

Figura 5.35. Energia de deformação absorvida CD ao $20 \%$ de $\varepsilon_{\mathrm{a}}$ (RMFe)

Rejeito de minério de ferro 


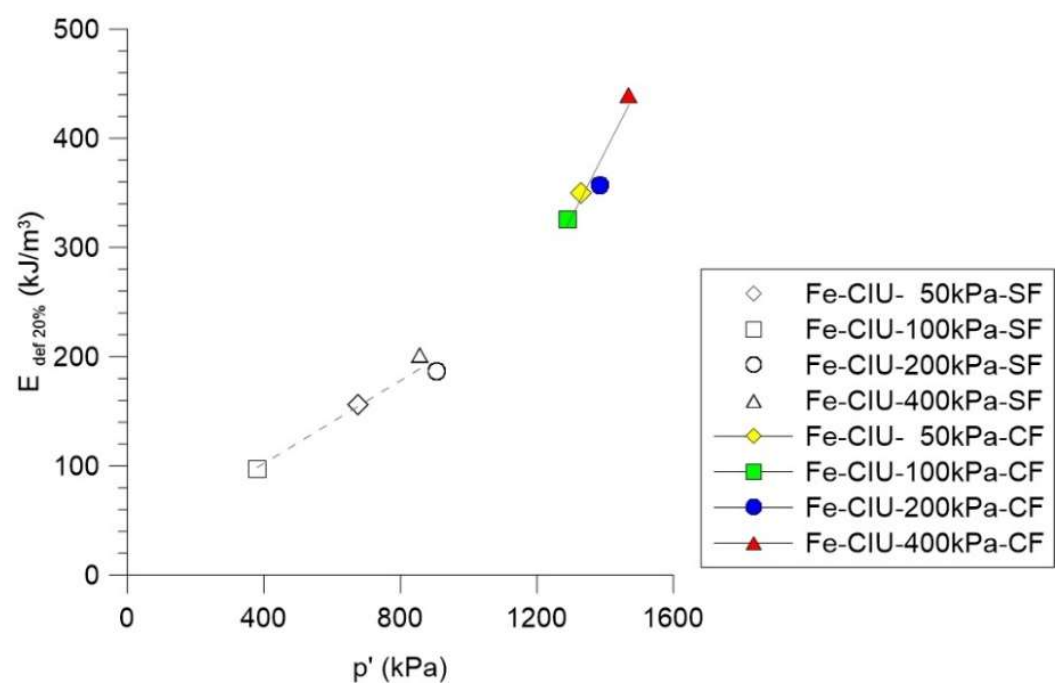

Figura 5.36. Energia de deformação absorvida CU ao $20 \%$ de $\varepsilon_{\mathrm{a}}(\mathrm{RMFe})$

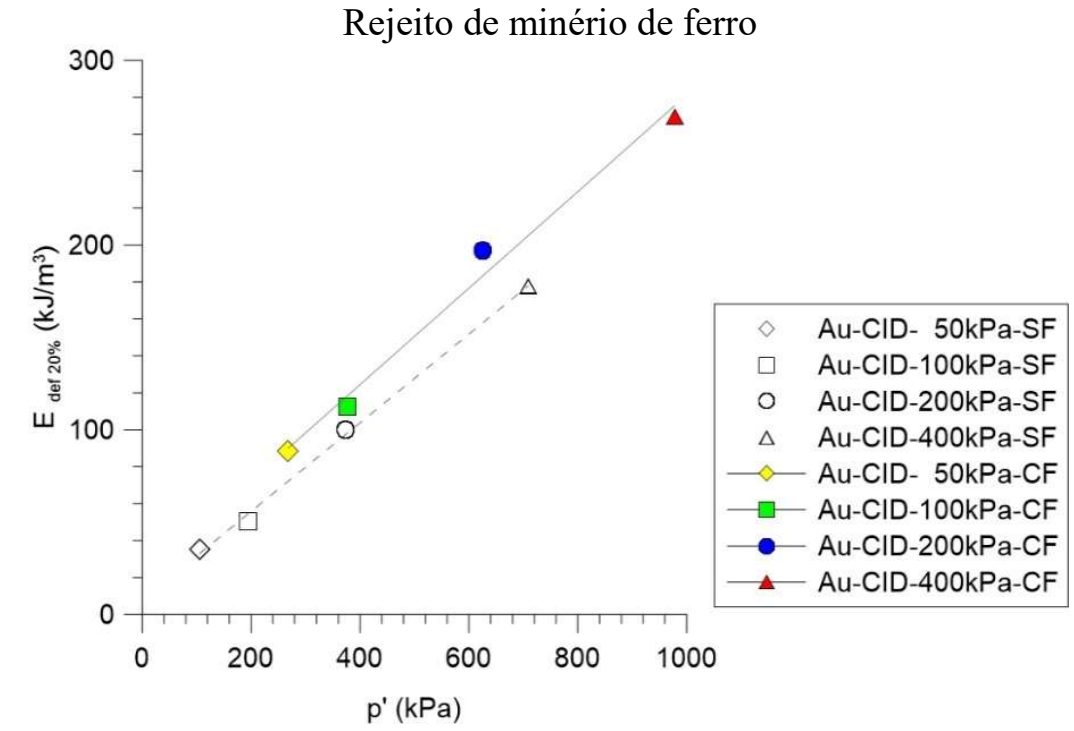

Figura 5.37. Energia de deformação absorvida CD ao $20 \%$ de $\varepsilon_{\mathrm{a}}(\mathrm{RMAu})$

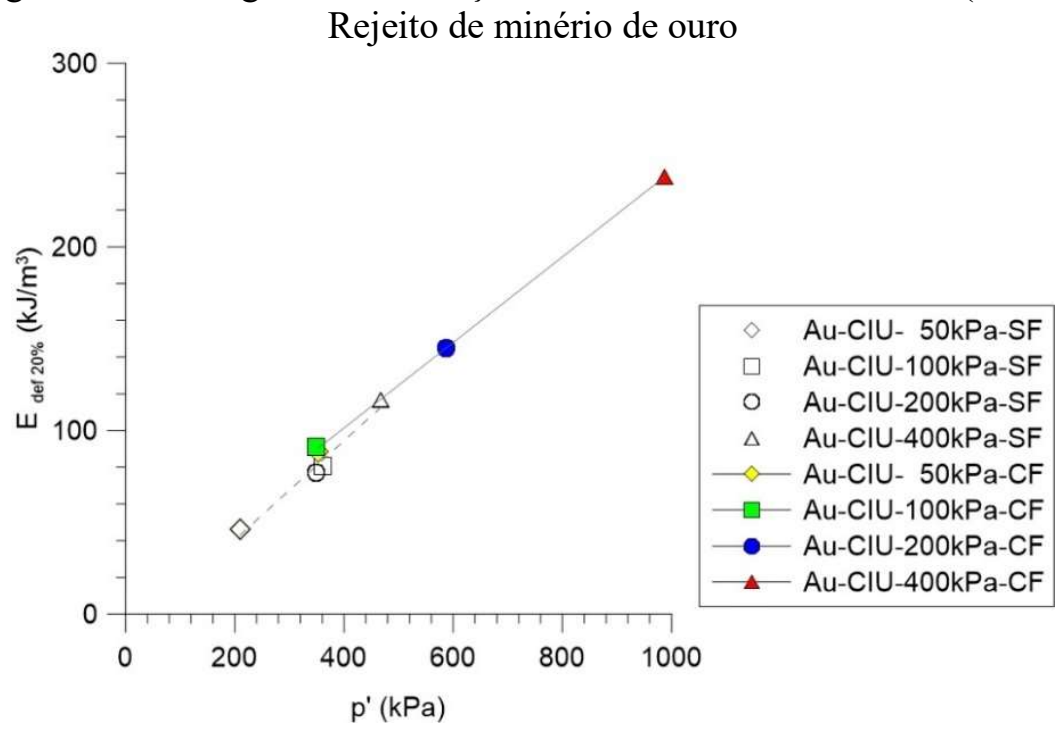

Figura 5.38. Energia de deformação absorvida CU ao $20 \%$ de $\varepsilon_{\mathrm{a}}(\mathrm{RMAu})$ Rejeito de minério de ouro não drenado 
Observa-se um aumento linear da energia de deformação acumulada com o incremento das tensões efetivas médias na condição drenada e não drenada, sendo maior o incremento no rejeito reforçado, mostrando que fibras influem na tenacidade dos rejeitos em todos os níveis de tensão.

No rejeito de minério de ferro reforçado nota-se, na condição não drenada da Figura 5.36, um maior acúmulo de energia de deformação do que na condição drenada reforçada, o acréscimo é dado pela redução de poropressão que gera um acréscimo maior na tensão efetiva média. Na Figura 5.38, no caso do rejeito de minério de ouro, não se percebe este grande acúmulo de energia, porque a redução da poropressão é muito menor do que no rejeito de minério de ferro.

\subsection{9.}

\section{Variação do excesso de poropressão}

A análise de poropressão merece especial atenção pois nos itens anteriores notou-se que o aumento ou redução influi diretamente no incremento da energia de deformação e consequentemente nas tensões médias efetivas sobretudo nos rejeitos de minério reforçados.

No rejeito de minério de ferro, as Figuras 5.3(f) e 5.4(f) mostram a variação do excesso de poropressão normalizada pela tensão efetiva de confinamento versus a deformação axial nas amostras não reforçadas e reforçadas, respectivamente.

Na Figura 5.3(f), no início do carregamento, o rejeito não reforçado alcança um valor máximo de 0,43 em deformações entre 0,20 e 1,45\%, nos ensaios drenados neste intervalo de deformação observou-se um comportamento volumétrico contrativo, na transição ao comportamento dilatante percebe-se uma considerável queda de poropressão normalizada até chegar a um ponto no qual a redução é menor até o fim do ensaio. Este comportamento esperado de mudança contrativa a dilatante está associada ao grau de compactação do rejeito de minério de ferro que possui uma densidade média a densa, sendo a mudança volumétrica mais visível em tensões menores de consolidação. Nota-se que a tendência dominante na matriz não reforçada é dilatante.

No caso do rejeito reforçado, o valor máximo da variação do excesso de poropressão normalizada corresponde a 0,56 , maior do que no caso não reforçado, entre 0,50 e $1,14 \%$ de deformação, isto indica que no início do ensaio, o reforço favorece à tendência contrativa até certo ponto porque depois prevalece a tendência 
dilatante da matriz. Quando o rejeito reforçado passa à tendência dilatante nota-se uma maior redução da variação do excesso de poropressão normalizada comparado com o caso não reforçado.

O efeito do acréscimo do excesso da poropressão pela presença de fibras pode ser explicado pelo fato de que as fibras trabalham sob tração, portanto com o incremento da tensão desviadora as fibras distribuídas no entrosamento do rejeito se esticam, não obstante, como as condições são não drenadas e não existem mudanças de volume, as fibras geram um confinamento adicional ao interior do rejeito causando um efeito de compressão que favorece a tendência contrativa, logo, o excesso de poropressão aumenta nesse período, mas como os ensaios drenados mostraram que no rejeito não reforçado prevalece a tendência dilatante, o efeito da fibra acaba sendo superado, quando sobrevém o comportamento dilatante o excesso de poropressão diminui, tornando o efeito de confinamento das fibras esticadas em um acréscimo para a tensão efetiva média. As curvas tensão desviadora normalizada pela tensão efetiva de confinamento vs. deformação das Figuras 5.3(e) e 5.4(e), mostram que o efeito da fibra é maior quanto a tensão efetiva de confinamento é menor, e é relativamente suprimida quando incrementa.

Nota-se que no rejeito de minério de ferro existem duas variáveis que determinam a tendência da mudança de volume: a tendência contrativa da fibra e a tendência dilatante da matriz. A Figura 5.39 apresenta a taxa de variação do excesso de poropressão vs. deformação distorcional em escala sem logarítmica para poder visualizar a variação em deformações muito pequenas.

Nota-se na Figura 5.39, que existem dois pontos onde a taxa da variação do excesso de poropressão normalizada $\left(\delta\left(\Delta \mathrm{u} / \sigma^{\prime}{ }_{c}\right) / \delta \varepsilon_{\mathrm{s}}=0\right)$ é zero, no primeiro e segundo ponto se alcança o máximo e mínimo valor da poropressão, respectivamente. Após o primeiro ponto, a queda considerável do valor máximo de poropressão indica o começo da tendência dilatante antes da ruptura e a partir do segundo ponto, a tendência dilatante se reduz pela estabilização de poropressão.

No rejeito de minério de ferro não reforçado observa-se, que entre 0,20 e $1,45 \%$ todos os ensaios atingiram o valor máximo de poropressão, enquanto no rejeito reforçado, a poropressão máxima se alcança entre 0,50 e 1,15\%.

Observa-se uma maior queda da taxa na Figura 5.39(b), verificando que a tendência dilatante é maior no rejeito reforçado, sobretudo em tensões efetivas médias baixas. 
$\mathrm{Na}$ condição reforçada e não reforçada existe uma supressão da tendência dilatante e as taxas de variação tendem à estabilidade no ponto zero.

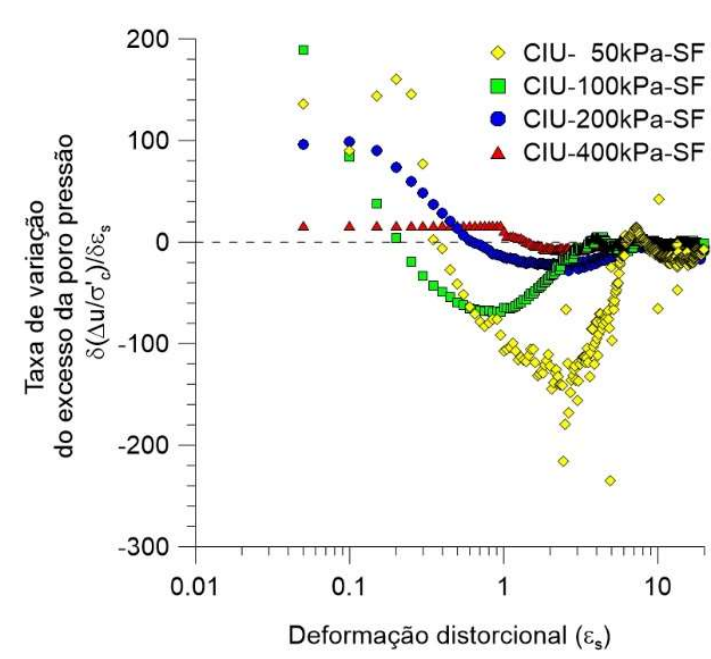

(a)

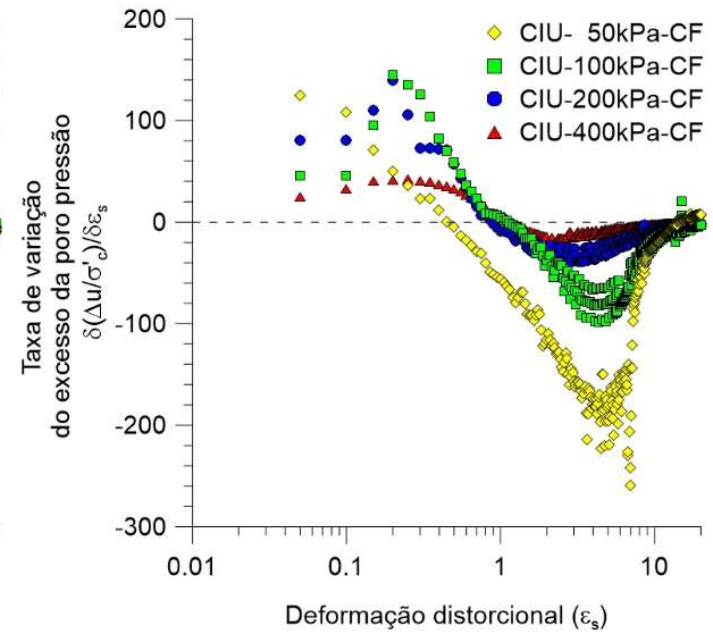

(b)

Figura 5.39. Taxa de variação do excesso de poropressão vs. $\varepsilon_{\mathrm{s}}(\mathrm{RMFe})$ Rejeito de minério de ferro

(a) não reforçado (b) reforçado

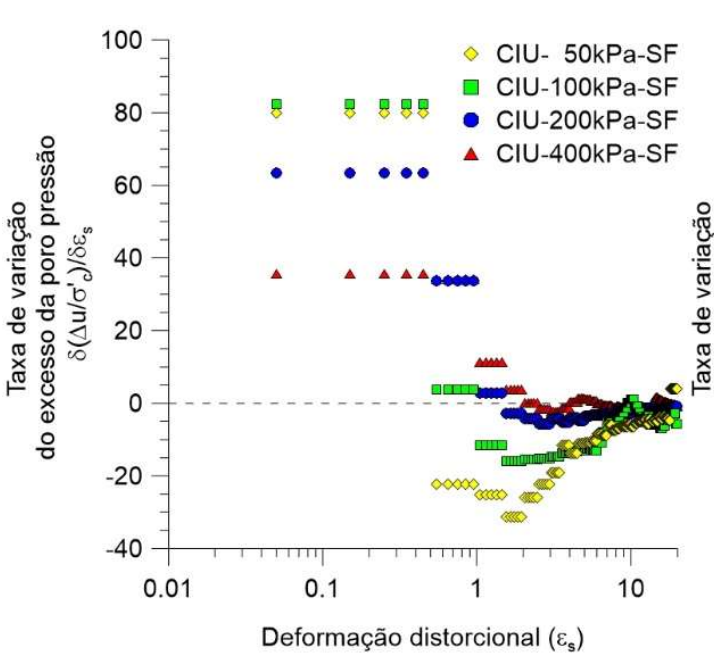

(a)

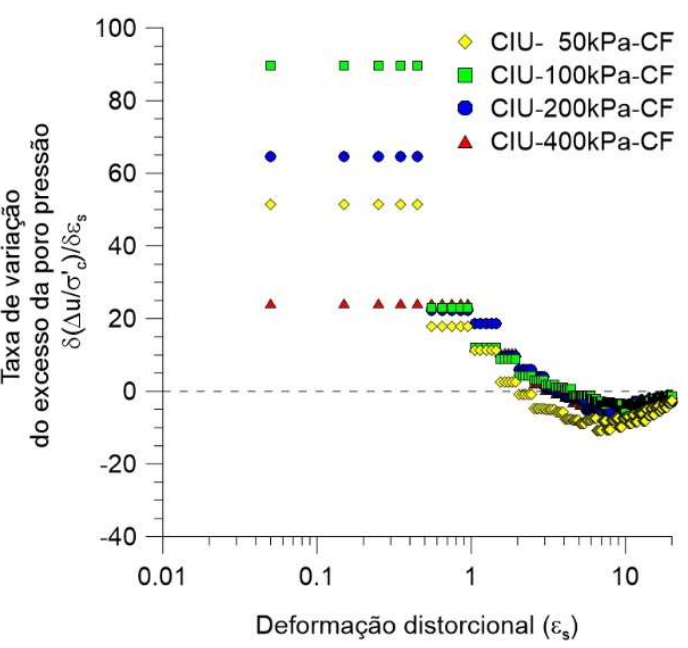

(b)

Figura 5.40. Taxa de variação do excesso de poropressão vs. $\varepsilon_{\mathrm{s}}$ (RMAu)

Rejeito de minério de ouro

(a) não reforçado (b) reforçado

No rejeito de minério de ouro não reforçado, observa-se que, entre 0,5 e 2,0\%, todos os ensaios atingiram o valor máximo de poropressão, enquanto no rejeito reforçado, a poropressão máxima se alcança entre 2,0 e 4,5\%. Observa-se que adição de fibra suprime a tendência dilatante não reforçada mantendo-se ao final do ensaio perto da taxa de variação zero. A seguir define-se o momento da transformação de fase da tendência contrativa a dilatante em ensaios não drenados. 


\subsubsection{1.}

\section{Linha de Transformação de fase}

A transformação de fase não drenada é aquele estado onde a resposta da areia muda de contrativa a dilatante (Murthy et al., 2007). Essa transição acontece ao longo de uma linha que passa pela origem do espaço q-p', denominando-se como linha de transformação de fase.

Segundo Ishihara et al., (1975), a transformação de fase localiza-se no ponto onde a trajetória de tensões muda a direção no espaço p'-q, ou seja, no ponto onde a trajetória de tensões efetivas média alcança um valor mínimo.

Lade \& Ibsen (1997) notaram que o estado de tensões correspondente à máxima poropressão acontece levemente depois da transformação de fase. É importante determinar a localização da linha de transformação de fase porque indica o ponto onde a areia começa a ser instável (Lade, 1995).

A Figura 5.41, adaptada de Lade \& Ibsen (1997), mostra um esquema da linha de transformação de fase em um ensaio não drenado.

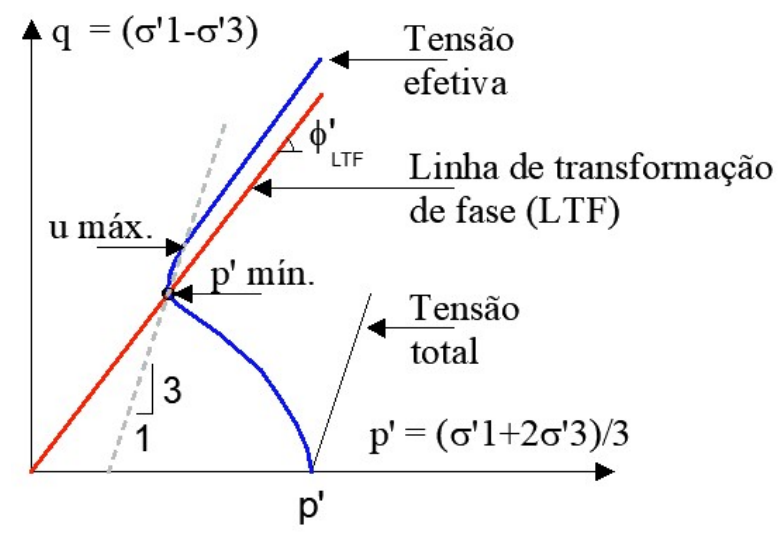

Figura 5.41. Esquema da posição da Linha de transformação de fase

Nas Figuras 5.3 (b) e 5.4 (b), é possível observar que existem trajetórias que são totalmente orientadas para a direita mostrando que a tensão efetiva média sempre aumenta. Neste caso, para obter uma aproximação do ponto de transformação de fase usa-se o ponto onde a trajetória muda drasticamente. Com base nestas conclusões, calcula-se o ângulo de atrito mobilizado da linha de transferência de fase mediante sen $\phi^{\prime}=3 \mathrm{M} /(6+\mathrm{M})$ com $\mathrm{M}=\mathrm{q} / \mathrm{p}$ '. A Tabela 5.17 mostra os pontos utilizados para desenhar a linha de transformação de fase no ensaio não drenado no rejeito de minério de ferro. 
Tabela 5.17. Linha de transformação de fase (RMFe)

\begin{tabular}{c|c|c|c|c}
\multicolumn{5}{c}{ Rejeito de Minério de Ferro } \\
\hline \multirow{3}{*}{ Ensaio } & $\begin{array}{c}\text { Tensão } \\
\text { Confinante } \\
\text { efetiva } \\
(\mathrm{kPa})\end{array}$ & $\begin{array}{c}\varepsilon_{\mathrm{a}} \\
(\%)\end{array}$ & $\begin{array}{c}\mathrm{p} \\
(\mathrm{kPa})\end{array}$ & $\begin{array}{c}\mathrm{q} \\
(\mathrm{kPa})\end{array}$ \\
\hline \multirow{4}{*}{$\begin{array}{c}\text { Não } \\
\text { Reforçado }\end{array}$} & 50 & 0,20 & 46,64 & 31,91 \\
\cline { 2 - 5 } & 100 & 0,35 & 134,31 & 159,39 \\
\cline { 2 - 5 } & 200 & 0,50 & 228,19 & 266,10 \\
\cline { 2 - 5 } & 400 & 1,00 & 522,16 & 560,64 \\
\hline \multirow{4}{*}{ Reforçado } & 50 & 0,40 & 66,00 & 86,30 \\
\cline { 2 - 5 } & 100 & 0,55 & 86,03 & 101,99 \\
\cline { 2 - 5 } & 200 & 0,40 & 182,55 & 168,75 \\
\cline { 2 - 5 } & 400 & 0,65 & 503,01 & 577,06 \\
\hline
\end{tabular}

As Figuras 5.42 (a) e (b) mostram as linhas de transformação de fase para o rejeito de minério de ferro não reforçado e reforçado, se obtendo ângulos de atrito na transformação de fase ( $\left.\phi^{\prime}{ }_{\mathrm{LTF}}\right)$ de $27,5^{\circ}$ e $28,3^{\circ}$, respectivamente.

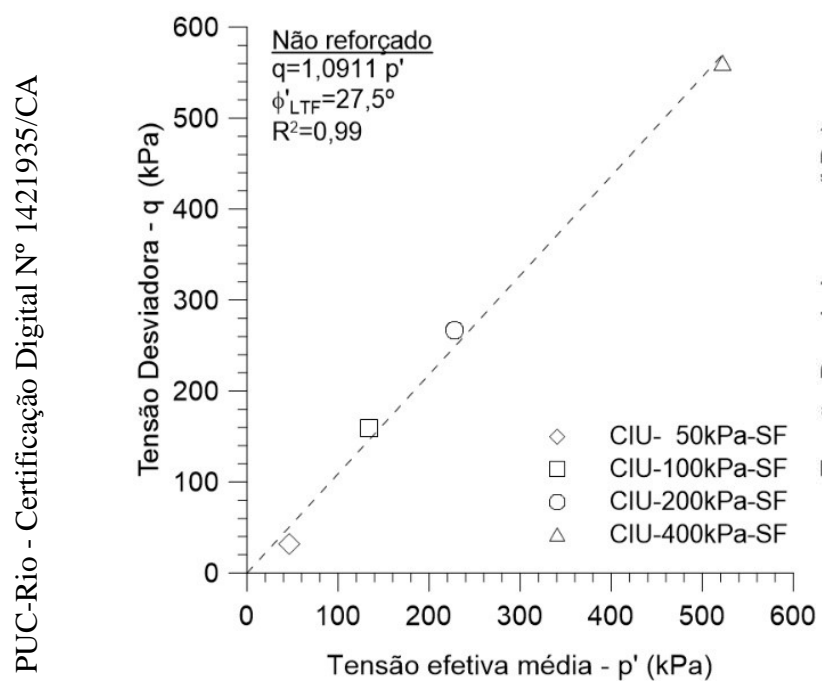

(a)

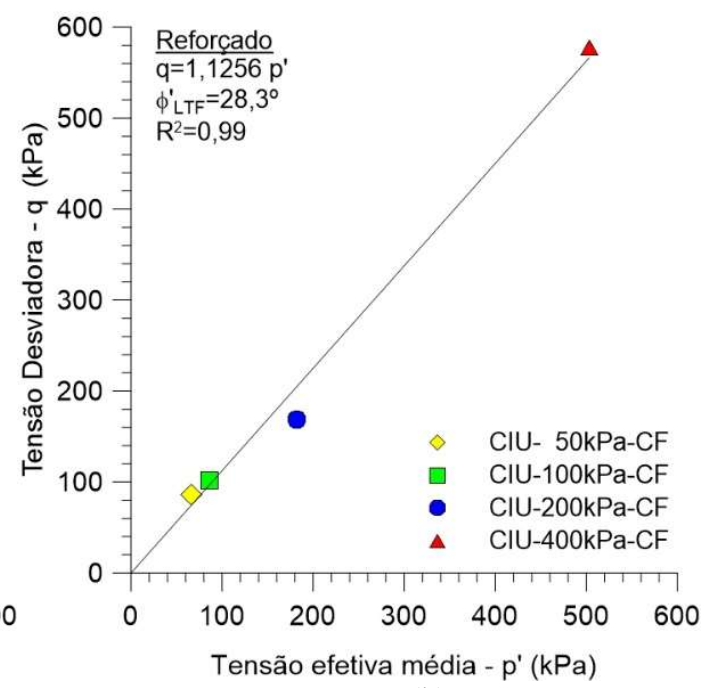

(b)

Figura 5.42. Linha de transformação de fase (RMFe) Rejeito de minério de ferro

(a) não reforçado (b) reforçado

Sitharam et al., (2004) analisaram o comportamento não drenado de uma areia siltosa e mostraram que a tensão efetiva de confinamento tem a maior influência na mudança do comportamento contrativo para dilatante, quanto maior seja a tensão de confinamento mais estável é o material, sendo seus resultados parecidos com as trajetórias de tensão obtidas neste estudo.

A Tabela 5.18 mostra os pontos utilizados para desenhar a linha de transformação de fase no ensaio não drenado no rejeito de minério de ouro. 
Tabela 5.18. Linha de transformação de fase (RMAu)

\begin{tabular}{c|c|c|c|c}
\multicolumn{5}{c}{ Rejeito de Minério de Ouro } \\
\hline \multirow{4}{*}{ Ensaio } & $\begin{array}{c}\text { Tensão } \\
\text { Confinante } \\
\text { efetiva } \\
(\mathrm{kPa})\end{array}$ & $\begin{array}{c}\varepsilon_{\mathrm{a}} \\
(\%)\end{array}$ & $\begin{array}{c}\mathrm{p}^{\prime} \text { min } \\
(\mathrm{kPa})\end{array}$ & $\begin{array}{c}\mathrm{q} \\
(\mathrm{kPa})\end{array}$ \\
\hline \multirow{3}{*}{$\begin{array}{c}\text { Não } \\
\text { Reforçado }\end{array}$} & 50 & 0,50 & 53,47 & 70,42 \\
\cline { 2 - 5 } & 100 & 0,50 & 86,70 & 83,45 \\
\cline { 2 - 5 } & 200 & 1,00 & 165,70 & 188,51 \\
\cline { 2 - 5 } Reforçado & 400 & 1,00 & 390,34 & 389,06 \\
\hline & 50 & 0,50 & 50,77 & 40,81 \\
\cline { 2 - 5 } & 100 & 1,05 & 73,19 & 106,34 \\
\cline { 2 - 5 } & 200 & 1,05 & 159,48 & 194,54 \\
\cline { 2 - 5 } & 400 & 1,50 & 425,12 & 438,92 \\
\hline
\end{tabular}

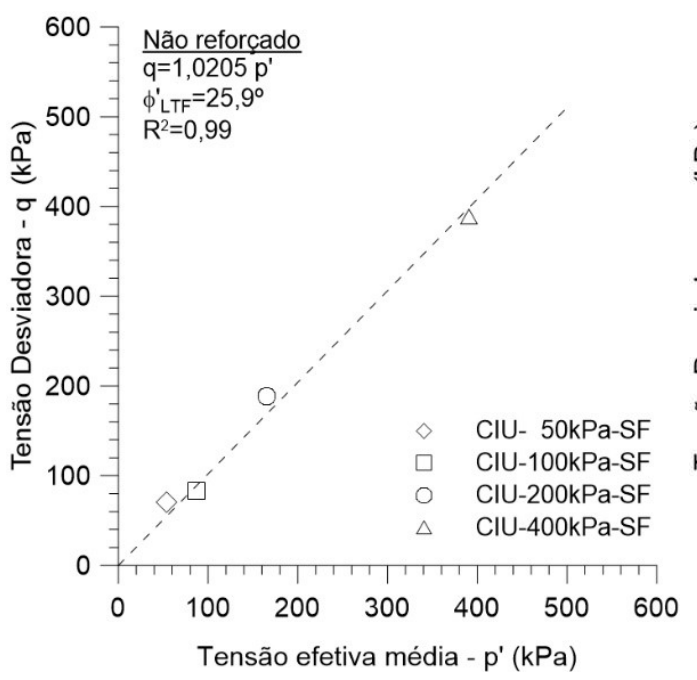

(a)

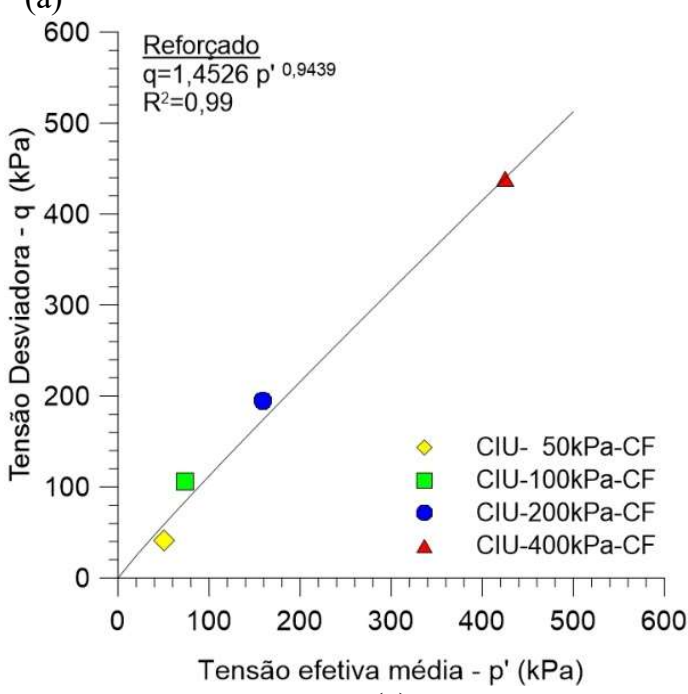

(c)

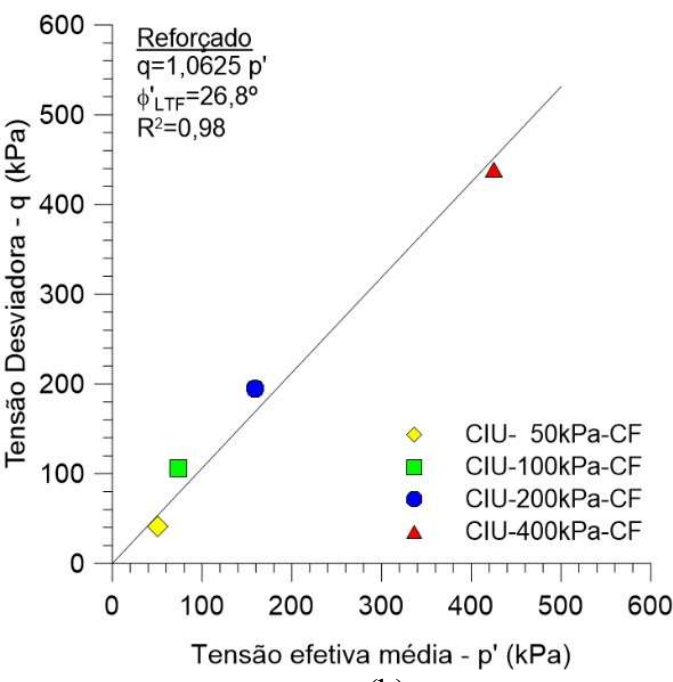

(b)

Figura 5.43. Linha de transformação de fase (RMAu) Rejeito de minério de ouro

(a) não reforçado (b) reforçado ajuste linear (c) reforçado ajuste curvo

As Figuras 5.43 (a) e (b) mostram as linhas de transformação de fase para o rejeito de minério de ouro não reforçado e reforçado, sendo os ângulos de atrito na transformação de fase ( $\left.\phi^{\prime}{ }_{\text {LTF }}\right)$ de $25,9^{\circ}$ e $26,8^{\circ}$, respectivamente. 
Observa-se que a linha de transformação de fase no caso reforçado é melhor representada por um ajuste curvo como mostra a Figura 5.43 (c). Nota-se que para ambos os rejeitos de minério não existe muita diferença entre o ângulo mobilizado de transformação de fase reforçado ou não reforçado, sendo o reforçado levemente maior.

\subsubsection{2.}

\section{Ângulo de atrito Mobilizado}

No item anterior calculou-se o ângulo de atrito mobilizado na transformação de fase, as Figuras 5.44 e 5.45 apresentam a mobilização do ângulo de atrito durante todo o ensaio com respeito à taxa de variação da poropressão normalizada pela tensão efetiva de confinamento, com a finalidade de visualizar a influência na mudança da poropressão na tendência volumétrica dos rejeitos de minério de ferro e ouro, não reforçados e reforçados. As Figuras 5.45 (a) e (b), apresentam as curvas de ângulo de atrito mobilizado do rejeito de minério de ferro não reforçado e reforçado, respectivamente, mostrando a linha de transformação de fase, e ao mesmo tempo, a posição do ângulo de atrito crítico calculado no item 5.2.3.

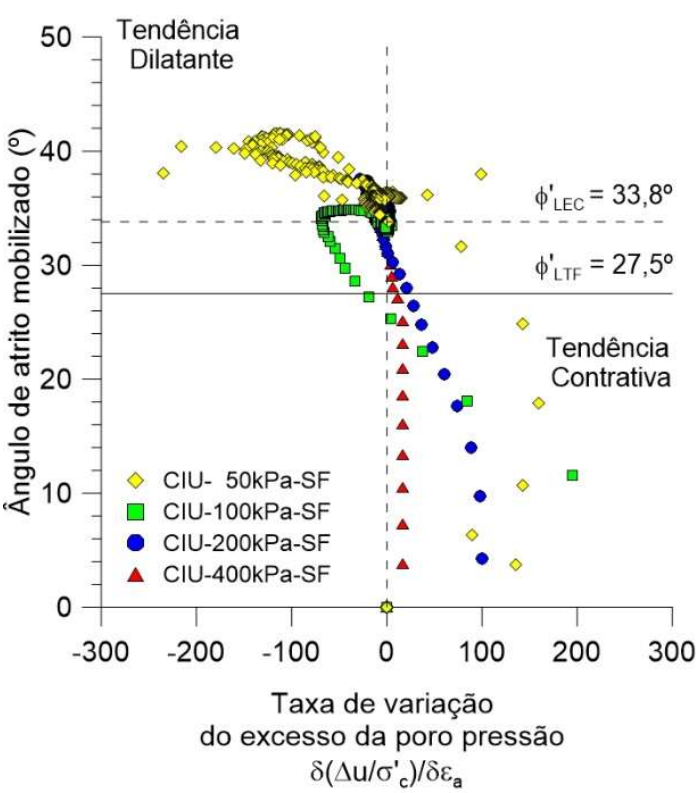

(a)

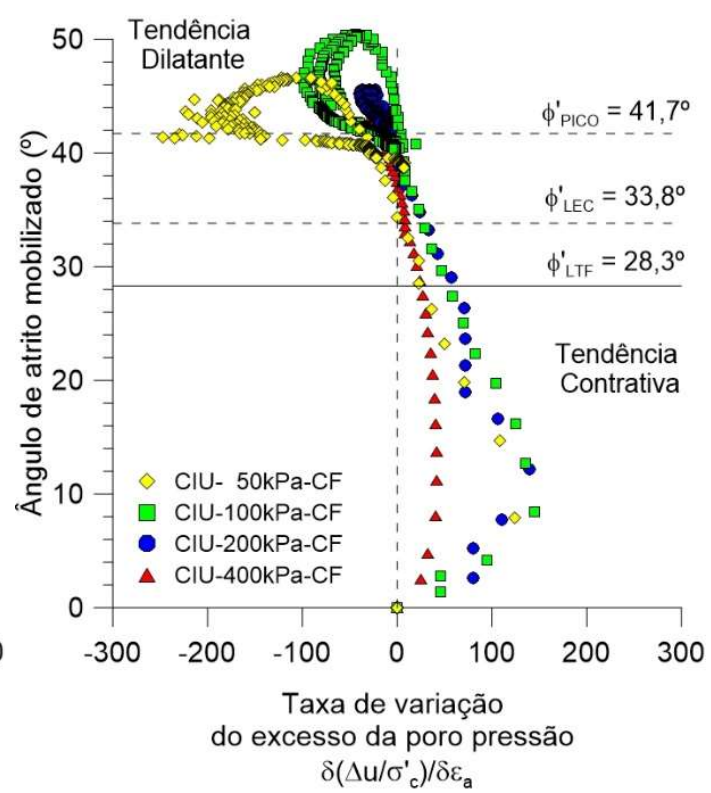

(b)

Figura 5.44. Ângulo de atrito mobilizado (RMFe)

Rejeito de minério de ferro

(a) não reforçado (b) reforçado

No rejeito de minério de ferro não reforçado, após atingir a linha de transformação de fase, os ângulos de atrito mobilizados de cada tensão efetiva de 
confinamento aumentam até um máximo e diminuem até chegar ao ângulo de atrito crítico próximo ao ângulo de atrito de pico da envoltória, todos dentro da parte da tendência à mudança de volume dilatante do material. No caso reforçado, os ângulos mobilizados aumentam até um valor máximo e diminuem até ficar estáveis no valor do ângulo de atrito de pico da envoltória reforçada, todo dentro da parte dilatante.

Observa-se que a adição de fibra aumenta a tendência dilatante do rejeito de minério de ferro na condição não drenada.

As Figuras 5.45 (a) e (b) apresentam as curvas de ângulo de atrito mobilizado vs. taxa de variação de poropressão normalizada, do rejeito de minério de ouro não reforçado e reforçado, respectivamente, mostrando a linha de transformação de fase, e ao mesmo tempo, a posição do ângulo de atrito crítico calculado no item 5.1.3.

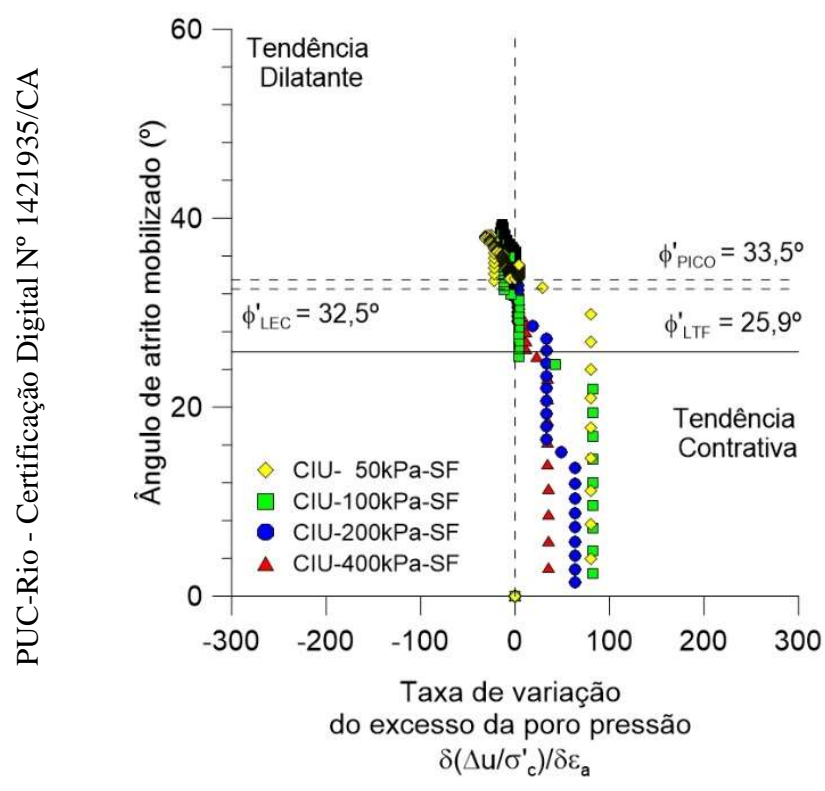

(a)

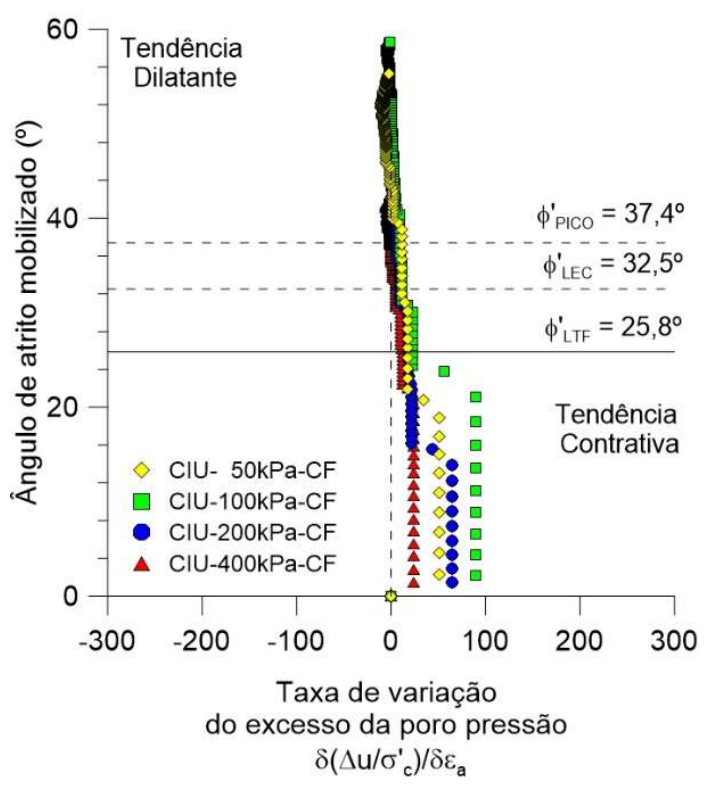

(b)

Figura 5.45. Ângulo de atrito mobilizado (RMAu) Rejeito de minério de ouro

(a) não reforçado (b) reforçado

Observa-se que, no rejeito de minério de ouro, as fibras suprimem a tendência contrativa do rejeito, mas não produzem um aumento dilatante, passando o rejeito a um estado de estabilidade. No caso reforçado, o ângulo de atrito mobilizado continua aumentando e não diminui para o valor do ângulo de atrito de pico da envoltória, diferente do caso não reforçado. 


\section{2. \\ Ensaios de cisalhamento direto}

Os ensaios de plano cisalhado com superfície polida, foram realizados para descrever o comportamento residual dos rejeitos de mineração reforçados. Tais ensaios se realizaram após o ensaio convencional. Para separar as caixas superior e inferior, um fio fino de aço é passado ao longo da superfície de ruptura obtida pelo ensaio convencional, localizada na interfase das caixas. Uma vez se faz o polimento das respectivas superfícies que depois se colocam novamente em contato, gerando a superfície de ruptura residual. Finalmente a caixa é colocada no equipamento e realiza-se o ensaio na mesma velocidade de cisalhamento do ensaio convencional.

\subsection{1.}

\section{Rejeito de Minério de Ferro}

A Tabela 5.19 mostra os índices físicos das amostras do rejeito de minério de ferro não reforçado e reforçado depois da moldagem, após o adensamento e no final do ensaio de cisalhamento direto convencional (CDc) não reforçado e reforçado.

Tabela 5.19. Variação dos índices físicos - cisalhamento direto (RMFe) Ensaios de cisalhamento direto - Rejeito de Minério de Ferro

\begin{tabular}{|c|c|c|c|c|c|c|c|c|c|c|}
\hline \multirow{2}{*}{ Ensaio } & \multirow{2}{*}{$\begin{array}{c}\sigma_{\mathrm{n}}^{\prime} \\
(\mathrm{kPa})\end{array}$} & \multicolumn{6}{|c|}{$\begin{array}{l}\text { Índices físicos } \\
\text { Iniciais }\end{array}$} & $\begin{array}{c}\text { Após o } \\
\text { adensamento }\end{array}$ & \multicolumn{2}{|c|}{ Final } \\
\hline & & $\begin{array}{l}\mathrm{W}_{\mathrm{o}} \\
\%\end{array}$ & $\begin{array}{c}\gamma_{\mathrm{n}} \\
\mathrm{kN} / \mathrm{m}^{3}\end{array}$ & $\begin{array}{c}\gamma_{\mathrm{d}} \\
\mathrm{kN} / \mathrm{m}^{3}\end{array}$ & $\mathrm{e}_{\mathrm{o}}$ & $\begin{array}{l}\mathrm{n} \\
\%\end{array}$ & $\begin{array}{l}\mathrm{S} \\
\%\end{array}$ & $\mathrm{e}_{\text {adens. }}$ & $e_{f}$ & $\begin{array}{l}\mathrm{W}_{\mathrm{f}} \\
\%\end{array}$ \\
\hline Fe- CDc- 25-sf & 25 & 12,28 & 19,76 & 17,60 & 0,643 & 39,15 & 55,23 & 0,565 & 0,564 & 22,18 \\
\hline Fe- CDc- 50-sf & 50 & 12,25 & 19,75 & 17,60 & 0,644 & 39,16 & 55,06 & 0,554 & 0,553 & 22,29 \\
\hline Fe- CDc-100-sf & 100 & 12,23 & 19,75 & 17,60 & 0,644 & 39,16 & 54,98 & 0,517 & 0,513 & 22,64 \\
\hline Fe- CDc-200-sf & 200 & 12,23 & 19,75 & 17,60 & 0,644 & 39,15 & 54,98 & 0,478 & 0,474 & 22,45 \\
\hline Fe- CDc-400-sf & 400 & 12,27 & 19,75 & 17,59 & 0,644 & 39,18 & 55,11 & 0,424 & 0,421 & 22,91 \\
\hline Fe- CDc- 25-cf & 25 & 12,39 & 19,81 & 17,62 & 0,641 & 39,06 & 55,92 & 0,616 & 0,619 & 23,11 \\
\hline Fe- CDc- 50-cf & 50 & 12,28 & 19,81 & 17,65 & 0,639 & 0,586 & 55,60 & 0,586 & 0,589 & 22,86 \\
\hline Fe- CDc-100-cf & 100 & 12,48 & 19,82 & 17,62 & 0,642 & 39,08 & 56,24 & 0,642 & 0,583 & 22,70 \\
\hline Fe- CDc-200-cf & 200 & 12,53 & 19,82 & 17,62 & 0,642 & 39,09 & 56,44 & 0,541 & 0,542 & 22,59 \\
\hline Fe- CDc-400-cf & 400 & 12,49 & 19,81 & 17,61 & 0,642 & 39,10 & 56,27 & 0,477 & 0,475 & 22,78 \\
\hline
\end{tabular}

As Figuras 5.46 e 5.47, apresentam os resultados correspondentes ao rejeito de minério de ferro não reforçado e reforçado respectivamente, sob os ensaios de cisalhamento direto convencional e plano cisalhado com superfície polida. Os gráficos mostrados são: $\tau$ vs. $d_{h}, d_{v}$ vs. $d_{h}$ e $\tau / \sigma_{n}$ vs. $d_{h}$, onde: $\tau=$ tensão cisalhante, $\sigma_{\mathrm{n}}=$ tensão normal vertical, $\mathrm{d}_{\mathrm{h}}=$ deslocamento horizontal, $\mathrm{d}_{\mathrm{v}}=$ deslocamento vertical e, $\tau / \sigma_{\mathrm{n}}=$ tensão cisalhante normalizada pela tensão normal vertical. 
As Tabelas 5.20 e 5.21 mostram os resultados obtidos a partir dos ensaios de cisalhamento direto convencional e de plano cisalhado com superfície polida para o rejeito de minério de ferro não reforçado e reforçado, respectivamente.

Tabela 5.20. Resultados Rejeito de Minério de Ferro não reforçado

\begin{tabular}{cccccccc}
\hline & & \multicolumn{3}{c}{ Dados na Ruptura } & \multicolumn{3}{c}{$\begin{array}{c}\text { Dados na Ruptura } \\
\text { residual }\end{array}$} \\
\cline { 3 - 9 } Ensaio & $\begin{array}{c}\sigma ’ n \\
\mathrm{kPa}\end{array}$ & $\delta \mathrm{h}$ & $\begin{array}{c}\tau \\
\mathrm{kPa}\end{array}$ & $\begin{array}{c}\sigma ' n \\
\mathrm{kPa}\end{array}$ & $\begin{array}{c}\delta \mathrm{h} \\
\mathrm{mm}\end{array}$ & $\begin{array}{c}\tau \\
\mathrm{kPa}\end{array}$ & $\begin{array}{c}\sigma^{\prime} \mathrm{n} \\
\mathrm{kPa}\end{array}$ \\
\hline Fe- CD- 25-sf & 25 & 7,85 & 16,54 & 26,68 & 0,95 & 3,89 & 24,85 \\
Fe- CD- 50-sf & 50 & 6,80 & 25,25 & 51,64 & 3,60 & 25,49 & 49,95 \\
Fe- CD-100-sf & 100 & 7,20 & 72,00 & 105,65 & 4,40 & 53,77 & 102,60 \\
Fe- CD-200-sf & 200 & 4,50 & 127,46 & 207,28 & 4,50 & 116,18 & 207,28 \\
Fe- CD-400-sf & 400 & 4,10 & 266,34 & 408,09 & 4,80 & 208,17 & 411,25 \\
\hline
\end{tabular}

Tabela 5.21. Resultados Rejeito de Minério de Ferro reforçado

\begin{tabular}{|c|c|c|c|c|c|c|c|}
\hline \multirow{2}{*}{ Ensaio } & \multirow{2}{*}{$\begin{array}{l}\sigma^{\prime} n \\
\mathrm{kPa}\end{array}$} & \multicolumn{3}{|c|}{$\begin{array}{c}\text { Dados na Ruptura } \\
\text { de pico }\end{array}$} & \multicolumn{3}{|c|}{$\begin{array}{l}\text { Dados na Ruptura } \\
\text { residual }\end{array}$} \\
\hline & & $\begin{array}{c}\delta \mathrm{h} \\
\mathrm{mm}\end{array}$ & $\begin{array}{c}\tau \\
\mathrm{kPa}\end{array}$ & $\begin{array}{l}\sigma ’ n \\
\mathrm{kPa}\end{array}$ & $\begin{array}{c}\delta \mathrm{h} \\
\mathrm{mm}\end{array}$ & $\begin{array}{c}\tau \\
\mathrm{kPa}\end{array}$ & $\begin{array}{l}\sigma ’ n \\
\mathrm{kPa}\end{array}$ \\
\hline Fe- CD- 25-cf & 25 & 7,05 & 23,82 & 26,97 & 2,95 & 17,12 & 25,85 \\
\hline Fe- CD- 50-cf & 50 & 7,70 & 44,38 & 54,19 & 5,00 & 31,79 & 52,68 \\
\hline Fe- CD-100-cf & 100 & 10,95 & 94,02 & 110,02 & 6,05 & 69,20 & 104,38 \\
\hline Fe- CD-200-cf & 200 & 13,95 & 183,50 & 232,43 & 5,90 & 133,94 & 212,86 \\
\hline Fe- CD-400-cf & 400 & 15,00 & 358,90 & 459,52 & 5,00 & 279,15 & 412,12 \\
\hline
\end{tabular}

$\mathrm{Na}$ Figura 5.46(a) de tensão cisalhante vs. deslocamento horizontal, os rejeitos de minério de ferro não reforçados, sob tensões normais verticais de 25 e $50 \mathrm{kPa}$ mostraram presença de picos de tensão pouco pronunciados, enquanto nas tensões de 100, 200 e $400 \mathrm{kPa}$ foram bem definidas.

As curvas de deslocamento horizontal vs. deslocamento vertical na Figura 5.46(a) mostram que o comportamento predominante do rejeito de minério de ferro é de compressão para todas as tensões normais verticais utilizadas, enquanto a estabilização das curvas da Figura 5.46(b), mostra que a fase residual foi alcançada.

As curvas de tensão cisalhante normalizada $\left(\tau / \sigma_{n}\right)$ na Figura 5.46(a) apresentam uma tendência similar para todas as tensões normais verticais mostrando certa homogeneidade no comportamento cisalhante do rejeito, no caso residual, da Figura 5.46(b), a homogeneidade é maior para todas as tensões com exceção da tensão de $25 \mathrm{kPa}$.

No caso reforçado, no gráfico de tensão cisalhante vs. deslocamento horizontal da Figura 5.47(a), as tensões de 25, 50, 100 e 200 kPa, apresentaram uma tensão de pico levemente percebível, enquanto a tensão de $400 \mathrm{kPa}$ apresentou um comportamento de strain hardening até o fim do ensaio. 

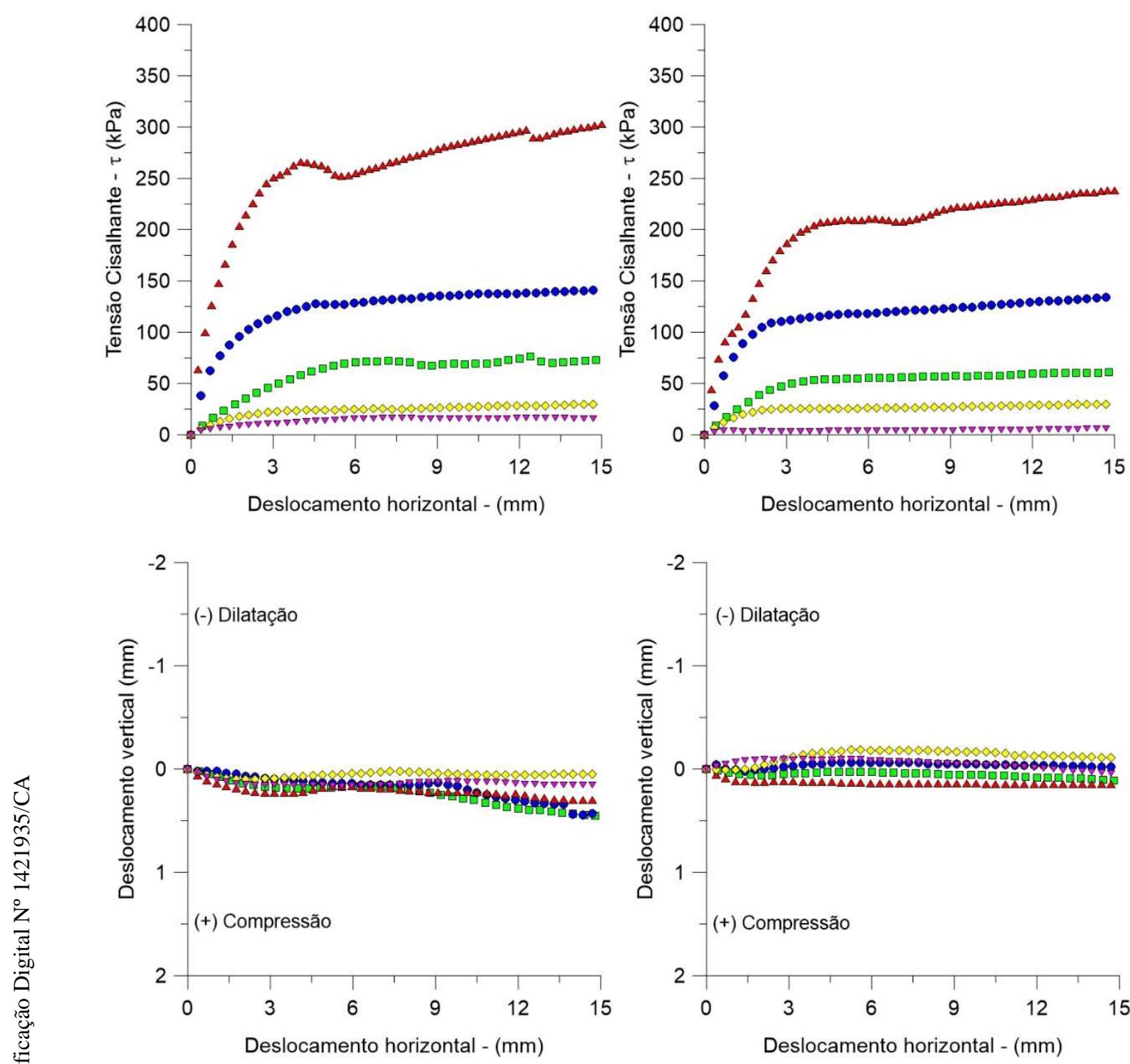

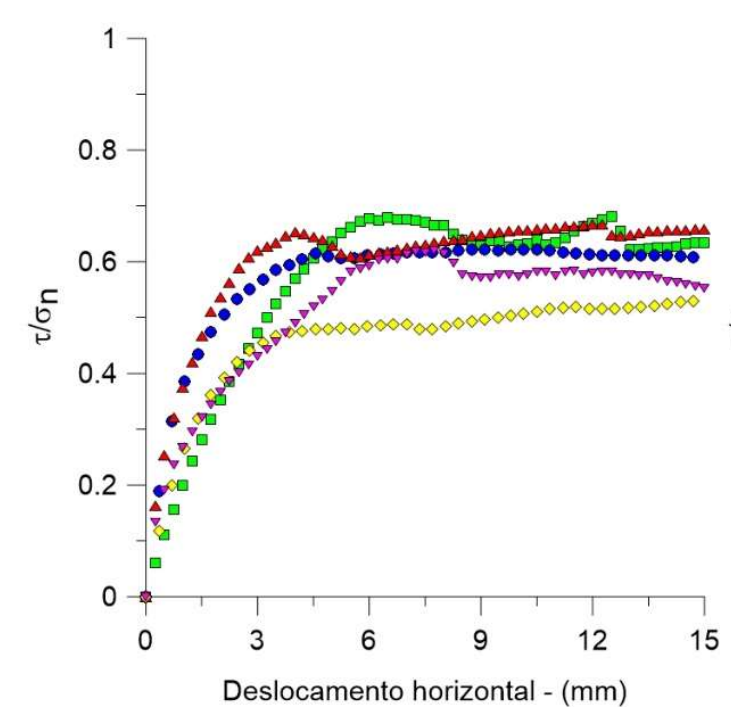

(a)

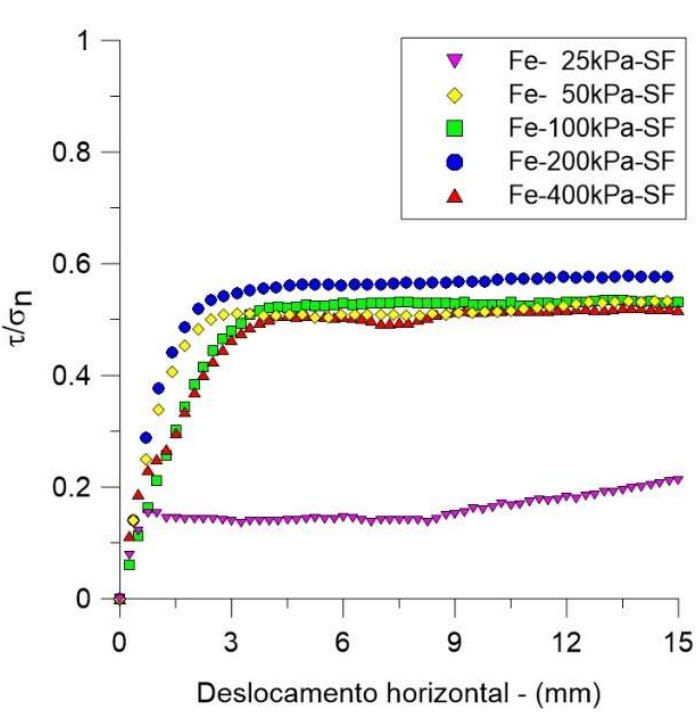

(b)

Figura 5.46. Cisalhamento direto não reforçado (RMFe) Rejeito de Minério de Ferro

(a) convencional e de (b) plano cisalhado com superfície polida 

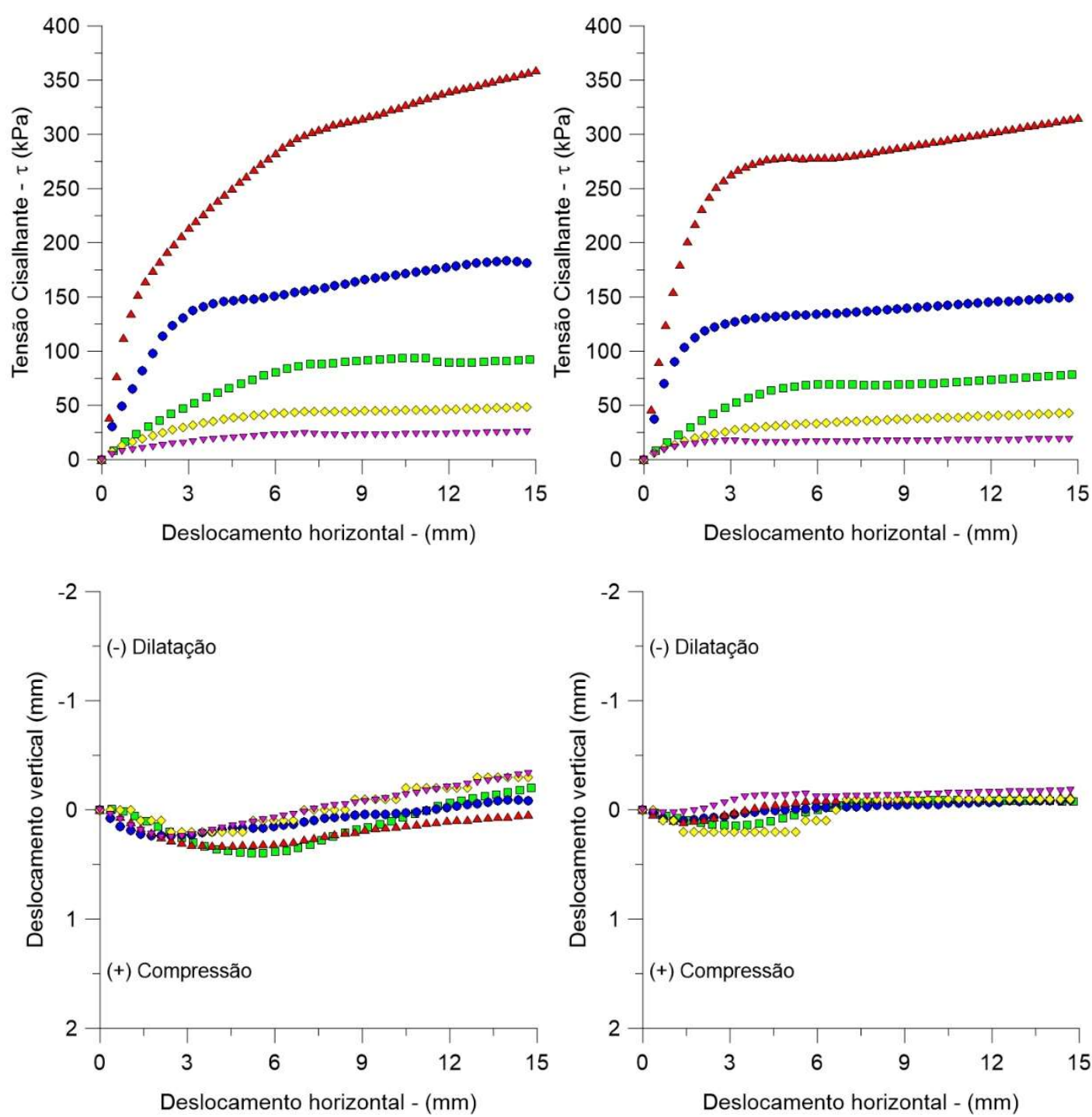

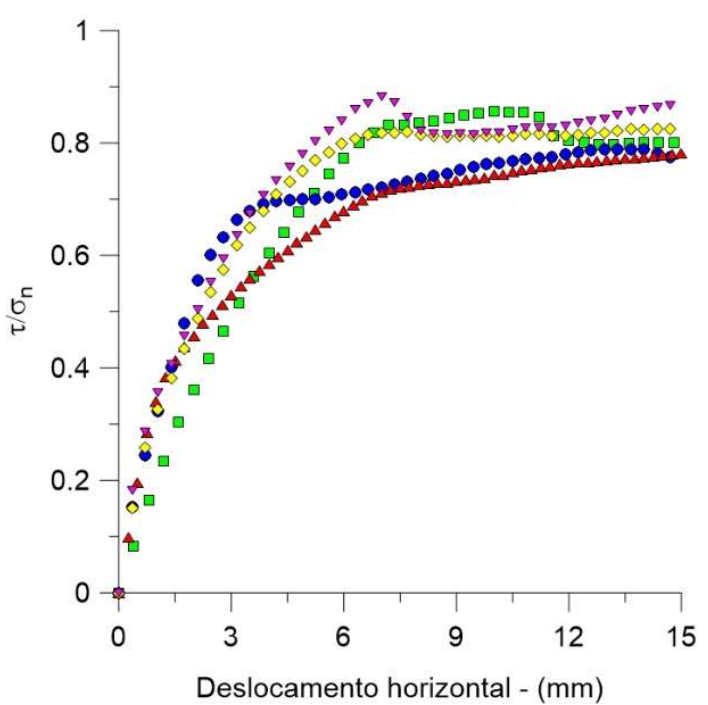

(a)

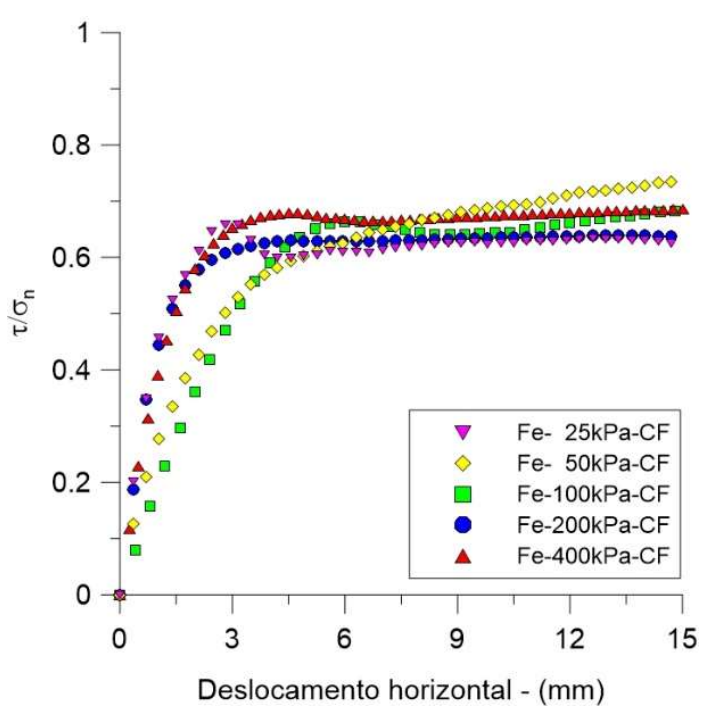

(b)

Figura 5.47. Cisalhamento direto reforçado (RMFe)

Rejeito de Minério de Ferro

(a) convencional e de (b) plano cisalhado com superfície polida 
As curvas de deslocamento horizontal vs. deslocamento vertical, na Figura 5.47(a), mostram que o comportamento do rejeito de minério de ferro reforçado é inicialmente de compressão, mas a tendência é suprimida entre 3 e $6 \mathrm{~mm}$, posteriormente, o comportamento é dilatante até o final do ensaio para todas as tensões normais verticais utilizadas, enquanto a estabilização das curvas da Figura 5.47(b) mostra o estado residual do rejeito reforçado.

As curvas de tensão cisalhante normalizada na Figura 5.47(a) apresentam uma tendência similar para todas as tensões normais verticais mostrando certa homogeneidade no comportamento cisalhante do rejeito reforçado. No caso da Figura 5.47(b) a homogeneidade é ainda maior para todas as tensões.

As envoltórias, não reforçada e reforçada, de tensão cisalhante vs. tensão normal utilizadas para calcular os parâmetros de resistência dos ensaios de cisalhamento direto convencional e de plano cisalhado com superfície polida são mostradas nas Figuras 5.48(a) e (b), respectivamente.

As correlações lineares foram superiores a 0,99 , isto mostra que não existe uma significativa distinção entre o comportamento de baixas (até $100 \mathrm{kPa}$ ) e altas $(>100 \mathrm{kPa})$ tensões.

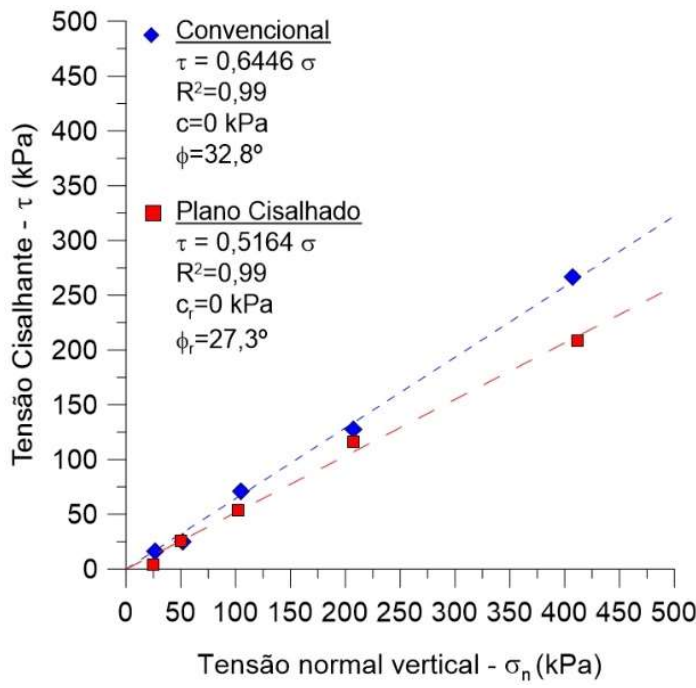

(a)

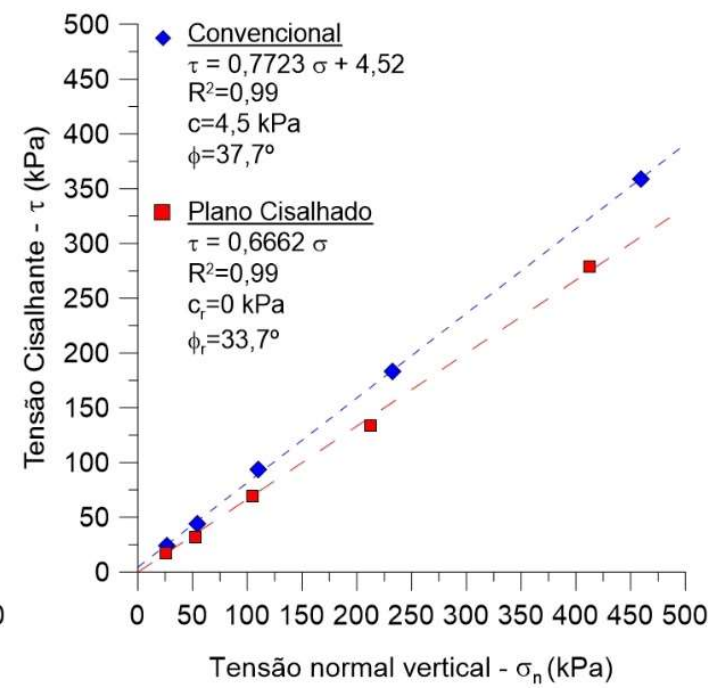

(b)

Figura 5.48. Resultados do cisalhamento direto (RMFe)

Rejeito de Minério de Ferro

(a) não reforçado (b) reforçado

Observa-se na Figura 5.48(b) que, com uma adição de 0,5\% de fibras de polipropileno, os parâmetros de resistência do rejeito de minério de ferro incrementam de $32,8^{\circ}$ a $37,7^{\circ}$ enquanto no estado residual de $27,3^{\circ}$ a $33,7^{\circ}$. 
O rejeito reforçado no ensaio de plano cisalhado, apresenta um valor de ângulo de atrito maior do que no caso não reforçado convencional, isto pode ser porque as fibras, localizadas na interface das caixas superior e inferior, que resistem à força de arrancamento exercida sobre elas pelo deslocamento durante o ensaio, trabalhando até como micro ancoragens, que ficam aderidos em ambas as superfícies porque no adensamento prévio ao reinicio do ensaio existe um efeito de "cicatrização" do plano de cisalhamento sobretudo em altas tensões.

O rejeito não reforçado não apresenta intercepto coesivo, mas com a adição do reforço nota-se um valor de $4,5 \mathrm{kPa}$, isto se deve a dois fatos, a resistência à tração das fibras que interceptam a superfície de cisalhamento e a um pequeno acréscimo de confinamento dado pelas fibras que ficam ao redor dos grãos formando pequenos pacotes de rejeito.

\subsection{2.}

\section{Rejeito de Minério de Ouro}

\begin{tabular}{|c|c|c|c|c|c|c|c|c|c|c|}
\hline \multicolumn{11}{|c|}{$\begin{array}{l}\text { A Tabela } 5.22 \text { mostra os índices físicos das amostras do rejeito de minério } \\
\text { ouro não reforçado e reforçado depois da moldagem, após o adensamento e no fir } \\
\text { do ensaio. } \\
\text { Tabela 5.22. Variação dos índices físicos - cisalhamento direto (RMAu) } \\
\text { Ensaios de cisalhamento direto - Rejeito de Minério de Ouro }\end{array}$} \\
\hline \multirow{2}{*}{ Ensaio } & \multirow{2}{*}{$\begin{array}{l}\sigma_{\mathrm{v}}^{\prime} \\
\mathrm{kPa}\end{array}$} & \multicolumn{6}{|c|}{$\begin{array}{c}\text { Índices físicos } \\
\text { Iniciais }\end{array}$} & \multirow{2}{*}{$\begin{array}{c}\begin{array}{c}\text { Após o } \\
\text { adensamento }\end{array} \\
\text { eadens. }\end{array}$} & \multicolumn{2}{|c|}{ Final } \\
\hline & & $\begin{array}{l}\mathrm{W}_{\mathrm{o}} \\
\%\end{array}$ & $\begin{array}{c}\gamma_{\mathrm{n}} \\
\mathrm{kN} / \mathrm{m}^{3}\end{array}$ & $\begin{array}{c}\gamma_{\mathrm{d}} \\
\mathrm{kN} / \mathrm{m}^{3}\end{array}$ & $\mathrm{e}_{\mathrm{o}}$ & $\begin{array}{l}\mathrm{n} \\
\%\end{array}$ & $\begin{array}{c}\mathrm{S} \\
\%\end{array}$ & & $e_{f}$ & $\begin{array}{l}\mathrm{W}_{\mathrm{f}} \\
\%\end{array}$ \\
\hline Au-CDc-25-sf & 25 & 16,17 & 21,62 & 18,61 & 1,030 & 50,74 & 59,30 & 0,968 & 0,965 & 22,34 \\
\hline 4u-CDc-50-sf & 50 & 16,59 & 21,45 & 18,40 & 1,053 & 51,28 & 59,51 & 0,953 & 0,951 & 22,81 \\
\hline Au-CDc-100-sf & 100 & 16,51 & 20,92 & 17,95 & 0,897 & 52,47 & 56,51 & 0,897 & 0,896 & 21,27 \\
\hline Au-CDc-200-sf & 200 & 16,52 & 22,31 & 19,15 & 0,973 & 49,30 & 64,16 & 0,764 & 0,759 & 22,57 \\
\hline Au-CDc-400-sf & 400 & 16,07 & 22,29 & 19,21 & 0,967 & 49,15 & 62,78 & 0,475 & 0,464 & 22,82 \\
\hline $\mathrm{Au}-\mathrm{CDc}-25-\mathrm{cf}$ & 25 & 16,14 & & 20,19 & 0,870 & 46,54 & 70,04 & 0,710 & 0,710 & 21,20 \\
\hline Au-CDc-50-cf & 50 & 16,55 & 24,35 & 20,89 & 0,808 & 44,69 & 77,36 & 0,673 & 0,676 & 22,76 \\
\hline Au-CDc-100-cf & 100 & 16,12 & 24,57 & 21,16 & 0,785 & 43,98 & 77,56 & 0,606 & 0,608 & 22,09 \\
\hline Au-CDc-200-cf & 200 & 16,18 & 24,66 & 21,23 & 0,779 & 43,79 & 78,44 & 0,546 & 0,546 & 22,79 \\
\hline Au-CDc-400-cf & 400 & 16,25 & 25,51 & 21,95 & 0,721 & 41,89 & 85,13 & 0,379 & 0,381 & 22,81 \\
\hline
\end{tabular}

Nas Figuras 5.49 e 5.50 apresentam-se os resultados correspondentes ao rejeito de minério de ouro não reforçado e reforçado respectivamente, sob os ensaios de cisalhamento direto convencional e plano cisalhado com superfície polida.

Os gráficos mostrados são: $\tau$ vs. $d_{h}, d_{v}$ vs. $d_{h}$ e $\tau / \sigma_{n}$ vs. $d_{h}$, onde: $\tau=$ tensão cisalhante, $\sigma_{\mathrm{n}}=$ tensão normal vertical, $\mathrm{d}_{\mathrm{h}}=$ deslocamento horizontal, 
$\mathrm{d}_{\mathrm{v}}=$ deslocamento vertical e, $\tau / \sigma_{\mathrm{n}}=$ tensão cisalhante normalizada pela tensão normal vertical.

As Tabelas 5.23 e 5.24 mostram os resultados obtidos a partir dos ensaios de cisalhamento direto convencional e de plano cisalhado com superfície polida para o rejeito de minério de ouro não reforçado e reforçado, respectivamente.

Tabela 5.23. Resultados Rejeito de Minério de Ouro não reforçado

\begin{tabular}{|c|c|c|c|c|c|c|c|}
\hline \multirow{2}{*}{ Ensaio } & \multirow{2}{*}{$\begin{array}{c}\sigma^{\prime} \mathrm{n} \\
(\mathrm{kPa})\end{array}$} & \multicolumn{3}{|c|}{$\begin{array}{c}\text { Dados na Ruptura } \\
\text { de pico } \\
\end{array}$} & \multicolumn{3}{|c|}{$\begin{array}{c}\text { Dados na Ruptura } \\
\text { residual }\end{array}$} \\
\hline & & $\begin{array}{c}\delta \mathrm{h} \\
\mathrm{mm}\end{array}$ & $\begin{array}{c}\tau \\
\mathrm{kPa} \\
\end{array}$ & $\begin{array}{l}\sigma^{\prime} \mathrm{n} \\
\mathrm{kPa}\end{array}$ & $\begin{array}{c}\delta \mathrm{h} \\
\mathrm{mm}\end{array}$ & $\begin{array}{c}\tau \\
\mathrm{kPa} \\
\end{array}$ & $\begin{array}{l}\sigma ’ n \\
\mathrm{kPa} \\
\end{array}$ \\
\hline Fe-CD- 25-sf & 25 & 5,25 & 22,16 & 26,47 & 3,00 & 12,04 & 25,86 \\
\hline Fe-CD- 50-sf & 50 & 6,70 & 47,35 & 53,62 & 3,75 & 30,65 & 52,00 \\
\hline Fe- CD-100-sf & 100 & 12,55 & 98,58 & 117,43 & 4,35 & 58,48 & 107,52 \\
\hline Fe- CD-200-sf & 200 & 7,45 & 163,18 & 216,35 & 4,60 & 113,84 & 210,00 \\
\hline Fe- CD-400-sf & 400 & 13,05 & 263,81 & 459,44 & 5,00 & 247,80 & 421,10 \\
\hline
\end{tabular}

Tabela 5.24. Resultados Rejeito de Minério de Ouro reforçado

\begin{tabular}{|c|c|c|c|c|c|c|c|}
\hline \multirow{2}{*}{ Ensaio } & \multirow{2}{*}{$\begin{array}{c}\sigma^{\prime} \mathrm{n} \\
(\mathrm{kPa})\end{array}$} & \multicolumn{3}{|c|}{$\begin{array}{c}\text { Dados na Ruptura } \\
\text { de pico }\end{array}$} & \multicolumn{3}{|c|}{$\begin{array}{c}\text { Dados na Ruptura } \\
\text { residual }\end{array}$} \\
\hline & & $\begin{array}{c}\delta \mathrm{h} \\
\mathrm{mm}\end{array}$ & $\begin{array}{c}\tau \\
\mathrm{kPa}\end{array}$ & $\begin{array}{l}\sigma ’ \mathrm{n} \\
\mathrm{kPa}\end{array}$ & $\begin{array}{c}\delta \mathrm{h} \\
\mathrm{mm}\end{array}$ & $\begin{array}{c}\tau \\
\mathrm{kPa}\end{array}$ & $\begin{array}{l}\sigma ’ \mathrm{n} \\
\mathrm{kPa}\end{array}$ \\
\hline Fe- CD- 25-cf & 25 & 15,00 & 25,44 & 29,45 & 2,75 & 10,86 & 27,80 \\
\hline Fe- CD- 50-cf & 50 & 9,70 & 61,82 & 55,38 & 4,00 & 36,38 & 52,14 \\
\hline Fe- CD-100-cf & 100 & 11,10 & 110,61 & 115,55 & 5,60 & 75,15 & 108,93 \\
\hline Fe- CD-200-cf & 200 & 9,00 & 198,68 & 220,00 & 2,55 & 135,15 & 205,65 \\
\hline Fe- CD-400-cf & 400 & 7,00 & 400,84 & 430,04 & 5,65 & 287,80 & 424,01 \\
\hline
\end{tabular}

Na Figura 5.49(a) de tensão cisalhante vs. deslocamento horizontal, todas as amostras apresentaram tensão de pico com exceção amostra de $400 \mathrm{kPa}$ que apresentou um acréscimo continuo da tensão cisalhante.

No caso da Figura 5.49(b) todas as amostras estabilizaram mostrando que se atingiu a resistência residual.

As curvas de deslocamento horizontal vs. deslocamento vertical na Figura 5.49(a) mostram que o comportamento predominante do rejeito de minério de ouro é de compressão, mas que aproximadamente em um deslocamento horizontal de $3 \mathrm{~mm}$ começa uma inibição da compressão se estabilizando os deslocamentos verticais o que não acontece com a tensão de $400 \mathrm{kPa}$ que continua com a tendência de compressão.

Na Figura 5.49(b), a estabilização do deslocamento vertical das amostras mostra que a fase residual foi alcançada. 


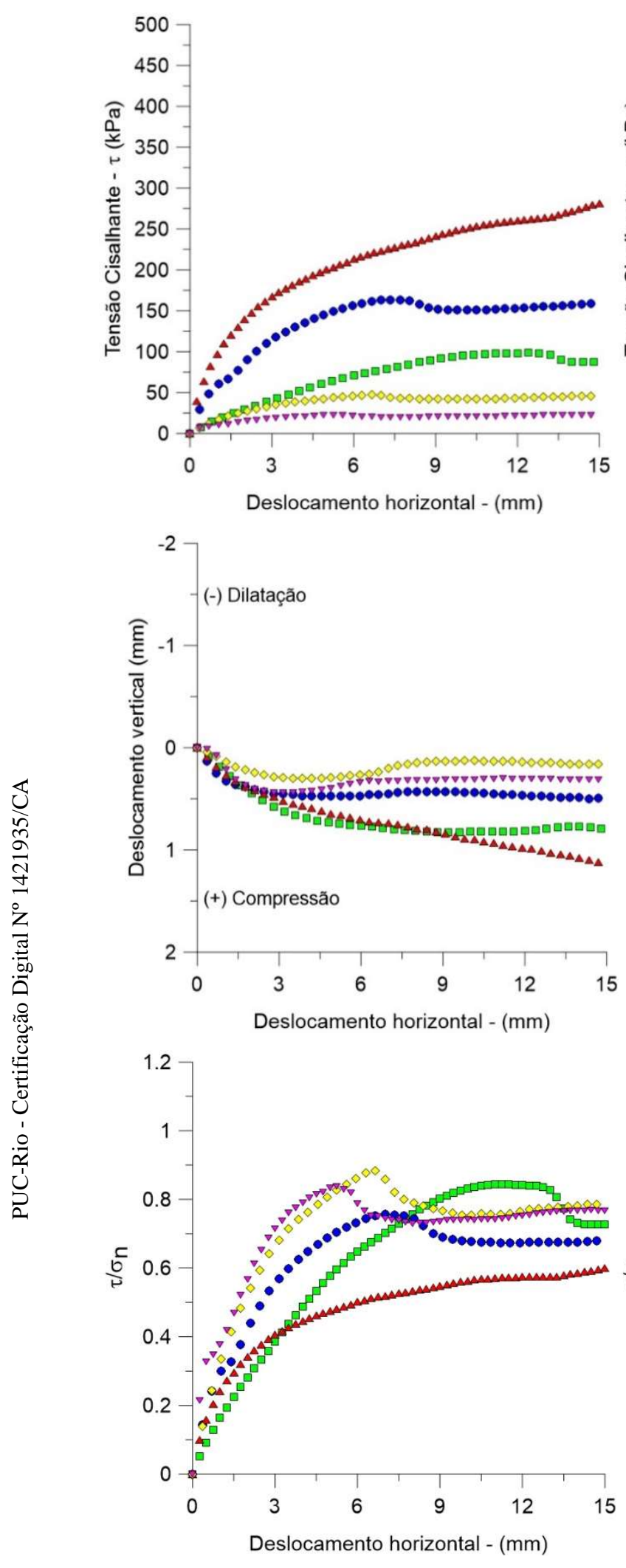

(a)
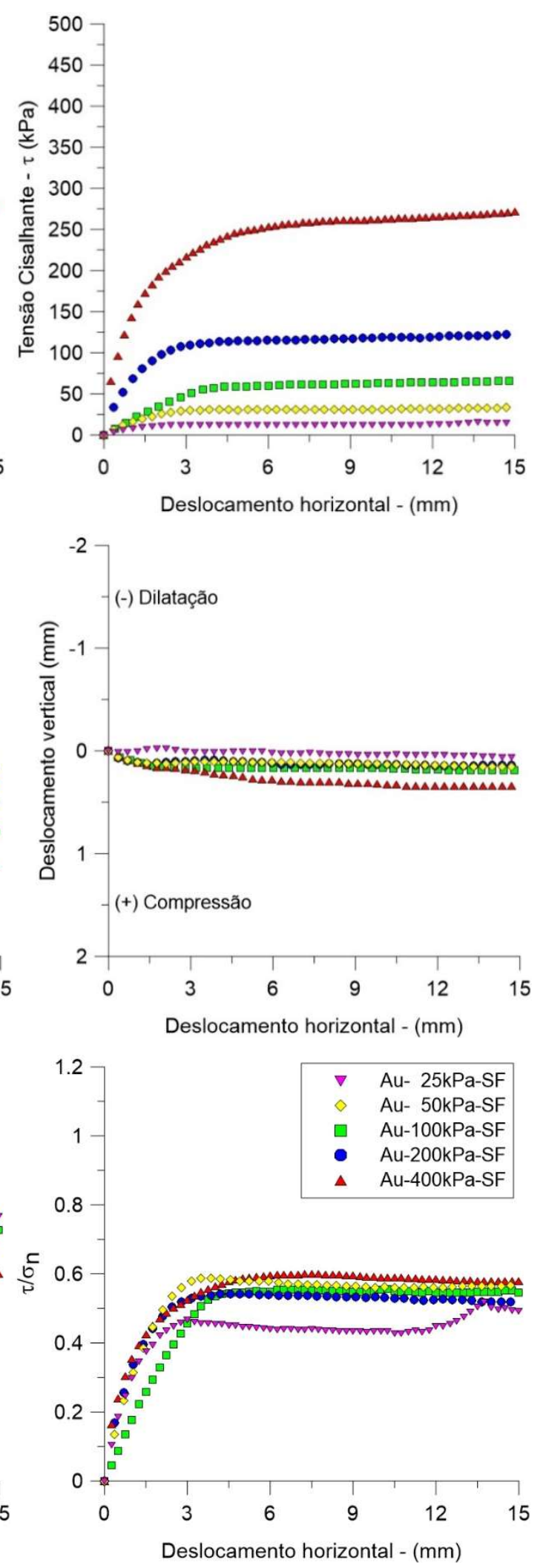

(b)

Figura 5.49. Cisalhamento direto não reforçado (RMAu) Rejeito de Minério de Ouro

(a) convencional e de (b) plano cisalhado com superfície polida 

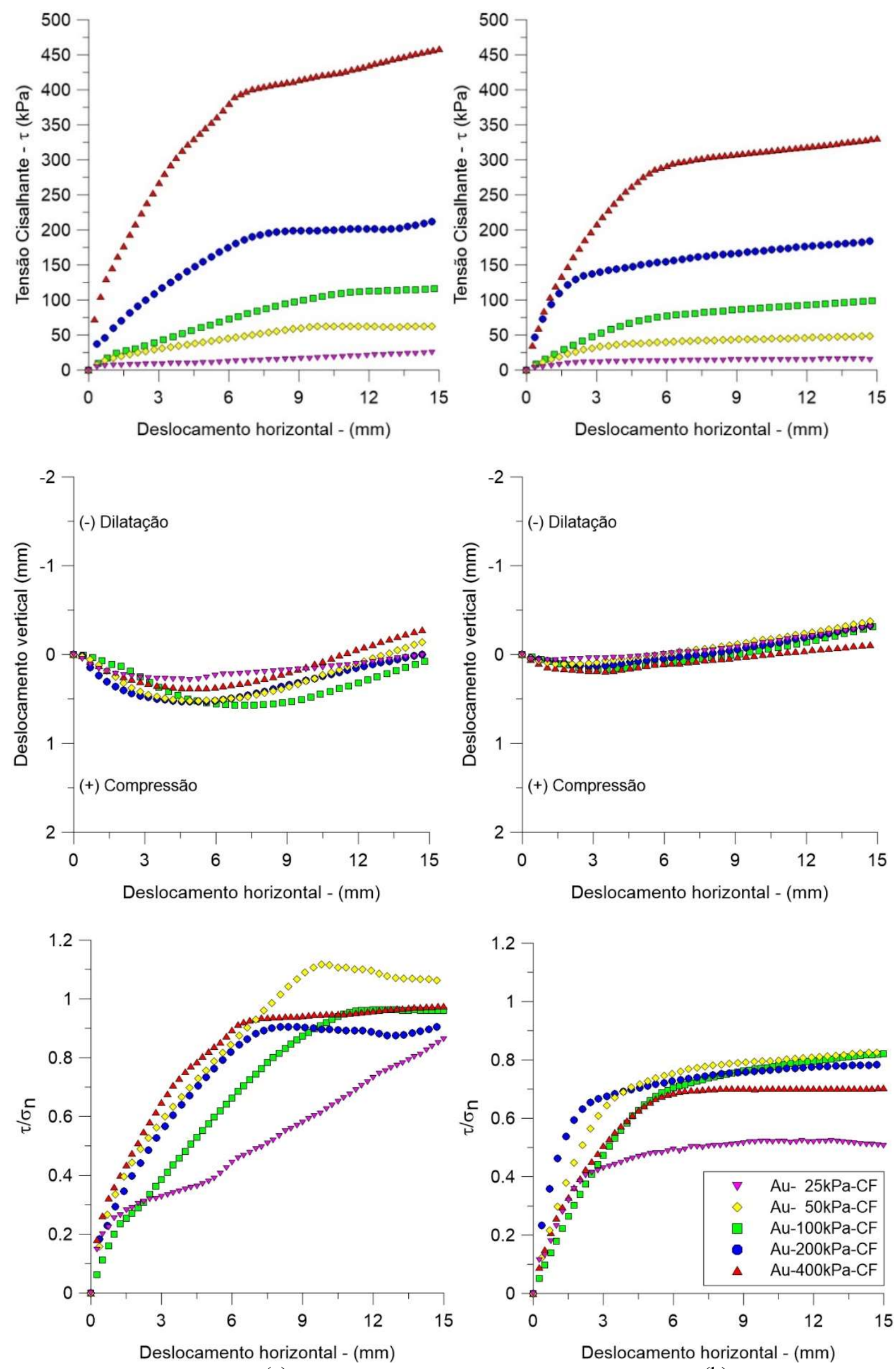

(a)

(b)

Figura 5.50. Cisalhamento direto reforçado (RMAu) Rejeito de Minério de Ouro

(a) convencional e de (b) plano cisalhado com superfície polida 
As curvas de tensão cisalhante normalizada na Figura 5.49(a) apresentam uma tendência similar para todas as tensões normais verticais mostrando os picos mencionados anteriormente com exceção da tensão de $400 \mathrm{kPa}$, no caso da Figura 5.49(b) a homogeneidade é mais estreita para todas as tensões com exceção da tensão de $25 \mathrm{kPa}$.

No caso reforçado, nos gráficos de tensão cisalhante vs. deslocamento horizontal das Figuras 5.50(a) e (b), não se apresentaram tensões de pico, observase um constante incremento das tensões com o deslocamento. Nesse caso, para desenhar a envoltória foram usados os pontos onde muda a inclinação da curva, tensão cisalhante vs. deslocamento, considerando que a matriz começou a fissurar.

As curvas de deslocamento horizontal vs. deslocamento vertical na Figura 5.50(a) mostram que o comportamento do rejeito de minério de ouro reforçado é inicialmente de compressão até $6 \mathrm{~mm}$ de deslocamento horizontal onde a resposta volumétrica do rejeito muda para dilatante em todas as tensões verticais até o final do ensaio, enquanto todas as curvas da Figura 5.50(b) inicialmente tem um comportamento residual estável, mas a partir de $3 \mathrm{~mm}$ de deslocamento horizontal, mostram um comportamento totalmente dilatante até o final do ensaio.

As envoltórias, não reforçada e reforçada, de tensão cisalhante vs. tensão normal utilizadas para calcular os parâmetros de resistência dos ensaios de cisalhamento direto convencional e de plano cisalhado com superfície polida são mostradas nas Figuras 5.51(a) e (b), respectivamente.

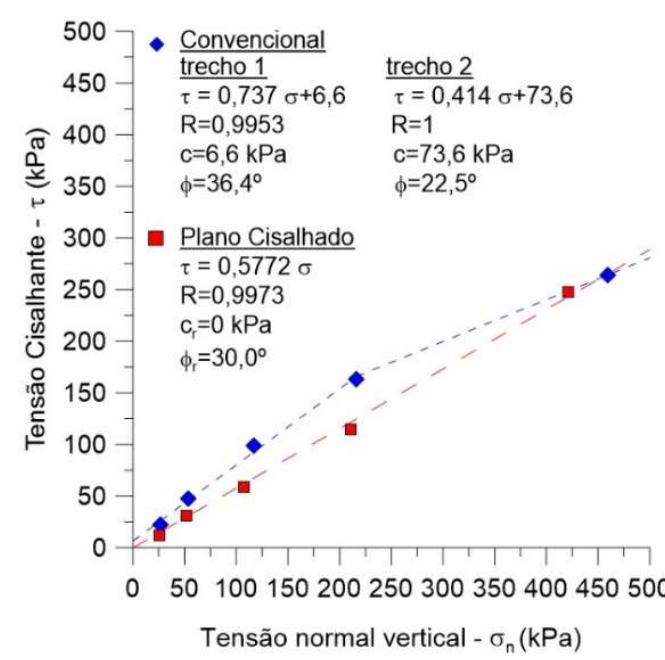

(a)

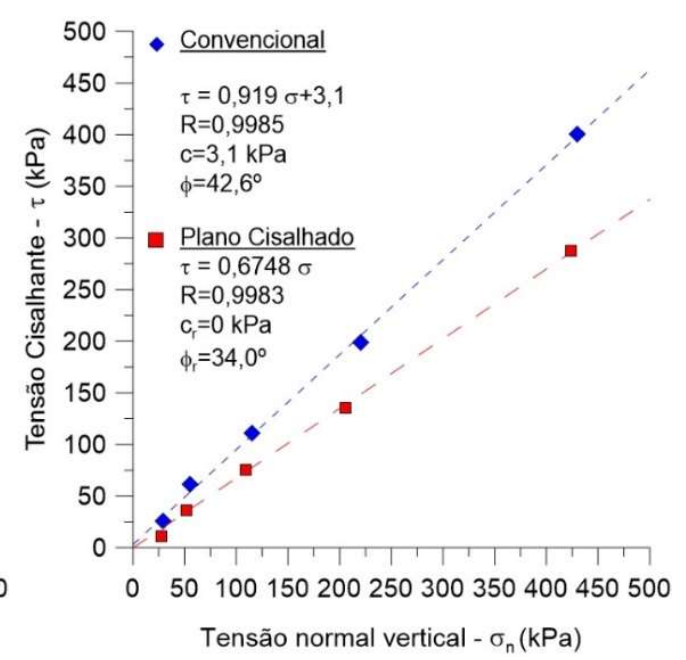

(b)

Figura 5.51. Resultados do cisalhamento direto (RMAu)

Rejeito de Minério de Ouro

(a) não reforçado (b) reforçado 
No ensaio convencional, a envoltória linear do rejeito de minério de ouro não reforçado, apresenta dois trechos diferentes que foram verificados por repetições de ensaios sobretudo na tensão de $400 \mathrm{kPa}$. Nota-se uma queda no ângulo de atrito nas tensões maiores a $200 \mathrm{kPa}$. O comportamento é bem representado por uma envoltória de resistência polinomial de segundo grau, como mostra a Figura 5.52.

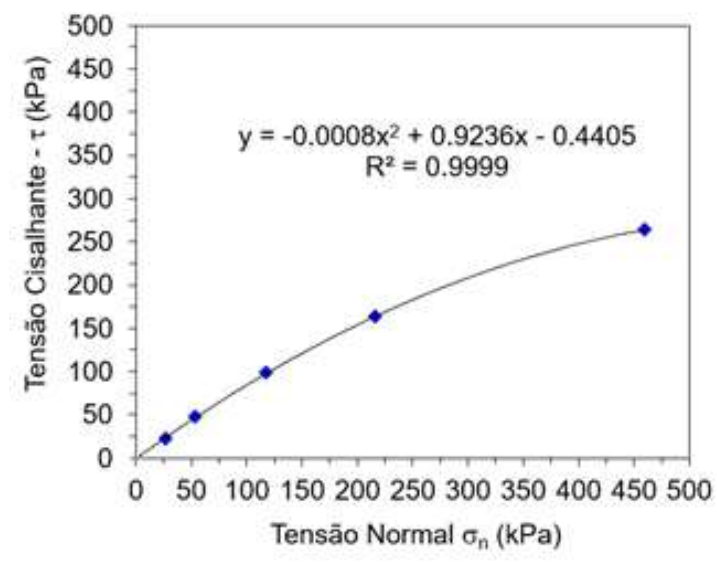

Figura 5.52. Envoltória polinomial não reforçada (RMAu)

Rejeito de Minério de Ouro

O rejeito de minério de ferro não reforçado representado com uma envoltória polinomial apresenta um intercepto coesivo zero e um ângulo de atrito que varia entre $22,5^{\circ}$ a $36,4^{\circ}$. No caso reforçado, existe um comportamento isotrópico no rejeito para todas as tensões aplicadas que é bem representada por uma envoltória linear como mostra a Figura 5.51(b), portanto os parâmetros de resistência do rejeito de minério de ouro reforçado apresentam um intercepto coesivo de $3 \mathrm{kPa}$ e um ângulo de atrito de $42,6^{\circ}$.

No caso dos ensaios de plano cisalhado com superfície polida, as correlações lineares foram superiores a 0,99 , mostrando que não existe uma significativa distinção entre o comportamento de baixas (até $100 \mathrm{kPa})$ e altas (>100 kPa) tensões.

No caso não reforçado e reforçado não existe intercepto coesivo mostrando a condição de cisalhamento prévio. $\mathrm{O}$ ângulo de atrito residual não reforçado é de $30^{\circ}$, enquanto o rejeito de ouro reforçado apresenta $34^{\circ}$ mostrando que as fibras de polipropileno acrescentam este parâmetro de resistência na condição residual.

Pelos resultados comprova-se a eficiência da fibra ainda existindo um cisalhamento prévio. 


\section{3. \\ Discussão dos Resultados}

Nos itens anteriores foram apresentados os resultados dos ensaios de caracterização física e mecânica feitos nos rejeitos de minério de ferro e ouro, não reforçado e reforçados. Neste item apresenta-se a discussão geral desses resultados, adicionalmente realizam-se comparações com os resultados de outras pesquisas, não necessariamente ligados ao comportamento de rejeitos de mineração, pelo escasso material bibliográfico, mas sim ao comportamento esperado em solos granulares e argilosos.

\subsection{1.}

\section{Variação dos Parâmetros de Resistência}

Mediante ensaios triaxiais e de cisalhamento direto, a literatura mostrou o incremento da resistência ao cisalhamento de pico e a redução da queda pós pico em areias, argilas e solos residuais reforçados com fibras sintéticas (Gray \& Ohashi, 1983; Freitag, 1986; Gray \& Maher, 1989; Bueno et al., 1996; Nataraj et al., 1996; Teodoro \& Bueno, 1998; Teodoro, 1999; Feuerharmel, 2000; Casagrande, 2001; Casagrande \& Consoli, 2002; Casagrande, 2005; Costas et al., 2013; Eldesouky et al., 2016), fato que é apresentado também nos rejeitos de minério de ferro e ouro.

Tabela 5.25. Variação no Ângulo de atrito

\begin{tabular}{lcccc}
\hline \multicolumn{1}{c}{ Rejeito de minério } & \multicolumn{2}{c}{ Ferro } & \multicolumn{2}{c}{ Ouro } \\
\hline \multirow{2}{*}{ Ensaio } & $\begin{array}{c}\phi^{\prime}\left({ }^{\circ}\right) \\
\text { Não reforçado }\end{array}$ & $\begin{array}{c}\phi^{\prime}\left(^{\circ}\right) \\
\text { Reforçado }\end{array}$ & $\begin{array}{c}\phi^{\prime}\left({ }^{\circ}\right) \\
\text { Não reforçado }\end{array}$ & $\begin{array}{c}\phi^{\prime}\left({ }^{\circ}\right) \\
\text { Reforçado }\end{array}$ \\
\hline Triaxial CD & 33,3 & 39,4 & 33,5 & 37,5 \\
Triaxial CU & 33,4 & 42,6 & 33,6 & 37,2 \\
Crítico & 33,8 & - & 32,5 & - \\
Transformação de fase CU & 27,5 & 28,3 & 25,9 & 26,8 \\
Cisalhamento direto & 32,8 & 37,7 & 36,4 & 42,6 \\
Cisalhamento direto residual & 27,3 & 33,7 & 30,0 & 34,0 \\
\hline
\end{tabular}

Tabela 5.26. Variação no Intercepto coesivo

\begin{tabular}{|c|c|c|c|c|}
\hline Rejeito de minério & & & & \\
\hline Ensaio & $\begin{array}{c}\mathrm{c}^{\prime}(\mathrm{kPa}) \\
\text { Não reforçado }\end{array}$ & $\begin{array}{c}\mathrm{c}^{\prime}(\mathrm{kPa}) \\
\text { Reforçado }\end{array}$ & $\begin{array}{c}c^{\prime}(\mathrm{kPa}) \\
\text { Não reforçado }\end{array}$ & $\begin{array}{c}\mathrm{c}^{\prime}(\mathrm{kPa}) \\
\text { Reforçado }\end{array}$ \\
\hline Triaxial CD & 28,3 & 103,0 & 14,4 & 60,0 \\
\hline Triaxial CU & 25,9 & 27,2 & 14,3 & 62,3 \\
\hline Cisalhamento direto & 0,0 & 4,5 & 6,6 & 3,1 \\
\hline
\end{tabular}

As Tabelas 5.25 e 5.26 mostram o ângulo de atrito e intercepto coesivo obtidos durante o desenvolvimento deste trabalho, a adição de fibra incrementou 
em todos os casos os valores. Nota-se uma diferença desprezível entre os parâmetros não reforçados, em contraste, com a diferença entre os parâmetros reforçados.

As Tabelas mostram um significativo incremento no ângulo de atrito, em todos os ensaios, e no intercepto coesivo na maioria de ensaios, com exceção do cisalhamento direto que mostrou uma leve redução do valor no rejeito de minério de ouro. Teodoro (1999) e Casagrande (2001) avaliaram areias siltosas reforçadas com fibras de polipropileno mostrando um incremento na parcela coesiva sem alterações significativas no ângulo de atrito, comparado com o rejeito de minério de ferro que classifica como areia siltosa, os resultados não concordariam, mas tomando em conta a procedência do material o comportamento pode se manifestar diferente.

Os resultados mostram também que as fibras incrementam a resistência residual dos rejeitos de minério de ferro e ouro. Não se encontraram pesquisas sobre a resistência residual em rejeitos de mineração, mas os resultados concordam com o trabalho de Costas et al., (2013), que estudou areias com diferentes tamanhos de grãos reforçadas com fibras de polipropileno, mostrando uma melhoria significativa na resistência residual de areias finas em estado medianamente denso.

\subsection{2.}

\section{Variação do Comportamento Volumétrico}

Com relação às deformações volumétricas drenadas, as amostras não reforçadas exibiram um comportamento dilatante a partir da faixa de 0,50-1,30\%, e nas amostras reforçadas, na faixa de $0,45-1,75 \%$. Na tendência volumétrica não drenada, as amostras suprimiram a tendência contrativa a partir da faixa $0,20-$ $1,00 \%$ não reforçada e $0,40-0,65 \%$ reforçada.

Em contraste, nos ensaios de cisalhamento direto convencional, as amostras não reforçadas apresentaram comportamento contrativo ao longo do ensaio, enquanto nas amostras reforçadas, o comportamento mudou para dilatante coincidindo com a resposta triaxial.

Os ensaios drenados realizados por Rezende (2013), sobre um rejeito de minério de ferro obtido de um dique de alteamento, mostram um comportamento inicialmente contrativo que a partir de $2 \%$ de deformação axial muda para dilatante, coincidindo plenamente com os resultados obtidos neste trabalho. 
Sobre comportamento reforçado do rejeito de minério de ferro com fibras de polipropileno, não se encontrou informação. Coelho (2008) reforçou rejeito de minério de ferro com fibras de polipropileno mas o teor de rejeito foi de $10 \%$ misturado com argila (20\%) e rejeito de jigagem (70\%), portanto não se consideram seus resultados, além que a resposta encontrada foi similar.

Revisou-se na literatura o comportamento de areias siltosas naturais reforçadas com fibras de polipropileno. Feuerharmel (2000) realizou o reforço com fibras de $12 \mathrm{~mm}$ e $36 \mathrm{~mm}$, mostrando que a inclusão de fibras aumenta a compressibilidade inicial do material coincidindo com este trabalho, não obstante, não encontrou uma mudança do comportamento volumétrico contrativo para dilatante como apresenta o rejeito de minério de ferro reforçado.

Outros autores também mostram o incremento do comportamento contrativo inicial em areias uniformes (Shewbridge \& Sitar, 1989; Stauffer \& Holtz, 1996; Bueno et al., 1996; Nataraj et al., 1996; Eldesouky et al., 2016). Sobre a mudança da tendência volumétrica não drenada em rejeitos fibroreforçados não se encontrou informação na literatura.

\subsection{3.}

\section{Variação da Energia de deformação}

Observou-se um aumento da energia de deformação acumulada com a adição de fibra na condição drenada e não drenada, mostrando que fibras influem na tenacidade dos rejeitos em todos os níveis de tensão média efetiva, os resultados concordam com a literatura que avaliou areias, argilas e solos residuais reforçados com fibras sintéticas (Freitag, 1986; Montardo, 1999; Montardo et al., 2002; Consoli et al., 2002; Consoli et al., 2004).

\subsection{4.}

\section{Variação nos Parâmetros de deformabilidade}

Avaliou-se a variação do módulo de deformabilidade $\left(\mathrm{E}_{50}\right)$ e da relação de deformações dos rejeitos não reforçados e reforçados, encontrando comportamentos diferentes.

No rejeito de minério de ferro, a adição de fibra reduziu o $\mathrm{E}_{50}$ drenado em todas as tensões efetivas de confinamento. Na condição não drenada, o $\mathrm{E}_{50}$ não 
reforçado reduziu com respeito ao valor drenado enquanto o $\mathrm{E}_{50}$ reforçado manteve seu valor.

No caso do rejeito de minério de ouro, sob condições drenadas e não drenadas, todos os valores do $E_{50}$ são maiores no caso não reforçado mostrando que a fibra reduz o módulo de deformabilidade.

Ambos os resultados são compatíveis com os resultados apresentados por Feuerharmel (2000), que trabalhou com argilas e areias siltosas reforçadas com fibras de polipropileno e concluiu que a adição de fibras aleatórias provocou reduções no módulo de deformabilidade da matriz. O resultado não reportado foi que fibras mantém o módulo de deformabilidade reforçado em condições drenadas e não drenadas. Ulbrich (1997) também observou uma redução do módulo com a inclusão de fibras.

A variação da relação de deformações no rejeito de minério de ferro, mostrou que, no início do ensaio, o reforço incrementou a relação de deformações, indicando que fibras aumentam as deformações laterais da matriz, posteriormente, o aumento da deformação axial e tensões desviadoras melhoram a interação fibra-grão e as fibras começam a permanecer presas no entrosamento do rejeito segurando os grãos e reduzindo as deformações laterais, fazendo que a relação de deformações seja menor do que não reforçado.

No rejeito de minério de ouro, a adição de fibra antes e depois da ruptura da matriz aumenta a relação de deformações tornando o compósito mais instável incrementando as deformações radiais.

A diferença entre estes comportamentos baseia-se na interação da interfase fibra-matriz. O aporte das fibras está na capacidade de absorver as tensões de tração, por isso depende do entrosamento do rejeito. O rejeito de minério de ferro e ouro são de matriz granular e fina, respectivamente, por conseguinte, o entrosamento de grãos somente aparece no rejeito de minério de ferro. No rejeito de minério de ouro, fibras se encontram "envolvidas" na matriz fina e incrementam as deformações laterais por não existir entrosamento.

Os resultados concordam com Feuerharmel (2000), que concluiu que, para solos não cimentados, as fibras constituem uma estrutura entrelaçada que impõe uma resistência às deformações radiais na matriz, enquanto para solos cimentados, as deformações se concentram somente na superfície de ruptura e a redistribuição 
das fibras causam um aumento nas deformações de expansão aumentando as deformações laterais.

\subsection{5.}

\section{Variação da rigidez}

Os ensaios realizados no rejeito de minério de ferro mostraram que rupturas drenadas e não drenadas se deram na faixa de 1,25-3,35 \% de deformação axial, a adição de fibras adiou o começo da fissuração para a faixa de 1,85-9,00 \%.

No rejeito de minério de ouro, rupturas foram dadas na faixa de 1,50-7,55 \%, enquanto no caso reforçado, o começo da fissuração foi entre 4,8-8,0\% de deformação axial. Ambos os resultados mostram que rejeitos reforçados apresentam um comportamento mais dúctil.

No ensaio drenado, o módulo cisalhante do rejeito de minério foi zero em $2 \%$ de deformação axial, e reforçado em $5 \%$, no ensaio não drenado em $3 \%$ não reforçado e em $9 \%$ reforçado. No rejeito de minério de ouro drenado, reduziu até zero em 3\% e reforçado não reduziu até zero, mas o valor mínimo situou-se em $8 \%$ de deformação axial, na condição não drenada, nos casos não reforçados e reforçados não reduziu até zero, mas os pontos mínimos situaram-se em 10\% e 20\% de deformação axial, respectivamente.

A literatura mostra que a adição de fibra reduz a rigidez inicial da matriz (Michalowski \& Cermák, 2003; Casagrande, 2005), os resultados concordam com Feuerharmel (2000) que avaliou a alteração da rigidez em argila e areia siltosa reforçadas com fibras de polipropileno indicando que existe uma grande redução do módulo. Festugato et al., (2015) trabalhou com rejeitos de minério de ouro e também encontrou que, sob condições de cisalhamento monotônicas, as adições de fibras reduziram a rigidez da matriz.

\subsection{6.}

\section{Variação da taxa de dilatância}

Observa-se que, em ambos os tipos de rejeitos de minério, a adição de fibra aumenta a razão de tensões q/p', principalmente para tensões efetivas médias baixas. Valores calculados, pela equação que relaciona a taxa de dilatância com a razão de tensões, são inferiores aos observados nos rejeitos reforçados. Heineck (2002) e Casagrande (2005) observaram este comportamento, mas em solos 
residuais de arenito reforçados com fibras de polipropileno. O comportamento contrativo é suprimido para todos os níveis de tensão efetiva de confinamento.

No rejeito de minério de ferro reforçado nota-se um incremento da tendência dilatante do rejeito, enquanto no rejeito de minério de ouro, observa-se a estabilização na taxa de dilatância com valor zero, o que mostra a supressão do comportamento contrativo até o final do ensaio. Não se encontraram pesquisas sobre este assunto na literatura.

\subsection{7.}

\section{Variação do excesso de poropressão}

As Figuras 5.53 e 5.54 mostram a variação do excesso de poropressão normalizada máxima e mínima para cada tensão efetiva de confinamento do rejeito de minério de ferro e ouro, respectivamente.
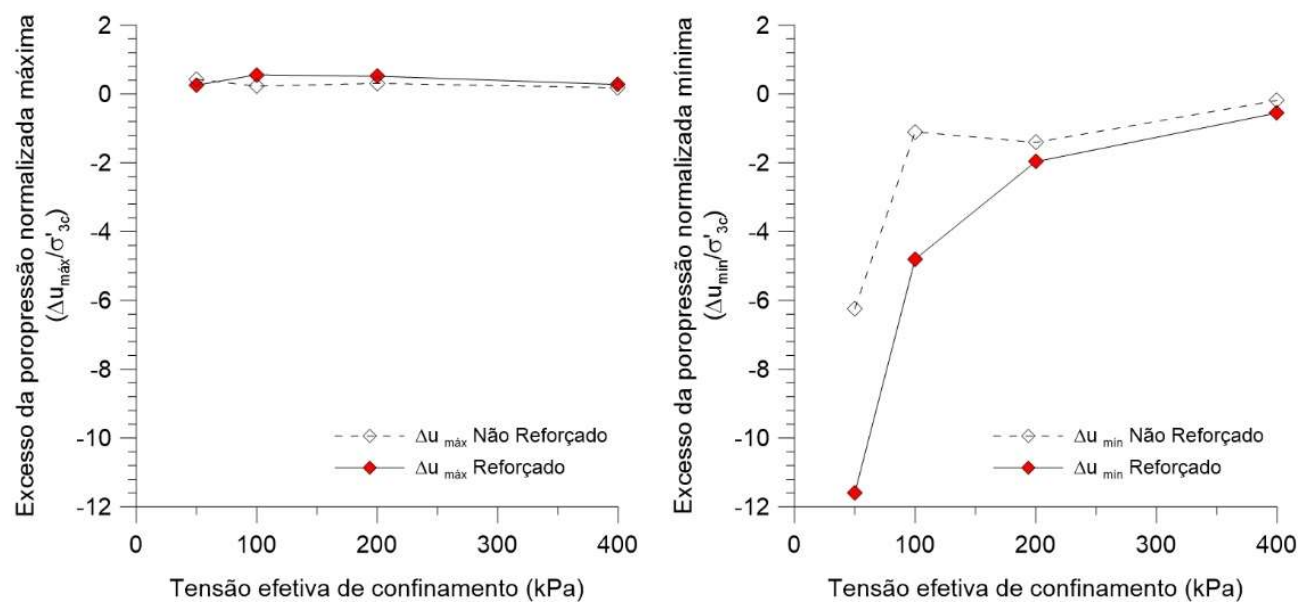

Figura 5.53. Variação do excesso de poropressão normalizada (RMFe)

Rejeito de Minério de Ferro
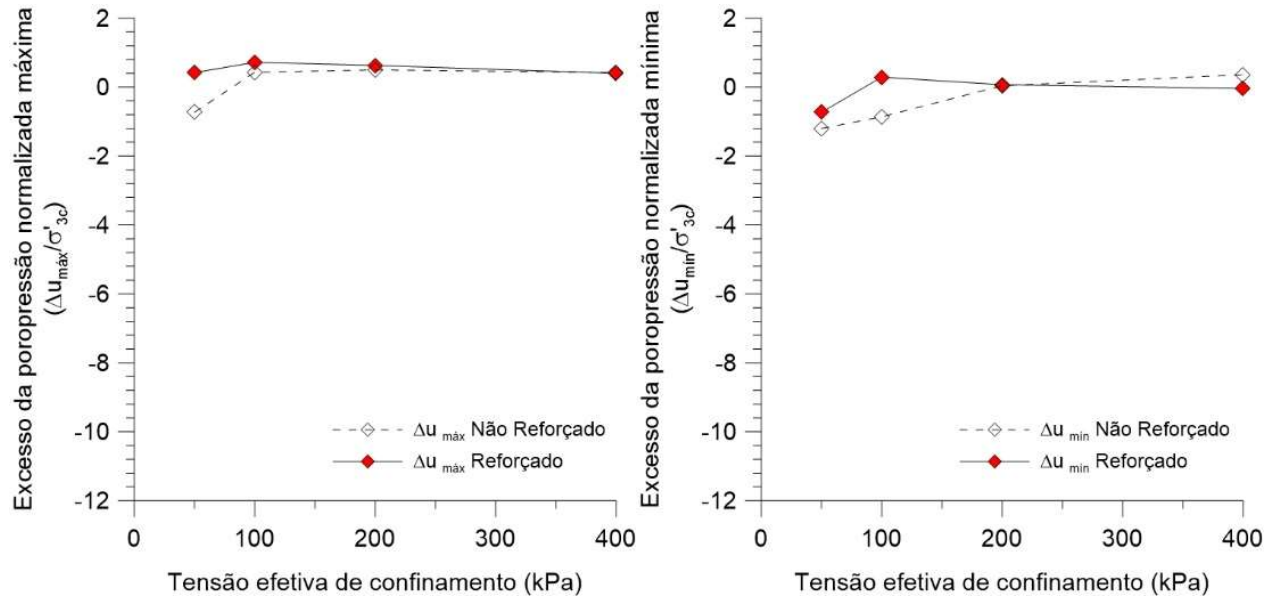

Figura 5.54. Variação do excesso de poropressão normalizada (RMAu)

Rejeito de Minério de Ouro 
A mínima poropressão em todos os casos se alcançou ao final do ensaio em $20 \%$ de deformação axial. No rejeito de minério de ferro, a máxima poropressão situou-se na faixa de $0,20-1,45 \%$ e reforçado entre $0,40-1,15 \%$, enquanto no rejeito de minério de ouro, situou-se na faixa de 1,0-2,5\% e reforçado entre 2,0 e 4,5\%. Em ambos os rejeitos, a adição de fibra incrementou a poropressão máxima normalizada no início do ensaio. Na Figura 5.53, nota-se que no rejeito de minério de ferro existe um acréscimo na poropressão pela adição da fibra que se reduz com o aumento da tensão efetiva de confinamento, mas que comparado com a poropressão mínima ao final do ensaio é insignificante. Após a ruptura, a adição de fibra diminui a poropressão de forma considerável, mas o efeito se reduz com o aumento da tensão efetiva de confinamento.

A Figura 5.54, mostra que o rejeito de minério de ouro também apresenta um incremento na poropressão com a adição da fibra mas o efeito é suprimido com o aumento da tensão efetiva de confinamento.

A análise da linha de transformação de fase não drenada mostrou que inicialmente a tendência volumétrica de ambos os rejeitos é contrativa, por conseguinte a fibra contribui à compressão, fibras aleatoriamente distribuídas geram um entrelaçado dentro na matriz, se esticando durante o carregamento, gerando uma compressão adicional à matriz que, sob condições não drenadas, incrementa a poropressão.

A diferença é que com a adição da fibra o rejeito de minério de ferro incrementa a tendência dilatante da matriz porque as fibras esticadas envolvem os grãos, diminuem as deformações laterais e suportam uma maior tensão desviadora o que incrementa a tendência da matriz, enquanto no rejeito de minério de ouro as fibras esticadas aumentam as deformações laterais incrementando a tendência contrativa da matriz até certo ponto depois do qual a tendência volumétrica não varia.

A estabilidade da tendência volumétrica no rejeito de minério de ouro reforçado foi verificada nos ensaios drenados mediante a Figura 5.29(b) que mostra o comportamento q/p' vs. taxa da dilatância, e nos ensaios não drenados na Figura 5.45(b), que mostra o ângulo de atrito mobilizado vs. taxa de variação do excesso de poropressão normalizada, ambas as quais, mostram a tendência volumétrica segundo a condição de drenagem imposta. Não se encontraram reportes sobre isto. 


\section{4 . \\ Exemplo de aplicação}

O reforço de fibras de polipropileno pode ser aplicado em taludes de pilhas de rejeitos filtrados e compactados para reduzir a superfície de ruptura crítica da estrutura. Como exemplo de aplicação, realiza-se a análise de estabilidade de um talude com inclinação 1,5H:1,0V (horizontal:vertical) pertencente a uma pilha de rejeitos de minério de ouro, filtrados e compactados, de 10 metros de altura.

A figura 5.55 mostra a análise de estabilidade de um talude não reforçado, utilizando diferentes métodos de equilíbrio limite para determinar o fator de segurança crítico $\mathrm{FS}=1$. Observa-se que a superfície de ruptura crítica mais afastada da face do talude se encontra 6,0 metros no interior da estrutura.

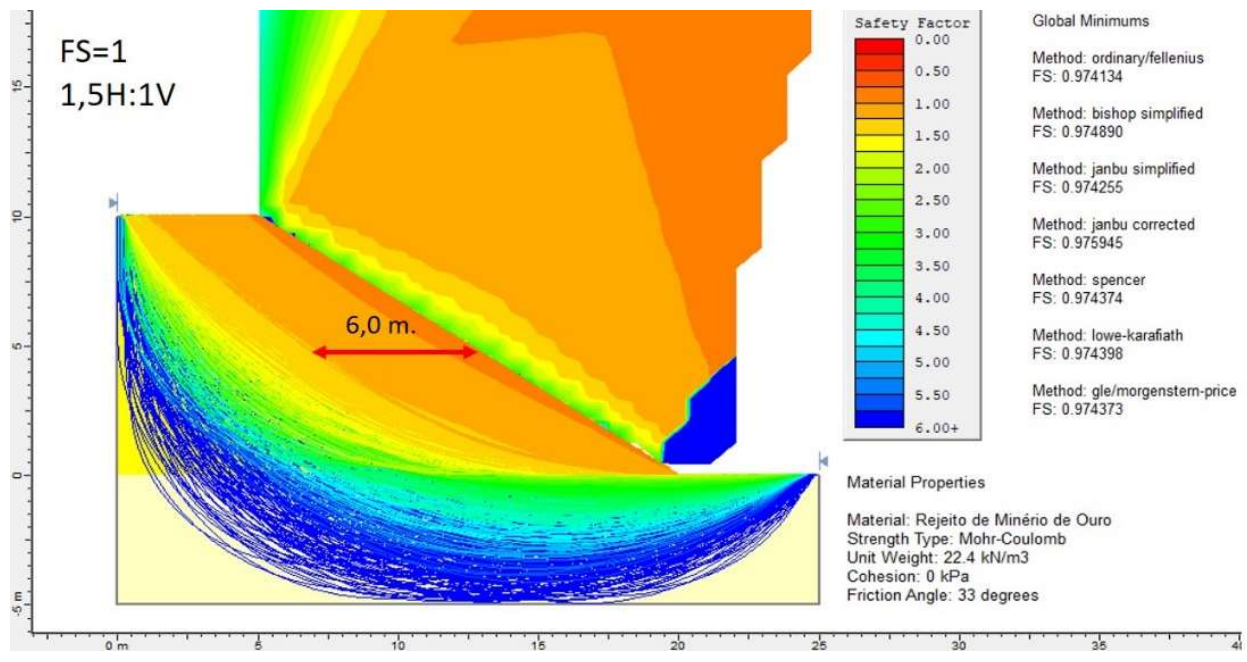

Figura 5.55. Análise de Estabilidade 1,5H:1V - não reforçado Rejeito de Minério de Ouro

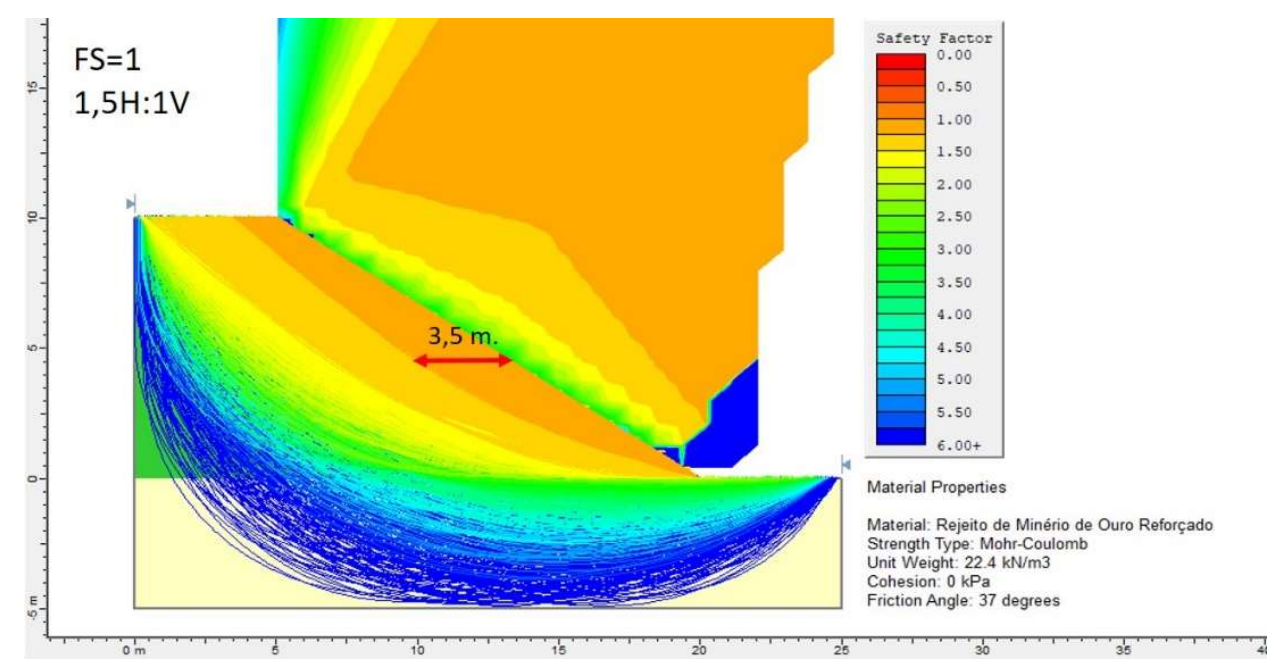

Figura 5.56. Análise de Estabilidade 1,5H:1V - reforçado Rejeito de Minério de Ouro 
A Figura 5.56 mostra a análise de estabilidade no talude reforçado. Nota-se que a superfície de ruptura crítica mais afastada, da face do talude reforçado, se encontra 3,5 metros no interior da estrutura.

No sentido de fazer uma análise conservadora, a coesão para os rejeitos não reforçados e reforçados foi considerada nula. Os ângulos de atrito não reforçado e reforçado foram os menores valores obtidos das envoltórias de resistência.

A adição de fibra reduz o risco de ruptura no interior da estrutura, sendo assim seria possível colocar um talude mais íngreme com a finalidade de compactar um maior volume de rejeitos. Realizou-se uma análise de estabilidade com talude 1,0H:1,0V. Os resultados se mostram na Figura 5.57.

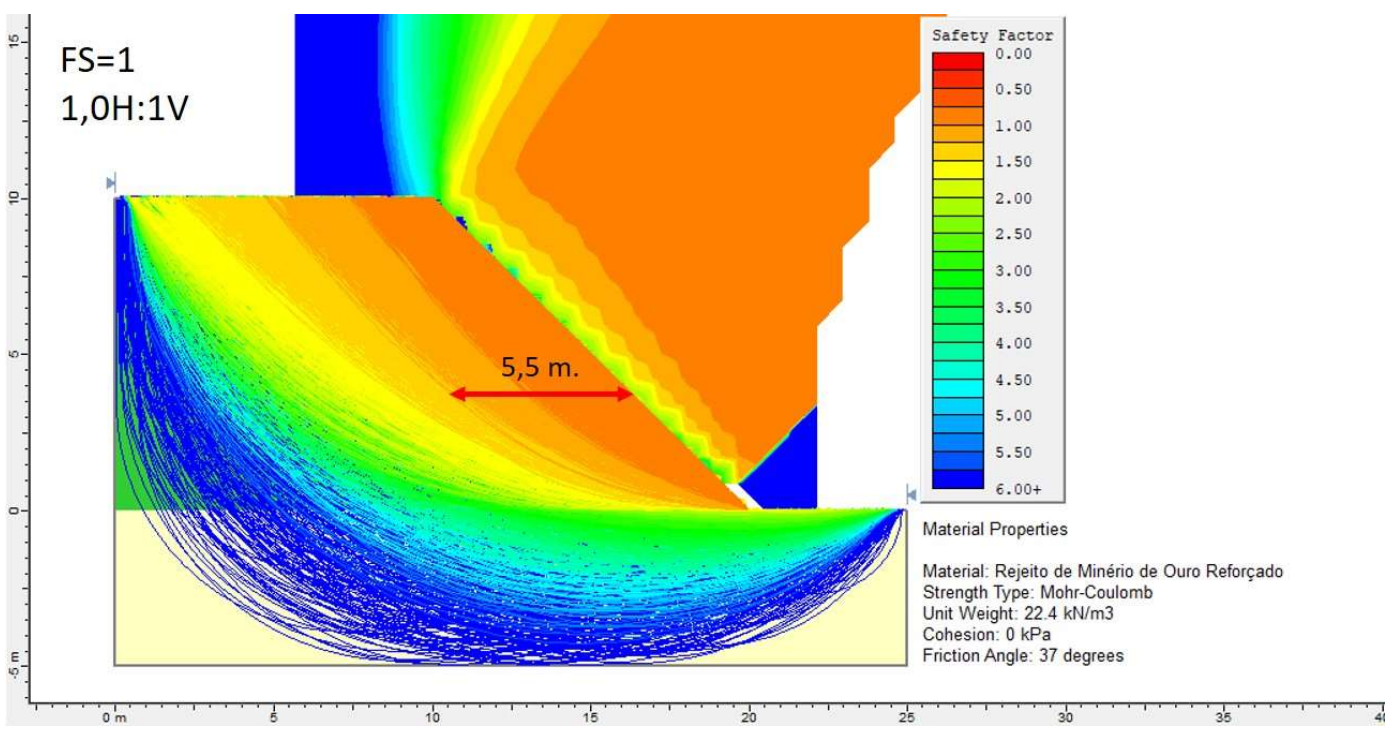

Figura 5.57. Análise de Estabilidade 1H:1V - reforçado Rejeito de Minério de Ouro

$\mathrm{Na}$ figura 5.57, nota-se que a superfície de ruptura crítica mais afastada da face do talude $1 \mathrm{H}: 1 \mathrm{~V}$ se encontra 5,5 metros no interior da estrutura, isto mostra que ainda com um talude mais íngreme a superfície de ruptura crítica é menor do que no caso não reforçado.

Se a pilha de rejeitos original de talude $1,5 \mathrm{H}: 1 \mathrm{~V}$ e de 10 metros de altura, tivesse o último aterro retangular de 20 metros de lado, o volume adicional que seria colocado pela adição da fibra com um talude de $1 \mathrm{H}: 1 \mathrm{~V}$, representaria o $28 \%$ do volume total. 


\section{6. \\ Conclusões e sugestões para trabalhos futuros}

O presente trabalho visou avaliar o efeito da inclusão de fibras de polipropileno em dois rejeitos de mineração de diferente granulometria e composição química. A avaliação centrou-se na influência sobre os parâmetros de resistência de pico e residual e a variação na tendência volumétrica drenada e não drenada. Para tal fim foram utilizados rejeitos de minério de ferro e ouro, procedentes de estruturas para armazenamento de rejeitos, um dique de alteamento de uma barragem de rejeitos e um aterro compactado, respectivamente. Estes rejeitos foram física e quimicamente caraterizados e submetidos a ensaios triaxiais drenados, não drenados e de cisalhamento direto convencional e de plano cisalhado com superfície polida. Os resultados foram comentados fazendo um comparativo entre a resposta da matriz granular do rejeito de minério de ferro com a resposta da matriz fina do rejeito de minério de ouro para entender os mecanismos de interação com a fibra. Neste capítulo apresentam-se as conclusões e sugestões, baseadas nas informações obtidas durante a realização do estudo.

\section{1.}

\section{Conclusões}

\subsection{1.}

\section{Caracterização dos rejeitos de mineração}

- Os rejeitos de minério de ferro (RMFe) e ouro (RMAu) são classificados pelo sistema SUCS como uma areia siltosa (SM) e uma argila siltosa de baixa plasticidade (CL-ML). A procedência dos rejeitos foi verificada mediante análises de fluorescência e os resultados do analisador de energia dispersiva (EDS).

- As curvas granulométricas e as análises MEV mostraram que, comparadas com o diâmetro da fibra, 95\% das partículas da matriz de RMFe são maiores que esse diâmetro, enquanto $80 \%$ das partículas da matriz de RMAu são menores. Portanto, no primeiro caso, a fibra forma parte do entrosamento do RMFe, 
ocupando espaços vazios e densificando a matriz, e em contraste no segundo caso, a fibra fica envolvida pela matriz de RMAu gerando maiores espaços na interfase com a matriz.

- Medições do potencial hidrogeniônico mostraram que o RMFe e RMAu possuem ph alcalino e ácido, respectivamente, portanto, fibras de polipropileno foram escolhidas como reforço discreto sintético pela resistência ao ataque álcali e resistência em ambientes com ácidos e sais.

\subsection{2.}

\section{Influência na resistência mecânica}

- Foram realizados ensaios triaxiais drenados e não drenados nos RMFe e RMAu não reforçados e reforçados sob tensões efetivas de confinamento de 50, 100, 200 e $400 \mathrm{kPa}$.

- Nos ensaios triaxiais drenados, RMFe e RMAu apresentaram um comportamento elasto-plástico com uma tensão de pico. A adição de fibra incrementou a resistência ao cisalhamento em ambos os rejeitos de minério, mas o comportamento do RMFe reforçado continuou elastoplástico enquanto o RMAu mudou para elastoplástico com enrijecimento (strain hardening).

- Ensaios triaxiais não drenados mostraram o mesmo comportamento do caso drenado no RMFe, diferente do RMAu não reforçado, que mostrou um comportamento de strain-hardening que foi significativamente amplificado com a adição de fibras.

- Ambos os rejeitos reforçados obtiveram um ganho de resistência mínimo equivalente ao dobro da tensão cisalhante não reforçada.

- Usando os ensaios drenados (CD) e não drenados (CU), a linha de estado crítico foi definida para o RMFe e RMAu, resultando valores de ângulo de atrito crítico de $33,8^{\circ}$ e $32,5^{\circ}$, respectivamente. A teoria do estado crítico aplicou-se aos ensaios reforçados para encontrar a suposta linha de estado crítico. Os resultados mostraram que o ângulo de atrito crítico seria maior com a adição da fibra. É importante dizer que não há marco teórico do estado crítico para solos reforçados com fibras.

- Parâmetros de resistência foram calculados no espaço s' vs. t', mostrando um incremento no ângulo de atrito de $33^{\circ}$ para $41^{\circ}$ no $R M F e$, e de $33^{\circ}$ para $37^{\circ}$ no 
RMAu. No caso do intercepto coesivo um maior acréscimo foi encontrado na condição drenada no RMFe de 28 a $103 \mathrm{kPa}$, enquanto sob condição não drenada o incremento é desprezível de 26 a $27 \mathrm{kPa}$. No RMAu, o incremento foi igual em ambas as condições de drenagem, de 14 para $60 \mathrm{kPa}$.

- Ensaios de cisalhamento direto convencional e de plano cisalhado com superfície polida foram realizados sob tensões normais verticais de 25, 50, 100, 200 e $400 \mathrm{kPa}$ em amostras submersas de RMFe e RMAu.

- O cisalhamento direto convencional mostrou que, com a adição de fibra, o ângulo de atrito incrementou de $32,8^{\circ}$ para $37,7^{\circ}$ no $R M F e$, e de $36,4^{\circ}$ para $42,6^{\circ}$ no RMAu. No intercepto coesivo com a adição de fibras, o RMFe mostrou um incremento zero para 4,5 $\mathrm{kPa}$, enquanto no RMAu observou-se um decréscimo de 6,6 para $3,1 \mathrm{kPa}$.

- No cisalhamento direto de plano cisalhado com superfície polida realizado para entender a resposta residual, apresentou-se um incremento no ângulo de atrito residual de $27,3^{\circ}$ para $33,7^{\circ}$ no $\mathrm{RMFe}$ e de $30^{\circ}$ para $34^{\circ}$ no RMAu. Pelos resultados comprova-se a eficiência da fibra ainda existindo um cisalhamento prévio.

- Observou-se um grande aumento da energia de deformação nas amostras reforçadas na condição drenada e não drenada em ambos os rejeitos de minério em todos os níveis de tensão efetiva de confinamento.

- A adição de fibras reduziu o módulo de deformabilidade de ambos os rejeitos de minério. Com o incremento das tensões efetivas de confinamento, o RMFe reforçado mostrou uniformidade no comportamento drenado e não drenado, enquanto no $\mathrm{RMFe}$ não reforçado o $\mathrm{E}_{50}$ drenado é maior do que o $\mathrm{E}_{50}$ não drenado, no caso do RMAu não reforçado sob condições drenadas e não drenadas todos o $\mathrm{E}_{50}$ foram maiores do que o caso reforçado.

- A adição de fibra reduz a rigidez inicial da matriz, o módulo cisalhante do RMFe e RMAu não reforçados reduziu o valor até zero em deformações axiais mínimas de 1,25 e 1,50\% respectivamente, enquanto a adição de fibra adiou a redução para 1,85 e 4,8\% de deformação axial. Ambos os resultados mostram o comportamento mais dúctil dos rejeitos reforçados. 


\subsection{2.}

\section{Influência no comportamento volumétrico}

- A variação volumétrica no RMFe foi dilatante e a adição da fibra aumentou este comportamento. No RMAu, o comportamento não reforçado foi dilatante, mas a adição da fibra mudou o comportamento para contrativo. As respostas obtidas têm a ver com o entrosamento das fibras com as matrizes de rejeitos.

- Nos ensaios drenados e não drenados é possível visualizar a evolução da tendência volumétrica mediante a relação entre a razão de tensões q/p' vs. taxa de dilatância $\left(\delta \varepsilon_{\mathrm{v}} / \delta \varepsilon_{\mathrm{s}}\right)$, e a relação entre o ângulo de atrito mobilizado ( $\phi$ 'mob.) vs. taxa de variação do excesso de poropressão normalizada $\left(\delta\left(\Delta \mathrm{u} / \sigma^{\prime}{ }_{\mathrm{c}}\right) / \delta \varepsilon_{\mathrm{a}}\right)$, respectivamente.

- No início do ensaio drenado, a relação de deformações do RMFe incrementa com adição de fibras, mostrando que o reforço aumenta as deformações laterais supõe-se que fibras impedem o normal rearranjo dos grãos, fazendo que rolem ao redor das fibras até encontrar o arranjo mais estável. Antes de atingir a estabilidade o comportamento é contrativo, com o incremento da deformação axial, se alcança a estabilidade estrutural do compósito e a interação fibra-grão é maior, então as fibras passam a ficar pressas entre os pontos de contato entre grãos se esticando com a deformação volumétrica e recebendo as tensões de tração dentro da matriz, até que os grãos de rejeito não suportam mais o incremento da tensão desviadora e começam a escorregar entre as fibras fazendo que a tensão desviadora diminua e a deformação volumétrica permaneça constante como mostra a tensão efetiva de confinamento de 400 $\mathrm{kPa}$, durante este processo, pelo acréscimo da tensão desviadora o comportamento se torna mais dilatante, este comportamento é verificado pela relação de tensões q/p' vs. $\delta \varepsilon_{\mathrm{v}} / \delta \varepsilon_{\mathrm{s}}$ que mostra o comportamento mais dilatante do RMFe com a adição da fibra.

- No caso não drenado, a adição de fibra incrementa a tendência contrativa inicial porque retarda o rearranjo dos grãos pela deformação axial e no processo as fibras ficam também presas entre os grãos se esticando lentamente e incrementando a poropressão até que os grãos escorregam produzindo a tendência dilatante e, por conseguinte, a queda de poropressão. Finalmente o ganho de resistência é a soma do aporte à resistência à tração das fibras mais a 
queda de poropressão, sendo maior a tensão desviadora máxima alcançada na condição não drenada do que drenada. Quando os grãos escorregam também se produz a estabilidade na tendência dilatante como mostram as curvas $\phi$ 'mob. vs. $\delta\left(\Delta \mathrm{u} / \sigma^{\prime}{ }_{c}\right) / \delta \varepsilon_{\mathrm{a}}$, na mudança da tendência volumétrica após a linha de transformação de fase.

- No RMAu, nota-se que, tanto na condição drenada e não drenada a tendência volumétrica inicial do rejeito é contrativa e depois passa levemente a dilatante, embora, em contraste com o RMFe, a adição de fibra não aumenta essa tendência, pelo contrário, a suprime.

- No RMAu, no início do ensaio drenado, a deformação axial produz a redução do índice de vazios até que a matriz alcança a tensão desviadora máxima, então a matriz não resiste mais tensão e dilata, enquanto o comportamento plástico manifesta-se na curva q vs. $\varepsilon_{\mathrm{a}}$ até o final do ensaio.

- A adição de fibras incrementa a porosidade do RMAu porque a fibra tem um diâmetro maior do que as partículas finas da matriz, deste modo, os vazios que poderiam ser ocupados por partículas finas permanecem na interfase fibramatriz. Durante a deformação axial, diminui o índice de vazios e o comportamento inicial contrativo é ampliado pela presença da fibra. No transcurso deste processo, fibras resistem forças de tração conseguindo que a matriz suporte uma maior tensão desviadora. No caso não reforçado, as deformações de ruptura primeiro são dadas na superfície de cisalhamento, no caso reforçado as fibras distribuem as tensões não gerando um plano de ruptura, portanto, o comportamento contrativo continua até permanecer constante, enquanto a curva q vs. $\varepsilon_{\mathrm{a}}$ mostra um comportamento de strain hardening até o final do ensaio.

- Na condição não drenada, no início do ensaio, fibras incrementam ligeiramente a poropressão mas esse incremento se reduz com o aumento da tensão efetiva de confinamento, portanto, o ganho em resistência não drenada é pelo aporte da fibra na tração do compósito e não pela redução de poropressão como no RMFe. No RMAu não reforçado, as curvas $\phi{ }^{\prime}$ mob. vs. $\delta\left(\Delta \mathrm{u} / \sigma^{\prime}{ }_{\mathrm{c}}\right) / \delta \varepsilon_{\mathrm{a}}$, mostraram a tendência contrativa inicial da matriz mudando levemente para dilatante após a linha de transformação de fase, embora, no rejeito reforçado, a tendência contrativa é suprimida mas não chega a ser dilatante. 


\section{2 .}

\section{Sugestões para trabalhos futuros}

As seguintes recomendações podem ser feitas para futuras pesquisas:

- Avaliar o comportamento dos dois rejeitos de mineração aqui apresentados, submetidos a grandes deformações mediante ensaios ring shear, com a finalidade de verificar se existe uma deformação plástica nas fibras porque a interação da fibra com matrizes granulares e finas é diferente.

- Para verificar a susceptibilidade à liquefação estática, recomenda-se realizar ensaios triaxiais com carregamento cíclico e medição de poropressão a meia altura do corpo de prova.

- Realizar ensaios de envelhecimento de fibras de polipropileno imersas nas matrizes de rejeito de minério de ferro e ouro com a finalidade de observar se existe perda de resistência à tração.

- Realizar ensaios de arrancamento (pull out) de fibras de polipropileno nas matrizes de rejeito estudadas para obter a resposta ao arrancamento segundo o nível de tensão de confinamento o que poderia oferecer maiores luzes sobre a interface fibra-matriz.

- Realizar ensaios de carga em placa realizando um aterro experimental instrumentado reforçado com fibras de polipropileno aleatoriamente distribuídas.

- Desenvolver um modelo de previsão do comportamento mecânico e volumétrico dos compósitos de rejeito fibro-reforçado visando a simulação numérica. 


\section{7. \\ Referências bibliográficas}

ABNT - ASSOCIAÇÃO BRASILEIRA DE NORMAS TÉCNICAS. Solo Amostra de Solos - Preparação para ensaios de compactação e caracterização. NBR-6457, 1986a.

ABNT - ASSOCIAÇÃO BRASILEIRA DE NORMAS TÉCNICAS. Solo - Ensaio de Compactação. NBR-7182, 1986 b.

ABNT - ASSOCIAÇÃO BRASILEIRA DE NORMAS TÉCNICAS. Solo Análise granulométrica - NBR-7181, 1984a.

ABNT - ASSOCIAÇÃO BRASILEIRA DE NORMAS TÉCNICAS. Solo Determinação do limite de liquidez -NBR-6459, 1984b.

ABNT - ASSOCIAÇÃO BRASILEIRA DE NORMAS TÉCNICAS. Solo Determinação do limite de plasticidade - NBR-7180, 1984c.

ABNT - ASSOCIAÇÃO BRASILEIRA DE NORMAS TÉCNICAS. Grãos de solos que passam na peneira de $\mathbf{4 , 8} \mathbf{~ m m}$ - Determinação da massa específica NBR-6508, 1984d.

ABNT - ASSOCIAÇÃO BRASILEIRA DE NORMAS TÉCNICAS. Solo Determinação do índice de vazios máximo. - NBR-12004, 1990.

ABNT - ASSOCIAÇÃO BRASILEIRA DE NORMAS TÉCNICAS. Solo Determinação do índice de vazios mínimo. - NBR-12051, 1991.

ABNT - ASSOCIAÇÃO BRASILEIRA DE NORMAS TÉCNICAS. Solo Determinação do coeficiente de permeabilidade de solos granulares à carga constante. - NBR-13292, 1995.

ANGeliM, R. R. Desempenho de Ensaios Pressiométricos em Aterros Compactados de Barragens de Terra na Estimativa de Parâmetros Geotécnicos. Tese de Doutorado, Publicação G.TD-067-1/11. Departamento de Engenharia Civil e Ambiental. Universidade de Brasília, Brasília, DF, 291 p.

AGNELLI N: ALBIERO, J. Aspectos físicos, químicos e mecânicos de um solo colapsível, inundado com diferentes líquidos. Solos e Rochas, Revista Brasileira de Geotecnia, v. 18, n. 1, p. 77-95, 1997.

ALBUQUERQUE L.H. Avaliação do comportamento geotécnico de barragens de rejeitos de minério de ferro a traves de ensaios de piezocone. Ouro Preto, 
2004. 213f. Dissertação (Mestrado em Engenharia) - Universidade Federal de Ouro Preto.

AL WAHAB, R.M.; AL-QURNA, H.H. Fiber Reinforced cohesive soils for application in compacted earth structures. GEOSSYNTHETICS'95 CONFERENCE. 1995, Nashville. Procedings. v.2, p.433-466, 1995.

ANAGNOSTOPOULOS A., PAPALIANGAS T., KONSTANTINIDIS D.,PATRONIS C. Shear Strength of Sands Reinforced with Polypropylene Fibers. Geotech Geol Eng (2013) 31:401-423.

ARAÚJO, C. B. Contribuição ao estudo do comportamento de barragens de rejeito de mineração de ferro. Rio de Janeiro, 2006. 133f. Dissertação (Mestrado em Engenharia) - Universidade do Rio de Janeiro.

ARENICZ, R. M. and CHOWDHURY, R. N. Laboratory Investigation of Earth Walls Simultaneously Reinforced by Strips and Random Reinforcement. Geotechnical Testing Journal. GTJODJ 1988; 11: 241-247.

ATKINSON, J.H. An introduction to the Mechanics of Soils and Foundations. London: McGraw-Hill, p. 337, 1993.

ATKINSON, J.H.; BRANSBY, P.L. The mechanics of soils - an introduction to crítical state soil mechanics. London: McGraw-Hill, 375p., 1978.

AUTORIDAD NACIONAL DEL AGUA (ANA). Inventario de Presas en el Perú Año 2015. Lima, 2016. 97p. Disponível em: http://www.ana.gob.pe/sites/default/files/publication/files/inventario de presas 0 . pdf. Data de Acesso em: 24 de abril de 2018.

BARBOSA, M.C., SANTOS, A.C.B. (2003). Aspectos Geotécnicos e Ambientais Associados a Rejeitos Finos com Elevado Teor de Água Inicial; Conferência, Proc. V Congresso Brasileiro de Geotecnia Ambiental (REGEO), Porto Alegre, RS; p.339-363.

BEDIN, J. Estudo do Comportamento Geomecânico de Resíduos de Mineração. Porto Alegre, 2010. 207f. Tese (Doutorado em Geotecnia) Universidad Federal do Rio Grande do Sul.

BEDIN, J.; GAUER, E.; LANGONE, M. (2008). Caracterização Geotécnica de Resíduos da Mineração de Ouro Através de Ensaios de Piezocone. XIV Congresso Brasileiro de Mecânica dos Solos e Engenharia Geotécnica, Búzios, Brasil.

BEHZAD AMIR-FARYAR and M. SHERIF AGGOUR. Effect of fiber inclusion on dynamic properties of clay. Geomechanics and Geoengineering, 2015. DOI: 10.1080/17486025.2015.1029013.

BENTUR A.; MINDESS S., Fibre reinforced cementitious composites. 2nd ed. Wiltshire, Cromwell Press, 625 p., 2007. 
BHARDWAJ K, MANDAL N. Study on polypropylene fiber reinforced fly ash slopes. In: 12th Int conf of int assoc for comp meth and advan in geomech (IACMAG), Goa, India; 2008.

BRIAUD, J.-L.: Introduction to Soil Moduli. Geotechnical News, June 2001, BiTech Publishers Ltd, Richmond, B.C., Canada.

BUENO, B.S.; LIMA, D.C.; TEIXEIRA, S.H.C.; RIBEIRO N.J. Soil fiber reinforcement: basic understanding. International Symposium on Environmental Geotechnology, 1996, San Diego. Anais. v.1, p. 878-884, 1996.

BUDINSKI, K.G. Engineering materials, properties and selection. 5ed. New Jersey: Prentice Hall International, 653p., 1996.

CASAGRANDE, M.D.T., Estudo do comportamento de um solo reforçado com fibras de polipropileno visando o uso como base de fundações superficiais. Porto Alegre, 2001, 95p. Dissertação (Mestrado em Geotecnia) - Programa de Pós Graduação em Engenharia Civil - Universidade Federal Rio Grande do Sul.

CASAGRANDE, M.D.T., Comportamento de solos reforçados com fibras submetidas a grandes deformações. Porto Alegre, 2005, 4-5p. Tese (Doutorado em Engenharia) - Programa de Pós Graduação em Engenharia Civil - Universidade Federal Rio Grande do Sul.

CASAGRANDE, M.D.T.; CONSOLI, N. Estudo do comportamento de um solo residual areno-siltoso reforçado com fibras de polipropileno. Solos e Rochas, São Paulo, ABMS/ABGE, v.25, n.3, p.223-230, 2002.

CAVALCANTE, A. L. B. Modelagem e simulação do transporte por arraste de sedimentos heterogêneos acoplado ao mecanismo de tensão deformaçãoporopressão aplicado a barragens de rejeito. Brasília, 2004. 297p. Tese (Doutorado em Engenharia) - Faculdade de Tecnologia, Universidade de Brasília.

CHEGENIZADEH A., KERAMATIKERMAN M. E NIKRAZ H. Liquefaction resistance of fibre reinforced low-plasticity silt. Soil Dynamics and Earthquake Engineering 104, 2018, 372-377.

COELHO E.F. Estudo do Comportamento Mecânico de Rejeitos de Minério de Ferro reforçados com Fibras de Polipropileno. Minas Gerais, 2008. 100p. Dissertação (Mestrado em Geotecnia) - Programa de Pós Graduação em Engenharia Civil - Universidade Federal de Ouro Preto.

CONSOLI, N.C.; CASAGRANDE, M.D.T.; COOP, M.R. Performance of a fibre reinforced sand at large shear strains. Geotecnique 57, 2007a, No. 00, 1-6.

CONSOLI, N.C.; CASAGRANDE, M.D.T.; TOMHÉ, A; DALLA ROSA e FAHEY. P Effect of relative density on plate loading tests on fiber-reinforced sand. Geotecnique 59, (2009) No. 5, 471-476. 
CONSOLI, N.; HEINECK, K. S.; CASAGRANDE, M.D.T.; AND COOP, M. R. Shear Strength Behavior of Fiber-Reinforced Sand Considering Triaxial Tests under Distinct Stress Paths. J Geotech Geoenviron Eng 2007b; 133: 1466.

CONSOLI, N.C.; MONTARDO, J.P.; PRIETTO, P.D.M.; PASA, G. Engineering behavior of a sand reinforced with plastic waste. Journal of Geotechnical and Geoenvironmental Engineering, New York, v.128, n.6, p. 462-472, 2002.

CONSOLI, N.C.; MOTARDO, J.P.; DONATO, M.; PRIETTO, P. D. M. Effect of material properties on the behaviour of sand-cement-fibre composites. Ground Improvement, ISSMGE, v.8 n.2, p.77-90, 2004.

CONSOLI, N.C.; NIERWINSKI, H.P.; SILVA, A.P. e SOSNOSKI J. Durability and strength od fiber-reinforced compacted gold tailings-cement blends. Geotextiles and Geomembranes 2017; 45: 98-102.

CONSOLI N. C.; VENDRUSCOLO M. A.; FONINIA A.; DALLA F. Fiber reinforcement effects on sand considering a wide cementation range. Geotext Geomembr 2009; 27:196-203.

CONSOLI, N. C.; VENDRUSCOLO M. A.; MARQUES P. D. Behavior of Plate Load Tests on Soil Layers Improved with Cement and Fiber. J. Geotech Geoenviron Eng 2003; 129: 96-101.

CONSORCIO MINERO HORIZONTE (CMH). Evaluación de las Actuales Condiciones del depósito de relaves filtrados Curaubamba y el estudio del recrecimiento de dicho depósito de relaves. Lima, Peru, 2014. 586 p.

COSTAS, A.; ANAGNOSTOPOULOS; THEODOSIOS T.; PAPALIANGAS; D. KONSTANTINIDIS; C. PATRONIS. Shear Strength of Sands Reinforced with Polypropylene Fibers. Geotechnical and Geological Engineering Volume 31, Issue 2, pp 401-423, 2013.

CUCCOVILLO, T.; COOP, M. R. The measurement of local axial strains in triaxial tests using LVDTs. Géotechnique, v.47, n.1, p. 167-171, 1997.

CURCIO, D. S., Comportamento de vigas de concreto armado reforçadas com fibras de carbono. Dissertação de mestrado. Universidade Federal Fluminense. Niterói, 2001.

CURCIO, D. S.; Comportamento hidromecânico de compósito solo-fibra. Rio de Janeiro, 2008. 169p. Tese (Doutorado em Engenharia) - Escola de Engenharia, Programa de Pós-graduação em Engenharia Civil da UFRJ.

DEPARTAMENTO NACIONAL DE ESTRADAS DE RODAGEM. Solos. Determinação da densidade real. DNER-ME 093/94.

DE CAMPOS, T.M.P. Características de Projeto e Dimensionamento de um Transdutor de Variação de Volume. Departamento de Engenharia Civil PUC/RJ. Relatório Interno, RI 07/85, 1985. 
DIAMBRA A., IBRAIM E, MUIR WOOD D, RUSSELL A. R. Fibre reinforced sands: Experiments and modelling. GEOTEXTILES AND GEOMEMBRANES 28 (2010) $238-250$.

DIAMBRA, A., \& IBRAIM, E. (2015). Fibre-reinforced sand:: interaction at the fibre and grain scale. Géotechnique, 65(4), 296-308. DOI: 10.1680/geot.14.P.206

DIAMBRA, A., IBRAIM, E., MUIR WOOD, D., RUSSELL, A.R. (2013). Fibre reinforced sands: from experiments to modelling and beyond. International Journal Numerical and Analytical Methods in Geomechanics 37, 2427-2455.

DIRECCIÓN GENERAL DE ASUNTOS AMBIENTALES MINEROS (DGAAM). Guía para el Manejo de Relaves Mineros. Lima, 2009. 73 p. Disponível em: http://www.minem.gob.pe/minem/archivos/file/DGAAM/guias/relaveminero.pdf. Data de Acesso em: 24 de abril de 2018.

DONATO, M. Medidas diretas de tensão em solo reforçado com fibras de polipropileno. Porto Alegre, 2007. 162p. Tese (Doutorado em Engenharia) Escola de Engenharia, Programa de Pós-graduação em Engenharia Civil da UFRGS.

DONATO, M.; FOPPA, D.; CERATTI, J. A. P.; CONSOLI, N. C. Fibras de polipropileno como reforço para materiais geotécnicos. Solos e Rochas, São Paulo, ABMS/ABGE, v.27, n.2, p. 161-179, 2004.

ELDESOUKY H., MORSY M. e MANSOUR M. Fiber-reinforced sand strength and dilation characteristics. Ain Shams Engineering Journal. 2016, N 7, 517 526.

EMBRAPA - Manual de métodos de Análise de solos, Centro Nacional de Pesquisa de Solos, Rio de Janeiro, 2da Ed., 1997.

ENDO, T., AND TSURUTA, T. The Effect of Tree Roots upon the Shearing Strength of Soil. Annual Report No. 18 of the Hokkaido Branch, Tokyo Forest Experiment Station, Tokyo, Japan; 1969, 168-179.

FESTUGATO, L., CONSOLI, N.C., FOURIE, A. Cyclic Shear Behaviour of Fibre Reinforced Mine Tailings. Geosynthetics International, 2015, 22 (2), 1-11.

FEUERHARMEL, M.R.; Comportamento de solos reforçados com fibras de polipropileno. Porto Alegre, 2000. 131p. Dissertação (Mestrado em Engenharia) Programa de Pós-Graduação em Engenharia Civil da UFRGS.

FREITAG, D.R. Soil randomly reinforced with fibers. Journal of Geotechnical Engineering, New York, v.112, n.8, p. 823-826, 1986. 
FUNDAÇÃO ESTADUAL DO MEIO AMBIENTE (FEAM). Inventário de barragem do Estado de Minas Gerais Ano 2017. Belo Horizonte, 2018. 40 p. Disponível

em: http://www.feam.br/images/stories/2018/BARRAGENS/Invent\%C3\%A1rio de Barragens 2017.pdf. Data de Acesso em: 24 de abril de 2018.

GARGA V. K., MCKAY L.D. Cyclic triaxial strength of mine tailings. Journal of Geotechnical Engineering., 1984, 110(8): 1091-1105.

GIACOMINI, N. P. Compósitos reforçados com fibras naturais para a indústria automobilística. Dissertação de Mestrado. Departamento de Engenharia de Materiais. Universidade de São Paulo, São Carlos, 2003.

GIBSON, R. E.; HENKEL, D. J. Influence of duration of tests at constant rate of strain on measured "Drained" strength. Géotechnique, v. 4, n. 1, p. 6-15, 1954.

GIRARDELLO, V. Ensaios de placa em areia não saturada reforçada com fibras. Porto Alegre, 2010. 141p. Dissertação (Mestrado em Engenharia) Programa de Pós- Graduação em Engenharia Civil da UFRGS.

GOMES, R. C.; OLIVEIRA FILHO, W.L; RIBEIRO, L.F.M. Laudo pericial da ruptura do dique de contenção de rejeitos de minério de ferro da cava $\mathrm{C} 1$ da Mineração Rio Verde Ltda., localizada no município de Nova Lima/MG. Ministério Público do Estado de Minas Gerais, Belo Horizonte, 2001. p. 22.

GONSALES G.L. Comportamento de um aterro experimental sobre um depósito de rejeitos de ouro - Mineração Paracatu. Rio de Janeiro, 2012. 226p. Tese (Doutorado em Engenharia) - Programa de Pós-graduação em Engenharia Civil da Pontifícia Universidade Católica do Rio de Janeiro.

GRAY, D.H.; AL-REFEAI, T. Behavior of fabric versus fiber-reinforced sand. Journal of Geotechnical Engineering, New York, v.112, n.8, p. 804-820, 1986.

GRAY, D.H.; MAHER, M.H. Admixture stabilization of sands with random fibers. INTERNATIONAL CONFERENCE ON SOIL MECHANICS AND FOUNDATION ENGINEERING, 12, 1989, Rio de Janeiro, Proceedings. Rotterdam: A.A. Balkema, v.2, p.1363-1366, 1989.

GRAY, H.; OHASHI, H. Mechanics of fiber reinforcement in sand. J. of Geotech Eng ASCE 1983; 109: 335-353.

HANNANT, L. Polymers and polymers composities. In: J.M. ILLSTON. Construction materials: their nature and behavior. 2ed., London: J.M. Illston/E \& FN Spon, p.359-403, 1994.

HEINECK, K.S. Estudo do comportamento hidráulico e mecânico de materiais geotécnicos para barreiras horizontais. Porto Alegre, 2002. 251p. Tese (Doutorado em Engenharia) - Programa de Pós-Graduação em Engenharia Civil da UFRGS. 
HEINECK, K.S.; CONSOLI, N.C. Influência da adição de fibras na resistência última de solos. CONGRESSO BRASILEIRO DE MECÂNICA DOS SOLOS E ENGENHARIA GEOTÉCNICA, 12, 2002, São Paulo. Anais. São Paulo: ABMS, 3v., v.1, p.403-408, 2002.

HOLLAWAY, L. Polymers and polymer composites. In: Construction Materials; their nature and behavior. London: J. M. Illston/E. \& F.N. Spon, 2ed., p.321-358, 1994.

HOMEM T.R. Comportamento de misturas asfálticas porosas com ligantes modificados por polímeros e adição de fibras. Porto Alegre, Tese Mestrado em Engenharia Civil da UFRGS, 109p., 2002.

ILLSTON, J.M. Construction materials; their nature and behavior. 2ed. London: E \& FN Spon, 518p., 1994.

INTERNATIONAL COMMISSION ON LARGE DAMS - ICOLD. Bulletin 121: Tailings Dams Risk of Dangerous Occurrences: Lessons Learnt from Practical Experiences. Paris, 2001. 239 p.

INSTITUTO BRASILEIRO DE MINERAÇÃO (IBRAM). Gestão e Manejo de Rejeitos na Mineração. Brasília, 2016. 128 p. Disponível em: http://www.ibram.org.br/sites/1300/1382/00006222.pdf. Data de Acesso: 24 de abril de 2018.

ISHIHARA, K., TATSUOKA, F. \& YASUDA, S. Undrained deformation and liquefaction of sand under cyclic stresses. Soils and Foundations, 1975, 15:1, 2944.

JEWELL, R.A.; WROTH, C.P. Direct shear tests on reinforced sand. Géotechnique, London, v.37, n.1, p.53-68, 1987.

LADE, P.V. Instability of sand in the Prefailure hardening regime. Proc. First Int. Conf. on Pre-Failure Deformation Characteristics of Geomaterials, 2, 1995, 837-854.

LADE, P. V., \& IBSEN, L. B. A Study of the Phase Transformation and the Characteristic Lines of Sand Behaviour. Aalborg: Geotechnical Engineering Group. AAU Geotechnical Engineering Papers: Soil Mechanics Paper, 1997, No. 12, Vol.. R 9702.

LAMBE, T. W. ET. WHITMAN, V. R.: Soil Mechanics. New York: John Wiley and Sons, 1969, 576 p. ISBN: 978-0-471-51192-2.

LEFLAIVE E. TEXSOL: Already more than 50 successful applications. In: Int sym on earth reinf, Fukuoka, Japan; 2001. 
LI, CH; ZORNBERG, J.G. Mobilization of Reinforcement Forces in FiberReinforced Soil. Journal of Geotechnical and Geoenvironmental Engineering, 2013.

LI W., CHAI S., ZHANG H., QIAN S. Mechanical properties of soil reinforced with both lime and four kinds of fiber. Construction and Building Materials, 172, 2018, 300-308.

LIRER, S; FLORA, A; CONSOLI, N.C. Experimental Evidences of the Effect of Fibers in Reinforcing a Sandy Gravel. Geotech Geol Eng (2012) 30:75-83.

MAHER, M.H.; GRAY, D.H. Static response of sands reinforced with randomly distributed fibers. Journal of Geotechnical Engineering, New york, v.116, n.11, p.1661-1677, 1990.

MAHER, M.H.; HO, Y.C. Behavior of fiber-reinforced cemented sand under static and cyclic loads. Geotechnical Testing Journal, Philadelphia, v.16, n.3, p.330-338, 1993.

MAHER, M.H.; HO, Y.C. Mechanical properties of Kaolinite/fiber soil composite. Journal of Geotechnical Engineering, New York, v.120, n.8, p. 13811393, 1994.

MAHIPAL S. C.; SATYENDRA M.; BIJAYANANDA M. Performance evaluation of silty sand subgrade reinforced with fly ash and fiber. Geotext Geomembr 2008; 429-435.

MARTINS, F.B.; BRESSANI, L.A.; COOP, M.R.; BICA, A.V.D. Some aspects of the compressibility behaviour of a clayey sand. Canadian Geotechnical Journal, Ottawa, v.38, n.6, p. 1177-1186, 2001.

MATTHEWS F.F and RAWLINGS R.D. Composite Materials: Engineering and Science, England, v.1, p 470, 1994.

MCGOWN, A.; ANDRAWES, K.Z.; HYTIRIS, N. MERCER, F.B. Soil strengthning using randomly distributed mesh elements. INTERNATIONAL CONFERENCE ON SOIL MECHANICS AND FOUNDATION ENGINEERING, 11., São Francisco, Proceedings... v.3, p.1735-1738, 1988.

McPHAIL, G. The high density thickened discharge tailings storage facility at Osborne Mine - a case history from inception to closure. in R Jewell \& $A B$ Fourie (eds), Proceedings of the 18th International Seminar on Paste and Thickened Tailings, Australian Centre for Geomechanics, Perth, 2015, pp. 13-41.

MICHALOWSKI, R.L.; CERMÁK, J. Triaxial compression of sand reinforced with fibers. Journal of Geotechnical and Geoenvironmental Engineering, New York, v.129, n.2, p.125-136, 2003.

MONTARDO, J.P. Comportamento mecânico de compósitos solo-cimentofibra: estudo do efeito das propriedades dos materiais constituintes. Porto 
Alegre, 1999. 130p. Dissertação (Mestrado em Engenharia) - Programa de PósGraduação em Engenharia Civil da UFRGS.

MONTARDO, J.P.; CONSOLI, N.C.; PRIETTO, P.D.M. Comportamento mecânico de compósitos solo-cimento-fibra: estudo do efeito das propriedades dos materiais constituintes. Solos e Rochas, São Paulo, ABMS/ABGE, v.24, n.3, p.191-209, 2002.

MOREL, J.C.; GOURC, J.P. Mechanical behaviour of sand reinforced with mesh elements. Geosynthetics International, Minnesota, v.4, n. 5, p.481-508, 1997.

MOTTA H.P.G. Comportamento de um rejeito de transição em centrífuga geotécnica. Rio de Janeiro, 2008. 152p. Dissertação (Mestrado em Engenharia) Programa de Pós-Graduação em Engenharia Civil da Universidade Federal do Rio de Janeiro.

MURTHY T.G., PREZZI M., SALGADO R. AND LOUKIDIS D. Undrained monotonic response of clean and silty sands. Géotechnique 57 (3), 2007, 273288

NATARAJ, M.S.; ADDULA, H.R.; MCMANIS, K.L. Strength and deformation characteristics of fiber reinforced soils. INTERNATIONAL SYMPOSIUM ON ENVIRONMENTAL GEOTECHNOLOGY, 3., San Diego, 1996. Proceedings. Pennsylvania: Technomic Publiching Co., Inc, v.1, p.826-835, 1996.

ORGANISMO DE EVALUACIÓN Y FISCALIZACIÓN AMBIENTAL OEFA (2018). https://www.oefa.gob.pe/noticias-institucionales/oefa-ordena-a-la-mineralincuna-medidas-administrativas-inmédiatas-para-evitar-mayor-afectacion-alambiente-y-a-la-poblacion-de-ancash. Data de aceso 23 de abril 2018.

PARKA T, TAN A. Enhanced performance of reinforced soil walls by the inclusion of short fiber. Geotext Geomembr 2005; 23:348-61.

PARODI M.A.; CASAGRANDE M.D.T.; CONSOLI N.; Comportamento de uma Areia Reforçada com Fibras de Polipropileno Submetida a Ensaios Triaxiais de Extensão. Rio de Janeiro, 2012. 101p. Dissertação (Mestrado em Engenharia) - Pontifícia Universidade Católica do Rio de Janeiro.

PEREIDA E.L. Estudo do potencial de liquefação de rejeitos de minério de ferro sob carregamento estático. Minas Gerais, 2005. 210f. Dissertação (Mestrado em Geotecnia) - Escola de Minas, Universidade Federal de Ouro Preto.

PRESOTTI, E. S. Influência do teor de ferro nos parâmetros de resistência de um rejeito de minério de ferro. Minas Gerais, 2002. 115 f. Dissertação (Mestrado em Geotecnia) - Escola de Minas, Universidade Federal de Ouro Preto.

RANJAN, G.R.; CHARAN, H.D. Probabilistic analysis of randomly distributed fiber- reinforced soil. Journal of Geotechnical Engineering, New York, v.122, n.6, p.419-426, 1996. 
REZENDE, V.A. Estudo do comportamento de barragem de rejeito arenoso alteada por montante. Ouro Preto, 2013. 181 f. Dissertação (Mestrado em Geotecnia) - Escola de Minas, Universidade Federal de Ouro Preto.

RIBEIRO I., ANGELIM R., GUIMARÃES R. Análise Granulométrica de Solos Tropicais com Granulômetro a Laser. Proc. Congresso Brasileiro de Mecânica dos Solos e Engenharia Geotécnica (COBRAMSEG), Goiânia , GO, Brazil (2014), paper, 9p.

RICO M., BENITO G., SALGUEIRO A., DIEZ-HERRERO A., PEREIRA H.G. Reported tailings dam failures. A review of the European incidents in the worldwide context. Journal of Hazardous Materials 152, 2008. pp 846-852.

SAMARCO (2015). Um ano do rompimento de Fundão. http://www.samarco.com/rompimento-da-barragem-de-fundao/. Data de aceso 23 de abril de 2018.

SANTONI R. L.; J. S. TINGLE; AND S. L. WEBSTER. Engineering Properties of Sand-Fiber Mixtures for Road Construction. J. Geotech Geoenviron Eng ASCE 2001; 27: 258-268.

SANTOS, A. G. Influência do teor de ferro na condutividade hidráulica saturada de um rejeito de minério de ferro. 2004. 191 f. Dissertação (Mestrado em Geotecnia) - Escola de Minas, Universidade Federal de Minas Gerais, Ouro Preto, 2004.

SHARMA V.; AND KUMAR A. Influence of relative density of soil on performance of fiber reinforced soil foundations. Geotex Geomembr 2017; 45: 499-507.

SHEWBRIDGE, E.; SITAR, N. Deformation characteristics of reinforced sand in direct shear. Journal of Geotechnical Engineering, New York, v.115, n.8, p.1134-1147, 1989.

SHEWBRIDGE, E.; SITAR, N. Deformation-based model for reinforced sand. Journal of Geotechnical Engineering, New York, v.116, n.7, p.1153-1170, 1990.

SITHARAM T.G., RAJU L., MURTHY B.R. Cyclic and monotonic undrained shear response of silty sand from Bhuj region in India. ISET Journal of Earthquake Technology, Paper No. 450, Vol. 41, No. 2-4, June-December 2004, pp. 249-260.

SILVA F.A. Materiais Compósitos Aplicados à Industria da Construção Civil. Notas de aula. Departamento de Engenharia Civil, Pontifícia Universidade Católica do Rio de Janeiro, 2014.

SILVEIRA M. Análise do Comportamento Mecânico e da Durabilidade em Compósitos de Areia Reforçada com Fibras Naturais de Curauá e Sisal. $148 \mathrm{f}$. Tese (Doutorado em Geotecnia) Departamento de Engenharia Civil, Pontifícia Universidade Católica do Rio de Janeiro, Rio de Janeiro, 2018. 
SOARES, L., ARNEZ, F.I., HENNIES, W.T. Major causes of accidents in tailing dam due to geological and geotechnical factors. In: Mine Planning and Equipment Selection - International Symposium, 2000, pp. 371-376.

SPINACÉ M., LAMBERT C., FERMOSELli K., DE PAOLI M. Characterization of lignocellulosic curaua fibres. Carbohydrate Polymers 77, 2009, pp. 47-53.

STAUFFER, S.D.; HOLTZ, R.D. Stress-strain and strength behavior of staple fiber and continuous filament-reinforced sand. Transportation Research Record, Washington, D.C., n.1474, p.82-95, 1996.

TARAZONA C.F. Estudo da alteração em laboratório de rejeitos de mineração de ferro para análise em longo prazo. Rio de Janeiro, 2015. 247p. Tese (Doutorado em Geotecnia). Departamento de Engenhara Civil, Universidade Federal do Rio de Janeiro.

TARAZONA C.F., BARBOSA, M.C., Comparação das Características Geotécnicas de Alguns Rejeitos de Mineração Brasileiros. Proc. Congresso Brasileiro de Geotecnia Ambiental (REGEO)/Geossintéticos, Belo Horizonte, MG, Brazil (2011), paper 4-219, 8p.

TAYLOR, G.D. Materials in construction. 2ed. London: Longman Scientific \& Technical, 284p., 1994.

TELLES A.C.M. Análise do comportamento de um rejeito de minério de ferro no estado de regime permanente. Rio de Janeiro, 2017. 126f. Dissertação (Mestrado em Engenharia). Departamento de Engenhara Civil - Universidade Federal do Rio de Janeiro.

TEODORO, J.M. Resistência ao cisalhamento de solos reforçados com fibras plásticas. São Paulo, 1999. 108f. Dissertação (Mestrado em Engenharia) - Escola de São Carlos/ USP.

TEODORO, J.M.; BUENO, B.S. Estudo do comportamento dos solos reforçados com fibras plásticas de polipropileno. CONGRESSO BRASILEIRO DE MECÂNICA DOS SOLOS E ENGENHARIA GEOTÉCNICA, 11, Brasília, 1998. Anais. v.2., p.1093-1100, 1998.

TINGLE M.; SANTONI R.; AND WEBSTER S. Full-Scale Field Tests of Discrete Fiber-Reinforced Sand. J Transp Eng 2002; 128: 9-16.

VERDUGO R. Seismic performance based-design of large earth and tailing dams. Performance-Based Design in Earthquake Geotechnical Engineering Kokusho, Tsukamoto \& Yoshimine (eds), 2009. Taylor \& Francis Group, London, ISBN 978-0-415-55614-9.

VICK. S. G. Planning, Design and Analysis of Tailing Dams. New York: John Wiley \& Sons, 1983. 
ULBRICH, L.A. Aspectos do comportamento mecânico de um solo reforçado com fibras. Porto Alegre, Tese Mestrado em Engenharia Civil, UFRGS, 122p., 1997.

U.S. GEOLOGICAL SURVEY, 2018. Mineral commodity summaries 2018: U.S. Geological Survey, 200 p., https://doi.org/10.3133/70194932. Data de accesso 23 de abril de 2018.

ZORNBERG, J. G. Discrete framework for limit equilibrium analysis of fiberreinforced soil. Géotechnique 2002; 52: 593-604. 
Apêndice

a) Rejeito de Minério de Ferro Drenado

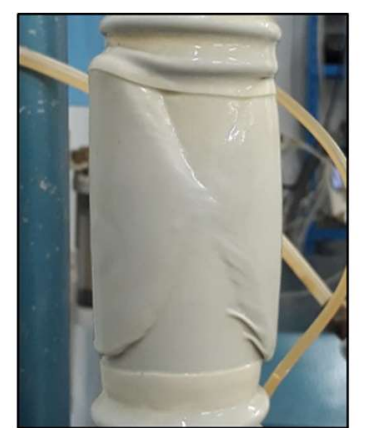

Fe-CD-50 kPa-SF

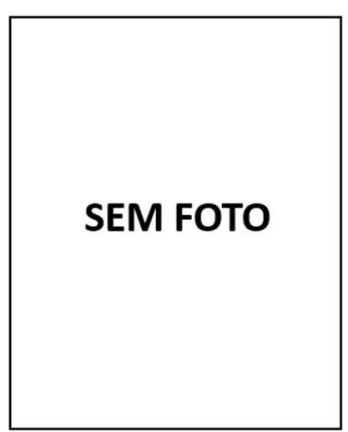

Fe-CD-50 kPa-CF

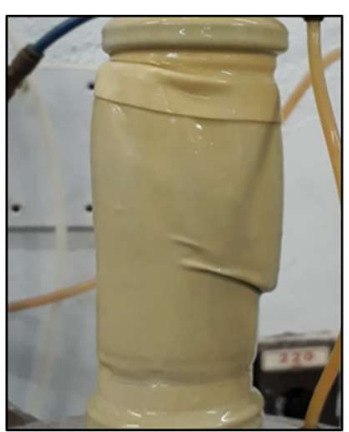

Fe-CD-100 kPa-SF

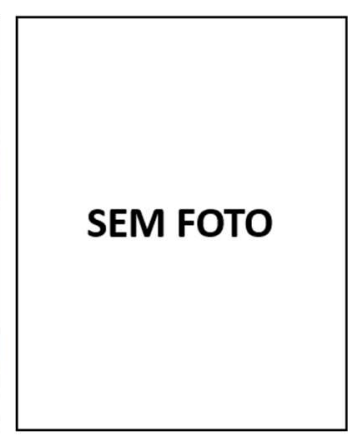

Fe-CD-100 kPa-CF
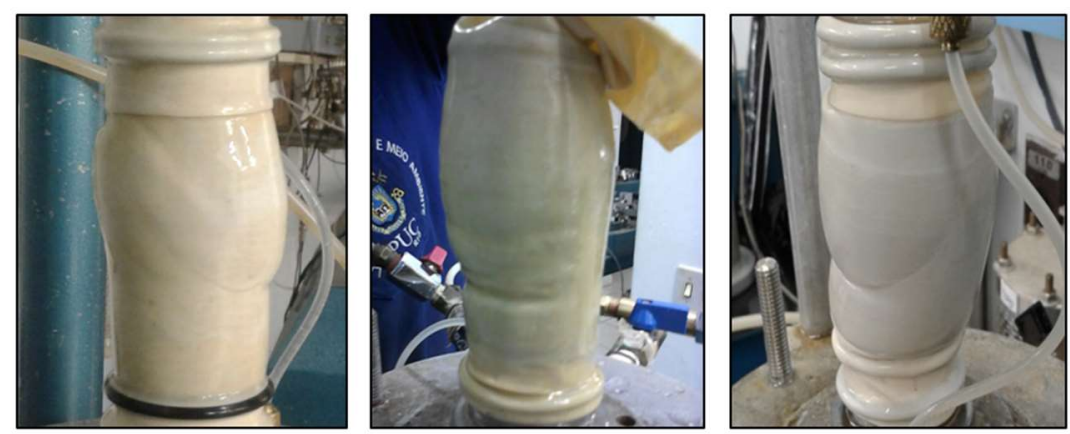

Fe-CD-200 kPa-SF

Fe-CD-200 kPa-CF

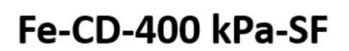

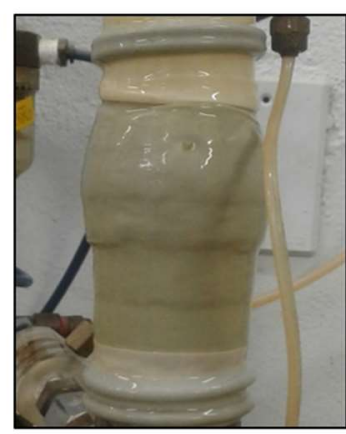

$\mathrm{Fe}-\mathrm{CD}-400 \mathrm{kPa}-\mathrm{CF}$

b) Rejeito de Minério de Ferro não Drenado

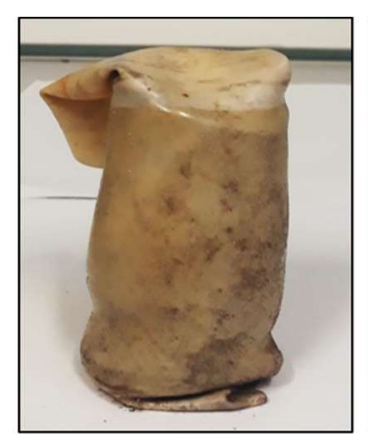

Fe-CU-50 kPa-SF

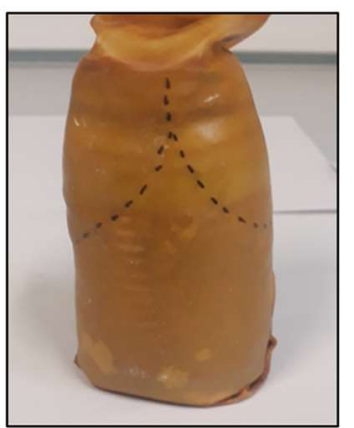

Fe-CU-200 kPa-SF

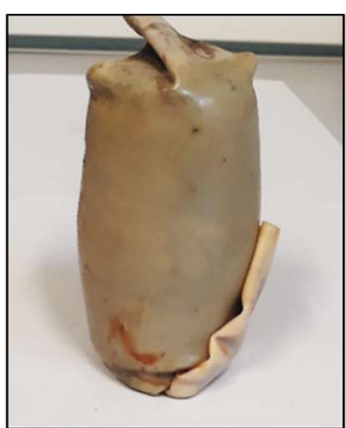

$\mathrm{Fe}-\mathrm{CU}-50 \mathrm{kPa}-\mathrm{CF}$

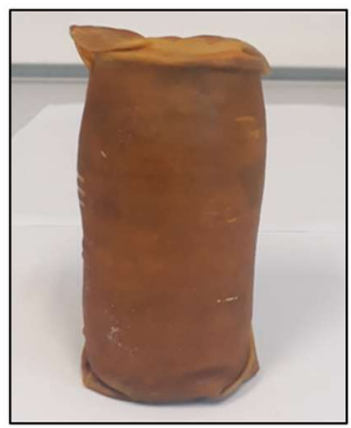

Fe-CU-200 kPa-CF

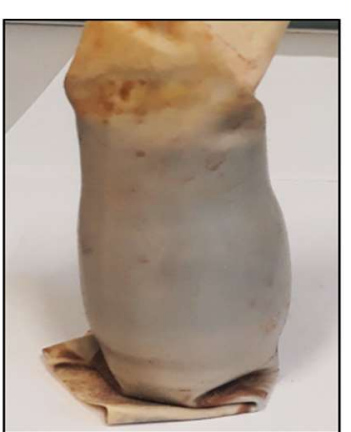

Fe-CU-100 kPa-SF
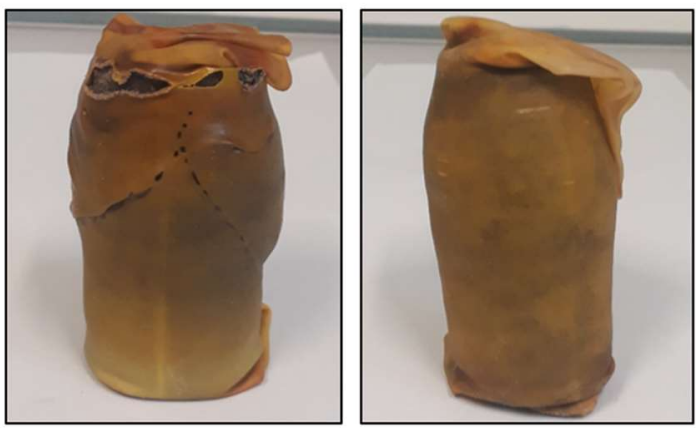

Fe-CU-400 kPa-SF Fe-CU-400 kPa-CF 
c) Rejeito de Minério de Ouro Drenado

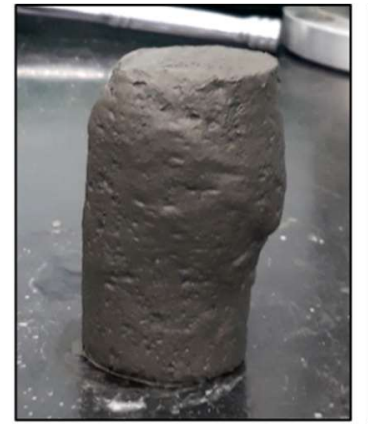

Au-CD-50 kPa-SF

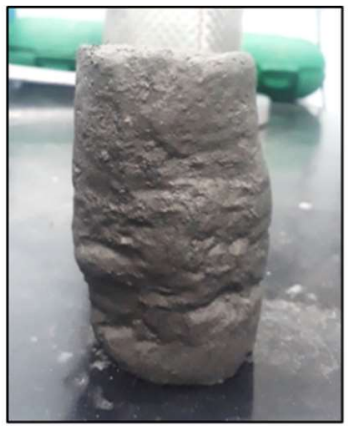

Au-CD-50 kPa-CF

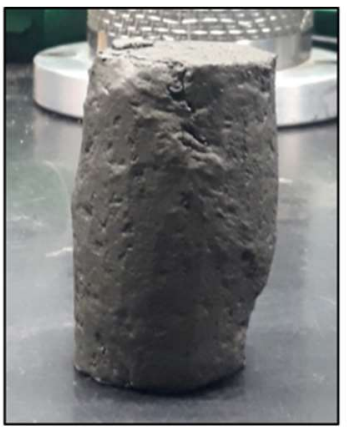

Au-CD-100 kPa-SF

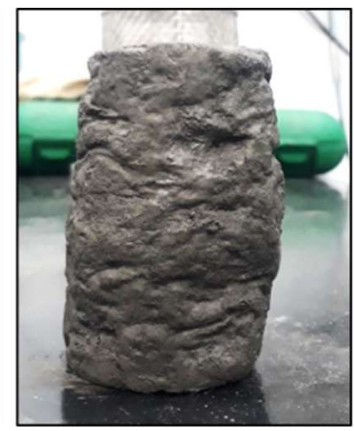

Au-CD-100 kPa-CF

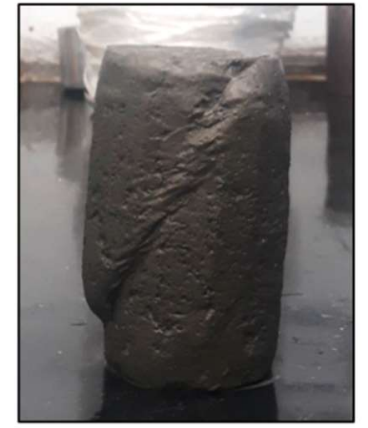

Au-CD-200 kPa-SF

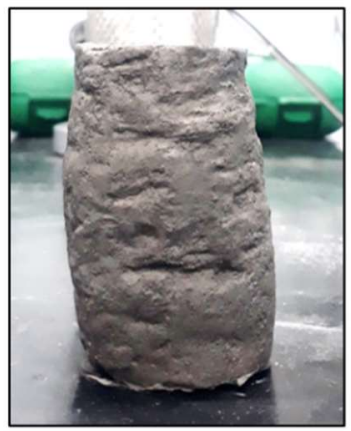

$\mathrm{Au}-\mathrm{CD}-200 \mathrm{kPa}-\mathrm{CF}$

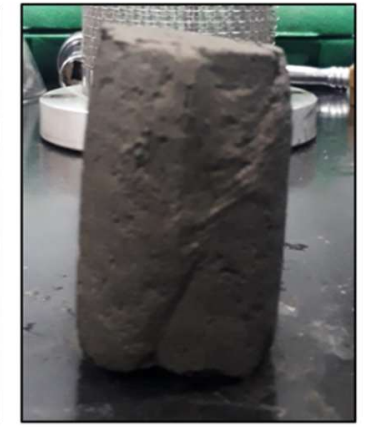

Au-CD-400 kPa-SF

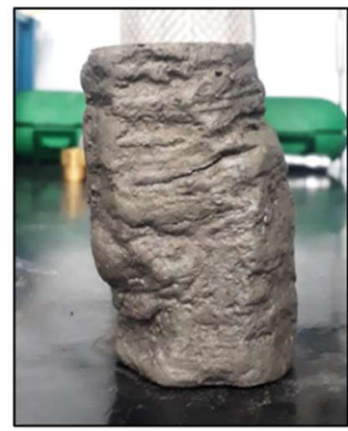

Au-CD-400 kPa-CF

d) Rejeito de Minério de Ouro não Drenado

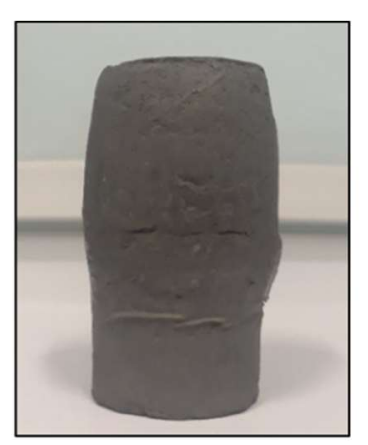

Au-CU-50 kPa-SF

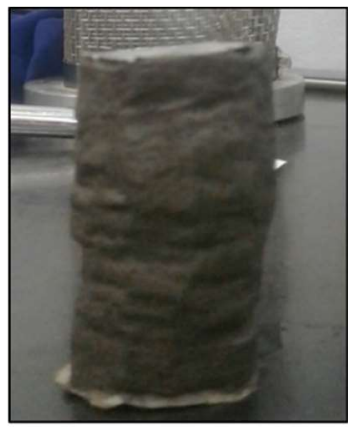

Au-CU-50 kPa-CF

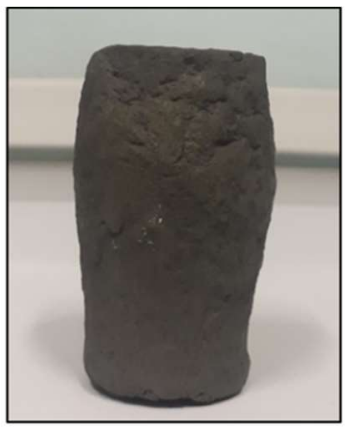

Au-CU-100 kPa-SF

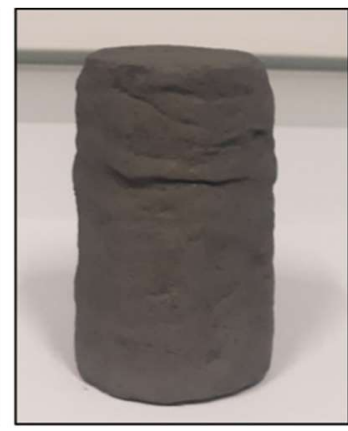

Au-CU-100 kPa-CF
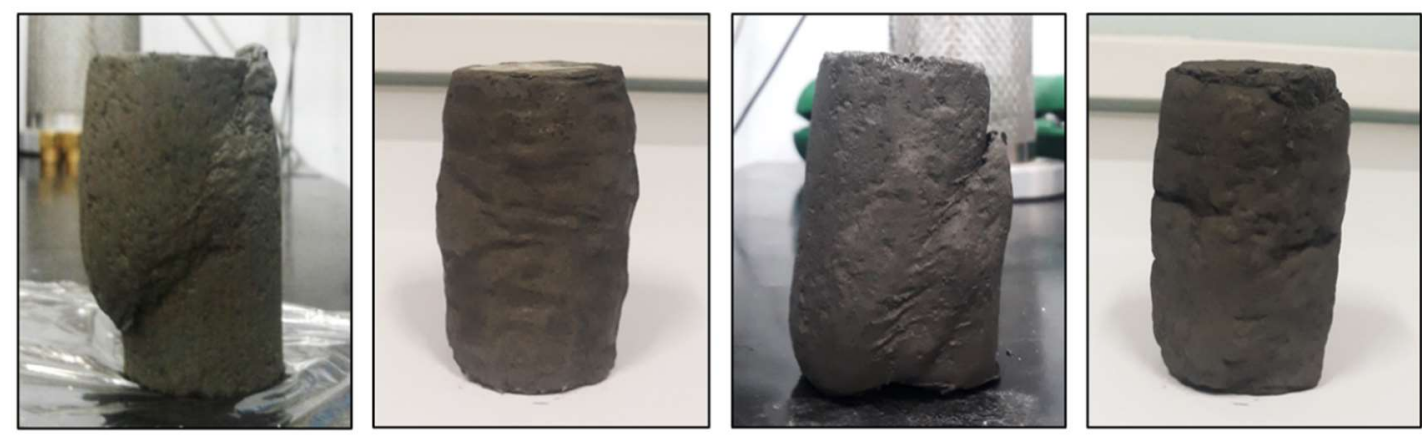

Au-CU-200 kPa-SF Au-CU-200 kPa-CF

Au-CU-400 kPa-SF Au-CU-400 kPa-CF 